\title{
Ash related problems with biomass combustion - application to co-firing in large scale boilers
}

\author{
Arthur Stam
}




\title{
ASH RELATED PROBLEMS WITH BIOMASS COMBUSTION - APPLICATION TO CO-FIRING IN LARGE SCALE BOILERS
}

\section{PROEFSCHRIFT}

\author{
ter verkrijging van \\ de graad van doctor aan de Universiteit Twente \\ op gezag van de Rector Magnificus, \\ prof. dr. T.T.M. Palstra, \\ volgens het besluit van het College voor Promoties, \\ in het openbaar te verdedigen \\ op 16 oktober 2020 om 12:45 uur \\ door \\ Arthur Frank STAM \\ Geboren te Nijmegen
}


Dit proefschrift is goedgekeurd door:

de promotor: Prof.dr.ir. G. Brem

Cover design: Franke Hoogerkamp, FrankeMargrete Grafisch Design

Printed by: PROEFSCHRIFTMAKEN

ISBN: $\quad 978-90-365-50277$

DOI: $\quad$ 10.3990/1.9789036550277, https://doi.org/10.3990/1.9789036550277

(C) 2020 Arthur Stam, Enschede, The Netherlands. All rights reserved. No parts of this thesis may be reproduced, stored in a retrieval system or transmitted in any form or by any means without permission of the author. Alle rechten voorbehouden. Niets uit deze uitgave mag worden vermenigvuldigd, in enige vorm of op enige wijze, zonder voorafgaande schriftelijke toestemming van de auteur. 
PROMOTIE COMMISSIE

Voorzitter/secretaris

Promotor:

Referee:

Leden: prof.dr.ir. H.F.J.M. Koopman

prof.dr.ir. G. Brem

dr.ir. A.J.A. Konings

prof.dr. S. Luding

prof.dr. S.R.A. Kersten

prof.dr.ir. W. de Jong

prof. J.E. Oakey

prof.dr.ir. T.H. van der Meer
University of Twente

University of Twente

Creasol

University of Twente

University of Twente

Delft University of Technology

Cranfield University

University of Twente 


\section{TABLE OF CONTENTS}

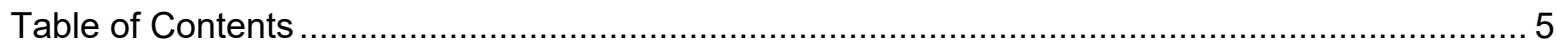

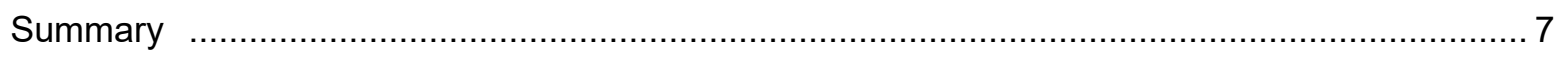

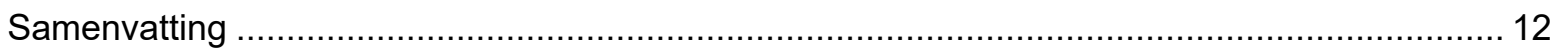

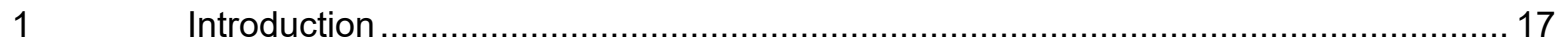

$1.1 \quad$ Reducing $\mathrm{CO}_{2}$ emissions from coal-fired power plants..................................... 17

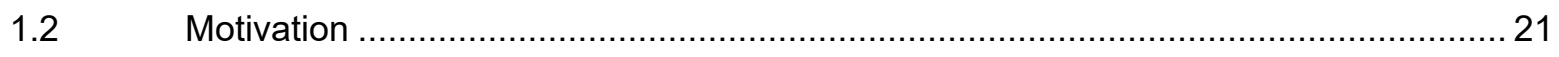

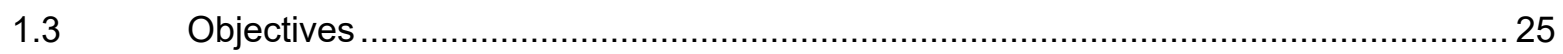

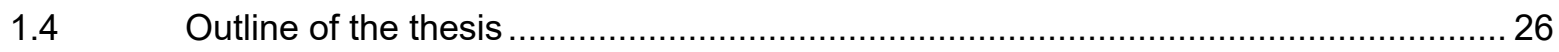

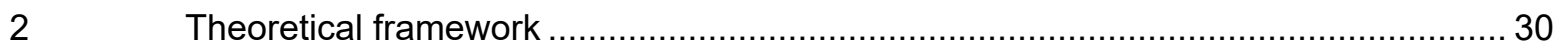

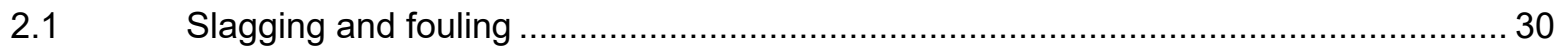

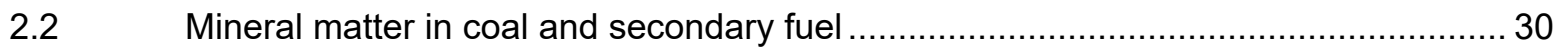

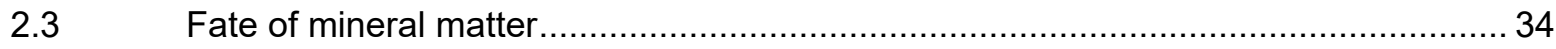

$2.4 \quad$ Deposition build-up and removal mechanisms .................................................. 51

3 Review of models and tools for slagging and fouling prediction for biomass co-firing 80

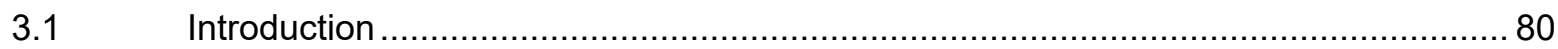

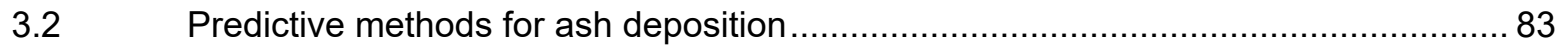

3.3 The on-line measurement and prediction of ash deposition ................................... 95

3.4 The application of ash deposition models and assessment methods to biomass co-

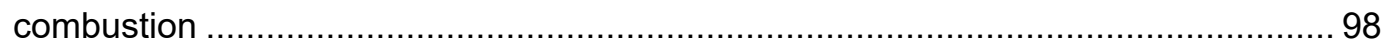

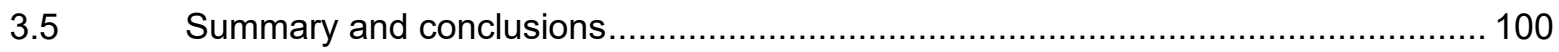

4 Superheater deposits in a pulverized coal-fired boiler co-firing wood or MBM ......... 105

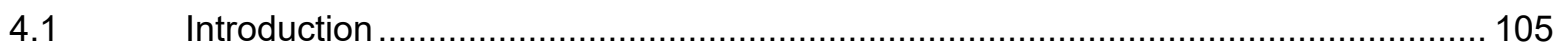

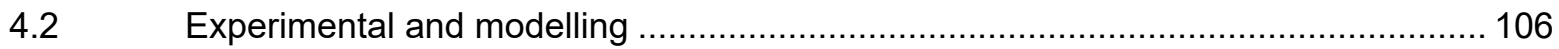

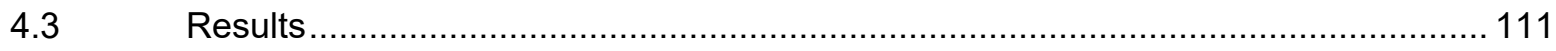

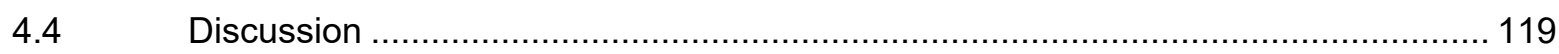

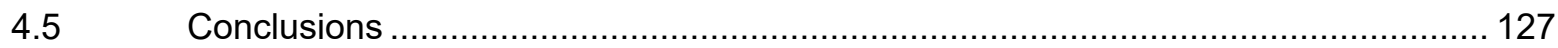

$5 \quad$ Fouling in coal-fired boilers: biomass co-firing, full conversion and use of additives - a

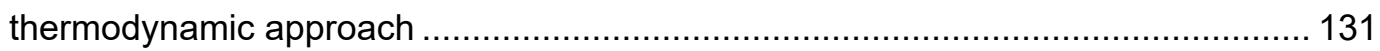

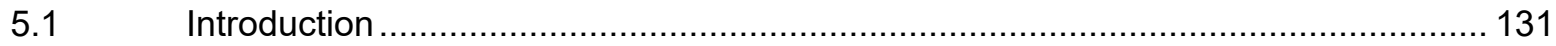

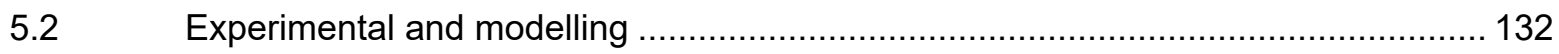

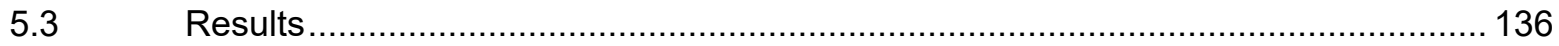

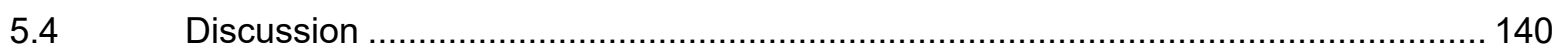

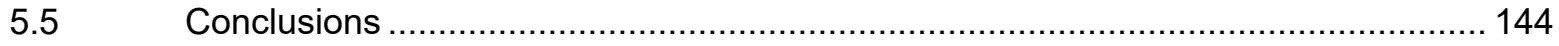


$6 \quad$ Superheater fouling in a BFB boiler firing wood-based fuel blends ...................... 147

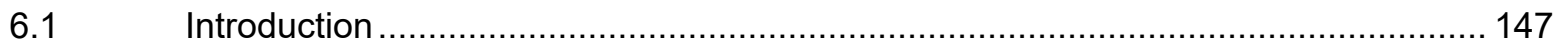

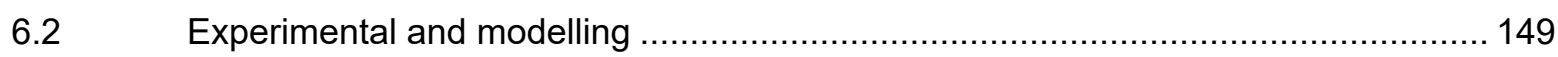

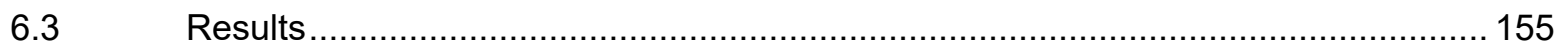

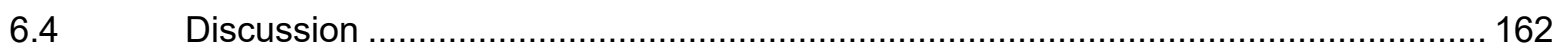

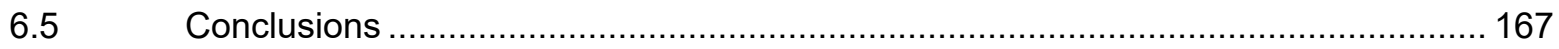

$7 \quad$ Chromium speciation in coal and biomass co-combustion products ..................... 171

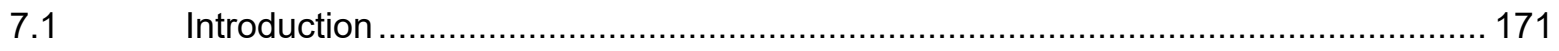

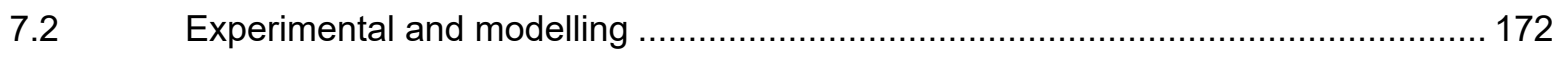

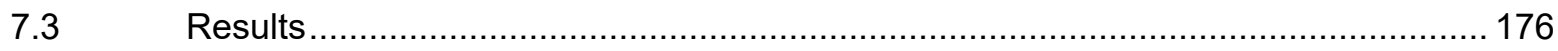

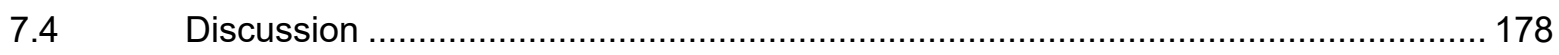

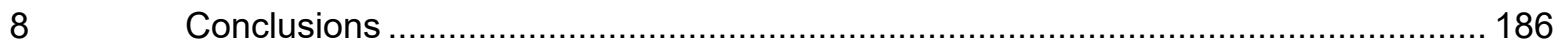

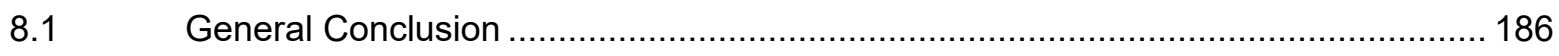

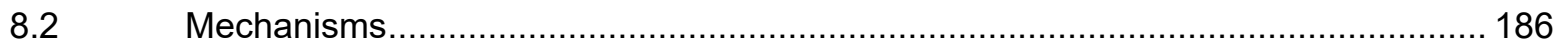

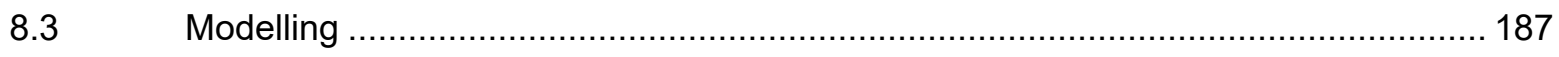

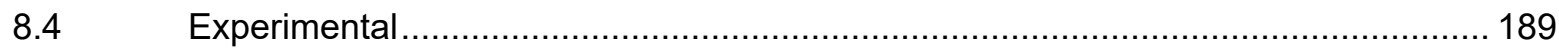

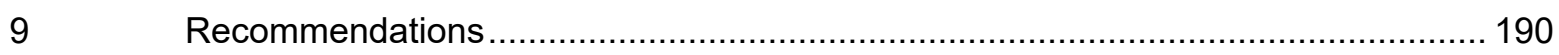

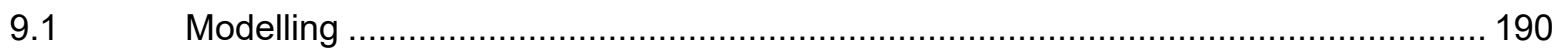

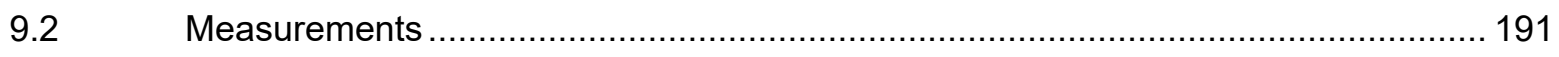

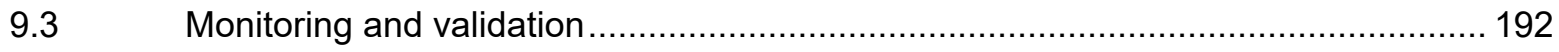

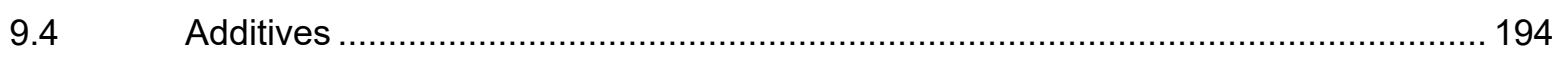

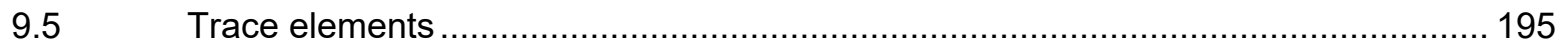

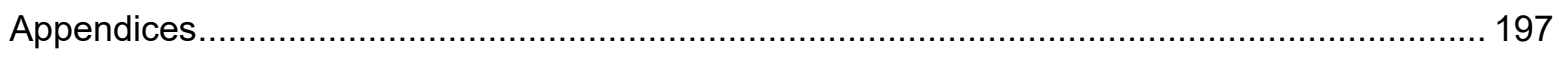

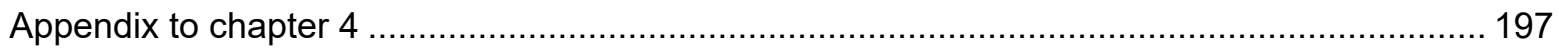

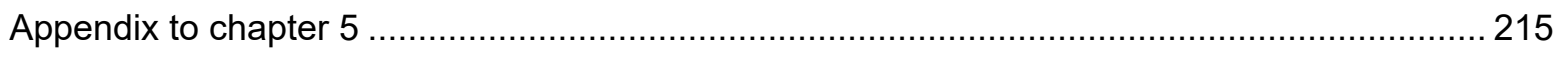

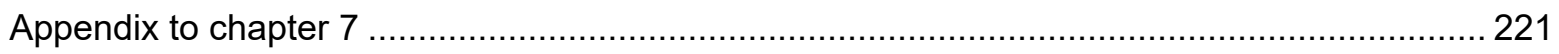

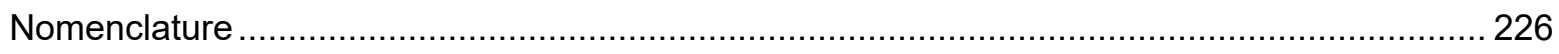

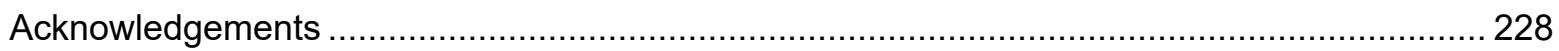

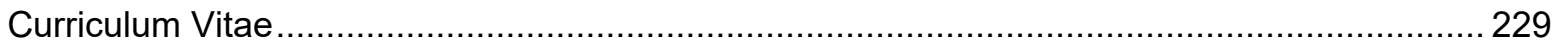

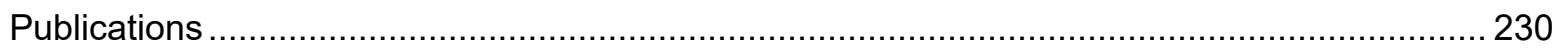




\section{SUMMARY}

Limiting future climate change will require substantial and sustained reductions of greenhouse gas emissions. As $\mathrm{CO}_{2}$-emissions from coal-fired power stations are highest per $\mathrm{kWh}$ of generated electricity of all forms of power generation, reduction of these emissions is of utmost importance. Amongst others, biomass co-firing is a technical solution that is commercially available and reasonably well established, and can be implemented fairly quickly against modest capital expenditure. For these reasons, it can be expected that biomass co-firing will continue to play a significant role in the achievement of global $\mathrm{CO}_{2}$ reduction. However, due to the physical and chemical properties of biomass, there are some technical issues with replacing coal by biomass. Operational problems as slagging and fouling ("ash deposition") can increase, and quality of ashes that are used in cement production could be compromised, specifically in regards to $\mathrm{Cr}(\mathrm{VI})$.

It has been shown that slagging increases with co-firing straw in pulverized coal boilers. Also in The Netherlands ash deposition problems have occurred in coal-fired boilers with co-firing biomass, however, it is yet unknown whether these problems can (partly) be attributed to the biomass. There is no long-term experience with biomass co-firing percentages of over $20 \%$ (on basis of energy input), and practical experiences are only based on limited demonstration tests. However, it is likely that biomass co-firing percentages will further be increased or that coal-fired power stations will be fully converted to fire only biomass to comply with government $\mathrm{CO}_{2}$ emission goals. The uncertainty about the impact of increased biomass co-firing rates, caused by a lack of understanding of the underlying physical and chemical phenomena, poses a risk on further implementation. The main goal of this thesis is to investigate how biomass co-firing will change ash deposition characteristics compared to pure coal firing. It has been found that cofiring of already small percentages of biomass (i.e. < $10 \%$ on basis of dry mass input) may directly impact slagging characteristics. However, the impact is very dependent on the type of biomass; for instance, slagging reduces with co-firing wood and increases with co-firing MBM-mix (Meat and Bone Meal). Model calculations show that fouling increases with co-firing biomass (at least, for the biomass investigated in this thesis being wood, MBM-mix and sheanut-mix). The increase in fouling is not linear with the co-firing rate. In general, fouling steeply increases above $80 \%$ co-firing, although for specific biomass types fouling may also increase significantly below this value.

The slagging characteristics are expected to change with co-firing biomass compared to firing only coal due to the difference in ash composition between biomass and coal. The most used biomass in The Netherlands is wood. Literature results on slagging with co-firing wood are limited and different outcomes of tests are not consistent. A few plants in The Netherlands co-fire MBM but practical results on ash deposition for co-firing MBM were not available. In this work, aircooled probe tests in full scale plants along with microscopic analyses of the deposits have been performed to gain insight in the formation of the depositing phases and to explain the 
mechanisms of deposit build-up. Thermodynamic modelling is applied to simulate the occurrence of molten phases and to explain the measured data. It has been found that:

- the bulk of the superheater deposits ("slagging") is formed by inertial impaction of molten particles. Thermophoresis and condensation (of alkalis) plays a negligible role;

- the slagging propensity with co-firing biomass compared to only firing coal depends both on the amount of the formed slag and the stickiness of the slag;

- the stickiness depends on concentration of network formers and modifiers in the slag. For example, the concentration of the network former $\mathrm{SiO}_{2}$ in the slag decreases with co-firing wood or MBM-mix and similarly, the concentration of the network modifier $\mathrm{CaO}$ increases with co-firing MBM-mix;

- deposition of molten Fe-O-S results from minerals in the coal ash and will decrease linearly with the biomass co-firing rate;

- the particles that are present in superheater deposits with co-firing MBM-mix and coal which are rich in $\mathrm{Ca}$ and $\mathrm{P}$, are formed due to collision of the relatively large bioapatite particles (present in bone material) with molten aluminosilicate particles, forming a Caand P-rich slag.

A slagging prediction model for co-firing biomass is required to support plant operators in selecting the fuel diet. Limited results have been published on modelling ash deposition for cofiring biomass with coal. An important aspect of such a model should be in how far chemical elements are available for reaction, "element availabilities". Some existing models are just based on fuel characterizations that not have been compared with actual element availabilities. And, other models are based on the concept of a reactive layer derived from lab-scale results that did not take into account the interaction of alkalis with aluminosilicate glass. A new modelling approach with element availability based on practical conditions has been developed and is presented in this thesis. The model is based on thermodynamic equilibrium. Thermodynamic calculations are suitable to predict the molten phases (slag and Fe-O-S melt) responsible for the bulk of the formed deposits.

Fouling (by molten alkali salts) may also change with increased biomass co-firing percentages because a) the potassium concentration in biomass fuel ash is - in general - higher compared to coal ash, b) during combustion, alkalis in biomass will generally volatize to a larger extent compared to coal and c) fouling in dedicated biomass boilers is a well-known problem. However, practical experience shows, that co-firing limited amounts of biomass does not increase deposition of molten salts and high-temperature corrosion compared to only coal firing. This can be explained by the fact that the maximum flue gas temperature in coal-fired boilers is higher and that aluminosilicates are present in coal ash. Alkalis will interact with these (partly molten) aluminosilicates, capturing them from the gas phase and prevent fouling. As such, coal ash and kaolinite (a coal ash constituent) are used as an additive to reduce fouling with biomass firing. This interaction will depend on the ratios of elements in the fuel. For example: an increased 
amount of water soluble $\mathrm{K}$ in fly ash (i.e. not in the slag) with an increased ratio of K:Si in the fuel was found previously in an entrained flow reactor study for co-combustion of coal and straw.

To gain more insight in the high temperature process $\left(>900{ }^{\circ} \mathrm{C}\right.$ ) of interaction between $\mathrm{K}, \mathrm{Na}$ and fuel ash more data have been collected from (co-) firing biomass in dedicated coal boilers. For this purpose an investigation has been conducted by a) investigating fly ashes generated with full-scale biomass co-firing experiments with Scanning Electron Microscopy (SEM) and b) simulating the behaviour of alkalis during combustion with thermodynamic equilibrium calculations. It has been found that alkali dissolution decreases with an increasing ratio of ( $\mathrm{CaO}$ $+\mathrm{MgO}$ ) to $\mathrm{SiO}_{2}$ in the aluminosilicate glass phase which, in its turn, increases with biomass cofiring ratio. Addition of $1-10 \mathrm{~g} / \mathrm{MJ}$ coal fly ash can mitigate fouling with firing only wood, MBMmix or sheanut-mix. Volatile alkalis that do not interact with aluminosilicates will condense downstream upon cooling of the flue gases and may cause fouling and high-temperature corrosion at flue gas temperatures of around $700{ }^{\circ} \mathrm{C}$ and below. Previously, it was also found that fouling and high-temperature corrosion in biomass-fired boilers are dependent on the $\mathrm{S}$ to $\mathrm{Cl}$ ratio and, as a rule of thumb, the $S$ to $\mathrm{Cl}$ ratio should be kept $>4$. The application of sulphurcontaining additives is based on increasing the $S$ to $\mathrm{Cl}$ ratio. Although the effect of elemental ratios has not been investigated for biomass co-firing, this rule of thumb is generally also practiced by operators of coal-fired power plants while co-firing biomass.

The effect of the elemental ratio of $\mathrm{K}, \mathrm{Na}, \mathrm{S}$ and $\mathrm{Cl}$ on the formation of molten alkali salts at low temperatures (below approximately $900{ }^{\circ} \mathrm{C}$ ) has also been investigated. This is done by thermodynamic calculations, simulating the chemistry during the combustion of coal and biomass mixtures, and the combustion of only biomass with the addition of ammonium sulphate $\left(\left(\mathrm{NH}_{4}\right)_{2} \mathrm{SO}_{4}\right)$. It has been found that the formation of molten alkali salts depends on both the $\mathrm{S}$ to $\mathrm{Cl}$ ratio and the $\mathrm{K}$ to $\mathrm{Na}$ ratio: in equilibrium, a molten salt forms with $\mathrm{S}: \mathrm{Cl} \leq 1.2$ if $\mathrm{K}: \mathrm{Na}>10$, with $\mathrm{S}: \mathrm{Cl} \leq 2.1$ if $2.4<\mathrm{K}: \mathrm{Na}<4.7$ and with $\mathrm{S}: \mathrm{Cl} \leq 3.5$ if $\mathrm{K}: \mathrm{Na}=1$. The $\mathrm{S}: \mathrm{Cl}$ ratio decreases with increasing biomass co-firing rate. Thermodynamic calculations show that the addition of $1 \mathrm{~g} / \mathrm{MJ}$ ammonium sulphate can fully mitigate fouling with firing sheanut-mix that contains relatively little $\mathrm{Na}$, and can lower fouling with firing wood up to a flue gas temperature of $700{ }^{\circ} \mathrm{C}$. However, it will increase fouling with wood above $700{ }^{\circ} \mathrm{C}$. Fouling with firing MBM-mix is not influenced by adding ammonium sulphate since it is already a sulphur-rich fuel mix.

Fluidized bed boilers are designed to accept a wide range of fuels while in general fly ashes are not re-used. A number of (economically attractive) residual streams can meet the acceptance criteria for fluidized bed boiler, but can be problematic in terms of fouling. Understanding of the fouling behaviour of such fuels and developing predictive models is of great interest. Full scale deposition tests using air-cooled probes and microscopic analyses of the deposits are carried out to get insight in the formation of the depositing phases and to explain the mechanisms of deposit build-up. Tests were performed for a number of locally available wood-based fuel blends fired in the bubbling fluidized bed boiler in Cuijk, The Netherlands. The results show that superheater 
fouling deposits are rich in $\mathrm{Ca}, \mathrm{K}$ and $\mathrm{S}$. The occurrence of alkalis can be explained by gaseous alkalis that condense as small particles in the flue gas or in the boundary layer above the tube or deposit surface. Subsequently the small particle may be transported to the tube or deposit surface by thermophoresis, and later, by eddy diffusion and Brownian diffusion. The alkalis can also condense homogeneously on or in the deposit. Whether $\mathrm{KCl}$ has deposited and is later sulphatized, or that $\mathrm{K}_{2} \mathrm{SO}_{4}$ has deposited, or a combination of the two, could not be established. Sintering occurs by sulphation of the $\mathrm{Ca}$ present in the deposit (in case of coarse particles deposited by inertial impaction) and by liquid flow of molten K-Na-S-Cl salt. However, if the salt melt is mixed with $\mathrm{Ca}$, the melting point will increase, so this effect will occur only where the Cacontent is low or when $\mathrm{Ca}$ is chemically inert (e.g. as calcium silicate or slag). A prediction model for the specific fuel blends used in the BFB in Cuijk is not available. Based on experience with fouling in black liquor recovery boilers, the fouling indicator in some models relates to the melt percentage of total ash. The reasoning is that ash particles should contain a certain amount of liquid melt to deposit. The melt fraction may, however, not be evenly distributed amongst the ash particles. Therefore, another approach has been taken in this thesis whereby the fouling indicator is based on the extent to which a melt is present at the deposit temperature (i.e. temperature range between metal surface and local flue gas temperature). The reasoning is that if the deposit surface is sticky, impacting particles can stick. A comparison of modelling results based on both approaches showed that the amount of molten salt as predicted by equilibrium is a better predictor for deposition propensity. It is predicted that deposition rates in BFB boilers depend on the composition of the fuel blend. The fuel blends considered in this work are mentioned in order of increasing predicted fouling propensity: 1) $100 \%$ wood chips, 2) $39 \%$ demolition wood, $39 \%$ wood cuttings, $6 \%$ compost overflow, $7 \%$ paper sludge, $9 \%$ roadside grass, 3) $6 \%$ wood chips, $68 \%$ wood cuttings, $9 \%$ compost overflow, $18 \%$ paper sludge and 4 ) $8 \%$ wood chips, $39 \%$ demolition wood, $53 \%$ wood cuttings. The shares in the fuel blend are based on mass input (as received). The results are in line with operational experience and air-cooled probe testing results.

Aside from the effect of co-firing biomass on operational ash related problems, co-firing biomass may have an influence on the environmental properties of fly ash. In The Netherlands, this is of particular importance, since fly ash is re-used for concrete at large scale. As reported earlier, biomass co-firing of up to $15 \%$ (dry mass input) will not greatly influence the fly ash composition and environmental properties of co-firing fly ashes are equivalent to coal fly ash. However, not only the concentration of (trace) elements is important, but also their speciation (e.g. with respect to oxidation state and/or molecular structure). This is particularly true for chromium, since $\mathrm{Cr}(\mathrm{VI})$ is leachable whereas $\mathrm{Cr}(\mathrm{III})$ is not so, and $\mathrm{Cr}(\mathrm{VI})$ is carcinogenic and more toxic than $\mathrm{Cr}(\mathrm{III})$. Determination of the chromium oxidation states in fly ash requires a technique with a detection limit in the ppm range and such a technique should not require extraction from the solid by dissolution, being a significant source of uncertainty and error. One such technique is X-ray absorption fine-structure (XAFS) spectroscopy. This technique has been applied, along with and Relative Enrichment factors to fly ashes resulting from coal firing and biomass co-firing. By combining the results from analyses and thermodynamic calculations, a better understanding of 
the formation process of chromium speciation is gained. $\mathrm{Cr}$ bound in coal as illite or III-valent oxide will be incorporated in the aluminosilicate melt, or will remain unchanged during combustion, respectively. In both cases, $\mathrm{Cr}$ in fly ash will occur as non-leachable $\mathrm{Cr}(\mathrm{III})$. Organically bound $\mathrm{Cr}$ in coal or biomass may vaporize during combustion and with sufficient oxygen, occur as $\mathrm{CrO}_{3}(\mathrm{~g})$ in the flue gas. Upon cooling, $\mathrm{CrO}_{3}(\mathrm{~g})$ can be stabilized through a surface reaction at fly ash particles with a e.g. $\mathrm{Ca}, \mathrm{Mg}, \mathrm{K}, \mathrm{Na}$ or $\mathrm{Fe}$, as leachable $\mathrm{Cr}(\mathrm{VI})$; in case $\mathrm{CrO}_{3}(\mathrm{~g})$ reacts with e.g. $\mathrm{Ba}$, the $\mathrm{Cr}$ will occur in fly ash as non-leachable $\mathrm{Cr}(\mathrm{VI})$. Without sufficient oxygen, $\mathrm{CrO}_{3}(\mathrm{~g})$ may react to lower valence oxides and occur in fly ash as $\mathrm{Cr}_{2} \mathrm{O}_{3}(\mathrm{~s})$. 


\section{SAMENVATTING}

De uitstoot van broeikasgassen zal substantieel en blijvend verminderd moeten worden om toekomstige klimaatverandering te beperken. Omdat van alle vormen van elektriciteitsopwekking de $\mathrm{CO}_{2}$-emissies van kolengestookte centrales het hoogste zijn per kWh opgewekte elektriciteit, is de vermindering van die emissies van het hoogste belang. Één van de technische oplossingen is het meestoken van biomassa; een oplossing die commercieel beschikbaar is, redelijk vaak wordt toegepast en die vrij snel kan worden geïmplementeerd waarbij investeringskosten beperkt blijven. Daarom is het te verwachten dat het meestoken van biomassa een belangrijke rol zal blijven spelen bij het realiseren van mondiale $\mathrm{CO}_{2}$-emissiereductie. Echter, de fysische en chemische eigenschappen van biomassa leveren wel enkele technische aandachtspunten op wanneer kolen door biomassa vervangen worden. Bedrijfsvoeringproblemen zoals verslakking en vervuiling ("asafzettingen") kunnen toenemen, en de kwaliteit van kolenas dat wordt gebruikt voor cementproductie kan in het geding komen, specifiek met betrekking tot de vorming van $\mathrm{Cr}(\mathrm{VI})$.

Het is gebleken dat verslakking toeneemt bij het meestoken van stro in poederkoolgestookte ketels. Ook in Nederland zijn asafzettingsproblemen opgetreden in kolengestookte ketels waar biomassa werd meegestookt. Echter, het is onduidelijk of deze problemen al dan niet gedeeltelijk kunnen worden herleid tot de biomassa. $\mathrm{Er}$ is geen langdurige ervaring met meestookpercentages boven de $20 \%$ (op basis van energie-inhoud) en de praktische ervaring met dergelijke hogere percentages is gebaseerd op beperkte demonstratieproeven. Het is echter niet onwaarschijnlijk dat biomassameestookpercentages verder verhoogd worden en dat kolengestookte centrales volledig worden omgebouwd tot biomassagestookte centrales om de $\mathrm{CO}_{2}$-emissiedoelstellingen van de overheid te behalen. De onzekerheid over de effecten van verhoogde meestookpercentages, veroorzaakt door een gebrek aan begrip van de onderliggende fysica en chemie, vormt een risico voor verdere implementatie van het meestoken van biomassa.

Het belangrijkste doel van deze studie is om te onderzoeken hoe het meestoken van biomassa de asafzetting beïnvloedt ten opzichte van kolen stoken. Één van de bevindingen is dat het meestoken van lage percentages biomassa (d.w.z. minder dan 10\% op basis van droge massa) verslakking kan beïnvloeden. Dit is echter sterk afhankelijk van het type biomassa; verslakking neemt bijvoorbeeld af bij het meestoken van hout en neemt toe bij het meestoken van MBM-mix ("Meat and Bone Meal", ofwel "diermeel"). Modelberekeningen laten zien dat vervuiling toeneemt met het meestoken van biomassa (ten minste, voor de biomassa's die in deze studie onderzocht zijn, te weten hout, MBM-mix en sheanut-mix). De toename van vervuiling is niet lineair met het meestookpercentage. In het algemeen neemt vervuiling sterk toe boven $80 \%$ biomassa, alhoewel voor specifieke soorten biomassa deze toename al ver onder dat percentage plaatsvindt. 
Door het verschil in assamenstelling wordt verwacht dat het verslakkingsproces verandert als gevolg van biomassa meestoken in vergelijking met alleen kolen stoken. De biomassa die in Nederland grootschalig wordt ingezet is hout. Resultaten uit de literatuur over verslakking bij hout meestoken zijn beperkt en de verschillende testresultaten zijn niet consistent. In een beperkt aantal centrales is / wordt MBM meegestookt maar praktische resultaten van asafzettingen bij het meestoken van MBM zijn niet beschikbaar. In dit onderzoek zijn proeven in commerciele installaties uitgevoerd met luchtgekoelde sondes in combinatie met microscopische analyses van de afzettingen om inzicht te krijgen in de vorming van de afgezette fasen en om de opbouwmechanismen te verklaren. Thermodynamische modellering is toegepast om het ontstaan van (gesmolten) fasen te simuleren en de meetdata te verklaren. De bevindingen zijn:

- De bulk van de afzettingen op oververhitters ("verslakking") wordt gevormd door 'inertial impaction' (botsing doordat een deeltje vanwege zijn traagheid de stroomlijnen om een warmtewisselaar niet volgt) van gesmolten deeltjes. Thermophorese en condensatie (van alkaliverbindingen) spelen een verwaarloosbare rol;

- De neiging tot verslakking bij biomassa meestoken in vergelijken tot kolen stoken hangt af van de gevormde hoeveelheid slak en de plakkerigheid van de slak;

- De plakkerigheid hangt af van de concentratie van netwerkvormers en - modificators in de slak. Als voorbeeld: de concentratie in de slak van netwerkvormer $\mathrm{SiO}_{2}$ neemt af met zowel meestoken van hout als MBM-mix en de concentratie van de netwerkmodificator $\mathrm{CaO}$ neemt toe met het meestoken van MBM-mix;

- Afzetting van gesmolten Fe-O-S is het gevolg van de aanwezigheid van mineralen zoals pyriet in de kolenas en neemt lineair af met het biomassa meestookpercentage;

- De deeltjes die aanwezig zijn in afzettingen op oververhitters bij het meestoken van MBM-mix met kolen die rijk zijn aan $\mathrm{Ca}$ en $\mathrm{P}$, worden gevormd door botsing van de relatief grote bio-apatiet deeltjes (aanwezig in botten) met gesmolten aluminiumsilicaat deeltjes waarbij zich een Ca- en P-rijke slak vormt.

Om de beheerders van centrales te ondersteunen bij het selecteren van een brandstofmengsel is een voorspellend model voor verslakking bij biomassa meestoken nodig. Een beperkte hoeveelheid resultaten is in het verleden gepubliceerd over het modelleren van asafzettingen bij het meestoken van biomassa met kolen. Een belangrijk aspect van zo'n model zou moeten zijn in hoeverre chemische elementen ook daadwerkelijk beschikbaar zijn voor de reactie, "elementbeschikbaarheden". Enkele bestaande modellen zijn alleen gebaseerd op brandstofkarakterisering die niet zijn vergeleken met werkelijke elementbeschikbaarheden. Andere modellen zijn gebaseerd op het concept van een reactieve laag die is afgeleid van labschaal resultaten waarbij de interactie tussen alkali-elementen met de aluminosilicaat glasfase niet is betrokken. In deze studie is een nieuwe modelleringsaanpak met elementbeschikbaarheid gebaseerd op werkelijke condities ontwikkeld en toegepast. Het model is gebaseerd op een zogenaamd thermodynamisch evenwicht. Thermodynamische berekeningen zijn geschikt om de gesmolten fasen (slak en Fe-O-S smelt) te voorspellen, die verantwoordelijke zijn voor de bulk van de gevormde afzettingen. 
Met een toename van het biomassa meestookpercentage kan ook de vervuiling (door gesmolten alkalizouten) veranderen doordat in vergelijking met kolen a) de concentratie kalium in biomassa as over het algemeen hoger is en b) tijdens de verbranding van de biomassa de alkaliën in hogere mate vervluchtigen. Overigens is vervuiling in biomassagestookte ketels een bekend probleem. Praktische ervaring laat echter zien dat het meestoken van beperkte hoeveelheden biomassa in vergelijking met kolen stoken niet tot een toename van gesmolten zoutafzettingen (en hoge-temperatuur corrosie) leidt. Dit wordt verklaard vanuit het feit dat in kolengestookte centrales de maximale rookgastemperatuur hoger is dan in biomassa gestookte centrales en omdat er aluminiumsilicaten aanwezig zijn in kolenas. Er vindt interactie plaats tussen alkaliën en (gedeeltelijk gesmolten) aluminiumsilicaten, waarbij de alkaliën worden afgevangen uit de gasfase en vervuiling wordt voorkomen. Om deze reden worden kolenvliegas en kaoliniet (een bestanddeel van kolenas) gebruikt als additief om vervuiling bij biomassaverbranding te reduceren. De mate van interactie hangt af van de verhoudingen van elementen in de brandstof. Bij een eerder uitgevoerde studie over meestoken van stro met kolen werd bijvoorbeeld een toename van water-oplosbaar kalium gevonden in de vliegas (d.w.z. niet zijnde de glasfase) bij een toenemende verhouding van $\mathrm{K}: \mathrm{Si}$ in de brandstof.

Om meer inzicht te krijgen in het hoge-temperatuurproces $\left(>900{ }^{\circ} \mathrm{C}\right)$ van interactie tussen kalium, natrium en as in de brandstof, is data verzameld van het meestoken van biomassa in kolengestookte ketels. Hiertoe is onderzoek verricht a) aan vliegassen van biomassa meestookexperimenten in commerciële installaties met REM (Raster Electronen Microscopie) en b) door simulatie van het gedrag van alkaliën tijdens de verbranding via thermodynamische evenwichtsberekeningen. Geconcludeerd wordt dat het oplossen van alkaliën in de glasfase afneemt met een toenemende verhouding $(\mathrm{CaO}+\mathrm{MgO})$ tot $\mathrm{SiO}_{2}$ in de aluminiumsilicaat glasfase; deze verhouding neemt toe met het meestookpercentage. Het toevoegen van $1-10$ g/MJ kolenvliegas kan vervuiling voorkomen bij het meestoken van hout, MBM-mix en sheanutmix. Vluchtige alkaliën, die geen interactie aangaan met aluminiumsilicaat condenseren stroomafwaarts (in de tweede trek) bij het afkoelen van de rookgassen, kunnen vervuiling en hoge-temperatuurcorrosie veroorzaken bij rookgassen van rond de $700{ }^{\circ} \mathrm{C}$ en kouder. Uit eerder onderzoek is gebleken dat vervuiling en hoge-temperatuurcorrosie in biomassa gestookte ketels afhankelijk zijn van de zwavel-chloor verhouding en als vuistregel wordt aangehouden deze verhouding boven de 4 te houden om corrosie te voorkomen. Het toepassen van zwavelhoudende additieven is gebaseerd op het verhogen van de zwavel-chloorverhouding. Hoewel het effect van het toepassen van deze verhouding niet is onderzocht voor biomassa meestoken, wordt de vuistregel breed toegepast door bedrijvers van kolengestookte centrales waar biomassa wordt meegestookt.

Het effect van de verhouding van de elementen kalium, natrium, zwavel en chloor op de vorming van gesmolten alkalizouten bij lage temperaturen (beneden ongeveer $900{ }^{\circ} \mathrm{C}$ ) is in deze studie onderzocht. Dit is gedaan via thermodynamische berekeningen waarbij de chemie tijdens verbranding van het mengsel van kolen en biomassa is gesimuleerd, als ook voor de 
verbranding van alleen biomassa met toevoeging van ammoniumsulfaat $\left(\left(\mathrm{NH}_{4}\right)_{2} \mathrm{SO}_{4}\right)$. Er kan worden geconcludeerd dat de vorming van gesmolten alkalizouten afhangt van zowel de zwavelchloor verhouding als de verhouding kalium-natrium. In evenwicht vormt zich een zoutsmelt bij $\mathrm{S}: \mathrm{Cl} \leq 1.2$ als $\mathrm{K}: \mathrm{Na}>10$, bij $\mathrm{S}: \mathrm{Cl} \leq 2.1$ als $2.4<\mathrm{K}: \mathrm{Na}<4.7$ en bij $\mathrm{S}: \mathrm{Cl} \leq 3.5$ als $\mathrm{K}: \mathrm{Na}=1$. De zwavel-chloor verhouding neemt af bij een toenemend biomassa meestookpercentage. Thermodynamische berekeningen laten zien dat door het toevoegen van $1 \mathrm{~g} / \mathrm{MJ}$ ammoniumsulfaat, de vervuiling tijdens het meestoken van sheanut-mix (hetgeen relatief weinig natrium bevat) volledig onderdrukt kan worden en dat de vervuiling kan verminderen bij het meestoken van hout bij rookgastemperaturen boven $700{ }^{\circ} \mathrm{C}$. Vervuiling bij het stoken van MBMmix wordt niet beïnvloed door het toevoegen van ammoniumsulfaat aangezien dit al een zwavelrijke brandstofmix is.

Wervelbedketels zijn ontworpen om een breed palet aan brandstoffen te kunnen verstoken. alhoewel de vliegassen veelal niet worden hergebruikt. Diverse (economisch aantrekkelijke) reststromen voldoen weliswaar aan de acceptatiecriteria voor wervelbedketels, maar kunnen problematische vervuiling veroorzaken. Het begrijpen van het vervuilingsgedrag van dergelijke brandstoffen en het ontwikkelen van voorspellende modellen is van groot belang. Proeven op commerciële schaal met luchtgekoelde sondes om afzettingen te verzamelen zijn uitgevoerd in combinatie met microscopische analyses van de afzettingen met als doel inzicht te verkrijgen in welke fasen de stoffen zich afzetten en om de mechanismen van de opbouw van afzettingen te verklaren. Testen zijn uitgevoerd met enkele lokaal beschikbare hout-gebaseerde brandstofmengels die zijn verstookt in de stationaire wervelbedketel ("bubbling fluidized bed", BFB) in Cuijk, Nederland. Uit de resultaten blijkt dat afzettingen op oververhitters rijk zijn aan calcium, kalium en zwavel. Het voorkomen van alkaliën wordt verklaard uit de condensatie van kleine deeltjes uit het rookgas, al dan niet in de grenslaag rondom de oververhitter, gevolgd door een transport naar het pijpoppervlak door thermophorese en in geval van een verder ontwikkelde afzetting door eddy diffusie en Brownse diffusie. De alkaliën kunnen ook direct condenseren op of in de afzetting. Of kaliumchloride zich heeft afgezet en later is gesulfateerd, of dat zich kaliumsulfaat heeft afgezet, of dat beide hebben plaatsgevonden, kon niet worden vastgesteld. De afzettingen sinteren door sulfatering van calcium dat aanwezig is in de afzetting (in geval van grovere deeltjes door 'inertial impaction') en door 'liquid flow' van gesmolten $\mathrm{K}-\mathrm{Na}-\mathrm{SO}_{4}-\mathrm{Cl}$ zout. Door de aanwezigheid van calcium neemt de smelttemperatuur van de zoutfase toe, dus 'liquid flow' treedt alleen dan op als de calcium concentratie laag is of wanneer het aanwezige calcium chemisch inert is (bijvoorbeeld als calciumsilicaat of in slak). Een voorspellend model voor de specifieke brandstofmengsels toegepast in de BFB in Cuijk is niet beschikbaar. Op basis van ervaring met vervuiling in 'black liquor recovery boilers' wordt de vervuilingsindicator gerelateerd aan het percentage gesmolten as. De redenering is dat as deeltjes een zekere hoeveelheid vloeibare smelt moeten bevatten om zich af te kunnen zetten. De smeltfractie hoeft echter niet homogeen verdeeld te zijn over de as deeltjes. Daarom is in deze studie een andere benadering gekozen waarbij de vervuilingsindicator gebaseerd is op de mate waarin een smelt aanwezig is bij de afzettingstemperatuur (d.w.z. het temperatuursinterval tussen 
metaaloppervlaktetemperatuur en lokale rookgastemperatuur). De redenering hierachter is dat wanneer het oppervlak van een afzetting plakkerig is, de daarop botsende deeltjes kunnen plakken. Volgens de modelvoorspellingen hangt de afzettingssnelheid in BFB ketels af van de brandstofsamenstelling. De in dit werk beschouwde brandstofmengsels genoemd in toenemende neiging tot vervuiling zijn: 1) $100 \%$ hout 'chips', 2) $39 \%$ sloophout, $39 \%$ snoeihout, $6 \%$ compostoverloop, $7 \%$ papierslib en $9 \%$ bermgras, 3) $6 \%$ hout 'chips', $68 \%$ snoeiafval, $9 \%$ compostoverloop en $18 \%$ papierslib en 4) $8 \%$ hout 'chips', $39 \%$ sloophout en $53 \%$ snoeihout. De aandelen in het brandstofmengsel zijn gebaseerd op massa ('as received'). Deze resultaten komen overeen met operationele ervaring en met de resultaten van de luchtgekoelde sondes.

Naast het effect van het meestoken van biomassa op operationele as-gerelateerde problemen, kunnen er ook effecten zijn op de milieuaspecten van vliegassen. Dit is vooral in Nederland belangrijk omdat hier vliegas op grote schaal wordt toegepast in beton. Eerder werd al gerapporteerd dat het meestoken van biomassa tot een percentage van $15 \%$ (op basis van droge massa) de vliegassamenstelling niet erg beïnvloedt en de milieueigenschappen van meestookassen equivalent zijn aan die van kolenvliegas. Echter is niet alleen de concentratie van elementen van belang, maar ook hun speciatie (bijvoorbeeld de oxidatietoestand en/of molecuulstructuur). Dit is vooral van toepassing op chroom omdat $\mathrm{Cr}(\mathrm{VI})$ uitloogbaar is en $\mathrm{Cr}$ (III) niet zo zeer, en $\mathrm{Cr}(\mathrm{VI})$ carcinogeen en giftiger is dan $\mathrm{Cr}(\mathrm{III})$. Voor het bepalen van de oxidatietoestand van chroom in vliegas is een analysetechniek nodig met een detectiegrens in het ppm-bereik en dient extractie middels oplossing voorkomen te worden omdat dit een significante bron van onzekerheid en fouten vormt. Zo'n techniek is X-ray absorption finestructure (XAFS) spectroscopy. Deze techniek is toegepast op vliegassen van zowel kolen stoken als biomassa meestoken in combinatie met relatieve verrijkingsfactoren. Door de resultaten van de analyses en thermodynamische berekeningen te combineren is een beter begrip verkregen van de processen die de chroom speciatie bepalen. Chroom dat in kolen gebonden is in illiet of als driewaardig oxide wordt opgenomen in de aluminiumsilicaat smelt, zal ongewijzigd blijven tijdens de verbranding. In beide gevallen zal chroom in vliegas voorkomen als niet-uitloogbaar $\mathrm{Cr}(\mathrm{III})$. Organisch gebonden chroom in kolen of biomassa kan verdampen tijdens de verbranding en wanneer voldoende zuurstof aanwezig is voorkomen als $\mathrm{CrO}_{3}(\mathrm{~g})$ in de rookgassen. $\mathrm{Bij}$ afkoeling kan $\mathrm{CrO}_{3}(\mathrm{~g})$ worden gebonden door een oppervlaktereactie aan vliegasdeeltjes met bijvoorbeeld $\mathrm{Ca}, \mathrm{Mg}, \mathrm{K}, \mathrm{Na}$ of $\mathrm{Fe}$ als uitloogbaar $\mathrm{Cr}(\mathrm{VI})$. In het geval dat $\mathrm{CrO}_{3}(\mathrm{~g})$ reageert met barium zal chroom voorkomen in de vliegas als niet-uitloogbaar $\mathrm{Cr}(\mathrm{VI})$. Zonder voldoende zuurstof kan $\mathrm{CrO}_{3}(\mathrm{~g})$ reageren tot een oxide van een lagere oxidatiegraad en in de vliegas voorkomen als $\mathrm{Cr}_{2} \mathrm{O}_{3}(\mathrm{~s})$. 


\subsection{Reducing $\mathrm{CO}_{2}$ emissions from coal-fired power plants}

The average earth's climate system is warming, as can be observed from Figure 1.1. According to climate researchers, the dominant cause of warming since the 1950's is human influences [1]. The largest human influence is the emission of greenhouse gases, which include (amongst others) $\mathrm{CO}_{2}$. The climate researchers predict that a continuing emission of greenhouse gases will have a number of undesired effects, which include (amongst others), rise of global mean sea level. Therefore they conclude that "limiting climate change will require substantial and sustained reductions of greenhouse gas emissions."

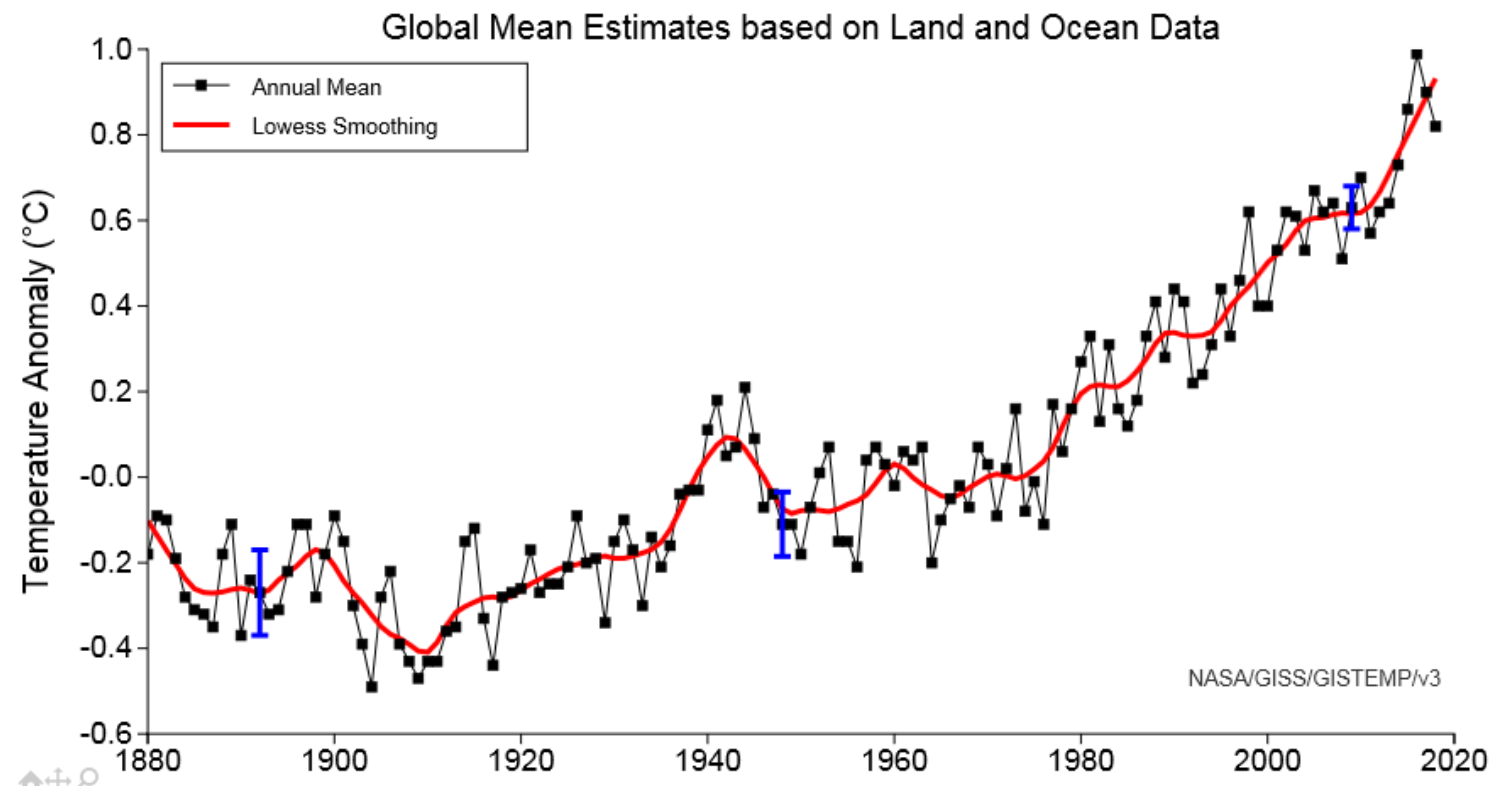

Figure 1.1 Land-ocean temperature index, 1880 to present, with base period 1951-1980. The solid black line is the global annual mean and the solid red line is the five-year LOWESS smooth. The blue uncertainty bars (95\% confidence limit) account only for incomplete spatial sampling. Source: [2].

The highest contributors to releasing $\mathrm{CO}_{2}$ to the atmosphere mentioned in [1] are fossil fuel combustion and cement production. $\mathrm{CO}_{2}$-emissions from coal-fired power stations are highest per kWh of generated electricity of all forms of power generation. For example, the specific $\mathrm{CO}_{2}$ emission of a pulverized coal-fired plant is higher compared to that of a gas-fired combined cycle 
plant [3] due to the higher carbon content in the fuel and the lower plant efficiency ${ }^{1}$. To reduce $\mathrm{CO}_{2}$-emissions from coal-fired plants, the following measures are possible:

- increase of plant efficiency;

- carbon capture and storage (CCS);

- biomass co-firing.

\subsubsection{Increase of plant efficiency}

Plant efficiency is theoretically limited by the cycle efficiency of an ideal cycle process, the Carnot efficiency: $\eta_{\text {Carnot }}=1-\frac{T_{\text {sink }}}{T_{\text {source }}}$. $T_{\text {sink }}$, the condenser temperature, cannot be influenced other than choosing the location of the plant at the coast to use sea water cooling, which is generally the cooling medium with the lowest temperature that is available. $T_{\text {source, }}$ the average temperature at which heat is supplied to the cycle process can be increased by applying reheating or even double reheat [4] and by increasing the maximum steam temperature. The efficiency of coal-fired plants built in Germany in 1950 has been about 32\% (LHV-basis) [5]. Plant efficiency has continuously increased since then as a result of application of higher steam temperatures allowed for by the use of materials with higher creep strength. Coal-fired plants built in Europe around 2015 have an efficiency of about $46 \%$. Austenitic stainless steels are applied in these recently built plants that are exposed to superheat and reheat temperatures of $600{ }^{\circ} \mathrm{C}$ and 620 ${ }^{\circ} \mathrm{C}$, respectively. Further efficiency increase is possible by applying nickel alloys. Research projects have been performed to apply steam temperatures of $700{ }^{\circ} \mathrm{C}$ [4] or even $750{ }^{\circ} \mathrm{C}$ [6] to realise efficiencies of $>50 \%$ (LHV-basis). High cost of required $\mathrm{Ni}$-alloys and lack of full-scale demonstration are main drawbacks for $700{ }^{\circ} \mathrm{C}+$ technology.

\subsubsection{Carbon capture and storage}

There are three main ways to capture $\mathrm{CO}_{2}$ emitted from fossil-fuel fired power plants: postcombustion, pre-combustion and oxyfuel technology. An overview of these three ways is shown in Figure 1.2. Post-combustion $\mathrm{CO}_{2}$-capture is an end-of-pipe solution where carbon dioxide is separated from the flue gases. With pre-combustion technology, coal is gasified wherafter which the yielded $\mathrm{CO}$ is converted to $\mathrm{CO}_{2}$ and separated from the syngas. In oxyfuel plants, nearly pure oxygen is separated from air and is used for combustion resulting in a flue gas with high carbon dioxide concentration from which $\mathrm{CO}_{2}$ can be separated quite easily. Several capture technologies are available of which the most mature are mentioned in the following. For postcombustion they are: chemical and physical absorption, adsorption, cryogenic separation and

\footnotetext{
${ }^{1}$ For example: the modern coal-fired power station MPP3 in The Netherlands (commissioned 2016) has an efficiency of $47 \%$ and a specific $\mathrm{CO}_{2}$ emission of $728 \mathrm{~g} / \mathrm{kWh}$ while a modern gas-fired combined cycle has an efficiency of $58 \%$ and a specific $\mathrm{CO}_{2}$ emission of $358 \mathrm{~g} / \mathrm{kWh}$
} 
membrane separation. Available pre-combustion technologies are physical and chemical absorption and also physical adsorption. The captured $\mathrm{CO}_{2}$-rich gas-stream is dehydrated, compressed and transported to a storage site, which can be for instance subsurface porous layers of exhausted oil and gas reservoirs. The main drawback of CCS is the (high cost of) large power consumption of the involved separation processes, leading to increased use of fossil fuels. Other drawbacks, amongst others, are the high investment costs and a lack of full-scale demonstration.

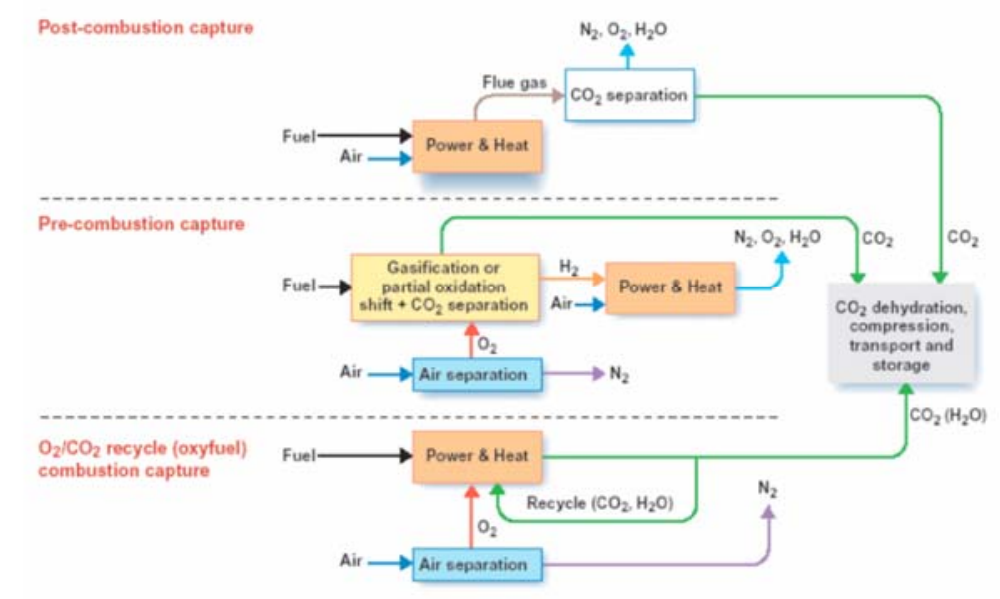

Figure 1.2 The three main $\mathrm{CO}_{2}$ capture solutions for power plants; source: [7].

\subsubsection{Biomass co-firing}

The rationale behind $\mathrm{CO}_{2}$ emission reduction via (co-)firing of biomass is as follows. Coal has been formed from biological material over millions of years. By combusting coal on large scale, the $\mathrm{CO}_{2}$, which was originally taken up from the environment, is released in a relatively very short time causing a significant increase of the $\mathrm{CO}_{2}$ concentration in the atmosphere. On the other hand, the $\mathrm{CO}_{2}$ released by combustion of biomass is taken up from the atmosphere by growing of new plants and trees and because of the short cycle of months or years there is (almost) no net contribution to the $\mathrm{CO}_{2}$ concentration of the atmosphere. It is noted, though, that $\mathrm{CO}_{2}$ emissions from biomass combustion are non-zero due to forestry, biomass transport and fuel preparation.

Three options for biomass co-firing in coal plants exist [8]: direct co-firing whereby pre-processed biomass is fed to the boiler furnace, indirect co-firing whereby biomass gasification gas is fed to the boiler furnace and parallel combustion whereby biomass is combusted in a dedicated boiler and the produced steam feeds into the coal-fired boiler's steam system. An overview of these options is shown in Figure 1.3. 


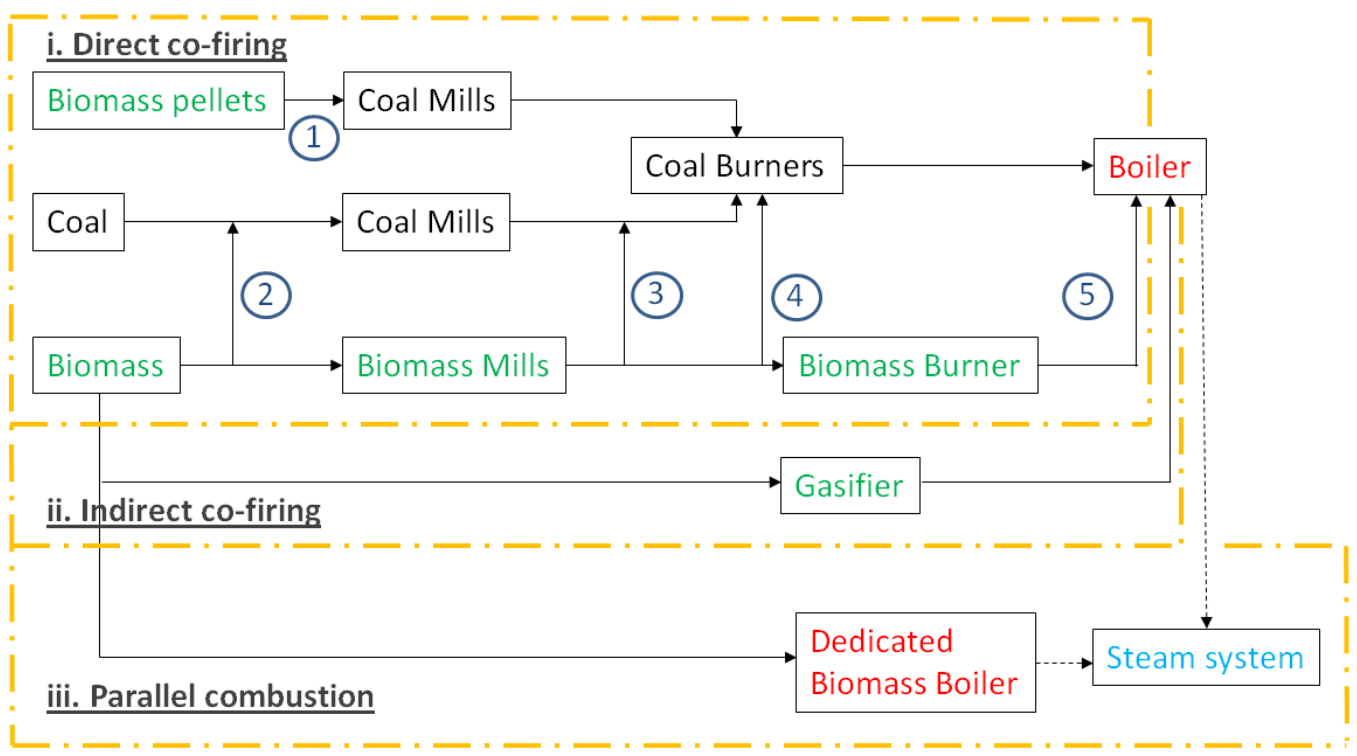

Figure 1.3 Biomass co-firing options at large pulverised coal-fired power plants (adapted from [9]).

Several options (numbered 1 to 5 in Figure 1.3) exist for direct co-firing; a review of these options can be found in [10]. With option 1, sawdust pellets are fed to the existing coal mills and the dust is transported to an existing coal burner. Maximum use of the existing infrastructure is made, although modification of mills and burners may be required. This approach has been successfully demonstrated in a small number of plants. An even simpler approach is option 2 whereby biomass is pre-mixed with coal and is processed along with the coal in the existing systems. Little capital investments are needed and it can be implemented fairly quickly. About $10-12 \%$ (on basis of thermal heat input) of coal can be replaced in this approach. This has been a very popular approach, especially for power plants implementing biomass co-firing for the first time. With options 3, 4 and 5, dedicated biomass mills are used since many biomass types cannot be sufficiently reduced in size in the coal mills. The milled biomass is either injected in the pulverized fuel lines (option 3), or fed to coal burners (option 4) or fed to dedicated biomass burners (option 5). Capital investments with these options are much higher than for option 2, but much higher cofiring ratios can be achieved and these options seem to be the most favoured for new build pulverised coal power plants.

With indirect biomass co-firing, biomass is gasified at a temperature of $850{ }^{\circ} \mathrm{C}$ in a circulating fluidized bed boiler under sub-stoichiometric combustion conditions. The benefit of a gasifier is that a large range of fuels can be accommodated while fuel pre-treatment requirements are low compared to those for direct co-firing. A large part of the alkalis will remain with the ashes that 
are removed from the fuel gas in the biomass gasification process. Hence, the alkali load of the coal-fired boiler is much lower compared to the direct co-firing route, which reduces the risk of fouling and high temperature corrosion. In spite of these alleged advantages, indirect co-firing has remained on a demonstration level which is likely due to the fact that investment costs are relatively high compared to direct co-firing.

The advantage of parallel co-firing is that there are no possible negative fuel impacts on the coalfired boiler as described under direct co-firing. However, due to high investment cost, few examples of full scale demonstration exist.

Direct biomass co-firing can be retrofitted to coal-fired power plants as has been shown successfully in several plants in The Netherlands, Belgium, the UK and Denmark. Furthermore, power plants in Denmark, Belgium and the UK have been converted from coal only to biomass only. Biomass co-firing is a technology that is commercially available and reasonably well established, particularly in Northern Europe. The projects can be retrofitted to existing plant and projects can be implemented fairly quickly, and the capital expenditure is modest, because maximum use is made of the existing equipment and infrastructure. For these reasons, it is very likely that biomass co-firing will continue to play a significant role in the achievement of the $\mathrm{CO}_{2}$ reduction goals in the European Union and elsewhere. However, due to its physical and chemical properties, there are technical issues with replacing coal by biomass. Main areas of interest are storage, transport and preparation, conversion, slagging, fouling, corrosion, flue gas cleaning, waste water treatment, emissions and quality of by-products.

\section{$1.2 \quad$ Motivation}

Research in Danish coal-fired boilers co-firing straw showed that slagging increased with increasing straw co-firing rate [19]. Ash deposition problems with co-firing biomass have also occurred in coal-fired boilers in The Netherlands. However, it is unknown whether these problems can (partly) be attributed to co-firing biomass. It is foreseen that in The Netherlands biomass co-firing percentages will be increased and also that coal-fired boilers will be completely converted to biomass to comply with government $\mathrm{CO}_{2}$-emission goals. Co-firing percentages of over $20 \%$ biomass with coal have been demonstrated in The Netherlands only on experimental basis. Hence, the lack of understanding the influence of an increase in biomass to coal ratio on ash deposition (slagging and fouling) introduces a risk on further implementation of biomass cofiring.

It is anticipated that due to the difference in ash composition between coal and biomass, the stickiness of the slag and the amount of slag formed may change. The most used co-firing fuel in The Netherlands is wood, while a few plants (also) co-fire MBM (Meat and Bone Meal). Little operating experience on slagging with co-firing of wood has been published. Results from pilot- 
scale test facilities and full scale tests vary: no change, increasing or decreasing problems [11, 12,13]. An attempt to use standard fusibility correlations to evaluate the influence of co-firing wood on boiler slagging gave non-equivocal results [11]. So far, no results have been published on practical experience with co-firing MBM with coal in a pulverized fuel fired plant. Limited results have been published on modelling ash deposition for co-firing biomass with coal. These modelling results relate to other fuels [14]. The extent to which chemical elements are available for reaction, "element availabilities" (e.g. in [14, 15]), are partly based on fuel characterizations that not have been compared with actual element availabilities, and are partly based on the concept of a reactive layer. The latter was derived from earlier experimental work on alkali-silica interactions derived in a lab-scale environment and did not allow for the interactions of alkalis with aluminosilicate glass that are likely to play an important role in co-firing biomass with coal in practice. A modelling approach with element availability based on practical conditions is required to successfully support plant operators in selecting the fuel diet.

It is the experience of operators of coal-fired power plants in the Netherlands, that with low cofiring ratio's (i.e. up to $20 \%$ wood on basis of fuel mass (a.r.)), deposition of molten salts and high-temperature corrosion does not increase compared to firing only coal. However, fouling and corrosion can be problematic with firing only biomass in dedicated biomass boilers, see e.g. [16]. In general, the alkali concentration in biomass fuel ash is higher than in coal ash. Also, alkalis in biomass will generally volatize to a larger extent. After devolatilization, alkalis can interact with aluminosilicates, i.e. dissolve in the glass phase or be chemisorbed by kaolinite. In fact, coal ash and kaolinite are used as additive to reduce fouling and corrosion problems ([17], [18]). Due to the differences in fuel composition and firing temperature (the maximum firing temperature in coal-fired boilers is normally (much) higher than in dedicated biomass boilers), the interaction of $\mathrm{K}$ and $\mathrm{Na}$ with ash forming matter may be fundamentally different in coal vs. biomass boilers. For example, due to the formation of molten aluminosilicates above approximately $900{ }^{\circ} \mathrm{C}$ different compositions and amounts of deposits can be formed. Andersen [19] concluded from a study on co-firing straw with coal in a dedicated coal-fired boiler that $\mathrm{K}$ in deposits was mainly associated with aluminosilicates whereas Miles et al. [16] observed $\mathrm{K}$ as $\mathrm{K}_{2} \mathrm{SO}_{4}$ in deposits with firing straw. Some results on the effect of co-firing biomass on the interaction of alkalis with aluminosilicates have been published. For biomass fuels co-fired in the Netherlands, like wood and MBM-mix, Sarabèr [20] concluded on basis of full-scale results that alkalis are associated with aluminosilicates and that the concentration of elements $\mathrm{K}, \mathrm{Ca}$ and $\mathrm{Mg}$ will increase with co-firing. For co-firing of straw, Zeng et al. [21] found an increased amount of water soluble $\mathrm{K}$ in fly ash (i.e. not in slag) with increased ratio of $\mathrm{K}: \mathrm{Si}$ in the fuel with co-combustion of coal and straw in a lab-scale entrained flow reactor. However, a more general description of alkali ash interaction with biomass co-firing has not been published.

Volatile alkalis that do not interact with aluminosilicates will condense upon cooling of the flue gases. This can be heterogeneous or homogeneous condensation. In the latter case, aerosols form that can build up on tubes to form a molten alkali salt deposit of various compositions. 
Problematic alkali deposits occur generally at a flue gas temperature of around $700{ }^{\circ} \mathrm{C}$, as for example was observed for a boiler converted from coal to straw, see [22]. Already decades ago, it was recognized that the ratio of $\mathrm{S}$ and $\mathrm{Cl}$ in the fuel influences the composition of deposits in pulverized fuel boilers. Crumley et al. (1955) conducted a series of experiments where they combusted a mixture of kerosene, calciumaphtalene $\left(\mathrm{C}_{10} \mathrm{H}_{6} \mathrm{CaO}_{6} \mathrm{~S}_{2}\right)$, carbondisulphide $\left(\mathrm{CS}_{2}\right)$ and chlorobenzene $\left(\mathrm{C}_{6} \mathrm{H}_{5} \mathrm{Cl}\right)$ [23]. With a ratio of $\mathrm{S} / \mathrm{Cl}=0.5$ in the fuel, the ratio of calcium sulphate and calcium chloride in the combustion ashes was about $1: 1$. For $\mathrm{S} / \mathrm{Cl}>3$, the amount of formed calcium chloride drastically dropped. It was reasoned that calcium chloride will melt (the melting point of $\mathrm{CaCl}_{2}$ lies at $782{ }^{\circ} \mathrm{C}$ while $\mathrm{CaSO}_{4}$ melts at $1460{ }^{\circ} \mathrm{C}$ ) and will bind particles in the deposit. Later on, calcium chloride would sulfatize due to gaseous sulfur in the flue gases. Chlorides in deposits generally increase corrosion rates of boiler tubes. Salmenoja [24] conducted a series of lab scale and large scale experiments and on basis of the results it was concluded that corrosion problems were often experienced with $\mathrm{S} / \mathrm{Cl}<2$ whereas chlorideinduced corrosion problems were rarely experienced if $\mathrm{S} / \mathrm{Cl}>4$. These conclusions are rules of thumb and are derived for fluidized bed boilers, firing wood-based fuel blends. Full scale results regarding fouling in coal-fired pf boilers with fuel blends similar to those as fired in The Netherlands, have not been published in the open literature. Whether the aforementioned rules of thumb apply to these blends or if other (maybe similar) rules should be derived has not been investigated. Nonetheless, this rule of thumb is generally practiced by operators of coal-fired power plants. Also, thermodynamic modelling results simulating fouling involving the ratios of $S$, $\mathrm{Cl}, \mathrm{K}$ and $\mathrm{Na}$, in particular for pf boilers, have not been published. From the rules of thumb presented in [24], it can easily be understood that increasing the $S$ to $\mathrm{Cl}$ ratio by means of a sulphur-based additive (for instance, ammonium sulphate $\left(\left(\mathrm{NH}_{4}\right)_{2} \mathrm{SO}_{4}\right)$ ) could overcome fouling problems and such additives are commercially available, see e.g. [25]. It has not been investigated if such additives are applicable to firing fuel blends as fired in The Netherlands or if limitations to the applicability exist.

Fluidized bed boilers are designed to accept a wide range of fuels, i.e. the operating window for particle size, moisture and ash content, calorific value, et cetera, is quite broad - contrary to pulverized fuel boilers. However, a number of residual streams exist that may fit this operating window, but are problematic in terms of fouling. In spite of their economic attractiveness, these problems have restricted the wide utilization of such fuels [26]. This aforementioned situation also applies to the BFB in Cuijk, The Netherlands. After a 10-year period of firing wood chips with little fouling problems, the plant was forced to divert to other fuels, allowing for economically viable operation. Different fuels blends led to varying degrees of problematic fouling. Understanding of the fouling behaviour of such fuels, on basis of which models can be developed to predict that behaviour, is of great interest. Results of full scale trials are required to gain a profound understanding of the fouling behaviour. Some full-scale results have been published; see e.g. [26], [16] and [27]. However, these fuel blends are different from those fired in the BFB in Cuijk. 
Fouling prediction modelling for biomass-fired fluidized bed boilers, based on thermodynamic equilibrium, has been presented by e.g. Zevenhoven-Onderwater, see [28]. Based on experience with fouling in black liquor recovery boilers, the fouling indicator in this model, traditionally, relates to the melt percentage of total ash. The reasoning is that ash particles have to contain a certain amount of liquid melt to deposit. This, however, assumes an even distribution of the melt fraction among the different particles which is not always necessarily true, e.g. if homogeneous condensation is favoured, and because particle size is distributed. It could also be reasoned that if the deposit surface is sticky, impacting particles can stick to that surface. This would not be related to the percentage of melt in the total ash, but to the extent to which a melt is present at the deposit temperature (i.e. temperature range between metal surface and local flue gas temperature). A comparison of these approaches has not been reported in literature.

Aside from the effect of co-firing biomass on operational ash related problems, co-firing biomass may also have an influence on the environmental properties of fly ash. In The Netherlands, this is of particular importance, since fly ash is re-used for concrete on a large scale [20]. On basis of large scale tests, it was found by Meij et al. [29] that with co-firing up to $15 \%$ (mass input, dry) "the changes in the ash composition as a consequence of co-combustion are not very great and lie within the normal range for ashes resulting from the firing of coal of various origin" and "cocombustion coal ash, as produced in The Netherlands, is equivalent to coal ash from full coalfiring with respect to technical and environmental properties." However, not only the concentration of (trace) elements is important, but also their speciation (e.g. according to oxidation state and/or molecular structure). This is particularly true for chromium, since $\mathrm{Cr}(\mathrm{VI})$ is leachable whereas $\mathrm{Cr}(\mathrm{III})$ is not so, and $\mathrm{Cr}(\mathrm{VI})$ is carcinogenic and more toxic than $\mathrm{Cr}(\mathrm{III})$, causing nose bleeding, ulcer, visceral damage, inflamed skin, festering, lung cancer and even death [30], [31]. Thermodynamic calculations have been performed to evaluate the effect of cofiring wood on $\mathrm{Cr}$ speciation [32], but results have not been compared with experimental data. Analytical methods for speciation of chromium in aqueous solutions exist, but for solid substances, a complete extraction of chromium prior to application of these methods would be required; this would be a significant source of uncertainty and error in the determination of chromium oxidation states [33]. Therefore, Huggins et al. [33] state that: "to avoid such problems, it would be better to use a direct, non-destructive technique to determine the oxidation state of chromium in the solid. One technique that appears to be capable of such determinations with a detection limit for chromium oxidation states in solids in the ppm range is X-ray absorption finestructure (XAFS) spectroscopy." XAFS data for fly ash resulting from biomass co-firing have not been published in the open literature.

In summary, not much scientific information is available on the ash related problems for biomass co-firing. Most insights are derived from lab scale tests. Where results apply to full-scale, they are mostly derived for coal-firing only or for fluidized bed boilers firing only biomass. The few results related to biomass co-firing are inconsistent or are derived for biomass fuels of very different composition than that are used in the Netherlands. This thesis therefore focusses on co-firing of 
wood and MBM in full-scale pulverized coal-fired power plants with a view to increase co-firing percentages well in excess of $20 \%$ (on basis of mass input) as a means to decrease $\mathrm{CO}_{2}$ emissions.

\subsection{Objectives}

The main goal of this thesis is to investigate how biomass co-firing will influence ash deposition characteristics compared to pure coal firing. This main goal is subdivided in seven scientific research goals:

1. Since the influence of biomass co-firing on slagging is not well understood and since there are limited practical or theoretical results available from which this understanding could be derived, the first research objective is to explain superheater slagging in coal-fired boilers co-firing biomass. Full scale deposition tests using air-cooled probes and microscopic analyses of the deposits are performed to get insight in the formation of the depositing phases and to explain mechanisms of deposit build-up. Thermodynamic modelling is applied to simulate the occurrence of molten phases and to explain the measured data.

2. A second objective hereby is to develop a prediction model for slagging propensity for co-firing biomass with coal and to verify the suitability of thermodynamic calculations as a basis for prediction of slagging.

3. Fouling by deposition of alkali salts is a problem largely experienced in dedicated biomass boilers. With increased biomass/coal ratios, this may become an issue with biomass co-firing in pulverized fuel boilers. The third objective is to gain more insight in the high temperature process (above approximately $900{ }^{\circ} \mathrm{C}$ ) of interaction between $\mathrm{K}, \mathrm{Na}$ and fuel ash when (co-) firing biomass in dedicated coal-fired boilers, i.e. how this interaction is influenced by the chemical composition of the glass phase. This is done by a) investigating fly ashes generated with full-scale biomass co-firing experiments with Scanning Electron Microscopy (SEM) and b) simulating the behaviour of alkalis during combustion with thermodynamic equilibrium calculations.

4. The fourth objective is to investigate the effect of the elemental ratio of $\mathrm{K}, \mathrm{Na}, \mathrm{S}$ and $\mathrm{Cl}$ on the low temperature process (below approximately $900{ }^{\circ} \mathrm{C}$ ) of formation of molten alkali salt, therewith presenting a theoretical basis for fouling in a pf boiler co-firing biomass with coal. This is again done by thermodynamic calculations, simulating the chemistry during combustion of coal and biomass (co-) firing, as well as addition of ammonium sulphate $\left(\left(\mathrm{NH}_{4}\right)_{2} \mathrm{SO}_{4}\right)$ with firing only biomass.

5. The fifth objective is to explain and predict ash deposition at superheaters in the biomass-fired BFB boiler in Cuijk. Full scale deposition tests using air-cooled probes and microscopic analyses of the deposits are performed to get insight in the formation of the depositing phases and to explain mechanisms of deposit build-up. 
6. The sixth objective is to develop an alternative modelling approach to predict the fouling propensity for firing biomass fuels in a fluidized bed boiler. The approach includes a fouling indicator related to the extent to which a melt is present at the deposit temperature rather than to the percentage of melt in the total ash. Next, both results will be compared with the results obtained from full-scale testing.

7. Lastly, the quality of fly ashes that are used in cement production could be compromised, specifically in regards to $\mathrm{Cr}(\mathrm{VI})$. The seventh objective of this thesis is to gain a better understanding of the formation process of chromium speciation as these processes can be affected by (co-)firing biomass. This understanding is obtained by combining analysis results (XAFS, leaching), RE-factors and thermodynamic calculations. Not only ash samples from pulverized fuel combustion, but also samples from gasification and biomass fluidized bed combustion are evaluated to take into account extremes of oxygen content in the flue gas, and pure biomass as fuel.

\section{$1.4 \quad$ Outline of the thesis}

The general theory of ash deposition is discussed in Chapter 2. A review of methods to predict slagging and fouling with co-combustion are discussed in Chapter 3. A new model for predicting slagging with coal and co-firing wood and MBM-mix with coal, along with full-scale measurements using air cooled probes is presented in Chapter 4. The influence of co-firing biomass with coal and full conversion from coal to biomass on fouling is discussed in Chapter 5 . Also, ways to control fouling by addition of coal fly ash or ammonium sulphate are simulated and results are presented. Full scale trials in a dedicated biomass fluidized bed boiler have been performed and are presented along with a prediction model for fouling in Chapter 6 . The effect of co-firing biomass on chromium speciation in fly ash, i.e. the formation of $\mathrm{Cr}(\mathrm{VI})$ is investigated in Chapter 7. Conclusions are given in Chapter 8 and recommendations in Chapter 9.

\section{References}

[1] IPCC, 2013: Summary for Policymakers. In: Climate Change 2013: The Physical Science Basis. Contribution of Working Group I to the Fifth Assessment Report of the Intergovernmental Panel on Climate Change [Stocker TF, Qin D, Plattner G-K, Tignor M, Allen SK, Boschung J, Nauels A, Xia Y, Bex V, Midgley PM (Eds.). Cambridge University Press, Cambridge, United Kingdom and New York, NY, USA.

[2] https://data.giss.nasa.gov/gistemp/graphs/ visited March 2019; the graph is an update from Fig. 9a in Hansen J, Ruedy R, Sato M, Lo K. Global surface temperature change. Rev Geophys, 2010, 48, RG4004. 
[3] Rooijers F, Croezen H, Blommerde J. $\mathrm{CO}_{2}$-reductie bij een moderne kolencentrale. Delft, CE Delft, 2016.

[4] Blum R, Bugge J, Kjaer S. USC $700{ }^{\circ} \mathrm{C}$ Power Technology - A European success story. VGB PowerTech, 2009, 4, 26-32.

[5] Kruhl J. COORETEC Working Group \#2 Steam Power Plants \& Post Combustion Capture. 23 April 2008.

[6] Stam AF. NextGenPower - Demonstration and component fabrication of nickel alloys and protective coatings for steam temperatures of $750^{\circ} \mathrm{C}$. Presented at the Seventh International Conference on Advances in Materials Technology for Fossil Power Plants, October 22 - 25, 2013, Waikoloa, Hawaii, USA.

[7] VGB PowerTech e.V., $\mathrm{CO}_{2}$ Capture and Storage - A VGB Report on the State of the Art, 2004

[8] Van Loo S, Koppejan J (Eds.) Handbook of Biomass Combustion and Co-Firing. Twente University Press, Enschede, 2002.

[9] Livingston WR, Morris K. Experience with co-firing biomass in PC boilers to reduce $\mathrm{CO}_{2}$ emissions. Powergen International, Las Vegas, Dec 2009.

[10] Livingston WR. The status of large scale biomass firing. The milling and combustion of biomass materials in large pulverised coal boilers. IEA Bioenergy: Task 32: Biomass Combustion and Cofiring, 2016.

[11] Pronobis M. Evaluation of the influence of biomass co-combustion on boiler furnace slagging by means of fusibility correlations. Biom Bioener, 2005, 28, 375-83.

[12] Heinzl T, Siegle V, Spliethoff H, Hein KRG. Investigation of slagging in pulverized fuel cocombustion of biomass and coal at a pilot-scale test facility. Fuel Proc Tech, 1998, 54, 109-25.

[13] Smajevic I, Kazagic A, Music M, Becic K, Hasanbegovic I, Sokolovic S, Delihasanovic N, Skopljak A, Hodzic N. Co-firing Bosnian coals with woody biomass: experimental studies on a laboratory-scale furnace and 110 MWe power unit. Therm Sci, 2012, 16, 789-804.

[14] Plaza, PP. The development of a slagging and fouling predictive methodology for large scale pulverised boilers fired with coal/biomass blends. PhD Thesis, Cardiff University, 2013. 
[15] Doshi V, Vuthaluru HB, Korbee R, Kiel JHA. Development of a modeling approach to predict ash formation during co-firing of coal and biomass. Fuel Proc Tech, 2009; 90, 1148-56.

[16] Miles Sr TR, Miles Jr TR, Baxter LL, Bryers RW, Jenkins BM, Oden LL. Boiler deposits from firing biomass fuel. Biomass Bioenergy, 1996, 10, 125-28.

[17] Damoe AJ, Wu H, Frandsen FJ, Glarborg P, Sander B. Impact of coal fly ash addition on combustion aerosols (PM2.5) from full-scale suspension-firing of pulverized wood. Energy Fuels, 2014, 28, 3217-23.

[18] Steenari B-M, Lindqvist O. High temperature reactions of straw ash and the anti-sintering additives kaolin and dolominte. Biomass Bioenergy, 1998, 14, 67-76.

[19] Andersen KH. Deposit Formation during Coal-Straw Co-Combustion in a Utility PF-Boiler. PhD Thesis, Technical University of Denmark, 1998.

[20] Sarabèr A. Fly ash from coal and biomass for use in concrete. Origin, properties and performance. PhD thesis, TU Delft, 2017.

[21] Zheng Y, Jensen PA, Jensen AD. Appendix D: Potassium capture by kaolin and fly ash powder in an entrained flow reactor. In: Ash transformation in suspension fired boilers co-firing coal and straw. Final report, PSO-Eltra 4766, Technical University of Denmark, Department of Chemical Engineering. CHEC, No. R0803, 2009.

[22] Tobiasen L, Skytte R, Storm Pedersen I, Thaaning Pedersen S, Lindberg MA. Deposit characteristic after injection of additives to a Danish straw-fired suspension boiler. Fuel Proc Technol, 2007, 88, 1108-17.

[23] Crumley PH, Fletcher AW, Wilson DS. The formation of bonded deposits in pulverized-fuelfired boilers. J I Fuel, 1955, 28, 117-20.

[24] Salmenoja K. Field and laboratory studies on chlorine-induced superheater corrosion in boilers fired with biofuels, PhD Thesis, 2000, Report 00-1, Faculty of chemical engineering, Åbo Akademi University, Turku, Finland.

[25] Henderson P, Sakálos P, Pettersson R, Andersson C, Högberg J. Reducing superheater corrosion in wood-fired boilers. Materials Corrosion, 2006, 57, 128-34.

[26] Peltola K, Hiltunen M, Blomqvist J-P, Skrifvars B-J, Kurkela J, Latva-Somppri J, et al. Fouling of the cooling surfaces in biofuels-fired fluidized bed boilers. In: Reuther RB, editor. Proceedings 
of the 15th International Conference on Fluidized Bed Combustion; May 16-19, 1999; Savannah, Georgia, USA. Savannah: ASME; 1999.

[27] Skrifvars B-J, Hupa M. (Åbo Akademi University, Åbo/Turku, Finland). Ash Chemistry and behavior in advanced co-combustion. In: Spliethoff $\mathrm{H}$, Hein KRG, editors. Final report of the EU/JOULE 3 project Operational problems, trace element emissions and by-product management for industrial biomass co-combustion. Brussels: EU/JOULE; 1999. Contract No.: JOF3-CT95-0010.

[28] Zevenhoven-Onderwater M. Ash-Forming Matter in Biomass Fuels. PhD Thesis, Turku: Åbo Akademi, 2001.

[29] Meij R, Te Winkel H, Sarabèr A. Environmental effects of co-combustion of biomass in coalfired power stations in The Netherlands. Presented at Power-Gen Europe, Barcelona, Spain, 25 -27 May 2004.

[30] Toward mechanisms of metal carcinogenesis: biological effects of metals. Fishbein $L$ and Furst A. Eds.; Plenum Press: New York, 1987, pp 295-327.

[31] Basic environmental toxicology. Cockerham LG and Shane BS; CRC Press: Florida, 1994, pp 121-128.

[32] Stam AF, Meij R, Te Winkel BH, Cieplik M. Predictions of the speciation of elements in coal ash with thermodynamic equilibrium calculations for advanced techniques in pf-coal-fired power plants co-firing biomass, 32nd International Conference on Coal Utilization \& Fuel systems, Clearwater, USA, Jun 15, 2007.

[33] Huggins FE, Najih M, Huffman GP. Direct speciation of chromium in coal combustion byproducts by X-ray absorption fine-structure spectroscopy. Fuel, 1999, 78, 233 - 42. 


\section{THEORETICAL FRAMEWORK}

\subsection{Slagging and fouling}

Slagging and fouling involves the deposition on surfaces within the boiler; their definitions are adapted from [1]. Slagging refers to deposition of fly ash on heat-transfer surface and refractory in the furnace volume primarily subjected to radiant heat transfer. Fouling is defined as deposition in the heat-recovery section of the steam generator subject to convective heat exchange by fly ash quenched to a temperature below its predicted melting point, condensation by volatiles or sulphidation by $\mathrm{SO}_{3}$. In each zone specific slagging and/or fouling phenomena occur related to the local circumstances such as temperature, gas and ash composition, flow phenomena et cetera.

\subsection{Mineral matter in coal and secondary fuel}

The inorganic constituents of coal and biomass are referred to as mineral matter. According to Couch (1994) mineral matter is everything present in the fuel except for organically-derived or organically-bound $\mathrm{C}, \mathrm{H}, \mathrm{N}, \mathrm{O}$ and $\mathrm{S}$ together with the elements directly bound to the organic matter [2].

\subsubsection{Mineral matter in coal}

Coal is a sedimentary rock which is a complex mixture of organic and inorganic matter. Regarding the mineral matter, differentiation is made between included and excluded minerals. Included minerals are closely associated with pulverized coal and are not separated prior to combustion; excluded minerals are loosely associated and enter the furnace separate from organic matter as separated particles [3]. A graphic representation of included and excluded minerals is given in Figure 2.1.

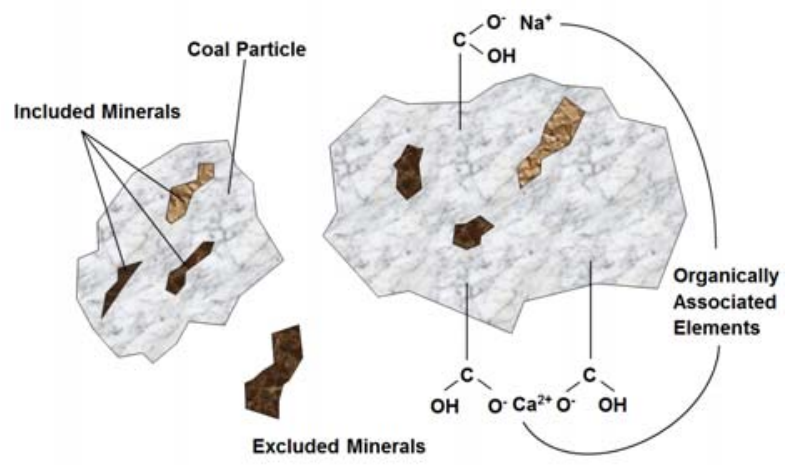

Figure 2.1 Coal with its associated inorganic components; derived from [4]. 
According to Ward (2002) [5], mineral matter can occur as discrete crystalline mineral phases (which are most abundant), amorphous none-crystalline phases, organically associated inorganic elements and salts dissolved in water in the pores (or surface) of the coal. Crystalline minerals form the majority of the mineral matter whereas glassy, amorphous phases occur occasionally. Mineral grains are dispersed unevenly within the coal particles and may be partially separated during combustion. 125 minerals are reported to occur in coal [6] of which over a hundred are accessory or trace minerals. Common mineral phases in coal are given in Table 2.1.

Table 2.1 Common mineral phases in coal, modified from [7], [8].

\begin{tabular}{|c|c|c|c|c|c|}
\hline occurrence & class & type & chemical formula & $\begin{array}{c}\text { melting } \\
\text { point }\left({ }^{\circ} \mathrm{C}\right)\end{array}$ & $\begin{array}{c}\text { decomposition } \\
\text { temperature }\left({ }^{\circ} \mathrm{C}\right)\end{array}$ \\
\hline \multirow{5}{*}{ Major } & \multirow{5}{*}{$\begin{array}{l}\text { silicates clay } \\
\text { minerals }\end{array}$} & kaolinite & $\mathrm{Al}_{2} \mathrm{Si}_{2} \mathrm{O}_{5}(\mathrm{OH})_{4}$ & & \\
\hline & & illite & 1) & & \\
\hline & & mixed layer & 2) & & \\
\hline & & chlorite & $(\mathrm{Mg}, \mathrm{Fe}, \mathrm{Al})_{6}(\mathrm{Si}, \mathrm{Al})_{4} \mathrm{O}_{10}(\mathrm{OH})_{8}$ & & \\
\hline & & quartz & $\mathrm{SiO}_{2}$ & 1710 & \\
\hline \multirow{16}{*}{ Minor } & \multirow{4}{*}{ carbonates } & calcite & $\mathrm{CaCO}_{3}$ & 1339 & 898.6 \\
\hline & & dolomite & $(\mathrm{Ca}, \mathrm{Mg}) \mathrm{CO}_{3}$ & & $730-760$ \\
\hline & & ankerite & $\mathrm{Ca}(\mathrm{Fe}, \mathrm{Mg}) \mathrm{CO}_{3}$ & & \\
\hline & & siderite & $\mathrm{FeCO}_{3}$ & & 527 \\
\hline & \multirow{2}{*}{ disulphides } & pyrite & $\mathrm{FeS}_{2}$ (cubic) & 1171 & \\
\hline & & marcasite & $\mathrm{FeS}_{2}$ (orthorhombic) & & transition 450 \\
\hline & \multirow{8}{*}{ sulphates } & coquimbite & $\mathrm{Fe}_{2}\left(\mathrm{SO}_{4}\right)_{3} \cdot 9 \mathrm{H}_{2} \mathrm{O}$ & & $-7 \mathrm{H}_{2} \mathrm{O}: 175$ \\
\hline & & szomolnokite & $\mathrm{FeSO}_{4} \cdot \mathrm{H}_{2} \mathrm{O}$ & & \\
\hline & & gypsum & $\mathrm{CaSO}_{4} \cdot 2 \mathrm{H}_{2} \mathrm{O}$ & & $-11 / 2 \mathrm{H}_{2} \mathrm{O}: 128$ \\
\hline & & & & & $-2 \mathrm{H}_{2} \mathrm{O}: 163$ \\
\hline & & bassanite & $\mathrm{CaSO}_{4} \cdot 1 / 2 \mathrm{H}_{2} \mathrm{O}$ & & $-1 / 2 \mathrm{H}_{2} \mathrm{O}: 163$ \\
\hline & & anhydrite & $\mathrm{CaSO}_{4}$ & monoclinic & \\
\hline & & & & 1450 & \\
\hline & & jarosite & $\mathrm{KFe}_{3}\left(\mathrm{SO}_{4}\right)_{2}(\mathrm{OH})_{6}$ & & \\
\hline & \multirow{2}{*}{ feldspars } & plagioclase & $(\mathrm{Na}, \mathrm{Ca}) \mathrm{Al}(\mathrm{Al}, \mathrm{Si}) \mathrm{Si}_{2} \mathrm{O}_{8}$ & & \\
\hline & & orthoclase & $\mathrm{KAISi}_{3} \mathrm{O}_{8}$ & & \\
\hline
\end{tabular}

${ }_{1}^{1}$ ) illite has a composition similar to muscovite, chemical formula $\mathrm{KAl}_{2}\left(\mathrm{Si}_{3} \mathrm{Al}\right) \mathrm{O}_{10}(\mathrm{OH})_{2}$, except for less $\mathrm{K}^{+}$and $\mathrm{more}$ $\mathrm{SiO}_{2}$ and $\mathrm{H}_{2} \mathrm{O}$

${ }^{2}$ ) mixed layered clays are usually randomly interstratified mixture of illitic lattices with montmorillonitic and/or chloritic lattices

Mineral concentrations in coal vary per geographic region and also locally within the region. By far the most abundant non-combustible species in coal are those of aluminosilicate clay minerals. Together with quartz, they usually account for between 60 and 90 percent of the total mineral matter in coal [9]. From the clay minerals in Table 2.1, kaolinite, illite and mixed layer illitemontmorillonite are the most common. It is stressed by Renton (1986) [7] that illite is not a mineral but a general term. Carbonates occur as a compound with $\mathrm{Ca}, \mathrm{Mg}, \mathrm{Fe}$ or a combination. 
Feldspars are rarely found in concentrations in coal of more than a few percent [7]. When present in coal, feldspar is mainly found as orthoclase $\left(\mathrm{KAISi}_{3} \mathrm{O}_{8}\right)$. The main occurrence of sulphur is mineral $\mathrm{FeS}_{2}$ or organically bound sulphur. Usually the pyritic sulphur content is similar in amount to the organic sulphur content [10]. Minerals pyrite and marcasite (both $\mathrm{FeS}_{2}$ ) are the principal pyritic minerals found in coal of which pyrite is dominant [11]. Freshly mined coals usually do not contain any significant quantity of sulphates, iron sulphates will form rapidly by sulphide oxidation in air [12]. Chlorine may occur (in decreasing order of significance) as organic compounds, as impurity components in the crystalline and amorphous inorganic constituents, in the fluid constituents and as discrete minerals [13]. Non-crystalline phases can occur as volcanic glass consisting of aluminosilicate (although glass is highly unstable in geologic terms and transforms mainly into clay minerals [14]). The amount of organically associated elements is dependent on the coal rank. Lower rank coals have elevated levels of oxygen $(20-25 \%)$ of which part is in the form of carboxylic acid groups acting as bonding site for cations. These cations can comprise $\mathrm{Na}$, $\mathrm{K}, \mathrm{Ca}, \mathrm{Mg}, \mathrm{Al}$ and $\mathrm{Fe},[1]$, [2], [15], [16]. In lowest rank coals, organically associated inorganic elements can comprise up to $60 \%$ of the total inorganic content, while in higher-ranked coals the inorganic content consists mainly of minerals [2]. Dissolved salts are prominent in lower rank coals. In higher rank coals, dissolved salts are present - if at all - in only relatively low proportions [5].

\subsubsection{Mineral matter in biomass}

In [17], it was concluded that, in contrast with geologically older fuels, younger fuels contain less in- or excluded minerals and up to half of the amount of ash forming elements is present as water or ammonium acetate soluble (hence salts or organically bound).

\subsubsection{Woody biomass}

Wood fuel is mainly available as freshly harvested crop as chips or as dust formed into pellets. Smaller available streams originate from the wood processing industry or is demolition wood. The ash content in wood is generally $1-3 \%$, [1]. Main ash forming elements from wood bark as analysed by Zevenhoven-Onderwater (2001) [17] are Si, Ca and K. Sulphur levels in wood are not measurable [1]. However, analyses from the KEMA biomass database show that sulphur concentration in wood is $0.05-0.25 \%$. Although potassium is found in minor concentrations, its level of concentration is $4-5$ times higher than found in coal [1]. Minerals (including clays) in wood chips (spruce) comprise about $>9 \%$ of the ash (mainly Si and Ca minerals) whereas in wood bark (spruce) this is about $>25 \%$ (mainly Ca and Si) [18]. According to Doshi [18] and Zevenhoven-Onderwater (2001) [17] calcium minerals in wood bark are probably calcite or calcium oxalate. Silicon can be present as sand or soil contamination [1]. Silicon is deposited as a hydrated oxide $\left(\mathrm{SiO}_{2} \cdot \mathrm{nH}_{2} \mathrm{O}\right)$ usually in amorphous, but occasionally in crystalline forms [19]. Organically bound elements in wood chips comprise about $>32 \%$ of the ash (mainly $\mathrm{Ca}$, $\mathrm{K}$ and 
also $\mathrm{Mg}$ - to a smaller extent $\mathrm{Al}$ and $\mathrm{Na}$ ) whereas in wood bark this is about $>26 \%$ (mainly $\mathrm{Ca}$, $\mathrm{Al}$ and $\mathrm{K}$ and also $\mathrm{Mg}$ - to a smaller extent phosphate and $\mathrm{Na}$ ) [18]. Salts and free ions in wood chips and bark (spruce) comprise about $>44 \%$ of the ash, mainly Ca, Si and K [18]. Conversely, Zevenhoven-Onderwater (2001) [17] did not conclude Si to be present as salt or free ion. Potassium is probably present as $\mathrm{KCl}$ in soluble salt in cell fluids [17]. In general, large variations in elemental composition exist between wood species [20] and between the wood and its bark [21], [20].

\subsubsection{Ligneous biomass}

Ligneous biomass, used as co-firing fuel in the Netherlands, comprises shells, hulls, pits and cake leftover after pressing of oil containing seeds. This biomass originates from the foodprocessing industry. From the KEMA database, average ash contents are: olive residues $7.5 \%$, cacao shells $8.4 \%$ and palm pit scales $5.0 \%$. K, Ca, P and Si are important ash forming elements in all ligneous biomass except for olive kernels; see [19] and [22]. Their chemical fractionation results show that for almond hulls and shells and olive pits, $\mathrm{Si}, \mathrm{Ti}, \mathrm{Al}$ and $\mathrm{Fe}$ are mainly present as mineral (and in case of olive kernels also $\mathrm{S}$ ). Furthermore, elements $\mathrm{K}, \mathrm{Na}, \mathrm{Ca}, \mathrm{Mg}$ and $\mathrm{P}$ in almond hulls and shells and olive kernels are to a certain extent ion exchangeable and hence concluded to be organically bound. The fractions are in the ranges $15-30 \%(\mathrm{~K}), 5-35 \%(\mathrm{Na})$, $20-35 \%(\mathrm{Ca}), 35-80 \%(\mathrm{Mg})$ and $5-15 \%(\mathrm{P})$. Elements $\mathrm{Cl}, \mathrm{S}, \mathrm{K}, \mathrm{P}$ and $\mathrm{Na}$ are largely present as water soluble salts.

\subsubsection{Herbaceous biomass}

Herbaceous biomass is straw, hay and grass. Straw is used as co-firing fuel in e.g. Denmark for the last three decades, but due to availability and price not in the Netherlands. The ash content in straw is on average 4.6\% [23]. Main elements in the ash are K, Si and Ca. Minerals comprise e.g. quartz and alumino-iron-silicates [24]. Organically bound elements are mainly sulphur, potassium and calcium in the solid organic matrix of the plant [24]. According to Kundsen et al. (2004), salts are e.g. $\mathrm{KCl}, \mathrm{KHCO}_{3}, \mathrm{CaCO}_{3}$ and $\mathrm{K}_{2} \mathrm{SO}_{4}$ [24], while Mlonka-Mędrala et al. (2020) also found $\mathrm{K}_{2} \mathrm{CO}_{3}$ [25]. Aqueous solutions consist of ions like $\mathrm{Ca}^{2+}, \mathrm{K}^{+}, \mathrm{HCO}_{3}{ }^{-}, \mathrm{Cl}^{-}, \mathrm{SO}_{4}{ }^{2-}, \mathrm{H}_{2} \mathrm{PO}_{4}^{-}$

and $\mathrm{R}-\mathrm{COO}$. The $\mathrm{pH}$ extraction results of Doshi (2007) show that all elements in straw, including the refractory elements $\mathrm{Si}$ and $\mathrm{Al}$, are present as free ions or salts for at least $40 \%$ [18]. Because straw is left on the land for shorter or longer periods of time, water soluble salts can leach out due to rain [26].

\subsubsection{Blends and mixtures}

Biomass pellets are used as fuel for co-firing in the Netherlands by E.ON Maasvlakte. They are produced by Biomass Nederland B.V. who process residual streams. The pellets consist of a 
mixture of up to 18 different biofuels like wood, paper sludge, composted sewage sludge, compost and bark of which the relative shares depend on factory input. This means that the composition of the pellets can vary a lot. Analyses from the KEMA biomass database show that biomass pellet ash consists mainly of refractory elements $\mathrm{Si}, \mathrm{Al}$ and $\mathrm{Fe}$, and also the Ca-content is high. In addition, the analysis of Tortosa Masiá et al. (2007) shows an elevated phosphor content [22]. Little is known and can be said about the speciation of elements in such a heterogeneous fuel. Availability is highest of $\mathrm{Ca}, \mathrm{S}$ and $\mathrm{K}$ of which $\mathrm{Ca}$ and $\mathrm{S}$ are predominantly organically bound.

\subsubsection{Animal derived biomass}

Animal fat contains almost no ash whereas analyses of Meat and Bone Meal (MBM) in the KEMA databank give an average of $20 \%$ which is much higher than the ash content in average coal fired in The Netherlands (10 - 15\%). Main elements in MBM ash are Ca and P. Refractory elements $\mathrm{Si}, \mathrm{Ti}, \mathrm{Al}$ and Fe are all low in concentration. Deydier et al. (2005) investigated MBM ashed with a variety of techniques [27]. Their conclusion is that this ash mainly consists of calcium $(30.7 \%)$ and phosphate $(56.3 \%)$ rich compounds, mainly a mixture of calcium hydroxyapatite, $\mathrm{Ca}_{10}\left(\mathrm{PO}_{4}\right)_{6}(\mathrm{OH})_{2}$ and tricalcium phosphate $\left(\beta-\mathrm{Ca}_{3}\left(\mathrm{PO}_{4}\right)_{2}\right)$ (characteristics of mineral phases of calcified tissues like bone ore teeth). Other mineral phases present are calcium deficient apatite $\left(\mathrm{Ca}_{10-x}\left(\mathrm{HPO}_{4}\right)_{x}\left(\mathrm{PO}_{4}\right)_{6-x}(\mathrm{OH})_{2-x}\right)$; carbonates were also observed, but in much lower intensity compared to phosphates, also carbonates are more abundant in ash $>250$ $\mu \mathrm{m}$ than in ash < $250 \mu \mathrm{m}$; also soil contaminants originating from browsing of grass such as quartz. Significant levels of sodium $(2.7 \%)$ and potassium $(2.5 \%)$ were detected, present in the forms $\mathrm{NaCl}$ and $\mathrm{KCl}$. The latter could also be concluded from the fact that $\mathrm{K}$ is all water soluble and hence present as soluble salt or free ions; $\mathrm{Na}$ is mainly water soluble, hence present as soluble salt whereas the remaining fraction is ion exchangeable, hence organically bound.

\subsection{Fate of mineral matter}

\subsubsection{Fate of mineral matter in coal combustion}

In pulverized fuel combustion, heating rates are in the range of $10^{3}-10^{5} \mathrm{~K} / \mathrm{s}$ [28]. The highest temperature of the particles which is reached depends on the type of the boiler, the amount of excess air, the load, the diameter of the particles and whether a particle is a burning char particle or an excluded mineral. The highest temperature varies between 1,300 and $1,700{ }^{\circ} \mathrm{C}$ [28] where large particles can have a temperature of $200 \mathrm{~K}$ lower than the small particles $(<1 \mu \mathrm{m})$ which attain the flame temperature [9]. The temperature of a burning char particle can be as high as around $2,000{ }^{\circ} \mathrm{C}$ [29] which is above the melting points of most mineral species. The peak flue gas temperature is reached in the active combustion zone near the burners. The boiler has a Furnace Gas Exit Temperature (FGET) (also called 'end of furnace temperature') limited at about 
$1,050-1,175^{\circ} \mathrm{C}$ (depending on design of the boiler) to overcome slagging of the water walls and superheaters at full load. At the boiler outlet, flue gas temperatures are $300-375{ }^{\circ} \mathrm{C}$ and when the boiler is operated in part load, temperatures will be lower, down to approximately $200{ }^{\circ} \mathrm{C}$. The residence time in the furnace of a boiler is between $1-3$ seconds. 1 second is given for instance by Baxter (1993) [30] which holds for older boilers with a lower burnout. In newer boilers, residence time is longer to obtain a higher burnout. Pressure in the boiler is atmospheric or somewhat below to overcome risks related with steam in case of tube failure as well as the dispersion of toxic combustion products like CO. Reducing conditions apply in the combustion zone with low-NOx (staged) combustion. Excess air is supplied at the over fire air (OFA) ports and downstream conditions are oxidizing (although the local oxygen content may be low due to insufficient mixing).

A graphical overview of ash formation in pulverized coal combustion is given in Figure 2.2. Coalescence of included minerals and fragmentation of excluded minerals are the two important mechanisms governing ash formation for high-rank coals while vaporization and condensation account for about $1 \%$ of the ash formation [29]. 


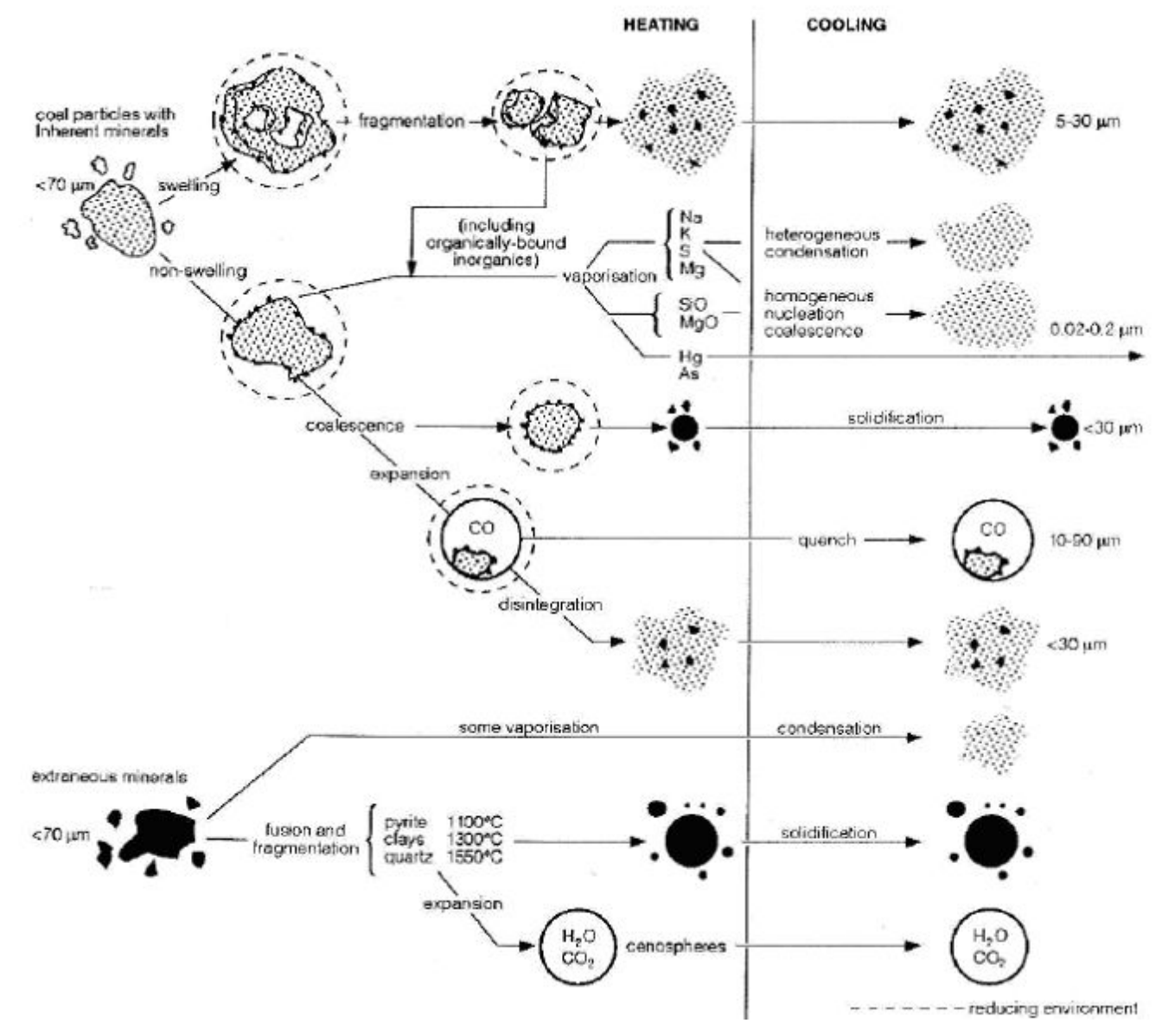

Figure 2.2 Mechanisms involved in fly ash formation; source: [2]

Included mineral matter reaches peak temperatures above the gas temperature due to exothermic reactions in the char. Several processes occur to the mineral matter during combustion, amongst are swelling, fragmentation, coalescence, fusion, vaporisation, and (re)condensation. These processes can take place simultaneously or sequentially, dependent on e.g. the local (chemical) environment and the temperature history of a particle. Early mechanisms in ash formation involve softening, fusion and (partial) volatilisation. Particle swelling is dependent on the plasticity of the heated particles and occurs when with devolatilization the pores of a particle get blocked due to plastic flow, trapping the volatile matter to form bubbles. Finally, the particle can burst and fragments. Fragmentation, in general, includes all mechanisms that produce more than a single ash particle form a char particle. Inorganics vaporize depending on their speciation whereby mineral matter that is organically bound all vaporizes. Molten particles may coalesce producing more or less spherical particles with a diameter $<30 \mu \mathrm{m}$. When bubbles are formed within these particles, hollow spherical shapes up to $250 \mu \mathrm{m}$ can be formed which are called cenospheres (almost complete spheres) or plerospheres (part or side of 
sphere). These relatively large formations are important and can capture smaller particles on their surface [2].

Excluded minerals reach a temperature slightly below the flame temperature which depends on particle size and trajectory relative to the combustible matter [1]. Some of the minerals vaporize and condense during cooling. Depending on the type of mineral it fuses at a certain temperature, see next section. Whether fragmentation occurs depends on the chemical composition and physical morphology. Hurley and Schobart (1993) indicate that pyrite may fragment during the early stages of burnout as well as carbonates as a consequence of decomposition (calcination) [31]. In a later stage in combustion, quartz and iron oxide particles can fragment [32].

\subsubsection{Mineral transformations}

According to Baxter et al. (2001) [33] many inorganic materials occur as hydrates in coal which dehydrate during combustion. This is an endothermic reaction, often consuming more energy than vaporizing the water alone, which takes place generally between 100 and $200{ }^{\circ} \mathrm{C}$ [33]. With further heating, mineral transformations occur; the transformations of major and minor minerals are summarized in Figure 2.3 based on several mineral transformation studies (which have their limitations ${ }^{2}$, apart from heating rate [34]), see Figure 2.3. The transformation of major minerals and pyrite is reviewed in the following.

\footnotetext{
2 Mineral transformations are often researched by ashing coal, preferably at low temperature, heating the ash under air and quenching it at a certain temperature. It should be noticed that the study of mineral transformation is limited by the facts that mineral transformations and devolatilization occur during preparing laboratory ash, transformations occur during quenching and heating rates and conditions (e.g. gas composition) do not match those in the boiler. However, regarding heating rate, Stinespring et al. (1977) [34] found that, except for pyrite, similar results were obtained with the aforementioned method and with generating ash in a combustor with a high heating rate.
} 


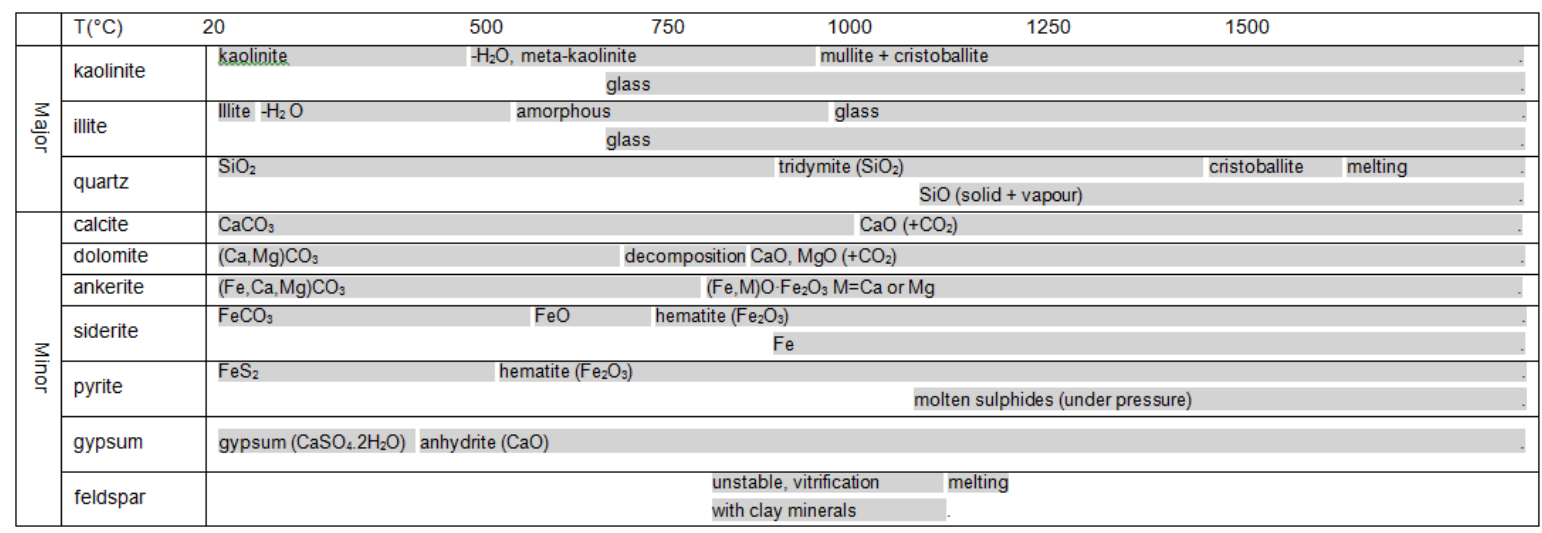

Figure 2.3 Summary of mineral transformations during heating from [1], [35], [36] and [37]. Differentiation between oxidizing and reducing conditions is made where the lower bar features reducing conditions.

Kaolinite experiences several mineral transformations during heating [38], [39]. At $100-200{ }^{\circ} \mathrm{C}$ first dehydration starts and at $400-600{ }^{\circ} \mathrm{C}^{3}$ hydroxyl groups between the silicate layers leave the structure and meta-kaolinite is formed which is stable up to $950-1,000{ }^{\circ} \mathrm{C}$. Meta-kaolinite is a more or less amorphous phase. Between 925 and $1,000{ }^{\circ} \mathrm{C}$ meta-kaolinite transforms into a spinel of a $y$-alumina form. Between 1,100 and $1,200{ }^{\circ} \mathrm{C}$ the spinel transforms into mullite (and cristoballite). Mullite is a phase, found to be stable up to $1500{ }^{\circ} \mathrm{C}$ in High Temperature Ashing (HTA). Vassilev et al. (2003) found kaolinite as minor to major phase in fly ash and mullite as major phase [40]. With slagging and fouling, some positive effects were found. It increases ash fusibility temperatures [41] and raises viscosity of melt [42]. Alkalis can be adsorbed on the kaolinite surface followed by diffusion into the particles and reaction with the aluminium silicate structure [38]; Glazer (2006) showed an increase (in rate and in proportion) of potassium uptake in kaolin particles with steam (water) in the gas phase [43].

Illite is not a mineral but a general term for clays with a composition similar to muscovite, chemical formula $\mathrm{KAl}_{2}\left(\mathrm{Si}_{3} \mathrm{Al}\right) \mathrm{O}_{10}(\mathrm{OH})_{2}$, except for less $\mathrm{K}^{+}$and more $\mathrm{SiO}_{2}$ and $\mathrm{H}_{2} \mathrm{O}$. Impurities as $\mathrm{Fe}$ and $\mathrm{Mg}$ occur, as well as $\mathrm{Na}$. At $600-700{ }^{\circ} \mathrm{C}$ hydroxyl groups leave the structure. Between 850 and $900{ }^{\circ} \mathrm{C}$ the illite lattice structure decomposes [44]. Melting begins at $927{ }^{\circ} \mathrm{C}$ and proceeds up to $1,102{ }^{\circ} \mathrm{C}$ [45]. Srinivasachar et al. (1990) found that the illite was completely molten above approximately $1,123{ }^{\circ} \mathrm{C}$ to produce a glass phase [46]. No other phases were found, whereas Gupta et al. (1998) also mention the formation of a spinel at decomposition of the illite lattice, dissolving in the glass at $1,300{ }^{\circ} \mathrm{C}$ and also transformation of the spinel to mullite at

3 The dehydration was described more in detail by Baxter et al. (2001) [38] which indicate formation of meta-kaolinite at $400-600^{\circ} \mathrm{C}$ rather than $550-600^{\circ} \mathrm{C}$ as given by Sinespring et al. (1977) [39] 
$1,100-1,400{ }^{\circ} \mathrm{C}$ [39]. Bryers (1996) states that glass particles in fly ash are primarily formed by fluxing between different minerals (as the melting temperatures of different minerals exceeds the temperatures experienced by particles in pc combustion), however, illite (and biotite) are exceptions to this and produce low melting glasses [1]. Srinivasachar et al. (1990) researched illite transformations during pulverized coal combustion conditions and concluded that $\mathrm{K}$ in illite does not vaporize - vaporized $\mathrm{K}$ (in pc combustion) results from organically bound potassium [46]. They also found that illite coalesced with other minerals (kaolinite, quartz, pyrite). The role in slagging is that it is implicated as source of molten ash. $\mathrm{K}$ and $\mathrm{Fe}$ impurities in illite work as fluxing agents; in general illite forms low melting glass particles. Deposition tests of Srinivasachar et al. (1990) showed deposition of illite particles with a furnace temperature above $1,123^{\circ} \mathrm{C}$ (gas temperatures at the deposition site were about $\left.1,023^{\circ} \mathrm{C}\right)[46]$.

Quartz $\left(\mathrm{SiO}_{2}\right)$ undergoes two (structural) transformations within the solid phase when heated. First there is the transformation from quartz to trydimyte $\left(876{ }^{\circ} \mathrm{C}\right)$ and then to cristoballite $(1,470$ $\left.{ }^{\circ} \mathrm{C}\right)$. With coal combustion these changes are only experienced to a minor extent. According to Gupta et al. (1998), the presence of iron, potassium or calcium oxide may cause the silicate to form a glass at a temperature below $1,300{ }^{\circ} \mathrm{C}$ and eventually cause as much quartz to dissolve until the glass is saturated with silica [39]. Melting points are as follows: quartz $1,610{ }^{\circ} \mathrm{C}$, trydimyte $1,703^{\circ} \mathrm{C}$, cristoballite $1,723+/-5^{\circ} \mathrm{C}$.

Pyrite $\left(\mathrm{FeS}_{2}\right)$ is a combustible mineral and ignition temperatures as low as $450{ }^{\circ} \mathrm{C}$ have been reported [1]. When heated, pyrite initially decomposes to pyrrhotite $\left(\mathrm{Fe}_{0.877} \mathrm{~S}\right)$ which oxidizes. The oxidation of pyrite is an extremely complex process, Schmuk (1960) considered 13 primary potentially reactions and another 15 secondary reactions of which reaction products are $\mathrm{FeO}$, $\mathrm{FeS}, \mathrm{Fe}_{2} \mathrm{O}_{3}, \mathrm{Fe}_{2}\left(\mathrm{SO}_{4}\right)_{3}, \mathrm{~S}, \mathrm{SO}_{2}, \mathrm{SO}_{3}$ [47]. An Fe-O-S melt forms, a phase diagram of the $\mathrm{Fe}-\mathrm{O}-\mathrm{S}$ system is given in Figure 2.4 . 


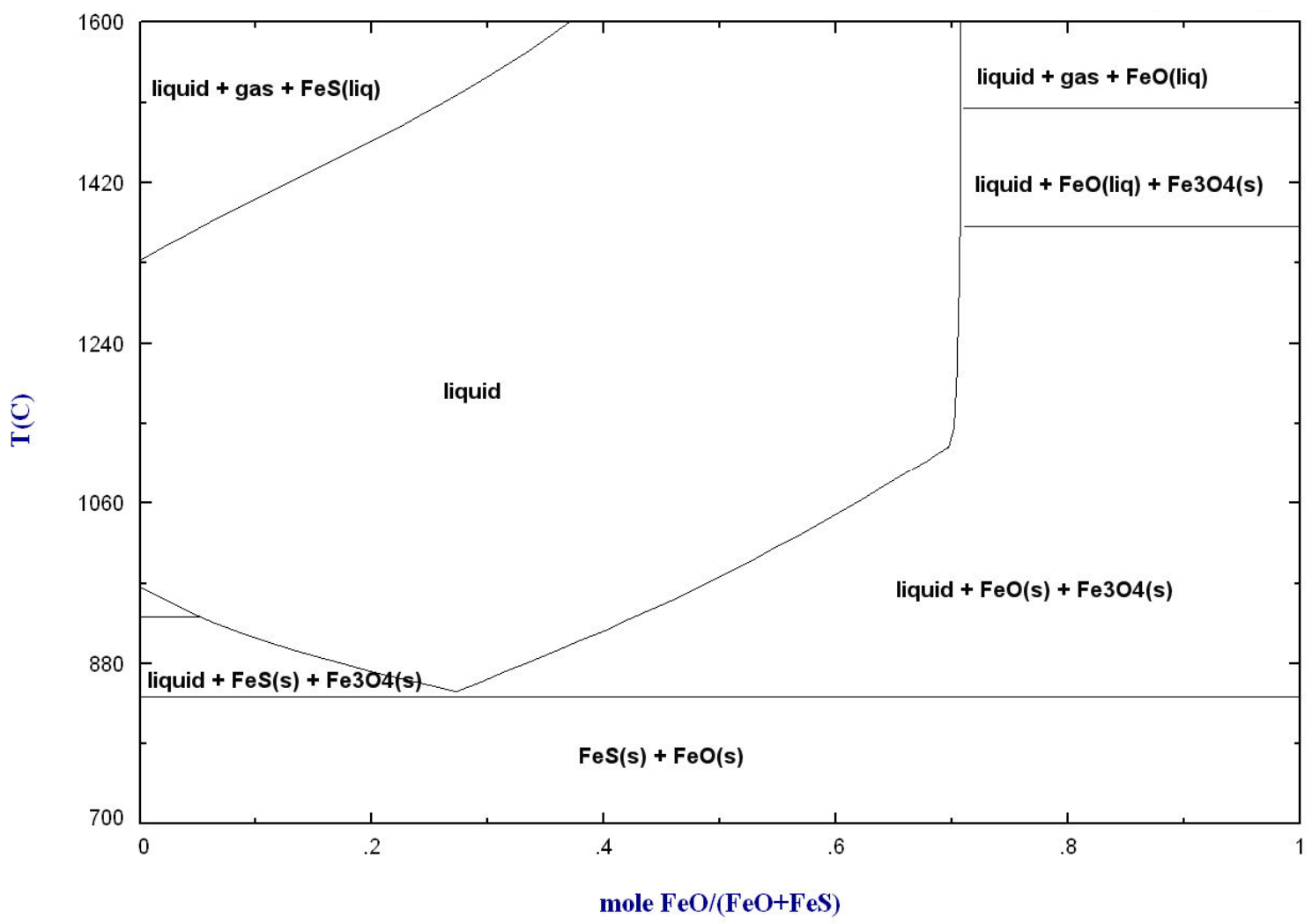

Figure 2.4 Phase diagram of Fe-O-S system; calculated with FactSage 5.5.

Crystallization of magnetite $\left(\mathrm{Fe}_{3} \mathrm{O}_{4}\right)$ starts when the $\mathrm{Fe}_{2} \mathrm{O}_{3}$ content exceeds 85\% [48]. At longer residence time in their test also hematite $\left(\mathrm{Fe}_{2} \mathrm{O}_{3}\right)$ crystallized. This mineral has a melting temperature of $1,540{ }^{\circ} \mathrm{C}$ and is of little consequence in ash deposition, except as aggregate or a fluxing agent to other deposited species [1]. The melting phase exists until almost all magnetite is crystallized. Deposition tests of pyrite particles were performed by Srinivasachar et al. (1990) [48]. A high capture efficiency (up to a $100 \%$ ) due to inertial impaction of burning pyrite particles on a substrate was seen at low residence times available for oxidation before impaction on the tubes (were according to reaction kinetics a liquid phase was present) while at higher residence times (without liquid phase) the capture efficiency drops to $0 \%$. 


\subsubsection{Fate of organically bound inorganic matter and water soluble salts}

\section{Sodium}

Organically bound sodium and sodium present as water soluble salt will readily vaporize whereas clay bound sodium will not vaporize [49]. The largest part of $\mathrm{Na}$ in high-alkali coal was found to be organically bound [50]. According to Lindner et al. (1991) [51] $]^{4}$, organically bound sodium:

- is released under reducing conditions as metallic sodium;

- the rate of release depends on total surface, pore size, pore diffusivity and bulk diffusivity;

- when all volatiles have been released, so has the sodium;

- sodium in the gas phase forms sodium hydroxide $(\mathrm{NaOH})$.

Findings on $\mathrm{NaCl}$ are similar and comprise:

- release of volatile sodium starts at $750{ }^{\circ} \mathrm{C}$; melting of $\mathrm{NaCl}$ occurs at $801^{\circ} \mathrm{C}$

- rate of release increases above $750{ }^{\circ} \mathrm{C}$ and depends also on bulk diffusivity (controlling mechanism for crystals $<0.1 \mu \mathrm{m}$ ) and pore diffusivity (controlling mechanism for crystals > $0.3 \mu \mathrm{m})$. Evaporation rates are similar to the devolatilization;

- sodium in the gas phase forms sodium hydroxide $(\mathrm{Na}(\mathrm{OH}))$.

Sodium can also be present as other gas species such as $\mathrm{NaCl}$ (see Figure 2.5) and [49] calculated with equilibrium calculations that at $1,400 \mathrm{~K}, 75 \%$ of the sodium is present as $\mathrm{NaCl}(\mathrm{g})$. Lindner and Wall (1990) investigated the reaction between sodium and included silica and kaolin with drop tube furnace experiments with prepared coal samples [52]. Their findings are that the formation rate of sodium silicate increases with temperature but it is limited by agglomeration/coalescence reducing the surface area available for reaction. Furthermore, sodium silicate(s) interactions decrease with presence of $\mathrm{Cl}$ and $\mathrm{S}$, more with kaolin than with quartz. Also, they found that $\mathrm{NaCl}$ interaction with kaolin is much higher than with quartz (and therefore seems more interesting as additive). Lindner et al. (1991) investigated the reaction of sodium with silicates more in detail [51]. The reaction to form silicates comprises five steps (quoted from [1]) which are shown in Figure 2.5:

1 Transportation of gaseous reactants and products in the char/boundary

2 Diffusion of gaseous reactants and products through the pores of the char

3 Reactions at the sodium silicate melt surface

4 Diffusion through the silicate melt

5 Sodium silicate forming reactions at the silicate/silica interface.

The controlling mechanism (boundary layer transport, diffusion) depends on the stage of the reaction. The scheme suggests that reaction between sodium and aluminosilicates occur after sodium escapes the char particle. Silicates can be responsible for very high temperature slagging and fouling (i.e. $>954^{\circ} \mathrm{C}$, see [1]).

\footnotetext{
${ }^{4}$ Information was obtained from [1] as [51] is a conference paper that could not be obtained from the authors.
} 


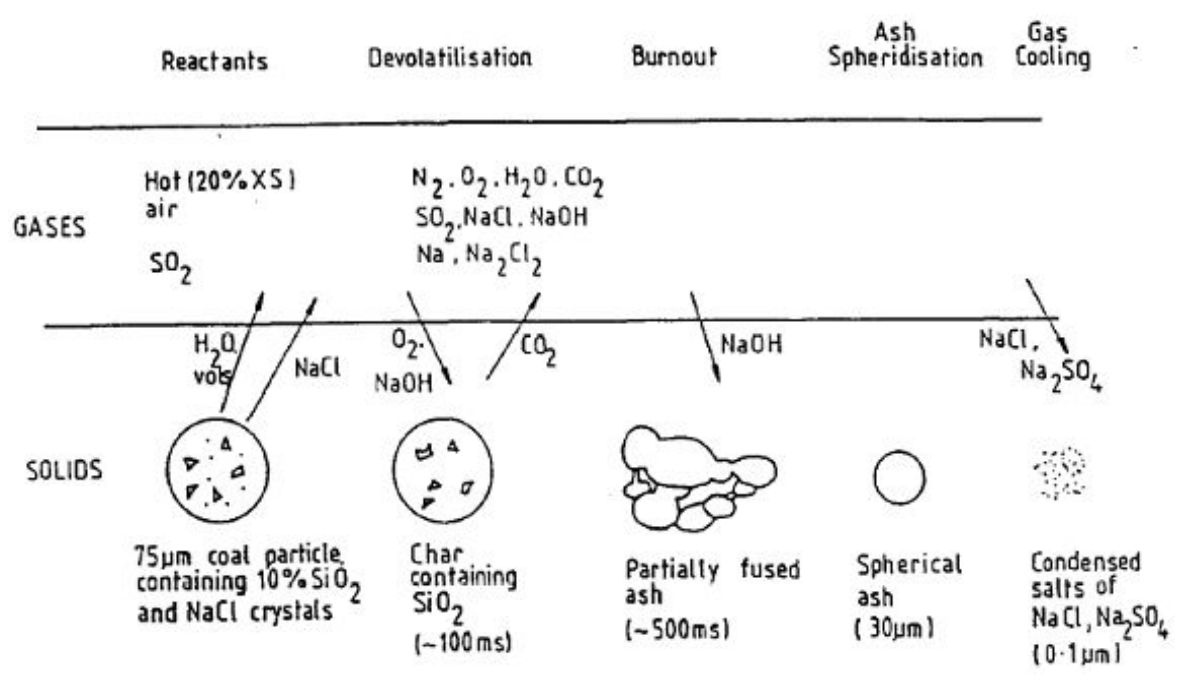

Figure 2.5 Mechanisms of $\mathrm{Na}$ ash reactions. Source: [51].

As the gas cools, $\mathrm{NaOH}$ converts to $\mathrm{NaCl}$ and $\mathrm{Na}_{2} \mathrm{SO}_{4}$ with low melting points of $801{ }^{\circ} \mathrm{C}$ and 884 ${ }^{\circ} \mathrm{C}$, respectively.

\section{Calcium}

Organically bound calcium is known to produce a fume of reactive submicron $\mathrm{CaO}$ as well as calcium silicate cenospheres [1]. However, the release of calcium is not studied in detail. Bryers (1996) reports the initiation by the reactive calcium fume of calcium sulphate deposits on furnace walls and in the convective area [1]. Helbe et al. highlight the involvement of organically bound calcium which reacts with minerals to form calcium-alumino-silicate phases (in relation to low rank coals) [53].

\subsubsection{Particle size distribution}

Classical theory states that particle size distribution (PSD) of fly ash particles is bi-modal: one mode centred at $0.1 \mu \mathrm{m}$, which originates from vaporization and condensation, and one mode centred at $20 \mu \mathrm{m}$ originating from course particle fragmentation. Vaporization and fragmentation are clearly shown in Figure 2.6. 


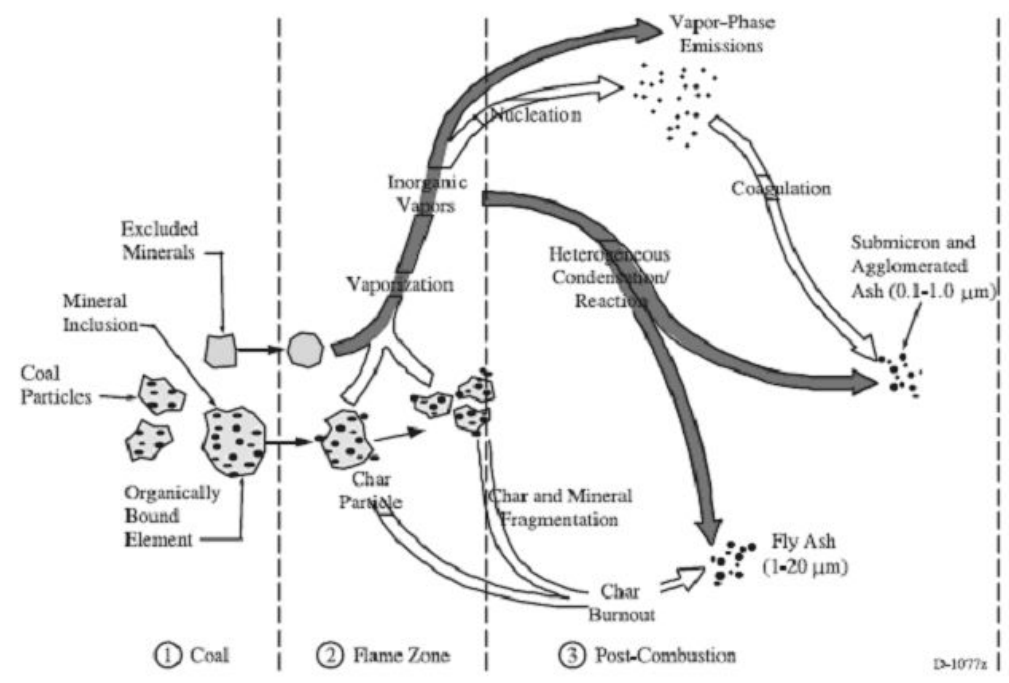

Figure 2.6 Partition mechanisms in coal combustion; source: [54]

However, newer insights clearly show that the PSD is rather tri than bi-modal [55]. A summary of the findings of [55] and [54] is given in Table 2.2. In spite of these findings the idea of the trimodal PSD is doesn't seem to be generally accepted.

Table 2.2 Mode, origin and mode of occurrence of coal fly ash particles

\begin{tabular}{|c|c|c|}
\hline mode & origin & mode of occurrence \\
\hline $0.08-0.1 \mu \mathrm{m}$ & vaporization, nucleation and growth & primarily spherical \\
\hline $0.7-3.0 \mu \mathrm{m}$ & fine fragmentation & $\begin{array}{l}\text { no dominant type but spheres most common; most } \\
\text { spheres show signs of stretching and deforming, } \\
\text { so a high specific surface area }\end{array}$ \\
\hline $20 \mu \mathrm{m}$ & $\begin{array}{l}\text { course fragmentation } \\
\text { agglomeration }\end{array}$ & $\begin{array}{l}\text { spheres with smooth surface area (probably } \\
\text { aluminosilicates) and crystalline agglomerations } \\
\text { (probably pyrite). }\end{array}$ \\
\hline
\end{tabular}

\subsubsection{Fate of mineral matter in biomass co-combustion}

The fate of mineral matter in biomass co-combustion is not different from pulverized coal combustion. However, mineral matter in coal consists mainly of minerals and in biomass it consists of salts and organically bound inorganics. Therefore, the extent to which inorganic material in biomass vaporizes is much higher. The interaction of vaporized alkalis with coal minerals during combustion is topic of this thesis. In sections 2.3.1.1 and 2.3.1.2 the reaction of 
alkalis with kaolinite and inherent silica is discussed. The remaining vapour will condense homogeneously or heterogeneously. Vaporization and condensation are discussed in the following.

\subsubsection{Vaporization}

The inorganic matter in biomass - mostly embedded in the fuel - is released by three mechanisms: vaporization, inorganic reaction and organic reaction, [19]. Vaporization may depend on the local conditions (oxidizing or reducing) and the amount of $\mathrm{Cl}$ and $\mathrm{S}$ present. Potassium (K), chlorine $(\mathrm{Cl})$ and sulphur $(\mathrm{S})$ but also $\mathrm{Na}, \mathrm{Ca}, \mathrm{Mg}$, are vaporised to a large extent. A literature review on release of $\mathrm{K}, \mathrm{Cl}$ and $\mathrm{S}$ during pyrolysis and combustion has been performed by Johanson et al. (2011) [56], which is summarized in the following.

Several $\mathrm{K}$ transformations can take place during devolatilization and char burnout [57], see Figure 2.7, primarily at higher temperatures. Transformation from inorganic to organic $\mathrm{K}$ can take place during initial devolitalization as the organic matrix decomposes [58, 59]. Dominant transformations at higher temperature are $\mathrm{KCl}$ sublimation and reaction with aluminosilicates. The latter reaction is influenced by the availability of $\mathrm{Si}, \mathrm{Cl}, \mathrm{Ca}$ and $\mathrm{Mg}$ [58,60,61,62, 63]. A small amount of $\mathrm{K}(<10 \mathrm{wt} \%)$ can be released to the gas phase at lower temperature $(<600-$ $700{ }^{\circ} \mathrm{C}$ ) which is related to thermal decomposition of the organic matrix [57, 58,60]. The main release route of $\mathrm{K}$ (see e.g. [57]) and $\mathrm{Na}$ (see e.g. [64]) is through $\mathrm{KCl}$, respectively $\mathrm{NaCl}$ sublimation); other release pathways (in order of decreasing significance) are dissociation of carbonates, sulphates and silicates $[60,65,66]$. 


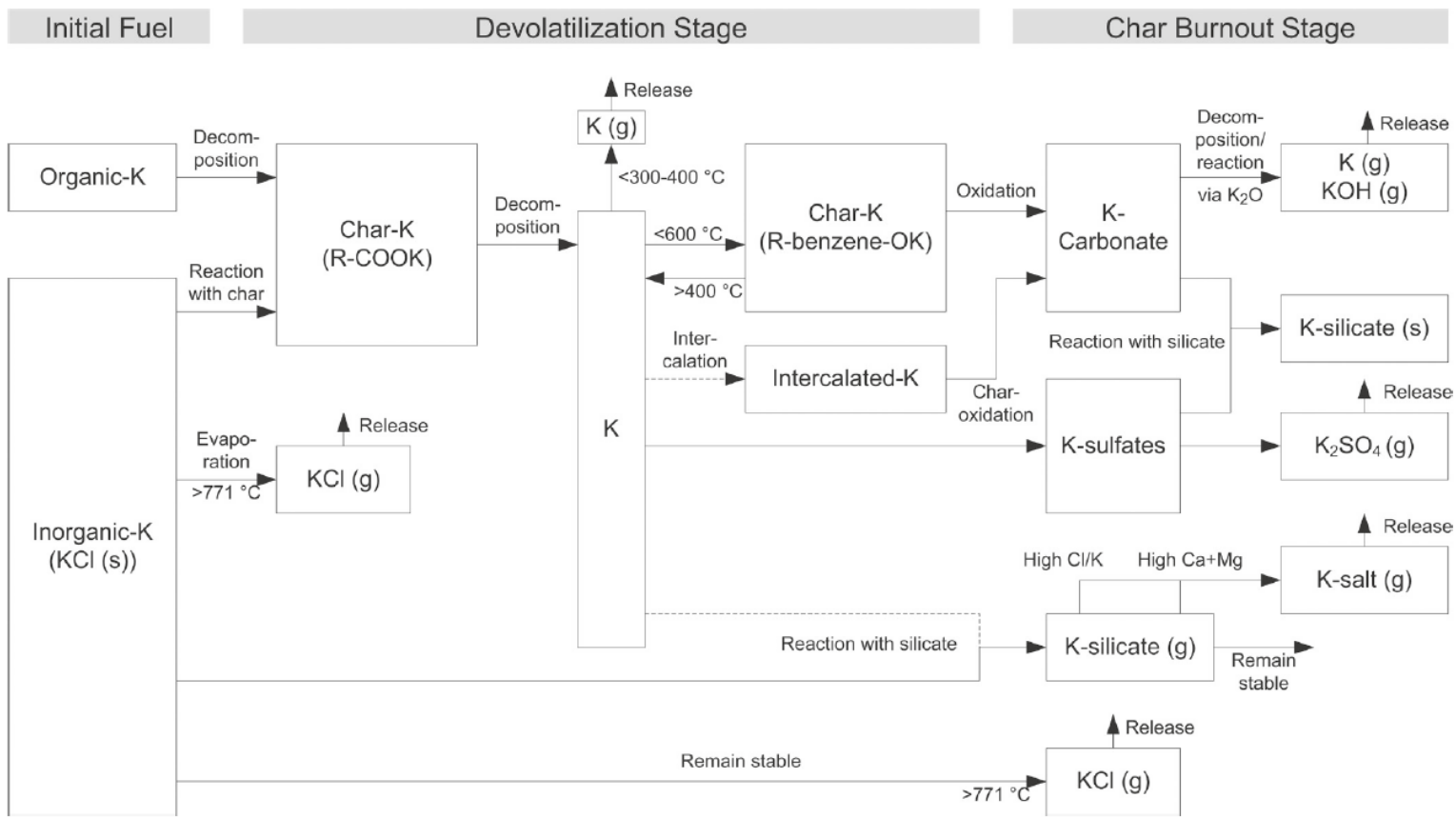

Figure 2.7 Possible reaction paths and release mechanisms of $\mathrm{K}$ during devolatilization and combustion, with special emphasis on the combustion of annual crops; source: [56].

An overview of transformations and release of $\mathrm{Cl}$ is shown in Figure 2.8. $\mathrm{Cl}$ is release in two steps: at low temperature and at high temperature. Already high levels $(20-50 \%)$ of $\mathrm{Cl}$ have been detected at temperatures as low as $300-400{ }^{\circ} \mathrm{C}$ [67]. $\mathrm{Cl}$, initially present as $\mathrm{KCl}$, can react with functional groups in the organic matrix, e.g. by the following reaction [68]:

$R-\operatorname{COOH}(s)+\operatorname{KCl}(s) \rightarrow R-\operatorname{COOK}(s)+\operatorname{HCl}(g)$

$\mathrm{HCl}$ can also be released through tar associated $\mathrm{Cl}$. In both cases, the released $\mathrm{HCl}$ can be recaptured by metals in the char, forming metal chlorides $[57,69] . \mathrm{KCl}$ is the dominant $\mathrm{Cl}$-species in biomass and at higher temperatures $\left(700-800^{\circ} \mathrm{C}\right) \mathrm{Cl}$ can be released by sublimation of $\mathrm{KCl}$. Alternatively, a reaction with aluminosilicates can occur at higher temperature, and $\mathrm{Cl}$ may be released in the form of $\mathrm{HCl}$ by the reaction:

$2 \mathrm{NaCl}(g, l)+\mathrm{H}_{2} \mathrm{O}(g)+x Y(s) \leftrightarrow \mathrm{Na}_{2} \mathrm{O} \cdot x Y(s, l)+2 \mathrm{HCl}(g)$

Where $Y(s)$ is a pure silica phase, a pure alumina phase of an aluminosilicate $[62,63]$. 


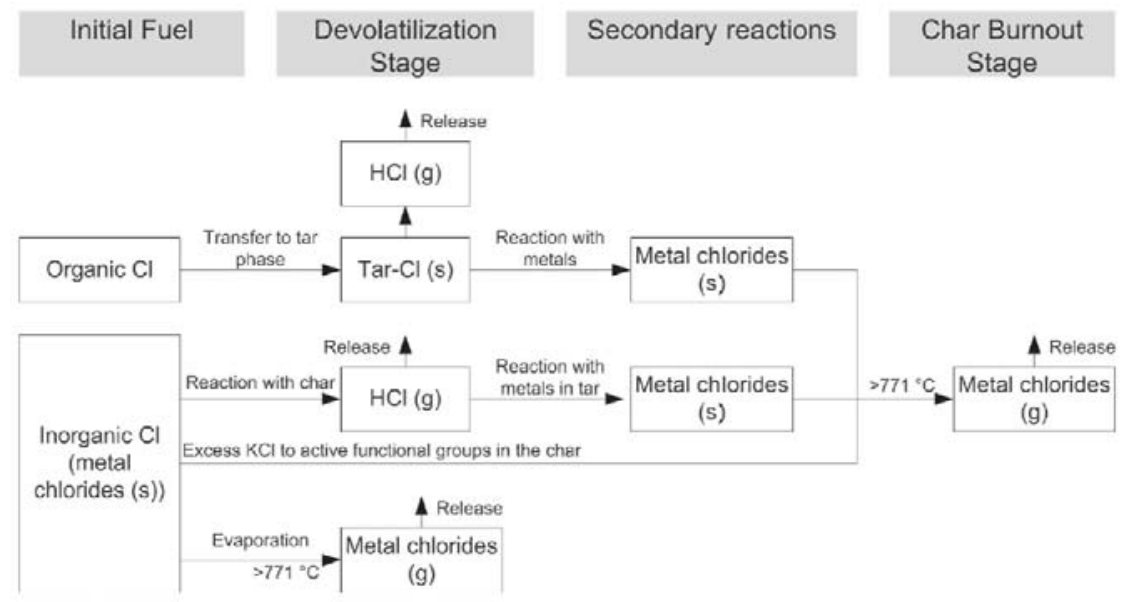

Figure 2.8 Possible reaction paths and release mechanisms of $\mathrm{Cl}$ during devolatilization and combustion, with special emphasis on the combustion of annual crops; source: [56].

An overview of transformations and release of $S$ is shown in Figure 2.9. Organically bound $S$ releases at low temperatures, probably starting below $200{ }^{\circ} \mathrm{C}$, since the decomposition temperatures of the two most important S-containing precursors for plant protein, cystein and methionine, are $178{ }^{\circ} \mathrm{C}$ and $183^{\circ} \mathrm{C}$, respectively [56]. This released $\mathrm{S}$ can be recaptured by the char, after which it can again be re-released during char burnout or react with metals to form metal sulphates. Inorganically bound $S$ (metal sulphate) is retained in the ash until the combustion temperature exceeds approximately $900{ }^{\circ} \mathrm{C},[60,68,70]$. However, [56] also indicate that during devolatilization, sulphates can react with $\mathrm{CO}$ forming $\mathrm{SO}_{2}(\mathrm{~g})$ already at $700{ }^{\circ} \mathrm{C}$. Also, reaction with $\mathrm{CO}$ can transform metal sulphates into metal sulphides. Metal sulphates and sulphides can evaporate or decompose above $1,150{ }^{\circ} \mathrm{C}$, releasing sulphur. Decomposition can be due to reaction with silicates, where the cation is incorporated in the silicate melt. 


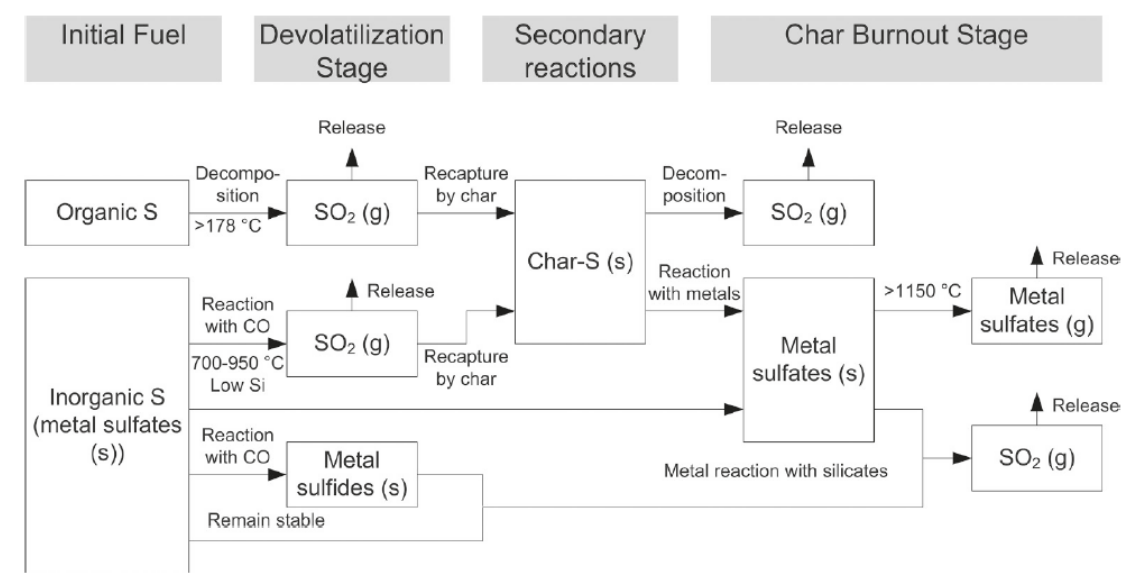

Figure 2.9 Possible reaction paths and release mechanisms of $\mathbf{S}$ during devolatilization and combustion, with special emphasis on the combustion of annual crops; source: [56].

In the gas phase, reactions may take place and during cooling, heterogeneous and homogeneous condensation takes place. This results in fine ash particles, sometimes to be assumed the major source of fine ash in CFB combustion [71].

\subsubsection{Homogeneous condensation}

Homogeneous condensation is particle formation by nucleation from a gas phase. The consecutive steps of converging gas molecules, critical nucleus formation and particle growth are set out in Figure 2.10.

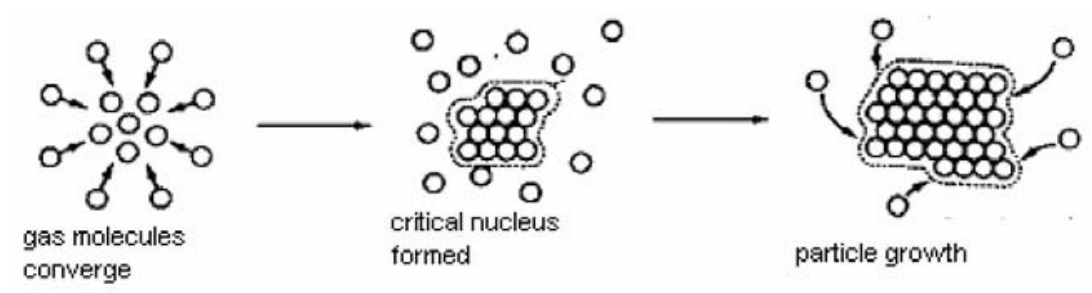

Figure 2.10 Homogeneous condensation; source: [72].

The thermodynamics of homogeneous nucleation is recapitulated by A. Philipse in [73]. A nucleus can be represented by a model as being a collection of bulk molecules and surface molecules, see Figure 2.9. 


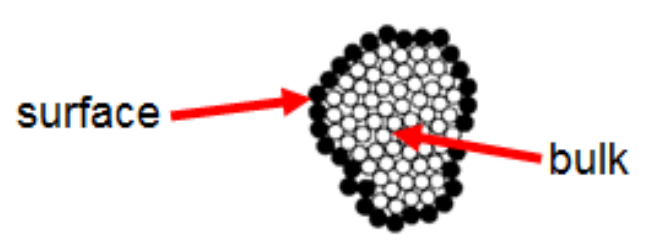

Figure 2.11 Model of nucleus consisting of a bulk of molecules and surface molecules; adapted from [73].

The Gibbs free energy of a nucleus can, analogously, also be represented as consisting of a bulk part and a surface part. Hence, $G=G_{b u l k}+G_{\text {surface }}$. Now, the non-equilibrium situation is considered where there is supersaturation of the gas phase: the activity $a>a_{S A T}$. Thereby $N$ molecules will be transferred from the gas phase to the nucleus. The change of Gibbs free energy is hence $\Delta G=\Delta G_{\text {bulk }}+\Delta G_{\text {surface }}$. The bulk term represents the driving force and is hence negative: $\Delta G_{b u l k}=-N k T \ln \frac{a}{a_{S A T}}=-N k T \ln S$, with $S$ the saturation ratio. The surface term represents the positive work which has to be done against expansion of the interface: $\Delta G_{\text {surface }}=\gamma A$, with $\gamma$ the surface energy density and $A$ the surface area. Hence:

$\Delta G=-N k T \ln S+\gamma A$

For a spherical particle can be written [18]:

$\Delta G=-\frac{4}{3} \pi r^{3} \rho \frac{R T}{M} \ln S+\gamma 4 \pi r^{2}$

Equation 2.4 shows that for small clusters (radii) the surface term dominates, also see the "example line" in Figure 2.12. At a certain point, the surface term and bulk term are equal, i.e. at the point that $\Delta G$ has reached a maximum (see Figure 2.12 , at radius $=a^{*}$ ). This maximum is the activation barrier in the formation of colloidal particles by homogeneous nucleation in a supersaturated solution or vapour [73]. It can also be seen from Equation 2.3 that the bulk term is proportional to the logarithm of the saturation ratio so with increasing $S$ the activation barrier is lower (see Figure 2.12). 


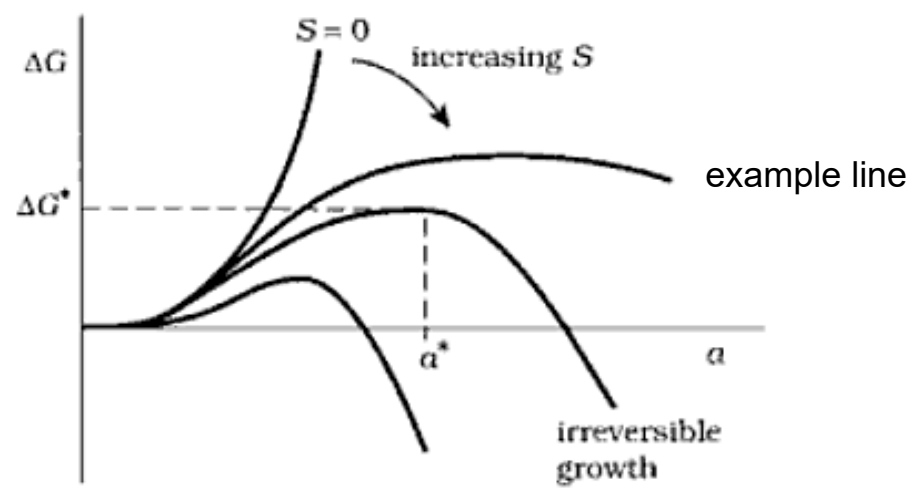

Figure 2.12 Nucleation and growth of a spherical particle with radius a in a solution with supersaturation ratio S; source: [73].

The saturation ratio of a mixture can be higher than the ratio of the individual species. This means that nuclei of a mixture can precipitate even when the vapour is not supersaturated with respect to the individual species.

\subsubsection{Heterogeneous condensation}

Heterogeneous condensation is referred to as the condition where molecules from the gas phase precipitate on existing nucleation sites. These sites are also called seeds and hence it is spoken of seeding nucleation. The nucleation sites in combustion can be for example fly ash particles or just homogeneously condensed particles, or heat exchanging surfaces. The kinetics of precipitation dramatically change with the increase of the number of nucleation sites, which the reader may verify by adding sugar or sand to a bottle of champagne.

The energy barrier for heterogeneous nucleation (in case of a positive contact angle) is much lower than for homogeneous nucleation and hence happens more easily. The change in Gibbs free energy is described with the same formula as for homogeneous nucleation, but multiplied with a function depending on the contact angle $\theta$, see Equation 2.5). A comparison of Gibbs free energy for heterogeneous and homogeneous condensation versus particle radius at a certain contact angle is given in Figure 2.13.

$\Delta G_{\text {heterogeneous }}=\Delta G_{\text {homogeneous }}\left(\frac{1}{2}-\frac{3}{4} \cos \theta+\frac{1}{4} \cos ^{3} \theta\right)$ 


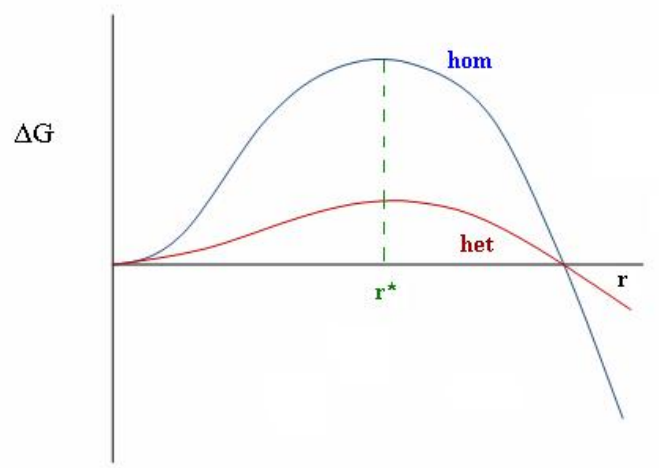

Figure 2.13 Free Gibbs energy with heterogeneous nucleation compared to homogeneous nucleation; source: [74].

\subsubsection{Co-combustion cases}

Co-combustion of straw

Final conclusions of the PhD thesis of Andersen titled "Deposit Formation during Coal-straw CoCombustion in a Utility PF-Boiler", see [23] are:

- the changes in fouling deposit formation observed due to co-combustion are operationally manageable when the sootblowing frequency is adequate, even though the amounts and tenacity of the upstream deposits increase;

- the slagging deposit formation was experienced to increase during coal-straw co-combustion, and it is thus necessary to monitor this and maintain a proper sootblowing frequency in the furnace;

- the major part of the $\mathrm{K}$ from the straw is bonded in K-Al-silicate particles, which participates in the deposit formation, but did not lead to more problematic deposits;

- the only K-salt of significance in the deposits is $\mathrm{K}_{2} \mathrm{SO}_{4}$.

\section{Co-combustion of wood}

Little operating experience on co-firing of wood has been published. Results from pilot-scale test facilities and full scale tests vary: no change, increasing or decreasing problems [75]; [76]; [77]. An attempt to use standard fusibility correlations to evaluate the influence of co-firing wood on boiler slagging gave non-equivocal results [75].

According to Bryers (1996), blending of wood with high sulphur fuel almost ensures fouling by calcium sulphate bonded deposits as the sulphur reacts with the submicron calcite particles at the tube surface [1]. Skrifvars et al. (2004), on the other hand, found that deposition rates in a 
wood fired boiler decrease when adding up to $0.1 \%$ of elemental sulphur to the furnace [78]. The deposits were more enriched in sulphur but apparently less prone to stick to the heat exchanging surface. The reason is not clear but an explanation could be sulphating of the wood ashes which in turn would decrease its stickiness. In addition, a decrease of the deposition rate was also found with adding up to $5 \%$ of peat which might be caused by the eroding (cleaning) effect.

\subsection{Deposition build-up and removal mechanisms}

A number of deposition mechanisms have been identified and described by various researchers which include:

- Particle related deposition

- $\quad$ sticking of impacting particles (distinction between large and intermediate particles) (IP)

- $\quad$ thermophoresis (TH)

- $\quad$ eddy diffusion (ED)

- Brownian diffusion (BD)

- Gas phase related deposition

- condensation (CO)

- $\quad$ heterogeneous reaction (HR)

- Removal takes place by:

- $\quad$ shedding (distinction between drop detachment and film movement) (SH)

- erosion by impacting particles (ER)

- sootblowing (SB).

The build-up of a deposit can thus be expressed as a function of time:

$\frac{d m}{d t}=I P+C O+T H+B D+E D+H R-S H-E R-S B$

where the mechanisms are a function of time (starting when the heat exchanging surface is clean) and clock time $\tau$ related to human influences such as sootblowing.

\subsubsection{Inertial impaction}

Inertial impaction is an important phenomenon in deposit build up, Baxter and DeSollar (1993) report it to be often the bulk of mass of ash deposition [79]. A particle, following the streamlines of the gas, can with a changing streamline due to its inertia no longer follow the streamline and impact on a heat changing surface, see Figure 2.14. A particle can stick to the surface (deposit) after impaction, or rebound and re-entrain into the flow and/or erode the deposit. 

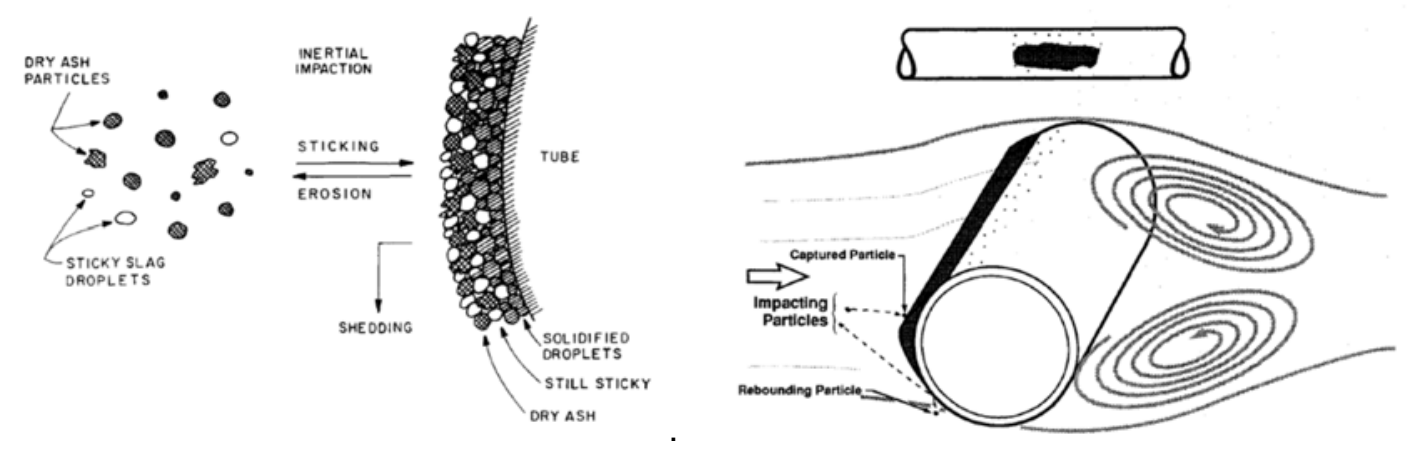

Figure 2.14 Inertial impaction. Source (left): [80]. Source (right): [30].

The deposition rate by inertial impaction of larger particles is determined by the mass flow of particles, the chance of impacting and the probability of sticking and can be described by:

$I=u_{f} \cdot C_{a s h, 1} \cdot \eta_{I} \cdot f_{\text {stick }} \cdot s$

with $u_{f}$ the bulk gas velocity, $C_{a s h, 1}$ the mass concentration of fly ash particles, $\eta_{I}$ the total impaction efficiency, $f_{\text {stick }}$ the total sticking coefficient, and $s$ the surface area at angle section theta. The impaction efficiency and the sticking probability are discussed in the following.

Impaction efficiency for a tube perpendicular to the flow Inertial impaction depends on the inertial momentum of the particle, the drag force exerted on the particle and the position of the particle relative to the central line of the flow pattern. Inertial impaction depends on the relaxation (or stopping) time $\tau$ of a particle which is the time for a particle to settle to the new balance of forces. It is defined as

$\tau=m v / F_{d}$

which is the ratio of momentum and drag force. For a spherical particle in a viscous fluid, Stokes' law holds for small Reynolds numbers (e.g. with very small particles)

$F_{d}=3 \pi \mu d_{p} v$

with $\mu$ the dynamic viscosity of the gas and $d_{p}$ the diameter of the particle. Inertial impaction occurs when the distance a particle travels before it fully adjusts to changes in the fluid velocity is larger than the length scale of an object, or target, submerged in the fluid. The particle Stokes number Stk is defined as the ratio of these length scales: 
$S t k=\frac{\tau \bar{u}}{d_{c} / 2}=\frac{\rho_{d} d_{p}^{2} \bar{u}}{9 \mu d_{c}}$

Hence, a correlation can be made between impaction efficiency and Stokes number. This was calculated by Brun et al. (1955) [81] and recalculated by Wessel and Righi (1988) [82] by calculating the trajectories of the particles, see Figure 2.15. The efficiency is defined as the fraction of particles passing through the projected area of the cylinder that actually hit the cylinder.

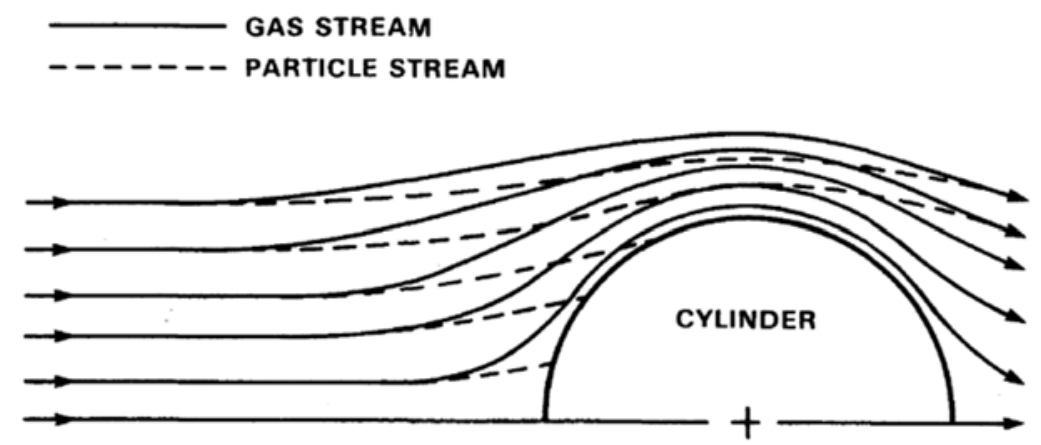

Figure 2.15 Trajectories of particles in gas flow around cylinder; source: [82].

Typically curves are made for different flow characteristics, i.e. for different numbers of $\phi=\mathrm{Re}^{2} /$ Stk with $\mathrm{Re}$ the Reynolds number of the gas flow. However, Israel and Rosner (1983) showed that the efficiency could be written in terms of the effective Stokes number alone [83]. This takes account non-Stokesian drag a by a correction function:

$S t k_{e f f}=S t k \cdot \Psi(\mathrm{Re})$

with the correction function for non-Stokesian drag as:

$\Psi(\operatorname{Re})=\frac{3\left(\sqrt{c} \mathrm{Re}_{p}^{1 / 3}-\tan ^{-1}\left(\sqrt{c} \mathrm{Re}_{p}^{1 / 3}\right)\right)}{c^{3 / 2} \operatorname{Re}_{p}}$

For engineering purposes (to avoid lengthy calculations of trajectories) a curve fit was made for the impaction efficiency by [82]:

$\eta\left(\mathrm{Stk}_{\mathrm{eff}}\right)\left\{\begin{array}{c}b \ln 8 \mathrm{Stk}_{\mathrm{eff}}+c\left(\mathrm{Stk}_{\mathrm{eff}}-a\right)+d\left(\mathrm{Stk}_{\mathrm{eff}}-a\right)^{2}, 0.125<\mathrm{Stk}_{\mathrm{eff}} \leq 0.5 \\ {\left[1+a\left(\mathrm{Stk}_{\mathrm{eff}}-a\right)^{-1}+b\left(\mathrm{Stk}_{\mathrm{eff}}-a\right)^{-2}+c\left(\mathrm{Stk}_{\mathrm{eff}}-a\right)^{-3}\right]^{-1}, \mathrm{Stk}_{\mathrm{eff}}>0.5}\end{array}\right.$ 
with $a=0.125$ and $b, c$ and $d$ dependent on the effective Stokes number as given in Table 2.3. Calculation results are shown in Figure 2.16.

Table 2.3 Curve fitting constants in impaction efficiency equation

\begin{tabular}{lccc}
\hline & $b$ & $c$ & $d$ \\
\hline $0.125<S t k_{\text {eff }} \leq 0.5$ & 0.01978749 & 0.5136545 & -0.0482858 \\
\hline$S t k_{\text {eff }}>0.5$ & 1.54424 & -0.538013 & 0.2020116 \\
\hline
\end{tabular}

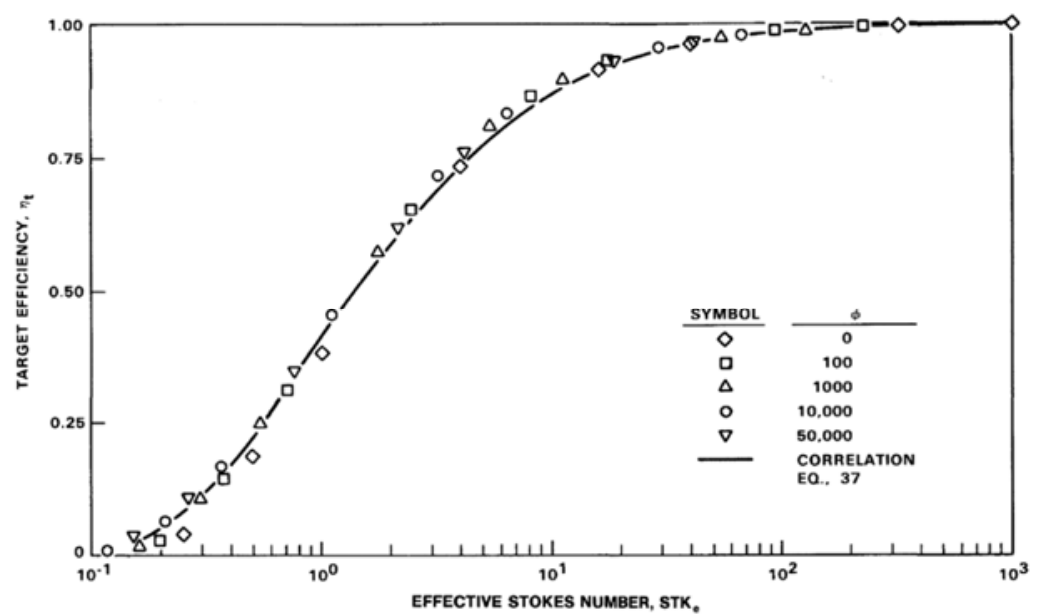

Figure 2.16 Impaction efficiency as function of the effective Stokes number; source: [82].

\section{Sticking probability}

Sticking probability largely depends on the contact area between a particle and the surface upon which a particle is to stick. The physical process of sticking can be approached from different perspectives. Walsh et al. (1990) sketch the following approaches related to ash deposition [80], based on:

- the solid character of particles,

- solid particles with a thin coating with a low viscosity and

- (supercooled) liquid particles. 
The approach based on the solid character of particles is that the probability of sticking is increased with increasing contact surface area which increases with elastic-plastic deformation of the particles and deposit surface with collision. For solid particles this is related to the velocity of the impacting particle. Reference is made to [84].

Wibberly and Wall (1982) explain sticking of silica particles by formation of a layer of $\mathrm{NaCl}$ with low viscosity on the particle surface [49]. The thickness of the layer determines the contact area during impaction. Walsh et al. (1990) relate the sticking probability to the viscous flow of (supercooled) liquid slag droplets [80]. The approach is justified by reasoning that most particles are at least partly fused in the flame. The deformation of a particle during impaction increases the surface area. This deformation of a liquid droplet is determined by its viscosity and hence the sticking probability was calculated by Walsh et al. (1990) [80] as:

$p_{\text {stick }}= \begin{cases}\frac{\mu_{r e f}}{\mu}, & \mu>\mu_{r e f} \\ 1, & \mu \leq \mu_{r e f}\end{cases}$

Alternatively, the sticking probability can be related to the critical viscosity rather than the reference viscosity:

$p_{\text {stick }}= \begin{cases}0, & \mu>\mu_{\text {crit }} \\ 1, & \mu \leq \mu_{\text {crit }}\end{cases}$

Various models are available for coal slag viscosity. An advantage of this method is that viscosity depends on temperature and composition and as such sticking probability can be formulated in those terms. The viscosity strongly depends on the temperature and considering the temperature range during combustion (applying any of the available viscosity models), a viscosity of a slag particle can easily vary between 1 and $1 \cdot 10^{8} \mathrm{~Pa} \cdot \mathrm{s}$. The difference in results when applying equations 2.14 or 2.15 is only small and is in the area just above the critical / reference viscosity. However, values found in literature for $\mu_{\text {ref }}$ and $\mu_{\text {crit }}$ (applied to coal firing) are unexpectedly large. Where values for $\mu_{\text {ref }}$ lie between 2 and $25 \mathrm{~Pa} \cdot \mathrm{s}$, see $[85,80,86]$, the values for $\mu_{\text {crit }}$ lie between $10^{5}$ and $10^{8} \mathrm{~Pa} \cdot \mathrm{s}$, see [87, 88, 89]. A value of $\mu_{\mathrm{ref}}=8 \mathrm{~Pa} \cdot \mathrm{s}$ is given by Walsh et al. (1990) [80]; however, this applies to the bulk ash composition whereas a viscosity based on molten slag particles only is a more logical approach. In addition, different models predict viscosity with differences of several orders of magnitude. Vargas (2001) states that for different coal/biomass blends the different viscosity models should be evaluated individually [90].

For iron-rich particles a sticking probability of temperature alone was given by Walsh et al. [80]. 
At an impaction event, of which the efficiency is described in the foregoing, a particle can stick to the surface when the particle is sticky enough. The sticking probability of a particle of a certain composition is $p_{\text {particle }}\left(T_{\text {gas }}\right)$ which depends on the particle temperature which is assumed to be equal to the (local) gas temperature [80]. Similar, the sticking probability of the deposit is $p_{\text {surf }}\left(T_{\text {gas }}\right)$. A cleaning effect due to erosion is determined by the erosivity of the dry ash $k_{e}$. The sticking coefficient $f_{\text {stick }}$ is described by Walsh et al. [80] as:

$$
f_{\text {stick }}=p_{\text {particle }}\left(T_{\text {gas }}\right)+p_{\text {surf }}\left(T_{\text {surf }}\right) \cdot\left\{1-p_{\text {particle }}\left(T_{\text {gas }}\right)\right\}-k_{e}\left\{1-p_{\text {particle }}\left(T_{\text {gas }}\right)\right\}\left\{1-p_{\text {surf }}\left(T_{\text {surf }}\right)\right\}
$$

Viscosity of silicate slags can be predicted on the basis of temperature and composition. Various models have been proposed in literature and are discussed in the following. Coal and biomass co-combustion ashes regularly contain high amounts of silica. Under atmospheric pressure, $\mathrm{Si}^{4+}$ assumes tetrahedral coordination, surrounded by $4 \mathrm{O}^{2-}$ anions [91], see Figure 2.17 (left). In pure crystalline solid $\mathrm{SiO}_{2}$, the structural $\mathrm{SiO}_{4}{ }^{4-}$ units are organized periodically, see Figure 2.17 (right, A). According to the random network theory of Zachariasen [91], the same basic structural units occur, but are connected in a random manner, see Figure 2.17 (right, B).
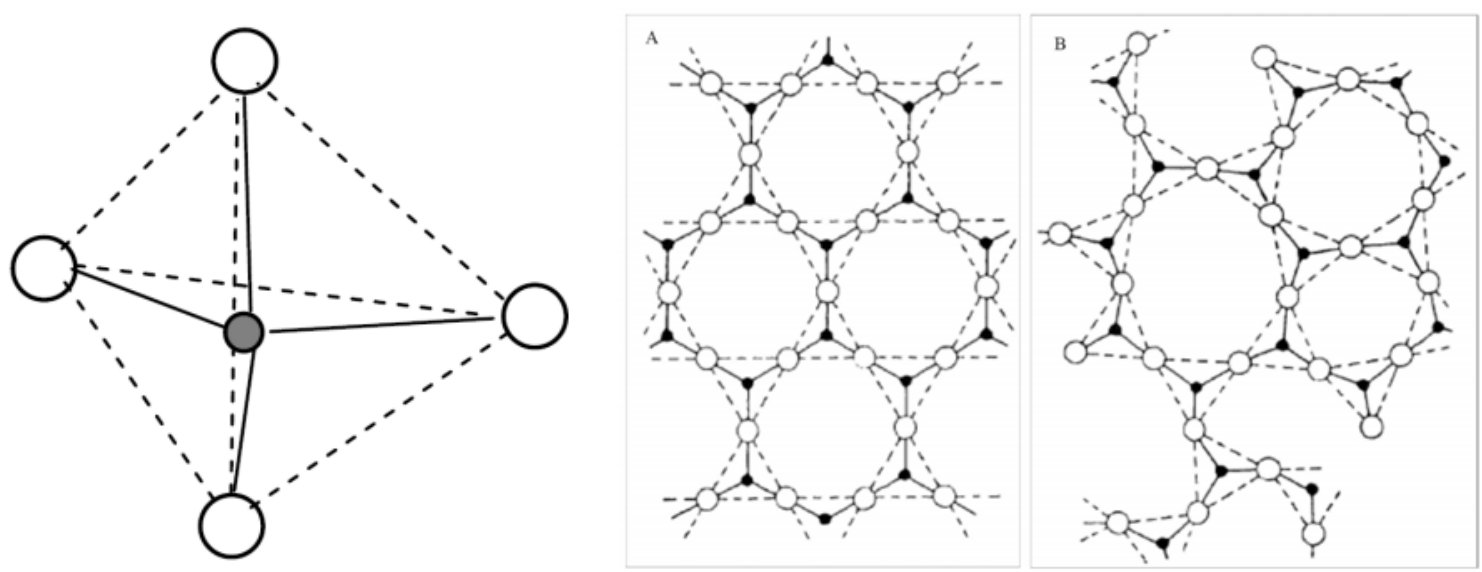

Figure 2.17 Left: Tetrahedrally coordinated silicate anion. Right: 2D representation of periodic arrangement in pure crystalline solid $\mathrm{SiO}_{2}(\mathrm{~A})$ and randomly connected $\mathrm{SiO}_{4}{ }^{4-}$ units in pure $\mathrm{SiO}_{2}$ liquid (B); source: [92].

Zachariasen suggested that glass formation is more likely with open, low density polyhedral structures and formulated following rules that oxides (of formula $A_{m} O_{n}$ ) generally have to obey for glass formation to occur [91]:

1) Oxygen atom may be linked to no more than two $A$ atoms;

2) The number of oxygen atoms surrounding $A$ atoms must be small ( 3 or 4); 
3) The oxygen polyhedra share only corners with each other, not edges or faces;

4) At least three corners in each polyhedron must be shared.

Oxides that obey these rules are referred to as network formers and include e.g. $\mathrm{SiO}_{2}$ and $\mathrm{P}_{2} \mathrm{O}_{5}$. Other oxides, like $\mathrm{Al}_{2} \mathrm{O}_{3}, \mathrm{CaO}, \mathrm{MgO}, \mathrm{K}_{2} \mathrm{O}, \mathrm{Na}_{2} \mathrm{O}$ don't and can't form glasses. However, they can occur in a (silicate) glass. Their behaviour is explained in the following.

There can be only three types of oxygen in a silicate melt, notably a) bridging oxygen, bonded to two silicon atoms, b) non-bridging oxygen, bonded to one silicon atom and associated to one metal atom and c) free oxygen, non bonded to silicon and associated to metal atoms only, see Figure 2.18.

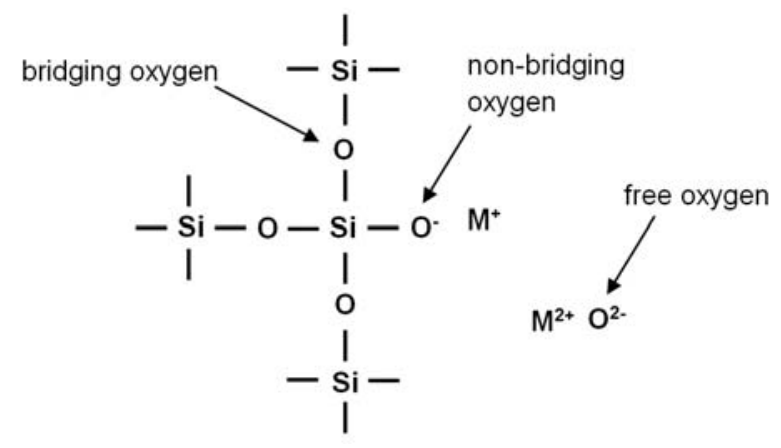

Figure 2.18 Types of oxygen in silicate melt.

In case a free oxygen ion is introduced in the melt, a silica-oxygen bridge is broken, resulting in two non-bridging oxygen ions, see Figure 2.19 (left). This means that a network connection between two structural $\mathrm{SiO}_{4}^{4-}$ units breaks down which influences (i.e. lowers) viscosity. If the introduction of a metal oxide into the silicate melt results in aforementioned phenomenon, the metal oxide is referred to as a network modifier; typical examples are alkali and alkali earth. In the presence of network forming oxides, the modifier oxides dissociate into cations and oxygen ions, because the attraction force between their cation and oxygen is weak in comparison to that of network forming oxides. 

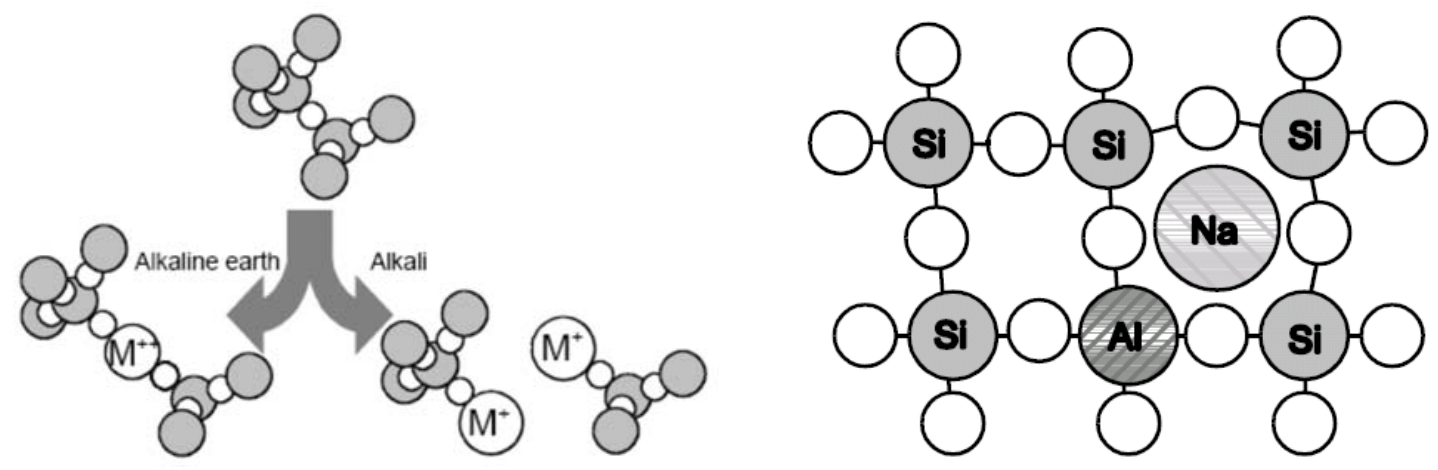

Figure 2.19 Left: weakening of silicate slag by alkaline earth and alkali. Right: Al is an amphoteric and can act as network former; source: [90].

Amphoterics act either as network modifiers or formers, depending on their coordination number in the melt. In combination with modifier ions, they can fit in the silicate network, as their charge is balanced by the modifier ion. As such, they act as a network former. An example is shown in Figure 2.19 (right)): $\mathrm{Al}_{2} \mathrm{O}_{3}$ takes up tetrahedral position with charge balancing by $\mathrm{Na}^{+}$. If insufficient modifiers are present, the amphoteric acts as a network modifier.

If the slag is considered to be a Newtonian fluid (that is when the fluid obeys Newton's law of viscosity that the viscosity gradient is proportional to the shear force) use can be made of a variety of generic models describing viscosity. The Arrhenius relation for viscosity of molten slags and glasses is (see e.g. [93]):

$\eta=\eta_{0} e^{\frac{E_{\eta}}{R T}}$

with $\eta_{0}$ a constant dependent on composition, $E_{\eta}$ the activation energy for viscous flow (it may be thought of as an energy barrier that must be overcome by molecular clusters or chains of the liquid moving relative to one another; also dependent on composition), $R$ the ideal gas constant and $T$ the temperature. To fit the preceding equation with data over a larger (low temperature) data range, the Fulcher, or Tamman-Vogel-Fulcher (TVF) empirical relation can be used:

$\eta=\eta_{0} e^{\frac{E_{\eta}}{R\left(T-T_{0}\right)}}$

where $T_{0}$ is a data fitting parameter. Specifically for melts with $\mathrm{SiO}_{2}$ where non-Arrhenius behaviour is observed for lower temperatures this equation is extremely important [94]. A generic 
relation for the viscosity introducing a linear temperature dependency is the Weymann-Frenkel relation:

$$
\eta=\eta_{0} T e^{\frac{E_{\eta}}{R T}}
$$

For coal ashes, the models of Urbain and Riboud give good results and are discussed in the following.

The model of Urbain uses the three categories of formers, modifiers and amphoteres. This model is based on a study of over 60 different $\mathrm{SiO}_{2}-\mathrm{Al}_{2} \mathrm{O}_{3}-\mathrm{M}_{\mathrm{x}} \mathrm{O}(\mathrm{x}=1$ or 2$)$ mixtures, where $\mathrm{M}_{\mathrm{x}} \mathrm{O}$ are oxides. It was tested on a wide variety of multi-phase systems. The following subdivision in molar fractions (fraction of the slag) is made:

- glass-formers: $x_{g}=\mathrm{SiO}_{2}+\mathrm{P}_{2} \mathrm{O}_{5}$

- network modifiers:

$$
x_{m}=\mathrm{FeO}+\mathrm{CaO}+\mathrm{MgO}+\mathrm{Na}_{2} \mathrm{O}+\mathrm{K}_{2} \mathrm{O}+\mathrm{MnO}+\mathrm{NiO}+2\left(\mathrm{TiO}_{2}+\mathrm{ZrO}_{2}\right)+3 \mathrm{CaF}_{2}
$$

- amphoteres: $x_{a}=\mathrm{Al}_{2} \mathrm{O}_{3}+\mathrm{Fe}_{2} \mathrm{O}_{3}+\mathrm{B}_{2} \mathrm{O}_{3}$

It was argued by Mills (1986) that $\mathrm{Fe}_{2} \mathrm{O}_{3}$ behaves more like a modifier than an amphoteric and therefore should be moved to the network class as $+1.5 \mathrm{Fe}_{2} \mathrm{O}_{3}$ [95].

Parameter $\alpha$ is then calculated by:

$$
\alpha=\frac{x_{m}}{x_{g}+x_{a}}
$$

The parameter $b$ is then calculated with the $\mathrm{SiO}_{2}$-concentration and four second order polynomials:

$$
\begin{aligned}
& b_{0}=13.8+39.9355 \alpha-44.049 \alpha^{2} \\
& b_{1}=30.481-117.1505 \alpha+129.9978 \alpha^{2} \\
& b_{2}=-40.9429+234.0486 \alpha-300.04 \alpha^{2} \\
& b_{3}=60.7619-153.927 \alpha+211.1616 \alpha^{2} \\
& b=b_{0}+b_{1} \cdot \mathrm{SiO}_{2}+b_{2} \cdot \mathrm{SiO}_{2}{ }^{2}+b_{3} \mathrm{SiO}_{2}^{3}
\end{aligned}
$$

With this, parameter $a$ is calculated: 
$-\ln a=c \cdot b+d$

where $c$ and $d$ are constants dependent on the type of the slag:

- ionic melts $\quad c=0.29$ and $d=13.87$

- network liquids $c=0.207$ and $d=12.591$

- $\mathrm{SiO}_{2}-\mathrm{Al}_{2} \mathrm{O}_{3} \quad c=0.247$ and $d=14.33$

- $\mathrm{SiO}_{2}-\mathrm{Be}_{2} \mathrm{O}_{3} \quad c=0.232$ and $d=10.987$

- $\mathrm{SiO}_{2}-\mathrm{PbO} \quad c=0.414$ and $d=14.425$

Network liquids are liquids like $\mathrm{SiO}_{2}$ and $\mathrm{B}_{2} \mathrm{O}_{3}$ and $\mathrm{GeO}_{2}$. Finally, the viscosity can be obtained from:

$\eta=a T e^{\frac{b \cdot 10^{3}}{T}}$

Temperatures are restricted to $T \geq T_{m}$ or $T_{l}$ for stable liquids, and $T>T_{g}$ for supercooled liquids, where are $T_{m}, T_{l}$ and $T_{g}$ are melting, liquidus and glass transition temperatures respectively.

The model of Riboud is based on experimental study of the $\mathrm{CaO}-\mathrm{Al}_{2} \mathrm{O}_{3}-\mathrm{SiO}_{2}-\mathrm{CaF}_{2}$ system for reevaluation of the Urbain model. The viscosity is calculated by Equation 2.20 where parameters $a$ and $b$ are determined by:

$\ln a=-35.76 \mathrm{Al}_{2} \mathrm{O}_{3}+1.73(\mathrm{FeO}+\mathrm{CaO}+\mathrm{MgO}+\mathrm{MnO})+7.02\left(\mathrm{Na}_{2} \mathrm{O}+\mathrm{K}_{2} \mathrm{O}\right)+5.82 \mathrm{CaF}_{2}-19.81$

$b=68.833 \mathrm{Al}_{2} \mathrm{O}_{3}-23.869(\mathrm{FeO}+\mathrm{CaO}+\mathrm{MgO}+\mathrm{MnO})-39.159\left(\mathrm{Na}_{2} \mathrm{O}+\mathrm{K}_{2} \mathrm{O}\right)-46.356 \mathrm{CaF}_{2}+31.140$

Here $\mathrm{Al}_{2} \mathrm{O}_{3}, \mathrm{FeO}$, et cetera, denote mole fractions of the slag.

For biomass co-firing, little is known for the applicability of viscosity models. Vargas (2001) concluded that for $25 \%$ of co-firing of wheat straw with coal, Urbain's model gave best results with an error margin of $20 \%$ [90].

Other approached to sticking are based on surface tension and contact angle with the substrate. However, these seem of minor importance and the majority of particle deposition is determined by the work of deformation against viscosity, rather than surface tension effects [96]. 


\subsubsection{Thermophoresis}

Particles that are gas borne are subjected to a force due to a local temperature gradient. The net force is called thermophoretic force $F_{T}$ and a simple explanation for it is that a gas borne particle is bombarded by hot and cold gas molecules by which the hot gas molecules have more kinetic energy resulting in a net force opposite to the temperature gradient, see Figure 2.20. A low temperature layer in the vicinity of a superheater tube may cause formation of submicron $\mathrm{KCl}$ and $\mathrm{K}_{2} \mathrm{SO}_{4}$ particles which migrate towards the surface by thermophoresis and deposit. With accumulating of deposit, the temperature gradient decreases and therefore the driving force of thermophoresis. Thermophoresis may contribute to deposition but other deposition mechanisms contribute to a larger mass fraction of the total deposition in (biomass) combustion [19]. Thermophoretic deposit is more finely grained and evenly distributed than deposits from impact.

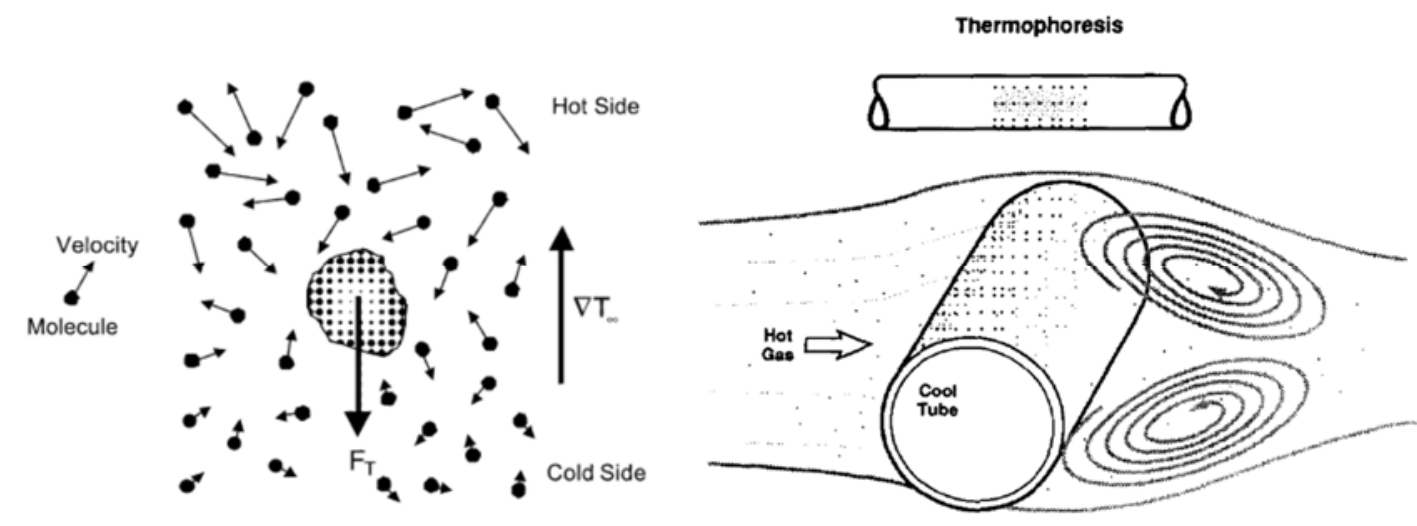

Figure 2.20 Thermophoresis. Gas borne particle with temperature gradient $\nabla T_{\infty}$ and thermophoretic force $F_{T}$ indicated; source: [97] (left). Thermophoretic deposition on a tube in cross-flow; source: [19] (right).

\subsubsection{Comparison of inertial and eddy impaction and thermophoresis}

In Figure 2.21 the relative importance is shown of the deposition mechanisms of thermophoresis, eddy impaction and inertial impaction related to particle size. These are outcomes of CFD results, see [98]. Here is shown that particularly the smaller particles deposit by thermophoresis. Its mass contribution is relatively small compared to inertial impaction, which is a deposit mechanism governing for larger particles. Eddy impaction is a mechanism which is less important, and mainly occurs with larger particles. 


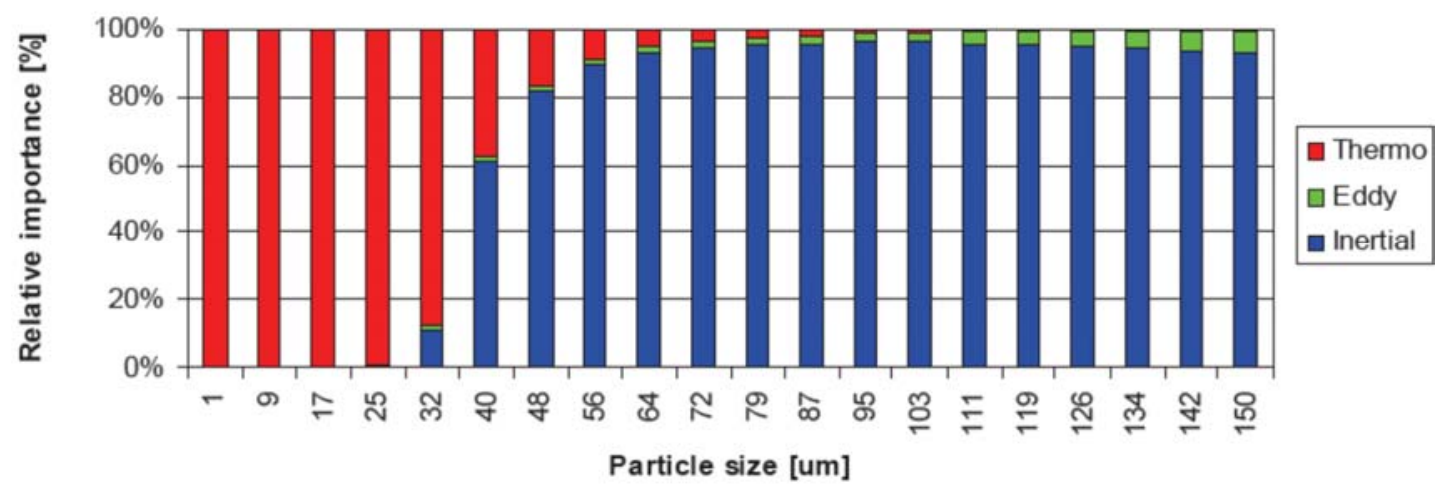

Figure 2.21 Relative importance of eddy and inertial impaction and thermophoresis; source: [98].

\subsubsection{Condensation}

Condensation has a minor contribution to deposition when firing high rank coals, but is more significant when firing low rank coals, biomass or lignite. Still, a modelling study [99] showed that with the combustion of lignite, the total accumulated mass (after $>1 \mathrm{hr}$ of deposition time) of condensation is $<1 / 10^{\text {th }}$ of the mass deposited by thermophoresis and $<1 / 100^{\text {th }}$ of the mass deposited by inertial impaction. However, its effect on removability (bulk strength), thermal conductivity, mass diffusivity is more significant, e.g. by increase contact area in the deposit. In deposition, condensation occurs when a vapour enters the thermal boundary layer around a cool surface.

Baxter (1993) describes that condensation occurs by (at least) three mechanisms: (1) heterogeneous condensation of vapours on the surface or within the deposit, (2) homogeneous condensation in the bulk gas and transport by thermophoresis, (3) heterogeneous condensation on particles in the boundary layer and transport by thermophoresis [30].

\subsubsection{Heterogeneous reaction}

Chemical reactions with the deposit can cause the deposit to accumulate mass [30]. With respect to deposition the most important reactions are:

- sulphation,

- alkali absorption and

- oxidation.

Sulphation concerns mainly the alkali metals which, if present as hydroxides or chlorides, can react and form sulphates. Alkalis can also react with silica to form lower melting silicates which 
induce sintering and significant changes in deposit properties. These reactions are slower than sulphation [30]. Unburnt carbon present in deposits (typically less than $2 \%$ ) can oxidize.

\subsubsection{Sintering}

Sintering is a process where particles are attached together during heating (but below the melting point). Driving force for this mechanism is the decrease of free surface energy which decreases with increase of particle-particle interfaces at the expense of particle-gas interfaces. The number of contact points between particles increases (see Figure 2.22) and hence a dense and hard material is produced.
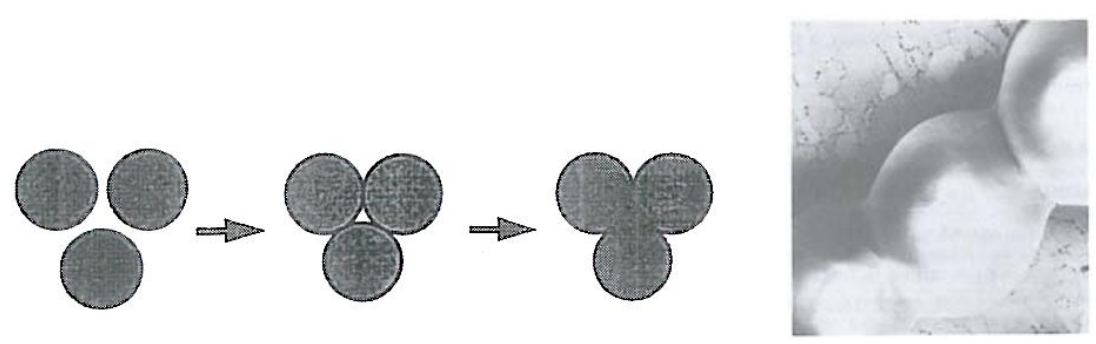

Figure 2.22 Sintering of particles (left); source: [23]. Sintered ash under laboratory conditions; source: [9].

Several mechanisms of sintering have been identified and are summarized by Zboger et al. (2009): evaporation-condensation sintering, liquid state sintering, viscous flow sintering, sintering with a reactive liquid, chemical reaction sintering and solid state sintering [100].

\section{Evaporation-condensation sintering}

At a curved surface with a positive radius of curvature is a higher vapour pressure (evaporation) than at a flat or even negatively curved surface (as in the "neck" at the interface of two particles). This is due to the higher surface energy. The result is a net mass transport by evaporation and condensation is featured in Figure 2.23. 


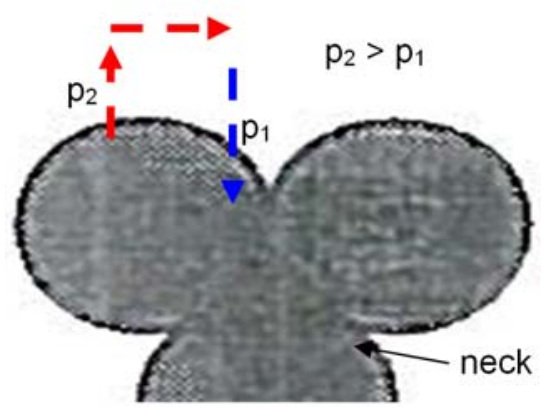

Figure 2.23 Principle of evaporation-condensation sintering.

Liquid state sintering, viscous flow sintering and sintering with reactive liquid

At the sintering temperature liquid melts can be present (due to the inhomogeneous composition) which flow and cause "neck" formation. Driving force for the flow is the capillary pressure in the liquid phase located between the fine solid particles. The controlling parameter is the amount of liquid formed. When in this liquids highly viscous melts (silicate slags) are involved, this is called viscous flow sintering. Controlling parameters are time and melt viscosity. Sintering with a reactive liquid occurs when the solid material is (to a certain extent) soluble in the melt.

\section{Chemical reaction sintering}

Chemical reaction can occur between particles or particles and the gas phase. A third phase can be produced. An example is sulphation of the deposit causing neck formation or formation of a melt.

\section{Solid state sintering}

Solid state sintering occurs as a result of difference in free energy or chemical potential between neck area and the particle surface and hence mass transfer may occur by vapour transport or by surface-, lattice-, or grain boundary diffusion from the particle surface, the particle bulk, or the grain boundary between particles [100]. Although it is a slow process - much slower than e.g. liquid state sintering where a melt is involved - it may play a role in densification of low temperature deposits.

Sintering can influence the build-up and strength of the deposits. Hereby it must be marked that in relation to removing ashes by sootblowing (i.e. a continuous boiler operation) deposit strength is of more importance than the rate of deposit build-up [101]. The strength development can also occur by solidification, which is dominant in the high temperature regions such as at the superheaters, whereas sintering is dominant at the lower temperature region such as the economizer inlet [102]. 


\subsubsection{Natural shedding}

Zbogat et al. (2009) have reviewed the current status on shedding of deposits [100]. Where deposit formation has been studied rather extensive, the study of deposit shedding is relatively limited. Discrimination is made between natural removal and artificial removal of deposits, the latter by soot blowing which is treated in the next paragraph. An overview of shedding mechanisms is shown in Figure 2.24.

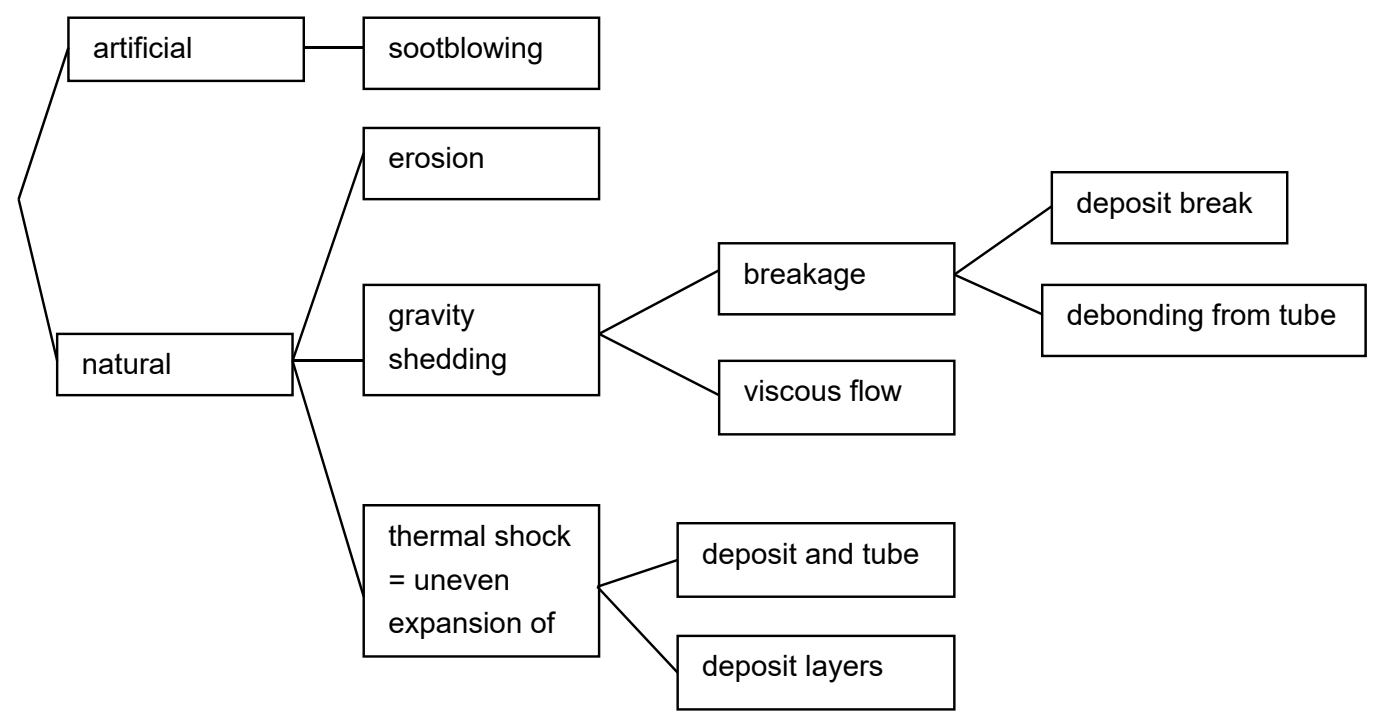

Figure 2.24 Classification of removal (shedding) of deposits, based on [100].

In 
Table 2.4 the removal mechanisms are related to the position in the deposit and the deposit type. 
Table 2.4 Removal mechanisms related to position in the deposit and deposit type; modified from [100].

\begin{tabular}{|c|c|c|c|c|c|c|c|}
\hline \multirow{2}{*}{$\begin{array}{l}\text { Removal } \\
\text { mechanism }\end{array}$} & \multicolumn{3}{|c|}{ Position of deposit removal } & \multicolumn{4}{|c|}{ Deposit type } \\
\hline & $\begin{array}{l}\text { Tube- } \\
\text { deposit } \\
\text { interface }\end{array}$ & $\begin{array}{l}\text { Within the } \\
\text { deposit }\end{array}$ & $\begin{array}{l}\text { Deposit } \\
\text { surface }\end{array}$ & Powdery & $\begin{array}{l}\text { Lightly } \\
\text { sintered }\end{array}$ & $\begin{array}{l}\text { Heavily } \\
\text { sintered }\end{array}$ & Liquid slag \\
\hline erosion & & & + & ++ & + & - & - \\
\hline $\begin{array}{l}\text { gravity } \\
\text { shedding }\end{array}$ & + & + & & ++ & + & - & - \\
\hline $\begin{array}{l}\text { melting } \\
\text { (liquid flow) }\end{array}$ & & & + & - & - & - & ++ \\
\hline $\begin{array}{l}\text { thermal } \\
\text { shock }\end{array}$ & + & + & & - & + & ++ & - \\
\hline $\begin{array}{l}\text { mechanical } \\
\text { shock }\end{array}$ & + & + & & ++ & ++ & + & - \\
\hline
\end{tabular}

Deposits can be ductile or brittle. Transition of a brittle to ductile character is dependent on temperature and composition. Piroozmand et al. (1998) investigated this behaviour by using precipitator dusts and concluded that the brittle-to-ductile transition occurs at $700{ }^{\circ} \mathrm{C}$ for deposits without chlorine and at $500-550^{\circ} \mathrm{C}$ for deposits with chlorine [102].

\subsubsection{Erosion}

Erosion is caused by collision of hard particles (mainly quartz) with deposits. The incoming particles can cause deformation (prominent for brittle deposits) and cutting (main wear of ductile deposits). Water droplets from sootblowing by steam can also cause erosion. Erosion takes place mainly at the superheater, reheater and economizer area [103].

Deposit characteristics very much influence the erosion behaviour. A deposit with higher porosity will be susceptible to a higher erosive wear. Also hardness plays an important role: Raask (1985) found that erosion wear resistant material should have a hardness of about $500 \mathrm{~kg} / \mathrm{mm}^{2}$ higher than the impacting particles, while silica has a hardness of about $1,100 \mathrm{~kg} / \mathrm{mm}^{2}$ [9]. When hardness of impacting particles and deposit are equal, erosion is significantly lower than when incoming particles are harder. Maximum erosion of ductile deposits occurs at an angle of impact (angle between deposit and trajectory of incoming particle) of $15-30^{\circ}$ whereas brittle deposits are eroded at maximum with an impacting angle of $90^{\circ}$. Spherical particles (i.e. glass) cause deformation leading to wear of brittle deposits. Angular quartz particles at the other hand cause erosion by cutting. Small particles $(<5 \mu \mathrm{m})$ have a small inertial momentum and erosion rate is insignificant. Up to $45 \mu \mathrm{m}$ the erosion rate increases and stays constant thereafter. Velocity of 
the particles also contributes to the erosion rate. Modelling is described in [100]. Results as function of material hardness, impacting angle and particle properties are shown in Figure 2.25.

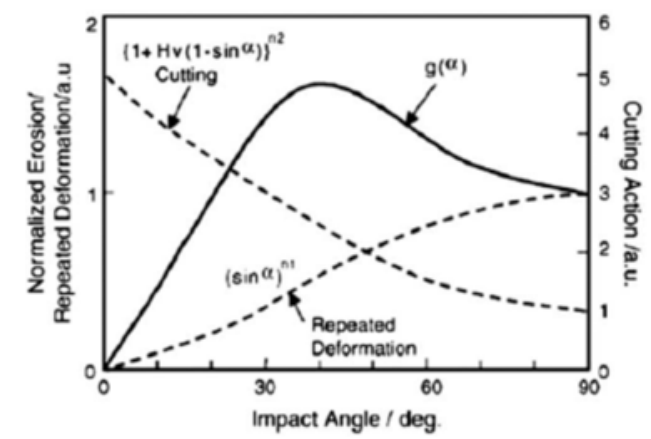

Figure 2.25 Modelling results of erosion caused by deformation and cutting actions; source: [104].

\subsubsection{Gravity shedding and viscous flow}

When the forces of gravity and adhesion become unbalanced, a deposit will fall of. Adhesion forces are those (1) between deposit and (tube) surface and (2) bond strength within the deposit, see Figure 2.26 (left). This is also referred to as detachment (1) and break-up of weak deposits (2).

Matured deposits will have a temperature gradient from the tube surface up to the flue gas temperature. At such high temperatures as of the flue gas, deposits can melt and flow. An equilibrium situation should be reached where the mass flow of running slag balances the mass flow of incoming depositing particles [100]. It has been shown that in biomass fired boilers viscous flow is an important shedding mechanism [105].

\subsubsection{Thermal shock}

Thermal shock is a consequence of unequal thermal expansion of deposit and tube or different layers of a deposit. Difference in expansion depends on the difference in thermal expansion coefficient $\alpha[\mathrm{m} / \mathrm{mK}]$ and the temperature difference applied, e.g. by sudden cooling. The resulting thermal stresses can cause the deposit to crack, see Figure 2.26 (right). 

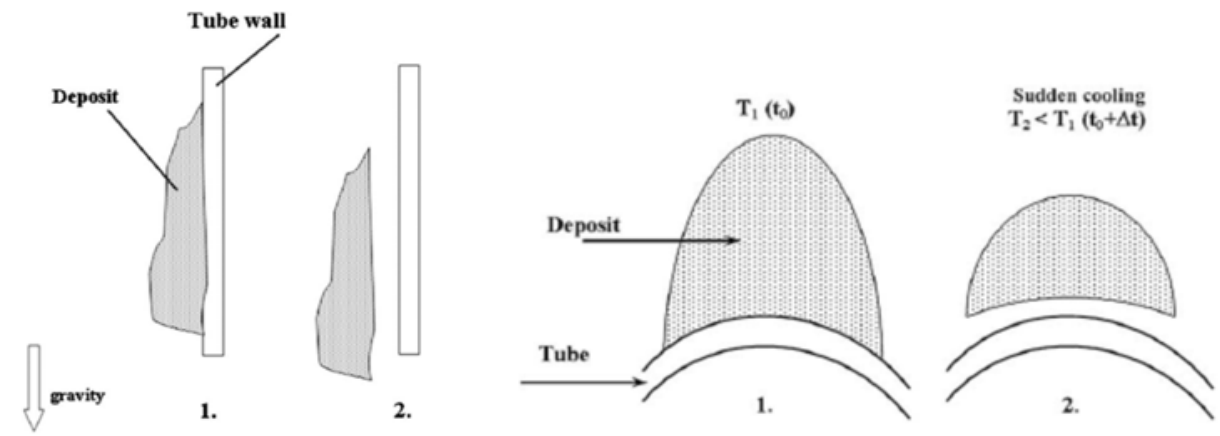

Figure 2.26 Left: gravity shedding. Right: thermal shock. Source: [106].

In reference [9] it is stated that between deposits and mild-steel there is not much difference in thermal expansion and removal by thermal shock is not easy. This is different with austenitic steels which have a thermal expansion coefficient which is significantly higher than of deposits. The thin oxide layer has a lower expansion coefficient. An observed effect with austenitic steels is that oxide layer is peeled of during cooling with deposits. This is not observed with clean austenitic tubes or ferritic tubes.

\subsubsection{Soot blowing}

The term soot blowing is related by history to the removal of soot deposits in railway locomotive engines and small boilers [9]. Only little soot and merely ashes deposit in pulverized coal fired boilers so the term "soot blowing" is somewhat misleading. Soot blowers for wall cleaning protrude the boiler wall and steam is blown on the wall; a circular wall area is covered as the blower revolves, see Figure 2.24 (left). Soot blowers for cleaning bundles operate in a similar way, but are normally able to protrude further, see Figure 2.27 (right).
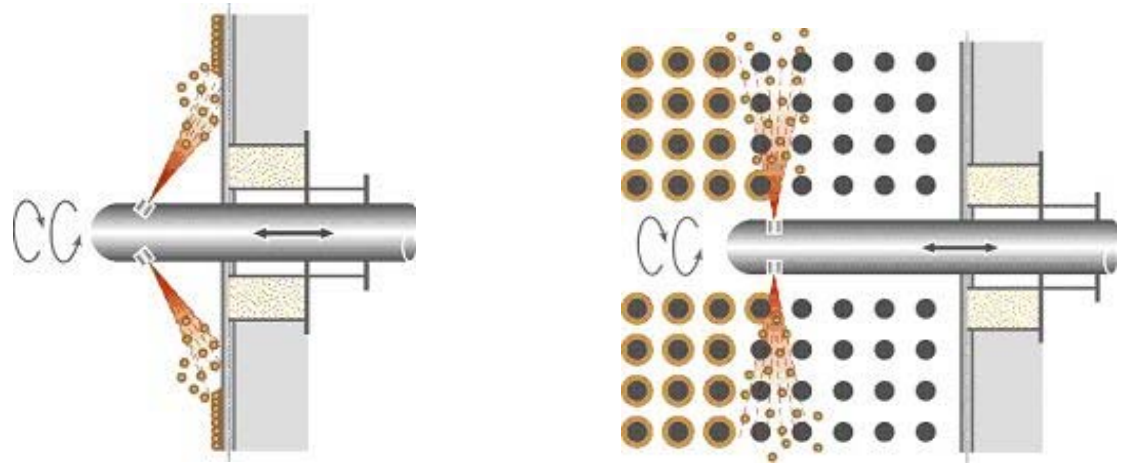

Figure 2.27 Soot blowing at boiler water walls (left) and in the convective pass (right); source: [107]. 
Within one nozzle diameter an expanding jet mixes with approximately an equal volume of the ambient gas; by the time the expanding jet hits the surface (length is $40-100$ times the nozzle diameter) the cleaning medium is largely flue gas [9]. As a blowing medium, saturated or overheated steam is normally used while air can be used as well. Another medium that can be used is water with which a high momentum can be generated. In addition, droplets can quickly evaporate as they hit the deposit and mechanically fracture the deposit upon rapid volumetric expansion. Its application is in more slagging circumstances such as firing with lignite. A disadvantage of blowing with water instead of steam is the problem of erosion caused by the water droplets (which can also occur when starting with blowing using steam as the blower contains condensed water). Another problem is thermal shock which is instant cooling of the surface by the water that may lead to thermal fatigue cracking. 


\section{References}

[1] Bryers RW. Fireside slagging, fouling and high-temperature corrosion of heat transfer surface due to impurities in steam-raising fuels. Prog Energ Combust, 1996, 22, 29 - 120.

[2] Couch G. Understanding slagging and fouling during pf combustion. IEA Coal Research, No. IEZCR/72, 1994.

[3] Wall TF. Mineral matter transformations and ash deposition in pulverised coal combustion; Twenty-Fourth symposium (international) on combustion/The combustion Insitute, pp. 11191126, 1992.

[4] Benson SA, Jones ML, Harb JN. Ash formation and deposition. In: Fundamentals of coal combustion - for clean and efficient use (Ed. Smoot, L.D.), Coal Science and Technology 20, pp. 299 - 373, ISBN 0444896430, Amsterdam, 1993.

[5] Ward CR. Analysis and significance of mineral matter in coal seams. Int J Coal Geol, 2002, $50,135-68$.

[6] Finkelman RB. Modes of occurrence of trace elements in coal. U.S. Geological Survey, open file report 81-99, 1981.

[7] Renton JJ. Semiquantitative determination of coal minerals, In: Mineral matter and ash in coal, pp. 53 - 60 (Ed. K.S. Vorres) ISBN 0841209596, 1986.

[8] CRC Handbook of Chemistry and Physics. 73rd ed. Lide, D.R. Ed.; CRC Press: Boca Raton, FL, 1992, Section 4, pp 36-114.

[9] Raask E. Mineral impurities in coal combustion, Behavior, problems and remedial measures. ISBN 089116362X, Hemisphere, New York, 1985.

[10] Calkins WH. The chemical forms of sulfur in coal: a review. Fuel, 1994, 73, $475-84$.

[11] Gluskoter HJ, Shimp NF, Ruch RR. Coal analyses, trace elements, and mineral matter. In: Chemistry of coal utilization (Ed. Elliott, M.A.), ISBN 0471077267, 1981.

[12] Kinoshita K, Tsuneo H, Nobuya T. Kyoshu Kozon Gakkai-shi, 1966, 34, 377 - 80 (as referred in [11]). 
[13] Vassilev SV, Eskenazy GM, Vassileva CG. Contents, modes of occurrence and origin of chlorine and bromine in coal. Fuel, 2000, 79, $903-21$.

[14] Triplehorn D, Bohor B. Volcanic ash layers in coal: origin, distribution, composition and significance. In: Mineral matter and ash in coal, pp. 90 - 99 (Ed. K.S. Vorres) ISBN 0841209596, 1986.

[15] Swaine DJ. The organic association of elements in coals. Org Geochem, 1992, 18, 259 - 61.

[16] Finkelman RB, Palmer CA, Wang P. Quantification of the models of occurrence of 42 elements in coal. Int Coal Geol, 2018, 185, 138-60.

[17] Zevenhoven-Onderwater M. Ash-Forming Matter in Biomass Fuels, Academic Dissertation, Åbo Akademi University, 2001.

[18] Doshi V. Investigation into ash related issues during co-combustion of coal and biomass: development of a co-firing advisory tool. PhD Thesis. Curtin University of Technology, 2007.

[19] Baxter LL, Miles TR sr, Miles TR jr, Jenkins BM, Milne T, Dayton D, Bryers R, Oden LL. Alkali deposits found in biomass boilers. The behavior of inorganic material in biomass-fired power boilers: field and laboratory experiences. Report NREL/TP-433-8142, SAND96-8225, 1996.

[20] Van Ryssen JBJ, Ndlovu H. Review: Wood ash in livestock nutrition: 1. Factors affecting the mineral composition of wood ash. $A A H \& R D, 2018,11,53-61$.

[21] Dzurenda L, Pňakovič L. Analysis of the inorganic matter in wood and bark proceedings for the energetic woodchips of the plantation grown tree species Robinia Pseudoacacia via the AESICP. Key Eng Mat, 2016, 688, 218-25.

[22] Tortosa Masiá AA, Buhre BJP, Gupta RP, Wall TF. Characterising ash of biomass and waste. Fuel Process Technol, 2007, 88, 1070 - 81.

[23] Andersen $\mathrm{KH}$. Deposit formation during coal-straw co-combustion in a utility pf-boiler, PhD Thesis, Technical University of Denmark, 1998.

[24] Knudsen JN, Jensen PA, Dam-Johansen K. Transformation and release to the gas phase of $\mathrm{Cl}, \mathrm{K}$ and S during combustion of annual biomass. Energ Fuel, 2004, 18, 1385 - 99.

[25] Mlonka-Mędrala A, Magdziarz A, Gajek M, Nowińska K, Nowak W. Alkali metals association in biomass and their impact on ash melting behaviour. Fuel, 2020, 261. 
[26] Kubica R. Emission of pollutants from biomass combustion. In: Biomass in small-scale energy applications. (Ed: M. Szubel and M. Filipowicz). ISBN 9780429286063, 2019.

[27] Deydier, E, Guilet, R, Sarda, S, Sharrock, P. Physical and chemical characterisation of crude meat and bone meal combustion residue: "waste or raw material?" J Hazard Mater, 2005, 121, $141-8$.

[28] Heikkinen J. Characterisation of supplementary fuels for co-combustion with pulverised coal. PhD thesis, TUDelft, 2005.

[29] Yan L, Gupta RP, Wall TF. A mathematical model of ash formation during pulverized coal combustion. Fuel, 2002, 81, 337 - 344.

[30] Baxter LL. Ash deposition during biomass and coal combustion: a mechanistic approach. Biomass Bioenerg, 1993, 4, 85 - 102.

[31] Hurley JP, Schobert HH. Ash formation during pulverized subbituminous coal combustion. 1. Characterization of coals, and inorganic transformations during early stages of burnout. Energ Fuel, 1992, 6, $47-58$.

[32] Hurley JP, Schobert HH. Ash formation during pulverized subbituminous coal combustion. 2. Inorganic transformations during middle and late stages of burnout. Energ Fuel, 1993, 7, 542 53.

[33] Baxter L, Mehta A, Chaney J. Fireside coal quality impacts. In: Effects of coal quality on power plant management: Ash problems, management and solutions; March, 2001

[34] Stinespring CD, Zulkowski M, Mazza HH. Chemical transformations of the minerals in eastern bituminous coals under simulated pulverized coal firing conditions, Engineering Foundation Conference on "Ash deposits and Corrosion from Impurities in Combustion Gases", R.W. Bryers (ed.), 233 - 242, New England College, Henniker, New Hampsire, June 26, 1977.

[35] Mitchell PS, Gluskoter HJ. Mineralogy of ash of some American coals: variations with temperature and source. Fuel, 1976, 55, $90-6$.

[36] Huffman GP, Huggins FE. Reactions and transformations of coal mineral matter at elevated temperatures. In: Mineral matter and ash in coal, pp. $100-113$ (Ed. K.S. Vorres) ISBN $0841209596,1986$. 
[37] Kühnel RA, Eylands KE. Deviations of thermal transformation in open multicomponent systems: effects of mineralisers. In: Proceedings of the Engineering Foundation conference on inorganic transformations and ash deposition during combustion, Palm Coast, Florida, USA, 10 15 mar 1991. New York, NY, USA, American Society of Mechanical Engineers, pp. 449 - 458 , 1992.

[38] Steenari B-M, Lindqvist O. High temperature reactions of straw ash and the anti-sintering additives kaolin and dolomite. Biomass Bioenerg, 1998, 14, 67 - 76.

[39] Gupta SK, Gupta RP, Bryant GW, Wall TF. The effect of potassium on the fusibility of coal ashes with high silica and aluminium levels. Fuel, 1998, 77, $1195-1201$.

[40] Vassilev SV, Menendez R, Alvarez D, Diaz-Somoanob M, Martinez-Tarazonab MR. Phasemineral and chemical composition of coal fly ashes as a basis for their multicomponent utilization. 1. Characterization of feed coals and fly ashes. Fuel, 2003, 82, $1793-811$.

[41] Logan RG, Richards GA, Meyer CT, Anderson RJ. A Study of Techniques for Reducing ash deposition in coal-fired gas turbines. Prog Energ Combust, 1990, 16, 221 - 33.

[42] Spiro CL, Chen CC, Kimura SG, Lavigne G, Schields PW. Deposit remediation in coal-fired gas turbines through the use of additives. Prog Energ Combust, 1990, 16, 213 - 20.

[43] Glazer MP. Alkali metals in combustion of biomass with coal. PhD thesis, TU Delft, 2006.

[44] O'Gorman JV, Walker PL. Thermal behaviour of mineral fractions separated from selected American coals. Fuel, 1973, 52, $71-9$.

[45] Segnit FR, Anderson CA. Scanning electron microscopy of fired illite. Trans Brit Ceram Soc, 1972, 71, 85-8.

[46] Srinivasachar S, Helbe JJ, Boni AA, Shah N, Huffman GP, Huggins FE. Mineral behavior during coal combustion 2. Illite transformations. Prog Energ Combust, 1990, 16, 293 - 302.

[47] Schmuk ET. Thermodynamics of oxidation of pyrite in coal, Izv. Akad. Pp. 172 - 182, Nauk, USSR Ota Teckn Navie, Met, 1Toplivo 1960 as cited in [1].

[48] Srinivasachar S, Helbe JJ, Boni AA. Mineral behavior during coal combustion 1. Pyrite transformations. Prog Energ Combust, 1990, 16, 281 - 292. 
[49] Wibberley LJ, Wall TF. Alkali-ash reactions and deposit formation in pulverized-coal-fired boilers: the thermodynamic aspects involving silica, sodium, sulphur and chlorine. Fuel, 1982, 61, 87-92.

[50] Liu Y, Cheng L, Zhao Y, Jij J, Wang Q, Luo Z, Bai Y. Transformation behavior of alkali metals in high-alkali coals. Fuel Process Technol, 2018, 169, 288 - 94.

[51] Lindner ER, Manzoori AR, Wall TF. A theoretical analysis of sodium-silica reactions during pulverized coal combustion. In: Proceedings of the Engineering Foundation Conference on 'Inorganic Transformations and Ash Composition During Combustion', S. A. Benson (ed.), pp. 565-581, Sheraton Palm Coast, Florida, March,1991.

[52] Lindner ER, Wall TF. Sodium ash reactions during combustion of coal. Symposium on combustion, 1990.

[53] Helbe JJ, Srinivasachar S, Boni AA. Mechanisms of ash evolution - a fundamental study. Part 1: low rank coals and the role of calcium. In: Proceedings of the Engineering Foundation conference on inorganic transformations an ash deposition during combustion. Palm Coast, Florida, USA, 1991, New York, NY, USA, American Society of Mechanical Engineers, pp. 209 228, 1992.

[54] Seames WS. An initial study of the fine fragmentation fly ash particle mode generated during pulverized coal combustion. Fuel Process Technol, 2003, 81, 109 - 25.

[55] Linak WP, Miller A, Seames WS, Wendt JOL, Ishinomori T, Endo Y, Miyamae S. On trimodal particle size distributions in fly ash from pulverized-coal combustion. P Combust Inst, 2002, 29, $441-7$.

[56] Johanson J, Jakobsen JG, Frandsen FJ, Glarborg P. Release of K, Cl, and S during pyrolysis and combustion of high-chlorine biomass. Energ Fuels, 2011, 25, 4961 - 71.

[57] Knudsen JN. Volatilization of inorganic matter during combustion of annual biomass. PhD Thesis, Technical University of Denmark, 2004.

[58] Van Lith SC, Frandsen FJ, Montgomery MVT, Jensen SA. Lab-scale investigation of depositinduced chlorine corrosion of superheater materials under simulated biomass-firing conditions. Part 1: exposure at $560{ }^{\circ} \mathrm{C}$. Energy Fuels, 2009, 23, 3457 - 68.

[59] Davidsson KO, Stojkova BJ, Pettersson JBC. Alkali emission from birchwood particles during rapid pyrolysis. Energy Fuels, 2002, 16, 1033 - 9. 
[60] Knudsen JN, Jensen PA, Dam-Johansen K. Transformation and release to the gas phase of $\mathrm{Cl}, \mathrm{K}$, and S during combustion of annual biomass. Energy Fuels, 2004, 18, 1385 - 99.

[61] Knudsen JN, Jensen PA, Lin W, Frandsen FJ, Dam-Johansen K. Sulfur transformations during thermal conversion of herbaceous biomass. Energy Fuels, 2004, 18, 810 - 9.

[62] Kyi S, Chadwick BL. Screening of potential mineral additives for use as fouling preventatives in Victorian brown coal combustion. Fuel, 1999, 78, 845 - 55.

[63] Schümann H, Unterberger S, Hein KRG, Monkhouse PB, Gottwald U. The influence of fuel additives on the behaviour of gaseous alkali-metal compounds during pulverised coal combustion. Faraday Discuss, 2002, 119, 433 - 44.

[64] Zhen Z, Liu J, Shen F, Zhang Z, Dong Y. Release of Na from sawdust during air and oxy-fuel combustion: A combined temporal detection, thermodynamics and kinetic study. Fuel, 2018, 221 , $249-56$.

[65] Jensen PA, Frandsen FJ, Dam-Johansen K, Sander B. Experimental investigation of the transformation and release to gas phase of potassium and chlorine during straw pyrolysis. Energy Fuels, 2000, 14, 1280 - 5.

[66] Dare P, Gifford J, Hooper RJ, Clemens AH, Damiano LF, Gong D, Matheson TW. Combustion performance of biomass residue and purpose grown species. Biomass Bioenergy, $2001,21,277-87$.

[67] Björkman E, Strömberg G. Release of chlorine from biomass at pyrolysis and gasification conditions. Energy Fuels, 1997, 11, 1026 - 32.

[68] Van Lith SC, Jensen PA, Frandsen FJ, Glarborg P. Release to the Gas Phase of Inorganic Elements during Wood Combustion. Part 2: Influence of Fuel Composition. Energy Fuels, 2008, 22, $1598-1609$.

[69] Knudsen JN, Jensen PA, Lin W, Dam-Johansen K. Secondary capture of chlorine and sulfur during thermal conversion of biomass. Energy Fuels, 2005, 19, $606-17$.

[70] Van Lith SC, V. Alosno-Ramírez PAJ, Frandsen FJ, Glarborg P. Energy Fuels, 2006, 20, 964 -78 .

[71] Zevenhoven M, Blomquist J, Skrifvars B, Backman R, Hupa M. The prediction of behaviour of ashes from five different solid fuels in fluidised bed combustion. Fuel, 2000, 79, 1353 - 1361. 
[72] Jacobson, M.Z. Fundamentals of Atmospheric Modeling, ISBN 0521631432, Cambridge University Press, UK, 1999.

[73] Lyklema J. (ed.) Fundamentals of Interface and Colloid Science. Elsevier, 2005.

[74] http://en.wikipedia.org/wiki/Nucleation\#Heterogeneous nucleation. Visited January 2009.

[75] Pronobis M. Evaluation of the influence of biomass co-combustion on boiler furnace slagging by means of fusibility correlations. Biom Bioener, 2005, 28, $375-83$.

[76] Heinzl T, Siegle V, Spliethoff H, Hein KRG. Investigation of slagging in pulverized fuel cocombustion of biomass and coal at a pilot-scale test facility. Fuel Proc Tech, 1998, 54, 109 - 25.

[77] Smajevic I, Kazagic A, Music M, Becic K, Hasanbegovic I, Sokolovic S, Delihasanovic N, Skopljak A, Hodzic N. Co-firing Bosnian coals with woody biomass: experimental studies on a laboratory-scale furnace and $110 \mathrm{MWe}$ power unit. Therm Sci, 2012, 16, $789-804$.

[78] Skrifvars B-J, Laurén T, Hupa M, Korbee R, Ljung P. Ash behaviour in a pulverized wood fired boiler - a case study. Fuel, 2004, 83, 1371 - 9.

[79] Baxter LL, DeSollar RW. A mechanistic description of ash deposition during pulverized coal combustion: predictions compared with observations. Fuel, 1993, 72, $1411-8$.

[80] Walsh PM, Sayre AN, Loehden DO, Monroe LS, Beér JM, Sarofim AF. Deposition of bituminous coal ash on an isolated heat exchanger tube: effects of coal properties on deposit growth. Prog Energ Combust, 1990, 16, 327 - 345.

[81] Brun RJ, Lewis W, Perkins PJ, Serafini JS. Impingement of cloud droplets on a cylinder and procedure for measuring liquid-water content and droplet sizes in supercooled clouds by rotating multicylinder method. National Advisory Committee for Aeronautics (NACA) Report 1215, 1955.

[82] Wessel RA, Righi J. Generalized correlations for inertial impaction of particles on a circular cylinder. Aerosol Sci Tech, 1988, 9, 29 - 60.

[83] Israel R, Rosner DE. Use of a generalized Stokes number to determine the aerodynamic capture efficiency of non-Stokesian particles from a compressible gas flow. Aerosol Sci Tech, $1983,2,45-51$.

[84] Rogers DE, Reed J. The adhesion of particles undergoing a plastic-elastic impact with a surface. J Phys D Appl Phys, 1984, 17, 677 - 89. 
[85] Liebetruth M, Görner K, Hildebrandt V. Laufzeitkopplung von CFD und thermo-dynamischer Realphasenmodellierung zur Darstellung der Verschlackungsneigung. VDI Berichte, 2002, 1664, $41-52$.

[86] Beckmann AM, Mancini M, Weber R, Seebold S, Müller M. Measurements and CFD modeling of a pulverized coal flame with emphasis on ash deposition. Fuel, 2016, 167, 168 - 79.

[87] Wibberley LJ, Wall TF. Alkali-ash reactions and deposit formation in pulverized-coal-fired boilers: experimental aspects of sodium silicate formation and the formation of deposits. Fuel $1982,61,93-9$.

[88] Srinivasachar S, Senior CL, Helble JJ, Moore JW. A fundamental approach to the prediction of coal ash deposit formation in combustion systems. Twenty-Fourth Symposium (International) on Combustion/The Combustion Institute, 1992, 1179-87.

[89] Costen PG, Lockwood FC, Siddique MM. Mathematical modeling of ash deposition in pulverized fuel-fired combustors. Proc Combust Inst, 2000, 28, 2243 - 50.

[90] Vargas S. Straw and coal ash rheology. PhD Thesis, Technical University of Denmark, 2001.

[91] Zachariasen WH, The atomic arrangement in glass. J Am Chem Soc, 1932, 54, 3841 - 51.

[92] Richardson FD. Oxide slags - A survey of our present knowledge. In: The Physical Chemistry of Steelmaking, Proceedings of the conference 'The Physical Chemistry of Iron and Steelmaking', 1956, $55-62$.

[93] Turkdogan ET. Physiochemical properties of molten slags and glasses. ISBN 0904357546, London, 1983.

[94] Dingwell DB. Viscosity and anelasticity of melts, in: Mineral Physics and Crystallography, A Handbook of Physical Constants, pp. 209-17, 1995.

[95] Mills KC. Estimation of physicochemical properties of coal slags and ashes. In: Mineral matter and ash in coal, pp. 195 - 214 (Ed. K.S. Vorres) ISBN 0841209596, 1986.

[96] Kleinhans U, Wieland C, Frandsen FJ, Spliethoff H. Ash formation and deposition in coal and biomass fired combustion systems: progress and challenges in the field of ash particle sticking and rebound behavior. Prog Ener Combust, 2018, 68, 65 - 168.

[97] Zhengh F. Thermophoresis of spherical and non-spherical particles: a review of theories and experiments. Adv Colloid Interfac, 2002, 97, 255 - 78. 
[98] Baxter L. Advanced chemical analysis as indicators for coal slagging and fouling. Presented at the $21^{\text {st }}$ annual ACERC conference, February $28^{\text {th }}, 2007$.

[99] Yang X, Ingham D, Ma L, Zhou H, Pourkashanian M. Understanding the ash deposition formation in Zhundong lignite combustion through dynamic CFD modelling analysis. Fuel, 2017, $194,533-43$.

[100] Zbogar A, Frandsen F, Jensen PA, Glarborg P. Shedding of ash deposits. Prog Ener Combust, 2009, 35, $31-56$.

[101] Nowok JW. Densification, shrinkage and strength development in selected coal ashes. J I Energy, 1996, 69, 9-11.

[102] Piroozmand F, Tran H, Kaliazine A, Cormack D. Strength of recovery boiler fireside deposits at high temperatures. Proceedings of 1998 Tappi Engineering Conference, pp. 169 179, 1998.

[103] Raask, E. Erosion wear in coal utilization. ISBN 3540186018, Hemisphere, New York, 1988.

[104] Oka YI, Okamura K, Yoshida T. Practical estimation of erosion damage caused by solid particle impact: Part 1: Effects of impact parameters on a predictive equation. Wear, 2005, 259, $95-101$.

[105] Zbogar A, Jensen PA, Frandsen FJ, Hansen J, Glarborg P. Experimental investigation of ash deposit shedding in a straw-fired boiler. Energ Fuel, 2006, 20, 512 - 519.

[106] Stitt S, Junker H, Baxter LL. Optimisation of deposit removal in biofueled boilers: review of control systems, technologies and mechanisms. Eltra, Project No. 3144; 2002.

[107] www.clydebergemann.de visited January 2008. 


\section{$3 \quad$ REVIEW OF MODELS AND TOOLS FOR SLAGGING AND FOULING PREDICTION FOR BIOMASS CO-FIRING}

\subsection{Introduction}

Principal types of biomass materials that are utilised in industry in significant quantities are listed in Table 3.1. The majority are waste and residue materials from agricultural, forestry and industrial activities. In most cases, these materials are traditionally left in situ or sent for disposal to landfill. There, they will be subject to microbial respiration and other processes, which release greenhouse gases into the atmosphere.

In recent years, the value of biomass as a renewable fuel has been increasingly recognised, and they are being collected, processed, if necessary, and delivered as fuel for utilisation in combustion and other thermal processing plants. An increasing number of dedicated biomass power plants are being built worldwide, and the level of biomass co-firing activity at the coal-fired power plants is also increasing. There is also an increasing international trade in biomass materials for use as fuel for the generation of power and heat.

To date, much of the biomass co-firing in large coal-fired utility boilers has been at relatively low co-firing ratios (in most cases up to $20 \%$ mass based), and the impact on boiler performance and integrity have, in general, been modest. With increased co-firing levels, the impacts on plant performance and integrity will become more significant, particularly with the lower grade biomass materials. Principal technical concerns are associated with the behaviour of the mixed coalbiomass ashes, and there are significant concerns about the potential impacts of ash deposition on surfaces in the boiler and associated equipment. 
Table 3.1 The major biomass materials of industrial interest on a worldwide basis.

\begin{tabular}{|c|c|c|c|}
\hline Agricultural products & Forestry products & Wastes & Energy crops \\
\hline Harvesting residues & $\begin{array}{l}\text { Harvesting } \\
\text { residues }\end{array}$ & Domestic/industrial & Wood \\
\hline Cereal straws & Forestry residues & Municipal solid waste (MSW) & Willow \\
\hline Oil seed rape and & & Refuse-derived fuels & Poplar \\
\hline linseed oil straws & & Construction and demolition & Cottonwood \\
\hline Flax straw & & wood wastes & \\
\hline Corn stalks & & Scrap tyres & \\
\hline & & Waste pallets & \\
\hline Processing residues & $\begin{array}{l}\text { Primary processing } \\
\text { wastes }\end{array}$ & Urban green wastes & $\begin{array}{l}\text { Grasses and } \\
\text { other crops }\end{array}$ \\
\hline Rice husks & Sawdusts & Leaves & Switchgrass \\
\hline Sugarcane bagasse & Bark & Grass and hedge cuttings & Reed canary \\
\hline Olive residues & Offcuts & & grass \\
\hline Palm oil residues & & & Miscanthus \\
\hline \multicolumn{4}{|l|}{ Citrus fruit residues } \\
\hline \multirow[t]{2}{*}{ Animal wastes } & Secondary & & \\
\hline & processing wastes & & \\
\hline Poultry litter & Sawdusts & & \\
\hline Tallow & Offcuts & & \\
\hline Meat/bone meal & & & \\
\hline
\end{tabular}

Operational problems associated with the deposition and retention of ash materials can and do occur on all of the major gas-side components of combustors and boilers. The more important high temperature occurrences in the more common solid fuel combustion systems are associated with the following:

- The partial fusion and agglomeration of ash particles in the fuel beds of stoker-fired and fluidised bed-fired combustors can lead to poor combustion conditions and de-fluidisation of fluidised beds, and can cause problems with the ash removal system and with the downstream ash handling equipment.

- The deposition of fused or partly-fused ash materials on burner component and divergent quarl surfaces in large pulverised fuel furnaces can result in interference with burner lightup and other operational difficulties, and can affect combustion performance.

- The build up of large accumulations of fused and partially-fused ashes can interfere with the operation of stokers and fluidised bed combustors, and can block ash hopper throats 
in pulverised fuel-fired furnaces. This can result in a requirement for load reduction or can lead to significant unplanned outages for off-load cleaning.

- The deposition of fused or partially-fused slag deposits on furnace heat exchanger surfaces reduces furnace heat absorption, and leads to increased gas temperatures both within the furnace and at the furnace exit. This, in turn, can lead to increased ash deposition and high metal temperatures in the convective sections of boilers, and it may be necessary to reduce load or to come off load for manual cleaning.

- The accumulation and subsequent shedding of large ash deposits on upper furnace surfaces can lead to damage to grates and to furnace ash hoppers, and to the defluidisation of bubbling fluidised beds.

These are slag formation processes which generally occur at relatively high temperatures in excess of around $800-1,000^{\circ} \mathrm{C}$, on refractory or water wall surfaces in the furnace which are in direct receipt of radiation from the flame. They occur relatively rapidly, over a matter of minutes or hours, when conditions are favourable. They usually involve the sintering and (partial) fusion, of fuel ash particles within the furnace.

The accumulation of ash deposits in the convective sections of boilers also occurs. These ash accumulations are normally termed fouling deposits, and the more common occurrences include:

- The formation of ash deposits on the surfaces of superheater, reheater and evaporator banks occurs at flue gas temperatures less than around $1,000-1,100{ }^{\circ} \mathrm{C}$. This is generally a much slower process than slag formation, and the tendency is for significant ash deposits to grow over a period of a number of days. The process involves the formation of deposits in which the ash particles are bonded by specific low melting point constituents, principally the alkali metal species. The gas temperature is generally too low for significant sintering or fusion of the bulk of the ash particles to occur. As the gas temperature decreases in the boiler convective section, the deposits tend to be less extensive, and to be less well bonded and physically weaker. This is commonly reflected in the design of the boiler convective section, i.e. it is often possible to reduce the cross pitches of the tube banks progressively as the flue gas temperatures decrease.

- Convective section fouling is one of the most troublesome ash-related problems associated with the combustion and co-firing of biomass materials, because of the relatively high alkali metal contents, and hence high fouling potential, of many biomass materials. Fouling reduces the heat absorption in the convective banks, and results in increased flue gas temperatures. Fouling also increases the gas-side pressure drop across the banks, and can eventually lead to ash bridging between the tubes. This further increases the gas side pressure drop, and can result in the channelling of the flue gas. The increased flue gas velocity can result in local overheating of the heat exchange tubes, and in localised damage to boiler tubes and other components by particle impact erosion. 
- The ash deposits on economiser surfaces form at low flue gas temperatures and tend to be relatively weakly bonded. They are commonly initiated by the physical accumulation of ash, often by the gravitational settling of ash material. This material has been dislodged from primary deposition sites upstream of the economiser by the action of sootblowers.

- Low temperature fouling and corrosion of air heater surfaces are also common occurrences. This is a complex process, that can involve both ash deposition and the condensation of acid gas species on cold surfaces, and they tend to be very specific to the design and operation of the air heater.

It is clear, therefore, that the ash deposition process occurring on furnace and boiler surfaces is a complex phenomenon. The process occurs over a wide range of flue gas and surface temperatures, and is dependent both on the characteristics of the ash and on the design and operation conditions of the combustor or boiler plant.

The principal objective of this chapter is to present a short overview of the existing models and tools, which have been developed largely for pulverised coal combustion systems, and to review their application for the description and prediction of the slagging and fouling behaviour of the biomass ash and the mixed coal-biomass ashes in biomass firing and co-firing applications.

An overview of the principal technical approaches that have been taken to the predictive modelling of the extent and location of ash deposition in furnaces and boilers is presented in Section 3.2 of this chapter. In Section 3.3, there is a discussion of a number of the more important on-line diagnostic methods that are available for the monitoring of ash deposition in boilers, and of the use of the results of these methods to provide predictions of the extent and distribution of ash deposits by means of neural networking. The application of these methods to the mixed ashes produced by the co-firing of biomass with coal is discussed in Section 3.4.

\subsection{Predictive methods for ash deposition}

In general terms, three approaches to the development of predictive models for ash deposition in furnaces and boilers are apparent, viz:

- The empirical approach by traditional methods based on the use of simple Slagging or Fouling Indices, using the data normally available on fuel specifications, i.e. the ash chemical composition and the ash fusion temperatures. These relatively simple, practical methods are used by designers and operators, particularly when no fuel sample for more detailed analysis is available, as input to their normal design or fuel assessment procedures.

- The mechanistic approach involves the use of relatively simple models of the combustion and other processes that may occur in combustors and boilers, in an attempt to provide a 
general assessment of the ash deposition tendency and the nature of the ash deposit in a specific application.

In principle the more advanced models based on computational fluid dynamics (CFD) can provide detailed information about the combustion process and the fluid dynamics. For the simulation of ash deposition processes, the CFD models have sub-models of the ash transformation process, particle deposition and adhesion and the impacts on heat transfer. The individual approaches are discussed in the next sections.

\subsubsection{The empirical approach}

\subsubsection{Ash fusibility}

The fusion behaviour of solid fuel ashes is an important factor in determining the propensities of the fuels to form fused or partly-fused slag deposits on the reactor surfaces in all thermal processors systems and, in some circumstances, may have an influence on the nature of the fouling deposits that can occur on the heat exchange and other surfaces. The fusion behaviour of most fuel ashes is a fairly complex phenomenon, which is best described in terms of a melting curve, where the percentage of the ash, by mass, which is fused is plotted against the temperature. On full ash melting curves, two key temperatures are commonly identified, and can be used to describe the physical behaviour of the ashes, viz:

- the $T_{15}$ temperature is the temperature at which $15 \%$ of the ash material by mass is molten. This is considered to be the temperature at which the surfaces of the ash particles or slag deposits begin to become sticky and receptive to the adhesion of solid particles, and

- the $\mathrm{T}_{70}$ temperature is the temperature at which $70 \%$ of the ash material by mass is molten. This is the temperature at which the outer surface of an ash deposit on a vertical surface will begin to flow under the action of gravity.

The determination of full melting curves for ashes is a very time-consuming exercise. The standard Ash Fusion Test, which has been applied for the characterisation of the fusion behaviour of coal ashes for many decades, is much simpler and is based on the determination of three or four key temperatures on the melting curve. This procedure has been developed and applied specifically for aluminosilicate, coal ash systems, which have very complex melting behaviour. Coal ash systems commonly melt over a fairly wide range of temperatures from around $1,000-1,500^{\circ} \mathrm{C}$, and tend to produce relatively viscous melts.

The results of the application of this test procedure to biomass ashes, most of which are not aluminosilicate systems, and many of which melt at temperatures less than $1,000{ }^{\circ} \mathrm{C}$, are of technical interest, but should be treated with great caution. There have been several attempts to develop correlations between the ash fusion temperatures and the ash chemical composition for 
coal and biomass ashes. These can be of some technical value in a general sense; however they tend not to be reliable or accurate enough for predictive purposes.

\subsubsection{Ash deposition indices}

A number of Slagging and Fouling Indices are available for the assessment of the propensity of fuel ashes to form deposits, in combustors and in the convective sections of boilers. A detailed description of the technical basis and use of a number of these indices is presented in reference [1]. These indices are based either on the fuel ash content and the ash chemical composition, or on the results of the Ash Fusion Test. In the main, these indices have been developed for the assessment of coal ashes, and have been applied, with appropriate modifications, to the ashes from other solid fuels, including wastes and biomass materials, and to the mixed ashes produced by the co-processing of biomass materials with coal.

The majority of the Slagging Indices are concerned with the prediction of the fusion behaviour of the ash, and are based either on the results of Ash Fusion Test or on the chemical composition of the ash, commonly the ratio of the acidic metal oxides, $\left(\mathrm{SiO}_{2}\right.$ and $\left.\mathrm{Al}_{2} \mathrm{O}_{3}\right)$ to the basic oxides $\left(\mathrm{Fe}_{2} \mathrm{O}_{3}, \mathrm{CaO}, \mathrm{MgO}, \mathrm{Na}_{2} \mathrm{O}\right.$ and $\left.\mathrm{K}_{2} \mathrm{O}\right)$. These indices provide a general assessment of the fusion behaviour of an ash, which is then employed to rank the ash in terms of its propensity to form fused or partially-fused agglomerates and slag deposits. Despite the recognised technical limitations of both of these approaches, they are still used widely within the industry for fuel specification, furnace, reactor and heat exchanger design and for plant operational purposes.

A number of more sophisticated approaches to the assessment of the slagging propensity, for instance based on the use of phase diagrams of the appropriate aluminosilicate systems, or on the use of mineralogical analysis data derived from the characterisation of the fuel using scanning electron microscopes and other advanced techniques, have been developed. These have, however, enjoyed only relatively limited use within the industry, principally because they are less familiar and more complicated than the traditional methods and some need access to specialised equipment. These methods are more often used for investigative purposes.

Since the majority of the coal ash slagging indices are based on the assessment of the fusion behaviour of aluminosilicate coal ashes, the application to biomass ash systems, which are chemically very different, can be problematic, and great care should be applied when interpreting the conventional Slagging Index values for biomass ashes and to the ashes produced from the co-processing of biomass materials with coals.

When considering the potential slagging behaviour of the mixed ashes from the co-processing of biomass with coal, it is clear that, apart from $\mathrm{SiO}_{2}$, all of the significant chemical constituents of most biomass ashes, and principally the alkali and alkaline earth metals, are powerful fluxes for aluminosilicate systems. It is expected, therefore, that the co-processing of biomass with coal will 
tend to result in a significant reduction in the fusion temperatures, and hence an increase in the slagging potential. This will, of course, depend on the level of fluxing agents already present in the coal ash and on the co-firing ratio. It has been found that the effect is much more dramatic when biomass is co-processed with coals with high fusion temperature ashes, since the effect of adding fluxing elements to a coal ash with low levels of the fluxing elements tends to be much greater than adding fluxes to a coal with lower ash fusion temperatures and hence higher levels of fluxing elements.

For the co-processing of biomass with coal at relatively low levels, say less than $10-20 \%$ or so on a mass basis, the mixed ash is still predominantly an aluminosilicate system, and the normal coal slagging assessment methods can generally be applied, with some confidence.

The most commonly applied Fouling Indices for coal ashes are, in the main, based on the sodium content of the fuel. The technical reason for this is that the deposition of the sodium compounds in the fuel by a volatilisation/condensation mechanism is considered to be the principal driving force for heat exchanger fouling in coal plants. The majority of the potassium in coal ashes is present as a constituent of the clay minerals, and is not considered to be available for release by volatilisation in the flame to the same extent. The existing indices, developed for coal ash, are inaccurate when applied to the prediction of a biomass ash melting point [2].

For most biomass materials, potassium tends to be the dominant alkali metal, and this is generally in a form that is considered to be available for release by volatilisation. The fouling indices which have been developed specifically for the assessment of biomass materials tend, therefore, to be based on the total alkali metal content of the fuel (see, for instance, [3]).

For the co-firing of biomass with coal, some combination of the two methods should be applied, and this assessment should always be carried out with great care.

\subsubsection{The mechanistic approach}

\subsubsection{Comprehensive prediction models}

A number of reviews of the development of models for the prediction of ash deposition in coal boilers have been published (for instance, [4], and the references cited therein). The majority of the models are mechanistic in nature, and attempt to provide descriptions of some or all of the following processes:

- Fuel and mineral matter characteristics,

- Fuel combustion, ash formation processes and the ash particle characteristics,

- Fluid dynamics and particle transport,

- Particle impaction and adhesion, 
- Deposit growth rate as a function of the ash characteristics, the conditions at the deposition site and time,

- Deposit properties and strength development,

- Heat transfer through the deposit,

- The effect of deposition on operating conditions (e.g. temperatures and heat fluxes), and

- The deposit structure and its effect on gas flow patterns.

A schematic diagram which describes the general approach that has been taken to the development of mechanistic models of the ash formation and the ash deposit formation processes, based on this general process scheme is presented in Figure 3.1, below.

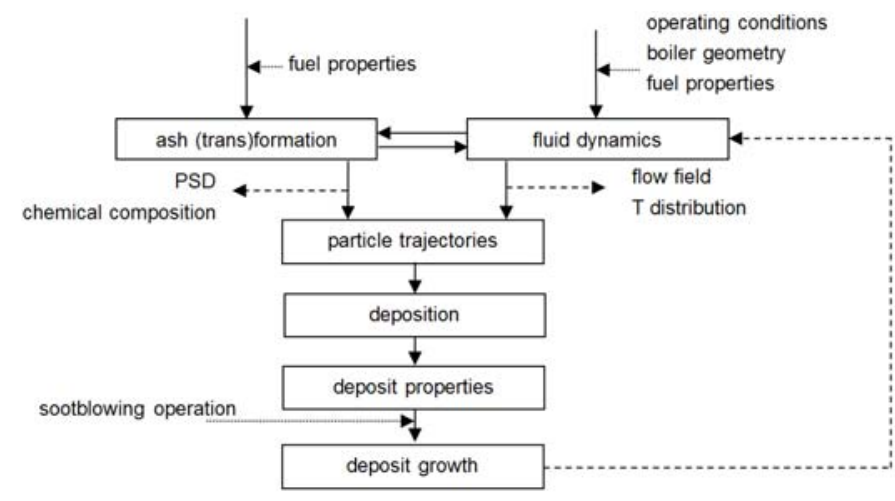

Figure 3.1 Comprehensive modelling approach.

\subsubsection{Fuel particle combustion and ash formation}

An ash formation model which provides predictions of the chemical composition and particle size distribution of the fly ash particles is required. These models require detailed input on the physical and chemical properties of the fuel particles and the associated mineral material. This most commonly derived from the data available from computer-controlled scanning electron microscopic examination (CCSEM) of the pulverised fuel. They normally incorporate a model of the combustion of the coal particles and the fractionation and coalescence behaviour of the ash particles in the flame, which generates a description of the particle size distribution and the chemical compositions of the fly ash particles. The general scheme of these processes is illustrated schematically in Figure 3.2. 


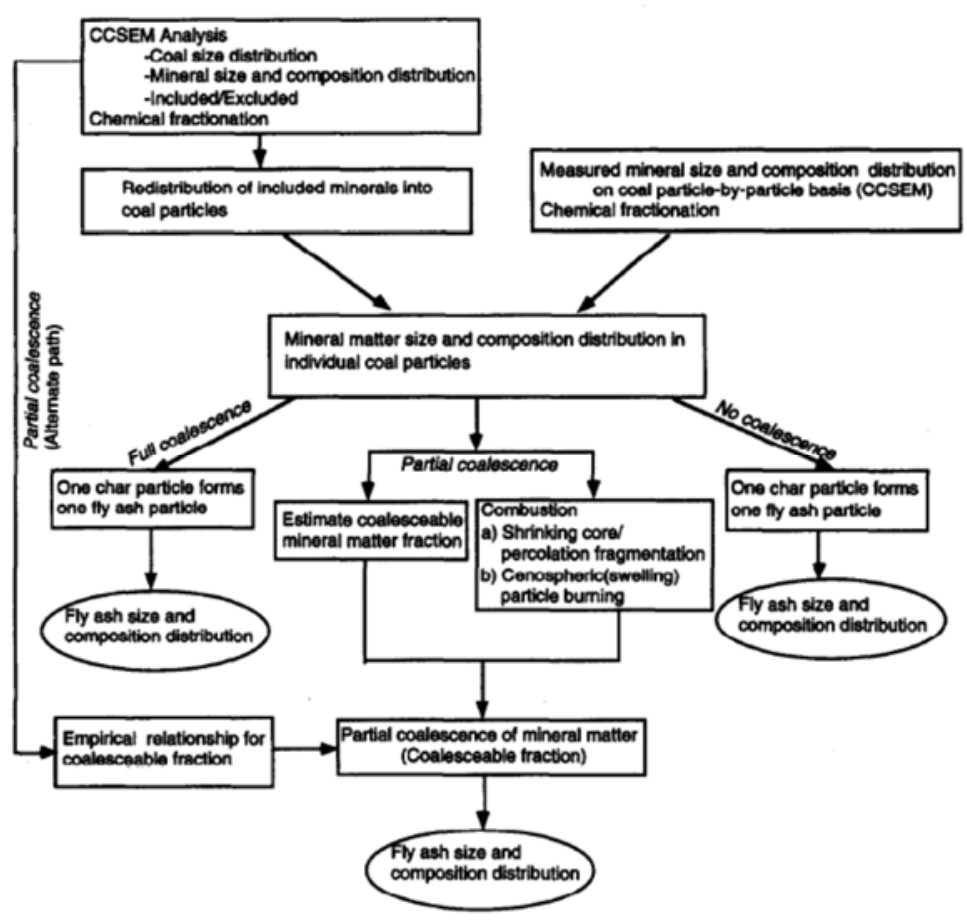

Figure 3.2 General algorithm for ash transformations, using CCSEM as input source: [4].

In an article by Yan et al. (2002) [5], the ash particle fragmentation was simulated using a Poisson distribution method. The coalescence of the included mineral occurrences was treated similarly to char combustion, i.e. using a shrinking core model. Baxter et al. (1991) described the development of an alternative approach using standard ASTM analyses and chemical fractionation data rather that CCSEM data [6]. Using this approach, the key chemical elements are allocated to one of thirteen different mineral groups whose behaviour as a function of the residence time and temperature is relatively well understood.

\subsubsection{Computational Fluid Dynamics (CFD)}

In recent years, a number of attempts have been made to utilise CFD methods to model the ash formation and transport processes in pulverised fuel and fluidised bed combustion systems ([7], [4], [8], [9], [10], [11], [12], [13], [14]). This type of modelling offers the prospect that it can take into account local conditions within the furnace and boiler, and that it may be possible to simulate the consequences of changes in the plant operating conditions. In the majority of these models, a number of key phenomena are considered, [10], viz:

- turbulent fluid flow,

- gas and particle combustion,

- heat release and heat transfer, and 
- $\quad$ ash particle transport.

When a converged steady-state solution is obtained, the ash particle fluxes to the boiler surfaces and the deposit growth rate is calculated as a "post-processing" calculation.

\subsubsection{Deposition modelling}

A number of particle transport or deposition mechanisms can be responsible for the build up of a deposit layer on the surfaces on the furnace walls or on a convective pass tube, depending on the concentration, size and chemistry of the fly ash particles, the nature of the surface and the local physical conditions, viz:

- Inertial impaction,

- Thermophoresis,

- Eddy and Brownian diffusion,

- Condensation, and

- Heterogeneous reactions of deposit constituents, generally with acid gas species in the flue gases.

One of the more common approaches to the modelling of the deposit build-up with time [10] is illustrated in Figure 3.3.

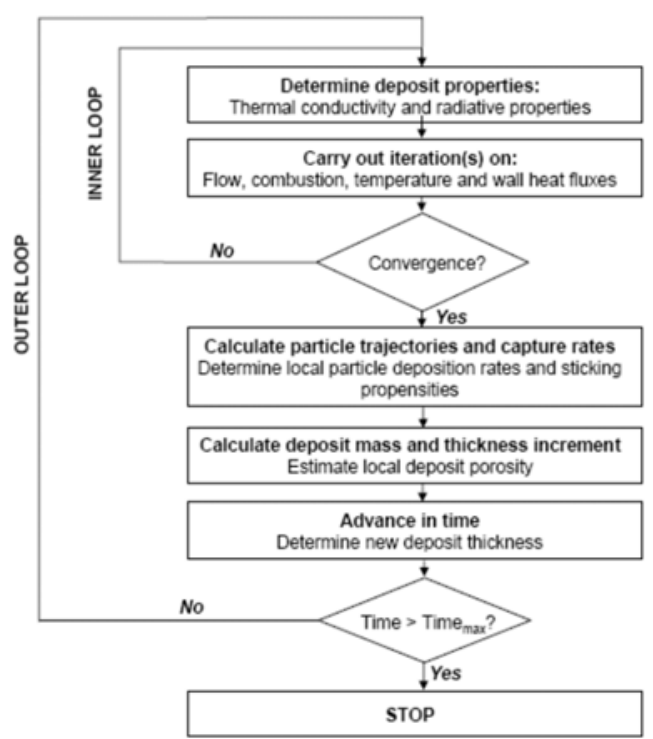

Figure 3.3 Flow chart of deposition model concept with advancement in time; source: [10]. 
The inertial impaction of fly ash particles on the growing deposit surface is most often the dominant process for slag formation processes within the furnace, and this is relatively easily described [15]. The impaction efficiency can be written, for instance as a function of the effective Stokes number. The efficiency of subsequent adhesion of the incoming particles is commonly described using the viscosities of the particles and of the surface of the growing deposit. Several models of the particle adhesion processes have been developed [16].

Thermophoresis is generally important only at very low deposition rates, e.g. for the initial ash deposit [17] when the boiler tubes are clean and new. According to Baxter (2007) [15], there is a lot of potentially useful theory available to describe thermophoresis processes; however the results have not so far been very satisfactory.

Condensation, particularly of alkali metal species, is a key process during the very early stages of slag deposit formation on clean furnace tubes, and in the formation of convective pass fouling deposits, where temperatures are too low for fusion of the bulk ash material. The theory of condensation is available, but is rather complex for practical applications. Recently, a model has been presented for condensation of alkali salts for practical application in full-scale boiler models (without resolving the boundary layer), see [18].

The key chemical reactions involved in ash deposit growth are sulphation, alkali absorption and oxidation. They add to the mass of the deposit and may increase deposit strength due to recrystallisation. These are complex to describe in the condensed phase [15].

It is clear from the above, therefore, that there are significant difficulties associated with the modelling of the deposit growth and strength development processes for processes primary deposition sites, i.e. where the deposit growth involves the addition of coal fly ash particles to the deposit. Deposition processes which involve the shedding or migration of the deposited ash material, and which may result in subsequent deposition of ash deposit material at a secondary site, can be very important in the development of mature ash deposit patterns in boilers. These processes, however, have not been extensively studied are not well understood. They are generally not covered by the current models.

Uncontrolled ash deposition, with no shedding or deposit removal would, in most plants firing solid fuels, very quickly result in significant operational problems. The majority of solid fuel furnaces and boilers are fitted with on-line cleaning systems of various types to permit a level of control over the extent of ash deposition in key areas of the plant. There are also natural ash deposit shedding mechanisms and other processes which are responsible for the reduction in the extent of deposition.

The key processes responsible for the shedding of ash deposits include the following: 
- The principal means of the on-line control of ash deposit growth in most solid fuel-fired furnaces and boilers is the use of the installed sootblowers or lances. These devices direct a high velocity jet of steam, water or compressed air at the deposits, and employ a combination of mechanical impact and thermal shock to break up and remove the deposits. Sonic sootblowers can also be deployed, particularly for the dislodging of relatively weak deposits in the cooler parts of the boiler convective section. In extreme circumstances, where very tenacious and troublesome ash deposits have formed, small explosive charges and blasting cord have been employed to break up the deposit material.

- The deposit material removed in this way may be carried forward with the flue gases, but can also accumulate elsewhere in the furnace, or in the convective pass of the boiler, where the tube pitches may be narrower.

- The natural shedding or detachment of deposits also occurs. This can occur when deposits grow too large for the adhesive forces to support them, or due to the effect of thermal expansion differences between the ash deposit and the boiler tube, during shutdowns and boiler load changes. Rapid boiler/combustor load changes, or periods of firing low ash fuels such as oil or gas, can be deliberately used to encourage these processes, for deposition control.

- The detachment of large accumulations of slag in this way can, however, result in damage to components or in troublesome accumulations of ash lower in the furnace.

- Heavily fused deposits of low viscosity can drip on to surfaces lower down in the furnace or boiler.

- In extreme circumstances it may be necessary to reduce load or to come off load for manual cleaning of the boiler in order to get the extent of ash deposition under control.

- In the boiler convective section, fly ash particle impact erosion wear can result in the reduction of the thickness of fouling deposits, particularly on the sides of tubes.

Clearly, both secondary ash deposition and deposit shedding processes are of importance in the development of mature slagging and fouling deposits within boilers. This has been recognised only recently and it is clearly very difficult to model these processes in a practically meaningful way.

The first serious attempt to describe these processes in a systematic fashion is presented in a review by Zbogar et al. (2009) [19]. A number of deposit shedding mechanisms, both natural and artificial, were identified. The general conclusion was that the fundamental knowledge of the key shedding mechanisms and of the relevant properties of the ash deposits is limited, and apart from the specific issues associated with the operation of kraft recovery boilers, no serious attempt to model these processes has been made. This represents a major barrier to the development of practically useful predictive models for ash deposition in solid fuel-fired boilers. 
An in-depth review of (numerical) modelling of particle sticking, rebound, removal, ash deposit morphology is given by Cai et al. (2018) [20].

\subsubsection{Thermodynamic equilibrium modelling}

In addition to the conventional ash chemical analysis and ash fusion tests, a number of other techniques are used to characterise the behaviour of fuels ashes. The use of chemical fractionation techniques, for instance, which were developed originally for the characterisation of the inorganic components of coals, has also been applied to the characterisation of biomass materials. The procedure normally involves the treatment of a small sample of the fuel by a standardised leaching process, with a series of progressively more severe chemical reagents. The leaching reagents employed for this purpose are commonly:

water $\rightarrow$ ammonium acetate solution $\rightarrow$ hydrochloric acid solution.

Four fractions are obtained, as described in Figure 3.4, viz:

- The water-leachable components which, in most cases, are principally the alkali metal salts, sulphur and chlorine compounds,

- The acetate-leachable components, which are generally associated with the organic fraction of the fuel, i.e. are present as in the fuel in the form of cations and chelates,

- The acid-leachable components, i.e. generally the carbonates and sulphates, and

- The solid residue, principally silica, silicates and other mineral species insoluble in mineral acids.

It is generally considered that the water and acetate-leachable elements are those that are likely to be more readily released into the vapour phase, and which may tend to form the very finest aerosol fraction of the ash generated from the biomass at elevated temperatures. The acid soluble and solid residue fractions are not considered to be available for release into the vapour phase during most thermal processes, and tend to report to the coarser fractions of the ashes.

In general, the general results of chemical fractionation tests on solid fuels can be summarised as follows:

- For bituminous coals, very little of the inorganic material in the fuel, and generally only the sodium chloride, is found in the water and acetate soluble fractions.

- For lignites and peat, a higher level of water and acetate soluble material, with some of the calcium in the acetate soluble category, is commonly found.

- The biomass materials, in general, have significantly higher levels of water and acetate soluble material, with the majority of the potassium and chloride, and some of the calcium and magnesium, being in this category. 
Clearly, the chemical fractionation techniques can provide some useful, general information about the nature and potential behaviour of mineral material and ashes in combustion and other thermal processing plants. It is also clear, however, that the procedure has a number of important limitations and the results should be interpreted very carefully. These techniques are also relatively time-consuming and expensive to perform, and are employed principally for research and investigative purposes.

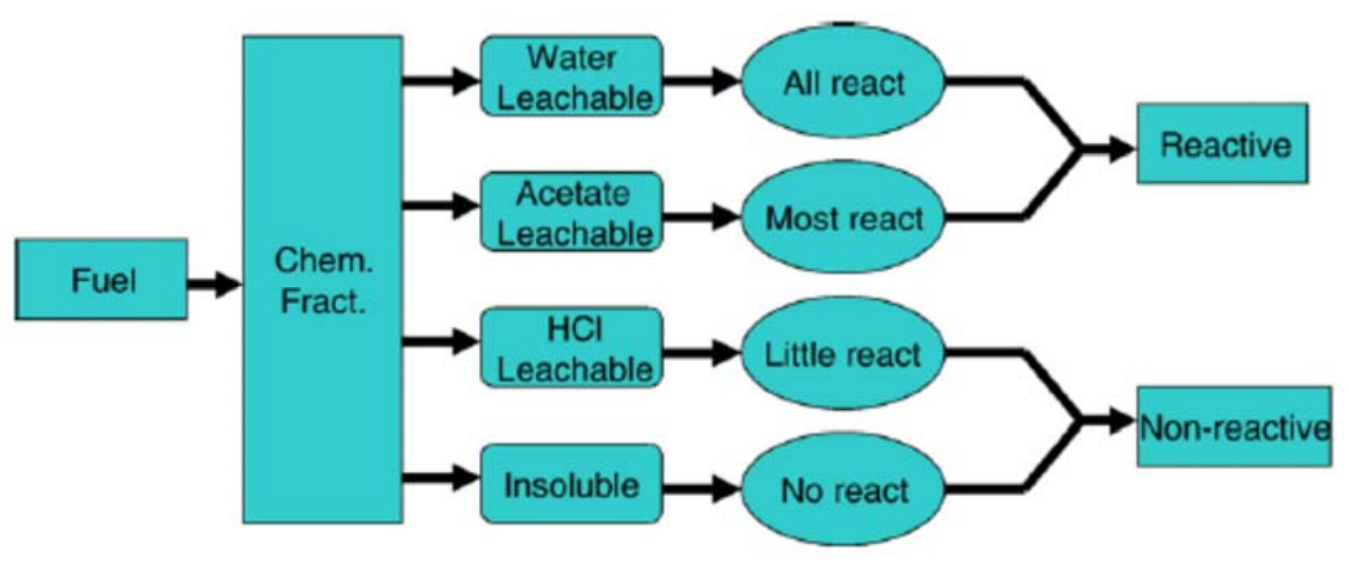

Figure 3.4 Definition of reactive and non-reactive fractions from Chemical Fractionation analysis. Source: [21].

In thermodynamic equilibrium modelling of ash behaviour, the reactive fraction from the chemical fractionation test is used as input for the thermodynamic equilibrium calculations of the deposit formation processes, whereas the non-reactive fraction is considered as being relatively inert.

This approach was adapted by Nutalapati et al. (2007) to allow for interactions between the gas phase alkali metals and silica particles at elevated temperatures [21]. They investigated the effect of regarding the $\mathrm{HCl}$ leachable fraction and the non-leachable fraction as partly reactive, and considered that the outer layer of the quartz particles after reaction with the alkali metals, to produce a surface layer of alkali metal silicates of lower melting temperatures, could be regarded as being reactive.

This concept is illustrated in Figure 3.5. Assuming spherical particles with a diameter of $10 \mu \mathrm{m}$, an active surface layer of $1-5 \mu \mathrm{m}$ in thickness would result in $5-25 \%$ of the acid/non leachable fraction by weight being in the reactive category. 


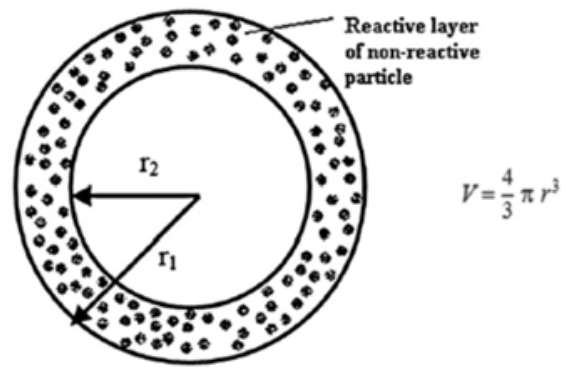

Figure 3.5 Spherical ash (silica) particle with outer (molten) reactive layer; source: [21].

There is experimental evidence, for instance, that significant reaction between the alkali metals in the vapour phase and the silica particles, during the combustion of wheat straw, occurs at temperatures in excess of $1,300{ }^{\circ} \mathrm{C}$, according to measurements made by Lindner and Wall (1990) [22].

For ash deposition processes in biomass firing and co-firing situations, the models have to describe the non-ideal behaviour of aluminosilicate slags, alkali metal silicates and molten alkali salts. The key modelling approach makes use of the FactSage code. For liquid phases with strong interactions among the atoms, which is the case in silicate slags, strong short-range ordering occurs, so there is no random distribution of the atoms. The modified quasi-chemical model is applied to take this in account. Molten salts are described in FactSage using sub-lattice models. For details of the results of this type of modelling work, see references [23], [24], [25], [26], [27] and [28].

It is clear from the published work to date that the thermodynamic equilibrium modelling of the complex ash generation and deposition processes taking place in the combustion systems and boilers is very difficult. It is also clear that some processes will be kinetically controlled. The incorporation of reaction kinetics into the models will require exhaustive knowledge of the reactions, and this is not available for all of the relevant processes. The use of equilibrium calculations is considered to provide an "educated guess" and this is current common practice.

It should be noted in this context that the heating rates in the flame zones of pulverised fuel boilers are of the order of $10^{3}-10^{5} \mathrm{Ks}^{-1}$, and that the particles and flue gases have residence times of a second or two in the flame, a few seconds within the furnace, and tens of seconds in the boiler. It is recognised that the equilibrium state is not completely reached in boiler processes, especially for $\mathrm{CO}_{2} / \mathrm{CO}, \mathrm{SO}_{2} / \mathrm{SO}_{3}$, and for a number of the trace elements like $\mathrm{Hg}$. Equilibrium calculations can provide, at best, an alternative means of studying the key ash formation and deposition processes, and this can be of some benefit in certain circumstances. 


\subsection{The on-line measurement and prediction of ash deposition}

The control of ash deposition in solid fuel-fired combustors and boilers is a fairly complex issue, involving fuel diet, boiler design and operational factors. The key factors are:

- The careful design of the furnace and boiler convective section, which recognises properly the characteristics and behaviour of the fuel ashes, is of prime importance, and the equipment supplier obviously has the key role in this regard. The incorporation of specific furnace and boiler design features, where appropriate, to minimise ash deposition, to aid the removal of ash, and to avoid ash accumulation within the system, is obviously of key importance.

- The correct design, operation and maintenance of the combustion equipment and of the online cleaning systems are important issues. It is usually preferable to minimise the risks of excessive deposition by maintaining the furnace and boiler surfaces at a relatively low level of deposition, rather than deploying the on-line cleaning systems only when there is evidence of significant ash deposition. The intensive cleaning of the furnace and boiler surfaces during boiler outages can be very effective in increasing the operating times between forced outages for manual cleaning, particularly in situations where the control of the ash deposition is a significant operational issue.

There are specialised on-line deposition monitoring and sootblowing control systems, that are commercially available, and that can assist with the optimisation of the sootblower operations and the control of ash deposition. These systems are designed principally for the control of deposition in the larger industrial and utility fossil fuel-fired boilers. Systems are available for the control of ash deposition in both the furnace and the convective sections, and for optimisation of the boiler performance. These systems are generally based on the on-line measurement of the temperatures or heat fluxes at the furnace walls, or on measurement of the heat transfer performance of individual convective banks.

There have been relatively few detailed reports of the systematic testing of the performance of these on-line sootblower optimisation systems. Recently, some comments on the shortcomings of the commercially available systems for the on-line monitoring of ash deposition and the use of the intelligent sootblowing systems, were published by Terual et al. (2005) [29]. The comments included:

- The vendors of the on-line systems, in some cases, claim exaggerated benefits for their products, often on the basis of the results of plant trials, however very little impartial and authoritative technical information on the effectiveness of these systems has been published in the open literature,

- Most of the on-line systems provide only very simple estimates of the fouling factors, and apply only a very crude approach to the optimisation of the sootblower operation, 
- The interpretation of the outputs of the on-line monitoring with reasonable repeatability is somewhat difficult, bearing in mind the uncertainty in the measurement of plant data, and the variability of the feedstock;

- The optimization of on-line cleaning systems requires effective monitoring of deposit growth and the prediction of the future evolution of the deposits. This is particularly important for slag formation on furnaces surfaces, since the deposit growth rate is distinctly non-linear. This exceeds the abilities of the current systems.

The authors were clearly sceptical about the effectiveness of the commercial systems currently available for the on-line measurement and prediction of ash deposition. They argued that the preferred option would involve the analysis of the appropriate on-line plant data using neural network methods. Their view was that the conventional statistical tools, such as simple curve fitting, would not be able to cope with the highly dynamic character of ash deposition and the uncertainties associated with the effectiveness of sootblower use.

In this context, there has been growing interest in modern modelling methods. Neural networks, for instance, can provide a more generalised approach to regression analysis that can be particularly useful in situations where the complexity of the problem presents difficulties in terms of the number of relevant factors, and where the use of simplifying assumptions may not be appropriate. The general approach can be described using an example presented by Bhadeshia (1999), see reference [30], as follows.

The solution to a linear regression can be described by the following equation:

$y=\sum_{i} w_{i} x_{i}+c$

where $x_{i}$ represent the major input variables (concentrations, temperatures, etc.) and $w_{i}$ are the associated weighting coefficients. Normally, the solution is obtained by systematically adjusting the values of $\mathrm{w}_{\mathrm{i}}$ and $\mathrm{c}$ until the best fit to the data is found. The correlation can be made both more general and non-linear by defining a hidden node as follows:

$h=f\left(\sum_{j} j w_{j}(1) x_{j}+c\right)$

$y=w(2) h+c(2)$

where $f$ is a non-linear function, and $w(2)$ and $c(2)$ are a new weight and constant, respectively. The output $y$ is, therefore, a non-linear function of $x_{j}$. The function employed within the hidden node is most commonly the hyperbolic tangent, because of its inherent flexibility in this context. Further degrees of non-linearity can be introduced by the combination of more than one hidden node into a more complex network, see Figure 3.6. The resulting quantitative models can be interrogated, and the model parameters can be examined allowing the significance of particular variables to be investigated. 
In the current context, input values, i.e. data such as the plant operating conditions, the fuel analysis, et cetera, are related to output data through a combination of linear and non-linear functions. A data set, commonly called the training set, is used to minimize the error between the calculated and known outputs, prior to the application of the model to the real systems, see Figure 3.6.

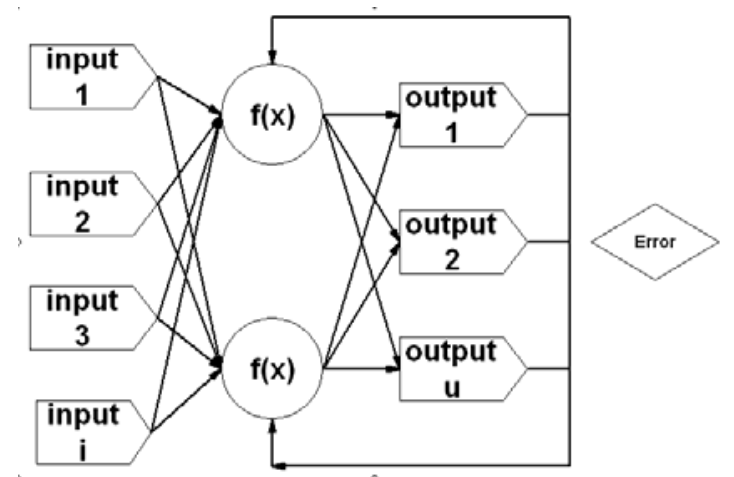

Figure 3.6 Overview of a neural network; source: [31].

As the processes involved in the build up of ash deposits are very complex and highly dynamic, it is probably unreasonable to expect that a network based on simple boiler load, fuel quality parameters, can adequately describe the evolution of deposit build-up. [29] considered, therefore, that it is more appropriate to use the neural network approach to describe simpler subsystems.

The sub-systems used in this case were the sootblower effectiveness, the increase in heat exchanger surface cleanliness after a deposit shedding occurrence, and the increase in the heat flux after a deposit shedding occurrence. These sub-models are relatively simple and are similar in nature, and this helps to simplify the modelling work. The results of this approach, as reported by Teruel et al. (2005) [29] were encouraging, as illustrated in Figure 3.7.

It was demonstrated that, by the detailed analysis of the data collected from an array of thirty heat flux meters arranged across the side and rear walls of the furnace, it was possible to provide a reasonable simulation of the effectiveness of the furnace wall sootblowers and the furnace heat absorption under realistic ash deposition conditions. They considered that this approach may be suitable for the optimisation of the operation of the on-line cleaning systems. 


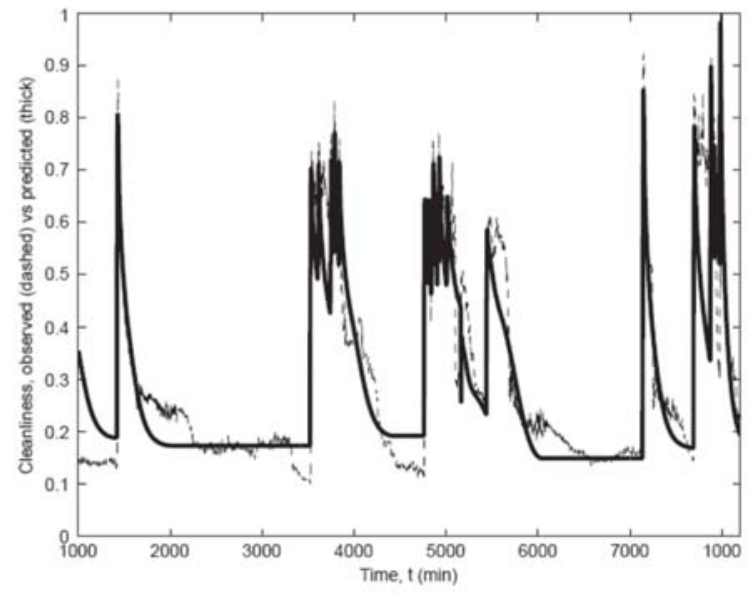

Figure 3.7 Predicted (bold line) versus measured (dotted line) cleanliness, after [29].

\subsection{The application of ash deposition models and assessment methods to biomass co-combustion}

As stated above, the majority of the models and tools have been developed for, and have principally been applied to, the description of ash deposition from pulverised coal combustion. More recently, there has been increasing interest in the co-firing of a wide range of biomass materials with coals, at co-firing ratios generally up to around $20 \%$ by heat input. In a limited number of cases, co-firing at higher ratios, or the full conversion of coal-fired boilers to $100 \%$ biomass, have been successfully achieved.

For coal and biomass firing, and co-firing, there has clearly been significant progress on the development, and the testing and validation, of the methods for the description of the chemical, physical and microstructural characteristics of the parent pulverised fuel particles, and of the evolution of the fly ash particles in the flame, particularly in terms of their size distribution and chemical composition. These developments have been supported substantially by the development and the application of computer-controlled Scanning Electron Microscopes with selected area chemical analysis facilities, and the associated data analysis software, over the past 20 years or so.

There have also been significant developments of the methods available for the computer simulation of the mass transfer processes which may influence the ash particle flux at the primary deposition sites, and, to a lesser extent, of the processes responsible for the adhesion of the oncoming ash particle to the surface of the growing deposit. Despite these developments, the capabilities of the existing models to predict the deposition rates at primary sites are limited, and the current technical approaches to the modelling of the deposit shedding and secondary 
deposition processes, are poorly developed. These are key processes in the development of mature deposits on boiler surfaces. These concerns apply both to the slag deposition in the furnace and the fouling deposits in the convective section of the boiler. Although the basic mechanisms responsible for slagging and fouling are significantly different, both types of deposit are subject to natural shedding processes and sootblowers are applied to control deposit growth in both cases. In both cases, there is a tendency for ash material, detached from the original deposit site, to accumulate at secondary sites.

The development of the predictive models has also been hindered significantly by the practical difficulties in obtaining reliable plant data for model development and validation from operating coal and biomass boilers. These systems are notoriously difficult to study because of the very hostile environment in which the key processes take place.

Overall, the result has been that the attempts to date to develop quantitative predictive models of ash deposition processes in the furnace and convective sections of industrial scale boilers, which can be of value to plant designers and operators, have not met with great success. The models are of significant academic interest, however their use by the industry has been principally for development and investigative purposes.

In the main, therefore, the industry has not made much in the way of practical use of the existing ash deposition models for fuel characterisation, boiler design or operational purposes, and continues to rely predominantly on the more traditional ash ranking methods for the routine characterization of the deposition propensities of coal and biomass ashes, and the mixed ashes generated by biomass co-firing.

As stated above, the measured ash fusion characteristics of a coal, carried out by the standard method, are widely used and are often quoted in coal analyses and specifications. This method has also been employed routinely within the industry to assess the slagging behaviour of biomass materials and biomass-coal mixtures, principally because it is familiar and simple to perform. There have been, however, some technical issues with the application of the procedure to some biomass ashes, and there have been difficulties with the reliability and repeatability of results in some cases.

The tendency towards slag formation is controlled largely by the fusion behaviour of the ash, and this can be assessed using the normal coal ash slagging indices, which are based on the ash chemical composition, or can be measured in the laboratory. For the mixed ashes produced when co-firing, the same technical principles apply. It is generally considered to be legitimate to apply these methods for mixed ashes in the same way as is done for coal ashes, although this should always be done with care. 
For convective pass fouling, the main driving mechanism is the release of alkali metal species in the flame by volatilisation, and the subsequent condensation of the inorganic vapours on cooled boiler surfaces. Again, it is legitimate, with care, to apply the fouling indices available for coals, albeit in a modified form, to take into account the differences in chemistry between coal and biomass materials, or to apply the specific fouling indices for biomass materials, which are based on the total alkali metal content of the fuel per unit mass or per unit of heat content.

It is generally considered to be legitimate, therefore, to apply current boiler design methods, with appropriate modification where necessary, to provide an assessment of the slagging and fouling behaviour of the mixed ashes from co-firing, although it has to be recognised that the risks of obtaining misleading results will increase with increasing co-firing ratio.

\subsection{Summary and conclusions}

To date, much of the biomass co-firing in coal-fired utility boilers has been at relatively low cofiring ratios, less than $20 \%$ on a mass basis, and generally less than that on an asis. The impact on the combustion process, boiler performance, and boiler integrity, has been modest. The current empirical methods for the assessment of the fuel characteristics have proven to be adequate in most instances. With increased co-firing levels, it is anticipated that the fuel-related impacts on plant performance increase. The principal technical concerns are with the behaviour of the mixed ashes and the potential impacts on ash deposition on surfaces in the furnace, the boiler and the associated equipment.

The ash deposition process that occurs when biomass is co-fired with coal, is a complex phenomenon, which occurs over a wide range of flue gas and surface temperatures. The process is dependent on the characteristics of the ash, and on the design and operation of the combustor or boiler plant. The prediction of the growth rate and the nature of the ash deposits for plant design or operational purposes is therefore a complex task.

Traditionally, for routine fuel specification, equipment design and operational purposes, relatively simple empirical methods have been applied. Alternatively, more complex technical approaches to the modelling of these processes have been attempted over several decades. It is fair to say that the deposition models have not been widely adopted for these applications. The use, within the industry, of the predictive models and the associated descriptions of the ash generation and deposition processes, has largely been for development and investigative purposes. The principal reason for this is that the quantitative, predictive capabilities of even the best of the analytical models are limited. It has proven very difficult to provide practically useful simulations of the development of mature ash deposits within the furnace and in the convective sections of a boiler, without proper consideration of natural ash shedding and sootblowing, and of the secondary deposition processes. This has been recognised recently by some of the research 
groups involved in the development of the mechanistic ash deposition models, but, as also described by Zbogar et al. (2009) [19] in a review paper, serious work on the description of the key features of these processes has only just begun.

On a more practical level, there has been significant improvement over the past few years in the techniques available for the monitoring of ash deposition in operating plant and for the optimisation of the use of the on-line cleaning systems. Some of the recent work on the use of on-line plant monitoring with advanced data analysis techniques to predict the effectiveness of the on-line cleaning systems may be of some interest to plant operators, initially to provide additional information to the operating staff, and in time it may be possible to introduce systems for the automatic optimisation of the on-line cleaning equipment.

It is concluded that various relatively simple empirical deposition models have been developed for coal firing applications. More complex models for coal and biomass co-firing applications have been developed or are under development. The deposition models have not been widely adopted for these applications today. In addition, improvement has been made in the techniques available for the monitoring of ash deposition and on-line cleaning systems for the radiative and convective section of a pulverized fuel fired boiler.

\section{References}

[1] Raask E. Mineral impurities in coal combustion, Behavior, problems and remedial measures. ISBN 089116362X, Hemisphere, New York, 1985.

[2] Garcia-Maraver A, Mata-Sanchez J, Carpio M, Perez-Jimenez JA. Critical review of predictive coefficients for biomass ash deposition tendency. J Energy Inst, 2017, 90, 214 - 28.

[3] Miles Sr TR, Miles Jr TR, Baxter LL, Bryers RW, Jenkins BM, Oden LL. Boiler deposits from firing biomass fuel. Biomass Bioenerg, 1996, 10, 125-8.

[4] Wang H, Harb JN. Modelling of ash deposition in large-scale combustion facilities burning pulverized coal. Prog Energ Combust, 1997, 23, 267 - 282.

[5] Yan L, Gupta RP, Wall TF. A mathematical model of ash formation during pulverized coal combustion. Fuel, 2002, 81, 337 - 344.

[6] Baxter LL, Yang NYC, Hardesty DR. Task3: The fate of mineral matter during pulverized coal combustion, min Coal Combustion Science Quarterly Report, January-March, Sandia Report No. SAND91-8217.UC113, 1991. 
[7] Huang LY, Norman JS, Pourkashanian M, Williams A. Prediction of ash deposition on superheater tubes from pulverized coal combustion. Fuel, 1996, 75, 271 - 279.

[8] Lee FCC, Lockwood FC. Modelling ash deposition in pulverized coal-fired applications. Prog Ener Combust, 1999, 25, 117-32.

[9] Mueller C, Skrifvars B-J, Backman R, Nickull S, Hupa M. Simulation of ash particle behaviour on surfaces of biomass fired fluidized bed boilers - combination of computational fluid dynamics and advanced ash analysis. Presented at the $16^{\text {th }}$ International Conference on Fluidized Bed Combustion (Ed. Geiling, D.W.), Reno, Nevada, May 13 - 15, 2001.

[10] Kær SK, Rosendahl LA, Baxter LL. Towards a CFD based mechanistic deposit formation model for straw-fired boilers. Fuel, 2006, 85, $833-48$.

[11] Ma Z, Iman F, Li P, Sears R, Kong L, Rokanuzzaman AS, McCollor DP, Benson SA. A comprehensive slagging and fouling prediction tool for coal-fired boilers and its validation/application. Fuel Proc Tech, 2007, 88, 1035 - 43.

[12] Taha TJ, Stam AF, Stam K, Brem G. CFD modeling of ash deposition for co-combustion of MBM with coal in a tangentially fired utility boiler. Fuel Proc Technol, 2013, 114, 126-34.

[13] Plankenbuhler T, Müller D, Karl J. Slagging prevention and plant optimisation by means of numerical simulation. Presented at the $25^{\text {th }}$ European Biomass International Conference, (Ed, Ek L.), Stockholm, June $12-15,2017$.

[14] Riccio C, Simms NJ, Oakey J. Deposition prediction in a pilot scale pulverized fuel-fired combustor. Fuel, 2019, 253, $1204-13$.

[15] Baxter L. Advanced chemical analysis as indicators for coal slagging and fouling. Presented at the $21^{\text {st }}$ annual ACERC conference, February $28^{\text {th }}, 2007$.

[16] Walsh PM, Sayre AN, Loehden DO, Monroe LS, Beér JM, Sarofim AF. Deposition of bituminous coal ash on an isolated heat exchanger tube: effects of coal properties on deposit growth. Prog Energ Combust, 1990, 16, 327 - 345.

[17] Kleinhans U, Wieland C, Babat S, Spliethoff H. Large Eddy Simulation of a particle-laden flow around a cylinder: Importance of thermal boundary layer effects for slagging and fouling. Fuel, 2019, 241, 585 - 606. 
[18] Kleinhans U, Rück R, Schmid S, Haselsteiner T, Spliethoff H. Alkali vapor condensation on heat exchanging surfaces: laboratory-scale experiments and a mechanistic CFD modeling approach. Energy Fuels, 2016, 30, 9793 - 800.

[19] Zbogar A, Frandsen F, Jensen PA, Glarborg P. Shedding of ash deposits. Prog Ener Combust, 2009, 35, $31-56$.

[20] Cai Y, Tay K, Zheng Z, Yang W, Wang H, Zeng G, Li Z, Boon S, Subbaiah P. Modeling of ash formation and deposition processes in coal and biomass fired boilers: A comprehensive review. Appl Energy, 2018, 230, 1447 - 544.

[21] Nutalapati D, Gupta R, Moghtaderi B, Wall TF. Assessing slagging and fouling during biomass combustion: A thermodynamic approach allowing for alkali/ash reactions. Fuel Proc Tech, 2007, 88, $1044-52$.

[22] Lindner ER, Wall TF. Sodium ash reactions during combustion of coal. Symposium on combustion, 1990.

[23] Pelton AD, Blander M. Thermodynamic analysis of ordered liquid solutions by a modified quasichemical approach - application to silicate slags. Metall Trans B, 1986, 17, 805-15.

[24] Pelton AD. A database and sublattice model for molten salts. Calphad, 1998, 12, 127 - 42.

[25] Pelton AD, Degterov SA, Eriksson G, Robelin C, Dessureault Y. The Modified Quasichemical Model I - Binary Solutions. Metall Trans B, 2000, 31, 651 - 9.

[26] Pelton AD, Chartrand P. The Modified Quasi-Chemical Model: Part II. Multicomponent Solutions. Metall Trans A, 2001, 32, 1355 - 60.

[27] Chartrand P, Pelton AD. The Modified Quasi-Chemical Model: Part III. Two Sublattices. Metall Trans A, 2001, 32, 1397 - 407.

[28] Pelton AD, Chartrand P, Eriksson G. The Modified Quasi-Chemical Model : Part IV. TwoSublattice Quadruplet Approximation. Metall Trans A, 2001, 32, 1409 - 16.

[29] Teruel E, Cortés C, Díez LI, Arauzo I. Monitoring and prediction of fouling in coal-fired utility boilers using neural networks. Chem Eng Sci, 2005, 60, 5035 - 48.

[30] Bhadeshia HKDH. Neural networks in materials science. ISIJ Int, 1999, 39, 966 - 79. 
[31] Schulze FH, Salverda AP, Artificial Neural Networks in Integrated Water management Fiction or Future? (in Dutch). $\mathrm{H}_{2} \mathrm{O}, 1999$.

This Chapter is based on an earlier publication:

Stam AF, Livingston WR, Cremers MFG Brem G. Review of models and tools for slagging and fouling prediction for biomass co-combustion. IEA Bioenergy Task 32: Biomass Combustion and Cofiring, 2009. 

CO-FIRING WOOD OR MBM

\subsection{Introduction}

Ash deposition on superheater bundles is a well-known problem in coal-fired boilers. It is the main concern related to coal quality in the US [1]. Possible consequences are efficiency decrease, forced boiler downtime and increased corrosion rates when molten salts are formed on superheater surfaces. Ash deposition problems have occurred in coal-fired boilers co-firing biomass in The Netherlands. However, it is unknown whether these problems can (partly) be attributed to co-firing biomass. It is foreseen that biomass co-firing percentages will be increased in The Netherlands to comply with government $\mathrm{CO}_{2}$-emission goals. Hence, the lack of understanding the influence of co-firing biomass with coal on ash deposition introduces a risk.

The most used co-firing fuel in The Netherlands is wood, while a few plants use a mixture of MBM (Meat and Bone Meal) and biomass pellets. Little operating experience on co-firing of wood has been published. Results from pilot-scale test facilities and full scale tests vary: no change, increasing or decreasing problems [2, 3, 4]. An attempt to use standard fusibility correlations to evaluate the influence of co-firing wood on boiler slagging gave non-equivocal results [2]. So far, no results have been published on practical experience with co-firing MBM with coal in a pulverized fuel fired plant. Limited results have been published on modelling ash deposition for co-firing biomass with coal. These modelling results either focus on other fuels [5] and / or have a different modelling approach than in this current study $[5,6]$.

Concluding, there is a lack of understanding of the influence of co-firing biomass on ash deposition and a lack of (published) practical experience and modelling results. The objective of this study is therefore to explain and predict ash deposition at superheaters in coal-fired boiler co-firing biomass (biomass of interest is wood, and a mix of MBM and biomass pellets). To this end, both experimental and modelling work is performed. Full scale deposition tests using aircooled probes and microscopic analyses of the deposits are performed to get insight in the formation of the depositing phases and to explain mechanisms of deposit build-up. Emphasis is put on the influence of co-firing biomass compared to only coal firing. Thermodynamic modelling to predict the occurrence of molten phases is applied to explain the measured data. A prediction

model for ash deposition propensity is presented based on thermodynamic modelling; results for firing coal and co-firing biomass are presented. Experimental and modelling results (i.e. composition and build-up mechanisms) are compared to verify the suitability of thermodynamic calculations as a basis for prediction of ash deposition. 


\subsection{Experimental and modelling}

The experimental work presented in this chaper has taken place at Dutch coal-fired power plants Amer unit 9, and Maasvlakte unit 1. Tests with co-firing wood with coal ('test A9-1') and firing only coal ('test A9-2') have both been performed in Amer unit 9. This is a $640 \mathrm{MW}_{\mathrm{e}}$ pulverized coalfired boiler operated by RWE in The Netherlands. Over the last 10 years, roughly $15 \%$ of wood has been co-fired (co-firing rates in this chapter are based on of thermal heat input, unless stated otherwise). Ash deposition problems have been fairly modest in this boiler. A test where MBM and biomass pellets were co-fired ('test MV1-1') has been performed in Maasvlakte unit 1. This is a $531 \mathrm{MW}_{\mathrm{e}}$ pulverized coal-fired boiler operated by Uniper. Roughly, 6\% of MBM and biomass pellets have been co-fired over the last 10 years (on basis of thermal heat input). Ash deposition has been problematic, and superheater slagging was a regular cause of forced downtime. It is the operators' experience that superheater slagging is the most critical type of ash deposition. If heavy ash build-up at the most upstream superheaters is not removed in time, deposition can become uncontrollable and ash build-up will grow downstream with the possibility of clogged superheaters, resulting in a forced shut-down.

\subsubsection{Fuels and operating conditions}

Amer unit 9 is a supercritical, tangentially-fired, two-pass boiler. Dimensions of the first pass are approximately $17 \times 17 \times 74 \mathrm{~m}$. Residence time from the burners to the superheaters is approximately $3.5-4 \mathrm{sec}$ at full load. Wood is fired on the third burner layer, counted from below. The excess air factor $\lambda$ is 0.8 at the burners, except on the burner layer where biomass is fired where $\lambda$ is about 1.1. After the over fire air (OFA) ports, $\lambda$ is 1.16 which corresponds with $3 \%$ $\mathrm{O}_{2}$ in the flue gas (dry). Maasvlakte unit 1 is a subcritical, tangentially-fired, two-pass boiler. Dimensions of the first pass are approximately $14.6 \times 17.3 \times 60 \mathrm{~m}$ and residence time from the burners to the superheaters is approximately $1-2 \mathrm{sec}$ at full load. Biomass is fired with coal, either by injection into the pulverized fuel lines or by feeding to the coal belt supplying coal to the bunkers. $\lambda$ is 0.8 at the burners and 1.19 after the OFA ports corresponding with $3.5 \% \mathrm{O}_{2}$ in the flue gas (dry).

The average co-firing rate and fuel composition of the tests are given in Table 4.1. In all tests, the co-firing rate was somewhat higher during the night with lower load and vice versa during the day, as the boiler load is controlled with the coal flow. The co-firing rate and fuel composition has been fairly constant in the four week probe exposure test A9-1. The co-firing rate in the four weeks was $12.2 \%$ with a standard deviation of $1.5 \%$. Only coal was fired in the one week test A92. The composition of the coals fired in tests A9-1 and A9-2 are virtually identical. The co-firing rate in the $24 \mathrm{hr}$ test MV1-1 was $4 \%$. This combination of MBM and biomass pellets is abbreviated in this chapter as 'MBM-mix'. Biomass pellets are made from a mixture of wood, paper sludge, diatomaceous earth, composted municipal sewage sludge and coffee(grounds). 
Table 4.1 Ultimate, proximate and ash analysis of fuel blends (element concentrations in atom\%).

\begin{tabular}{lllllll}
\hline test & A9-1 & \multicolumn{3}{c}{ A9-2 } & MV1-1 & \\
\cline { 2 - 7 } & coal & wood & coal & coal & MBM & $\begin{array}{l}\text { biomass } \\
\text { pellets }\end{array}$ \\
\cline { 2 - 7 } firing rate (heat input, a.r.) & $87.8 \%$ & $12.2 \%$ & $100 \%$ & $96 \%$ & $3 \%$ & $1 \%$ \\
firing rate (mass basis, dry) & $84 \%$ & $16 \%$ & & $93.8 \%$ & $3.9 \%$ & $2.3 \%$ \\
\hline LHV (MJ/kg) & 24.8 & 18.2 & 24.8 & 24.1 & 17.7 & 10.1 \\
Moisture (a.r.) & $9.06 \%$ & $5.90 \%$ & $9.0 \%$ & $8.7 \%$ & $4.1 \%$ & $30.4 \%$ \\
Ash (a.r.) & $12.80 \%$ & $0.23 \%$ & $12.8 \%$ & $9.6 \%$ & $18.7 \%$ & $30.1 \%$ \\
Volatiles (a.r.) & $28.77 \%$ & $79.96 \%$ & $28.8 \%$ & & $70.3 \%$ & $54.1 \%$ \\
Cl (a.r.) & $0.02 \%$ & $0.01 \%$ & $0.02 \%$ & $0.02 \%$ & $0.58 \%$ & $0.11 \%$ \\
C (d.a.f.) & $71.05 \%$ & $51.67 \%$ & $70.95 \%$ & $61.3 \%$ & $45.1 \%$ & $35.1 \%$ \\
H (d.a.f.) & $4.55 \%$ & $6.14 \%$ & $4.54 \%$ & $4.3 \%$ & $6.1 \%$ & $4.6 \%$ \\
N (d.a.f.) & $1.65 \%$ & $0.18 \%$ & $1.65 \%$ & $1.3 \%$ & $8.8 \%$ & $1.1 \%$ \\
S (d.a.f.) & $0.79 \%$ & $0.01 \%$ & $0.79 \%$ & $0.74 \%$ & $0.5 \%$ & $0.3 \%$ \\
Si (a.r.) & $3.21 \%$ & $0.02 \%$ & $3.27 \%$ & $2.75 \%$ & $0.11 \%$ & $6.66 \%$ \\
Al (a.r.) & $1.72 \%$ & $0.004 \%$ & $1.40 \%$ & $1.10 \%$ & $0.02 \%$ & $2.00 \%$ \\
Fe (a.r.) & $0.51 \%$ & $0.003 \%$ & $0.76 \%$ & $0.49 \%$ & $0.17 \%$ & $1.38 \%$ \\
Ca (a.r.) & $0.56 \%$ & $0.05 \%$ & $0.41 \%$ & $0.18 \%$ & $5.67 \%$ & $1.72 \%$ \\
Mg (a.r.) & $0.12 \%$ & $0.008 \%$ & $0.15 \%$ & $0.08 \%$ & $0.11 \%$ & $0.46 \%$ \\
Na (a.r.) & $0.05 \%$ & $0.004 \%$ & $0.19 \%$ & $0.06 \%$ & $0.46 \%$ & $0.13 \%$ \\
K (a.r.) & $0.11 \%$ & $0.03 \%$ & $0.18 \%$ & $0.17 \%$ & $0.71 \%$ & $0.46 \%$ \\
Ti (a.r.) & $0.10 \%$ & $0.001 \%$ & $0.07 \%$ & $0.06 \%$ & $0.00 \%$ & $0.05 \%$ \\
P (a.r.) & $0.09 \%$ & $0.007 \%$ & $0.03 \%$ & $0.01 \%$ & $2.69 \%$ & $1.02 \%$ \\
S (a.r.) & $0.63 \%$ & $0.01 \%$ & $0.16 \%$ & $0.60 \%$ & $0.39 \%$ & $0.12 \%$ \\
\hline & & & & & &
\end{tabular}

When co-firing $12.2 \%$ wood, the contribution of wood to the total amount of ash fed to the boiler is with $0.34 \%$ (on a.r. basis) relatively low. The ash content of the coal is more than a factor of 50 higher than that of the wood. Nonetheless, $\mathrm{Cl}$ and $\mathrm{K}$ concentrations in wood are only a factor of 1.6 and 3.4 lower, respectively. Si and $\mathrm{Al}$ are the main inorganic components in coal, while in wood these are $\mathrm{Ca}$ and $\mathrm{K}$. When co-firing $4 \% \mathrm{MBM}-\mathrm{mix}$, the contribution of MBM-mix to the total ash is relatively high with $14.3 \%$ (on a.r. basis). The ash content in MBM and biomass pellets is a factor of respectively 2 and 3 higher than that of the coal. The $P$ content is a factor of 270 and 100 higher, the Ca content a factor of 32 and 10 higher, and the $\mathrm{Cl}$ content a factor of 29 and 5.5, respectively. 


\subsubsection{Air Cooled Probe Set-up}

In all tests, an air-cooled probe was used to collect deposit samples. The set-up of the probe is shown in Figure 4.1. The probe protrudes the boiler wall for about $1.5 \mathrm{~m}$ through a specially made hatch at a location chosen in such a way that the probe tip is located close $(<1 \mathrm{~m})$ to the superheater bundle. Two probe trials were performed subsequently in tests A9-1 and A9-2 at the same location just below the bundles at the 'nose' of the boiler. In the MV1-1 test, two probes were exposed at the same time at two locations where the flue gases meet the bundles. Drawings of the Amer and Maasvlakte boilers with the location of the probes are given in Appendix 4.A. The tip of the probe holds detachable fouling rings with an outer diameter of 38 $\mathrm{mm}$. The temperature of the fouling rings is continuously controlled with cooling air. Two thermocouples are located at different known distances from the metal surface at the inside of the rings. From this, the surface temperature is calculated by extrapolation. This calculated surface temperature is input for a PID-controller that operates a control valve for the cooling air. The temperature in tests A9-1 and A9-2 was set to $680^{\circ} \mathrm{C}$ which mimics the surface temperature of a reheater operating at a steam temperature of $620^{\circ} \mathrm{C}$. This reflects the situation where wood is co-fired in a high-efficient coal-fired boiler, i.e. the most likely future market situation of coalfired boilers in The Netherlands. In test MV1-1, the metal temperature was set at $590^{\circ} \mathrm{C}$, which corresponds to a steam temperature of about $540{ }^{\circ} \mathrm{C}$. This situation reflects realistic conditions at the time of measurement for a conventional Dutch coal-fired boiler. Based on design data, the gas temperature around the probe is approximately $1,300{ }^{\circ} \mathrm{C}$.

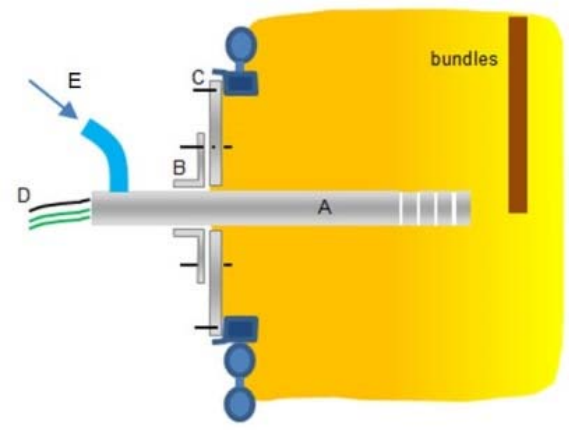

Figure 4.1 Schematic of probe. A) Probe (sensors are located at the tip, exposed in the boiler). B) Flange for mounting the probe. C) Insert plate, mounted on an inspection hatch to which the flange is bolted. D) Thermocouples and electrodes. E) Compressed air supply.

\subsubsection{Samples, preparation and microscopic investigations}

Two rings with deposits were retrieved after each testing period. The complete ring assembly after the second testing period is shown in Figure 4.2, left. The samples were vacuum imbedded 
in slow curing epoxy resin. To preserve water soluble compounds, cross sections were made by grinding and polishing with water free mediums. Prepared rings are shown in Figure 4.2, right.

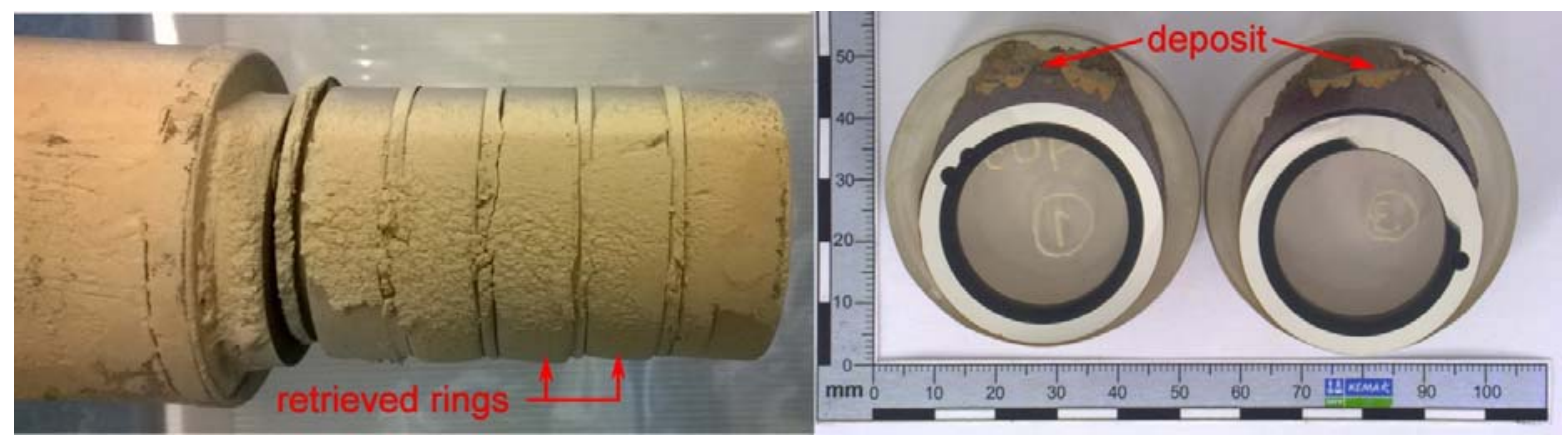

Figure 4.2 Superheater probe rings with deposit. Left: probe tip after exposure (test A9-2). Right: prepared rings with deposit on top (test A9-1).

Carbon was deposited on the sample surface to overcome charging during SEM investigations. Backscattered electron (BE) images and secondary electron (SE) images were produced and the composition was analysed on micro-scale level with EDS (Energy Dispersive X-ray Spectroscopy). In addition, KEMPhase images were made. KEMPhase is an in-house developed tool which enables the results of element mappings to be presented as false colour representations that show the distribution of predefined phases.

\subsubsection{Thermodynamic equilibrium calculations}

The computer programme FactSage (see [7] for a general description) has been used to calculate thermodynamic equilibrium. FactSage includes an extensive component and solution database. Limitations of thermodynamic equilibrium calculations in order to simulate the behaviour of inorganic elements during combustion have been reviewed by [8]. The residence time of particles in the boiler is in the order of seconds, and the maximum temperature that is reached is about $1,700{ }^{\circ} \mathrm{C}$ [9]. It is expected that especially the larger particles will not (completely) reach the equilibrium state during combustion, and kinetic limitations play an important role. Also the mode of occurrence of elements in the fuel, temperature gradients, concentration gradients and physical processes like adsorption are not taken into account. These drawbacks can be accounted for, as described by [8]. For example, by selection of the database components that can be expected based on practical experience, kinetic constraints can partly be taken into account (see Appendix 4.B for the list of selected compounds).

The mode of occurrence of elements in the fuel determines if an element behaves inert (i.e. 'not available for reaction') or is reactive (i.e. 'available for reaction'). The availability for reaction of inorganic elements in coal is based on the comparison of the mineral composition of coal ash 
and fly ash. When comparing this coal ash and fly ash mineral compositions, it appears that some minerals (partly) transformed (i.e. a lower concentration of the mineral in the fly ash than in the coal ash) during combustion while other minerals are formed (i.e. a higher concentration of the mineral in the fly ash than in the coal ash). The change per mineral is calculated using the dataset of [10]. The availability of main elements in coal is derived based on these mineral changes, see Table 4.2. A more detailed description of deriving element availability is given in Appendix 4.C. The available fraction (availability multiplied by element concentration in the fuel) is input for the equilibrium calculations.

Table 4.2 Calculated element availabilities.

\begin{tabular}{lllll}
\hline Element & $\begin{array}{l}\text { Availability } \\
\text { (coal) }\end{array}$ & $\begin{array}{l}\text { Availability } \\
\text { (wood) }\end{array}$ & $\begin{array}{l}\text { Availability } \\
\text { (MBM) }\end{array}$ & $\begin{array}{l}\text { Availability } \\
\text { (biomass } \\
\text { pellets) }\end{array}$ \\
\hline $\mathrm{Si}$ & $58 \%$ & $58 \%$ & $59 \%$ & $58 \%$ \\
$\mathrm{Al}$ & $63 \%$ & $63 \%$ & $63 \%$ & $63 \%$ \\
$\mathrm{Fe}$ & $66 \%$ & $66 \%$ & $66 \%$ & $66 \%$ \\
$\mathrm{Ca}$ & $59 \%$ & $68 \%$ & $61 \%$ & $69 \%$ \\
$\mathrm{Mg}$ & $69 \%$ & $87 \%$ & $75 \%$ & $74 \%$ \\
$\mathrm{Na}$ & $68 \%$ & $100 \%$ & $100 \%$ & $91 \%$ \\
$\mathrm{~K}$ & $62 \%$ & $100 \%$ & $100 \%$ & $79 \%$ \\
$\mathrm{Ti}$ & $69 \%$ & $69 \%$ & $69 \%$ & $69 \%$ \\
$\mathrm{P}$ & $69 \%$ & $69 \%$ & $69 \%$ & $69 \%$ \\
$\mathrm{~S}$ & $45 \%$ & $91 \%$ & $91 \%$ & $98 \%$ \\
$\mathrm{Cl}$ & $69 \%$ & $100 \%$ & $100 \%$ & $100 \%$ \\
\hline
\end{tabular}

Often, biomass is characterized with chemical fractionation (CF) and the elements in the fuel are regarded available for reaction to the extent that they are soluble in water or ammonium acetate solution [11]. This available fraction is interpreted as being water soluble salts and organically bound elements. The remainder, soluble in an $\mathrm{HCl}$ solution or non-soluble, is considered to consist of nonreactive minerals, and is not taken into account in the equilibrium calculations. Our approach differs from the approach taken by [11] who applied the method for fluidized bed combustion. With pulverized fuel combustion, maximum flue gas temperatures are much higher than with fluidized bed combustion (approximately $1,700{ }^{\circ} \mathrm{C}$ compared to $900{ }^{\circ} \mathrm{C}$ ). We therefore assume, in case of pulverized fuel combustion, that minerals in biomass are at least as available as the minerals in coal. Hence, for biomass the maximum of the availabilities of an element derived for coal and of the CF-results are taken. The CF results have been obtained from [12]; the calculated availabilities are presented in Table 4.2. 


\subsubsection{Prediction of deposition propensity}

It is assumed that the bulk of the superheater deposits are formed by inertial impaction. The deposition rate by inertial impaction of larger particles is determined by the mass flow of particles, the chance of impacting and the probability of sticking. When assuming that the chance of impaction does not change, a deposit measure defined by the mass of molten ash multiplied by the sticking probability $\left(m_{\text {molten ash }}{ }^{*} P_{\text {stick }}\right)$ can be used to compare the effect of different fuel blends. The amount of molten ash is calculated using thermodynamic equilibrium. Molten ash is slag and molten Fe-O-S.

The sticking probability of an impacting molten slag particle is, in case of a non-sticky surface, related to its viscosity [13]. The sticking probability is 1 when the viscosity $\mu$ is below the reference viscosity. If the viscosity is above the reference viscosity, the sticking probability is

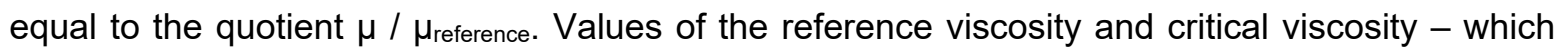
both mark the viscosity at and below which $P_{\text {stick }}=1$ - that are found in literature lie between 1 and $1 \cdot 10^{9} \mathrm{~Pa}$.s. Therefore, an average value for $\mu_{\text {reference }}$ of $1 \cdot 10^{5} \mathrm{~Pa}$.s is applied in this chapter. The Urbain viscosity model is used to calculate the slag viscosity at a given temperature and a certain slag composition. The slag composition is calculated using thermodynamic equilibrium as a function of temperature. The Urbain model allows for discriminating between $\mathrm{Fe}^{2+}$ and $\mathrm{Fe}^{3+} ; \mathrm{Fe}$ will be present in the slag as $\mathrm{Fe}^{2+}$ under reducing conditions and as $\mathrm{Fe}^{3+}$ under oxidizing conditions [14].

Thermodynamically, Fe in slag is more stable than a Fe-O-S melt and only Fe in slag is stable with an equilibrium calculation where a slag phase is included. Since it is known that in practice a Fe-O-S melt is formed under reducing conditions by pyrite that is not associated with slagforming compounds $[15,16]$, two separate calculations are made: one where a slag is included, and one without slag but with Fe-O-S melt. For demonstration purposes, it is assumed that $50 \%$ of the available Fe in coal will be associated with glass forming compounds and the remainder as (liberated) pyrite. This assumption is based on Helbe et al. (1990) [17] who found with CCSEM that $40-60 \%$ of $\mathrm{Fe}$ is associated with glassy ash particles. It is assumed that no pyrite is present in biomass. The sticking probability of Fe-O-S melt is assumed to be equal to 1 as [16] demonstrated nearly $100 \%$ particle adhesion efficiency when a molten iron oxysulphide phase was predicted to occur.

\subsection{Results}

In this section the results of the microscopic analysis of full-scale deposition probe tests (deposit lay-out and (general) composition, identified phases in deposits) and thermodynamic modelling are presented. Also, a comparison between the compositions of the slag as determined by SEManalysis of experimentally obtained deposits and thermodynamic modelling is made. 


\subsubsection{Microscopy and chemical analysis of probe test deposits}

\subsubsection{Deposit lay-out and composition}

The results of the microscopic investigations for test A9-1 (firing coal and wood) are shown in Figure 4.3. The results of tests A9-2 (coal) and MV1-1 (coal and MBM-mix) as well as a summary of the observations are presented in Appendix 4.E. The upstream "coal-deposit" is flat and nonporous while the "coal/wood-deposit" and "coal/MBM-mix-deposit" are thicker, wedge-shaped and porosity varies per location in the deposit.

The deposits consist largely of Fe, Si and Al. The Fe concentration is highest in the "coaldeposit" $(20 \%)$ while the concentration of $(\mathrm{Si}+\mathrm{Al})$ is highest in the "coal/wood-deposit" and "coal/MBM-mix-deposit" (respectively 20 and 15\%). In addition, the concentration of $(\mathrm{Ca}+\mathrm{P})$ is highest in "coal/MBM-mix-deposit": $9 \%$ versus $3 \%$ in the other deposits. The initial upstream deposits (approximately the first $500 \mu \mathrm{m}$ ) contain larger particles (typical diameter $50-75 \mu \mathrm{m}$ and ranging up to approximately $250 \mu \mathrm{m}$ ). Downstream deposits are porous and consist of small particles (typically $<10 \mu \mathrm{m}$ ), rich in Si and Al.

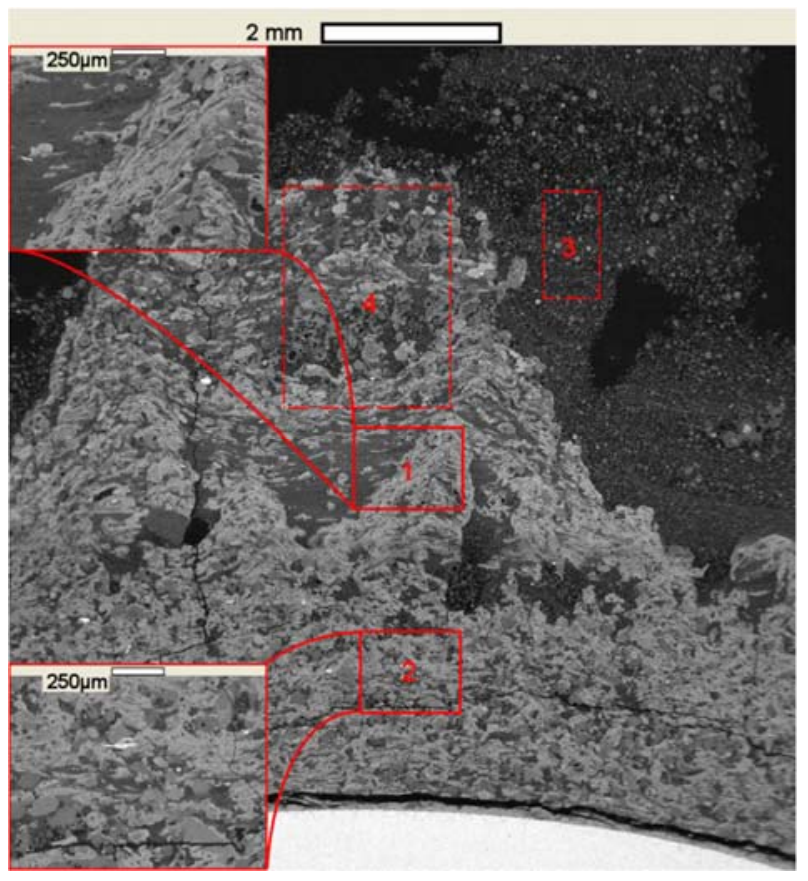

Figure 4.3 Upstream deposit of coal and wood firing, ('test A9-1'); back scatter image. Details show Fe-rich larger particles (e.g. detail 2) or smaller, Al and Si-rich particles (e.g. details 3 and 4). Element concentrations: 1) $9 \% \mathrm{Al}, 10 \% \mathrm{Si}, 3 \% \mathrm{Ca}, 11 \% \mathrm{Fe}$; 2) $6 \% \mathrm{Al}$, $9 \% \mathrm{Si}, 3 \% \mathrm{Ca}, 15 \% \mathrm{Fe}$; 3 ) $8 \% \mathrm{Al}, 13 \% \mathrm{Si}, 1 \% \mathrm{Ca}, 15 \% \mathrm{Fe}$; 4$) 8 \% \mathrm{Al}, 13 \% \mathrm{Si}, 5 \% \mathrm{Ca}$, $7 \% \mathrm{Fe}$. 


\subsubsection{Identified phases in deposits}

Various phases have been identified in the deposits. Frequently observed phases are categorized according to Table 4.3. Discrimination between phases has mainly been done based on elemental composition, but also on shape and size of particles. The rationale is that the different identified phases stem from different minerals in the fuel, behave chemically and/or physically different during their trajectory from burner to superheater, deposit by a different mechanism or react differently after deposition. The origin, chemical reactions and deposition mechanisms of the different phases are discussed in section 4.4.

A phase designated as category 1 includes $\mathrm{O}, \mathrm{Al}$ and Si-rich particles. They are either spherical and contain other elements like $\mathrm{Fe}, \mathrm{Ca}, \mathrm{P}$ (category $1 \mathrm{a}$ ), or they are arbitrarily shaped, porous particles with very low concentrations of elements other than Al, Si and O (category $1 \mathrm{~b}$ ). Particles of the latter category occur in the outer side of the deposit. Category 2 phase is $\mathrm{O}$ and Fe-rich, and contains varying concentrations of $\mathrm{Al}$ and $\mathrm{Si}$. This category is sub-divided into one including particles that contain $S$ (category $2 a$ ) and one including particles that do not contain $S$ (category $2 \mathrm{~b}$ ). Category 3 phase is $\mathrm{O}$ and Si-rich, and particles are arbitrarily shaped. Category 4 phase is rich in $\mathrm{O}$ and $\mathrm{Ca}$, and is subdivided in a category of discrete particles containing also $\mathrm{C}$ (category $4 a$ ), and a category where individual particles cannot be discriminated and particles are rich in $\mathrm{Ca}, \mathrm{S}, \mathrm{O}, \mathrm{Al}$ and $\mathrm{Si}$ (category 4b). Particles of category $4 \mathrm{a}$ are only found as initial deposit after 1 week of coal firing. Examples of the different phases as identified in Back scatter Electron (BE) images are given in following sections.

Table 4.3 Categories of particles in the deposit.

\begin{tabular}{|c|c|c|c|c|c|c|c|c|}
\hline $\begin{array}{l}\text { category } \\
\mathrm{nr}\end{array}$ & abundance & main elements & size & shape & $\begin{array}{l}\text { location in } \\
\text { deposit }\end{array}$ & $\begin{array}{l}\text { A9- } \\
2^{*}\end{array}$ & $\begin{array}{l}\text { A9- } \\
1 *\end{array}$ & $\begin{array}{l}\text { MV1- } \\
1^{*}\end{array}$ \\
\hline $1 a$ & major & $\mathrm{Al}, \mathrm{Si}, \mathrm{Ca}, \mathrm{P}, \mathrm{O}$ & $\begin{array}{l}<1-250 \\
\mu \mathrm{m}\end{array}$ & spherical & everywhere & $y$ & $y$ & $y$ \\
\hline $1 b$ & minor & Al, Si, O & $<250 \mu \mathrm{m}$ & arbitrary & outer side & $y$ & $y$ & $y$ \\
\hline $2 a$ & major & $\mathrm{Fe}, \mathrm{O}, \mathrm{Al}, \mathrm{Si}, \mathrm{S}$ & $>100 \mu \mathrm{m}$ & elliptical & everywhere & $y$ & $n$ & $y$ \\
\hline $2 b$ & major & $\mathrm{Fe}, \mathrm{O}, \mathrm{Al}, \mathrm{Si}$ & $\begin{array}{l}\text { few } \mu \mathrm{m}- \\
250 \mu \mathrm{m}\end{array}$ & $\begin{array}{l}\text { spherical } \\
\text { or flat }\end{array}$ & $\begin{array}{l}\text { flat: bulk } \\
\text { spherical: } \\
\text { outside }\end{array}$ & $y$ & $y$ & $y$ \\
\hline 3 & minor & $\mathrm{Si}, \mathrm{O}$ & $<150 \mu \mathrm{m}$ & arbitrary & everywhere & $y$ & $y$ & $y$ \\
\hline $4 a$ & minor & $\mathrm{Ca}, \mathrm{C}, \mathrm{O}$ & $\begin{array}{l}\text { submicron } \\
\text { - few } \mu \mathrm{m}\end{array}$ & arbitrary & $\begin{array}{l}\text { initial } \\
\text { deposit }\end{array}$ & $y$ & $n$ & $\mathrm{n}$ \\
\hline $4 b$ & minor & $\mathrm{Ca}, \mathrm{S}, \mathrm{O}, \mathrm{Al}, \mathrm{Si}$ & $\begin{array}{l}\text { areas } \\
<250 \mu \mathrm{m}\end{array}$ & arbitrary & $\begin{array}{l}\text { initial } \\
\text { deposit }\end{array}$ & $y$ & $y$ & $\mathrm{n}$ \\
\hline
\end{tabular}

* "y" means phase identified, "n" means phase not identified 
Al and Si-rich particles

Category 1a

Spherical particles, rich in $\mathrm{Al}$ and $\mathrm{Si}$ are designated as category 1a particles. They occur in different sizes and element concentrations vary. Typical compositions of these particles are determined by performing SEM-EDX measurements at an area with multiple spherical particles with similar grey pattern in the back scatter image. The typical composition is $24-28 \%(\mathrm{Al}+\mathrm{Si})$, $2-4 \% \mathrm{Ca}$, and $1-2 \% \mathrm{Fe}$; details are supplied in Table 4.4 for the different tests. Element concentrations can be as high as $24 \% \mathrm{Ca}, 6 \% \mathrm{Mg}, 4 \%(\mathrm{Na}+\mathrm{K})$, and $13 \% \mathrm{P}$. Smaller $(<2 \mu \mathrm{m})$, mainly spherical particles typically contain $27-32 \%(\mathrm{Al}+\mathrm{Si}), 1-4 \% \mathrm{Ca}$, and $0-1 \% \mathrm{Fe}$. An example of a collection of these smaller (in this case sintered) particles, is shown in Figure 4.4. An example of particles, rich in $\mathrm{Ca}$ and $\mathrm{P}$ is shown in Figure 4.5 (light-green colour). Particles rich in $\mathrm{Ca}$ and $\mathrm{P}$ that also contain varying concentrations of $\mathrm{Al}$ and $\mathrm{Si}$ are present more frequently in deposits from test MV1-1, than in other tests. The particles have a diameter of roughly $40-150$ $\mu \mathrm{m}$. The $(\mathrm{Al}+\mathrm{Si})$ concentration in $\mathrm{Ca}$ and $\mathrm{P}$-rich particles can be as low as $(\mathrm{Al}+\mathrm{Si})=2.4 \%$ while concentrations of $\mathrm{P}$ and $\mathrm{Ca}$ being $13 \%$ and $21 \%$, respectively.

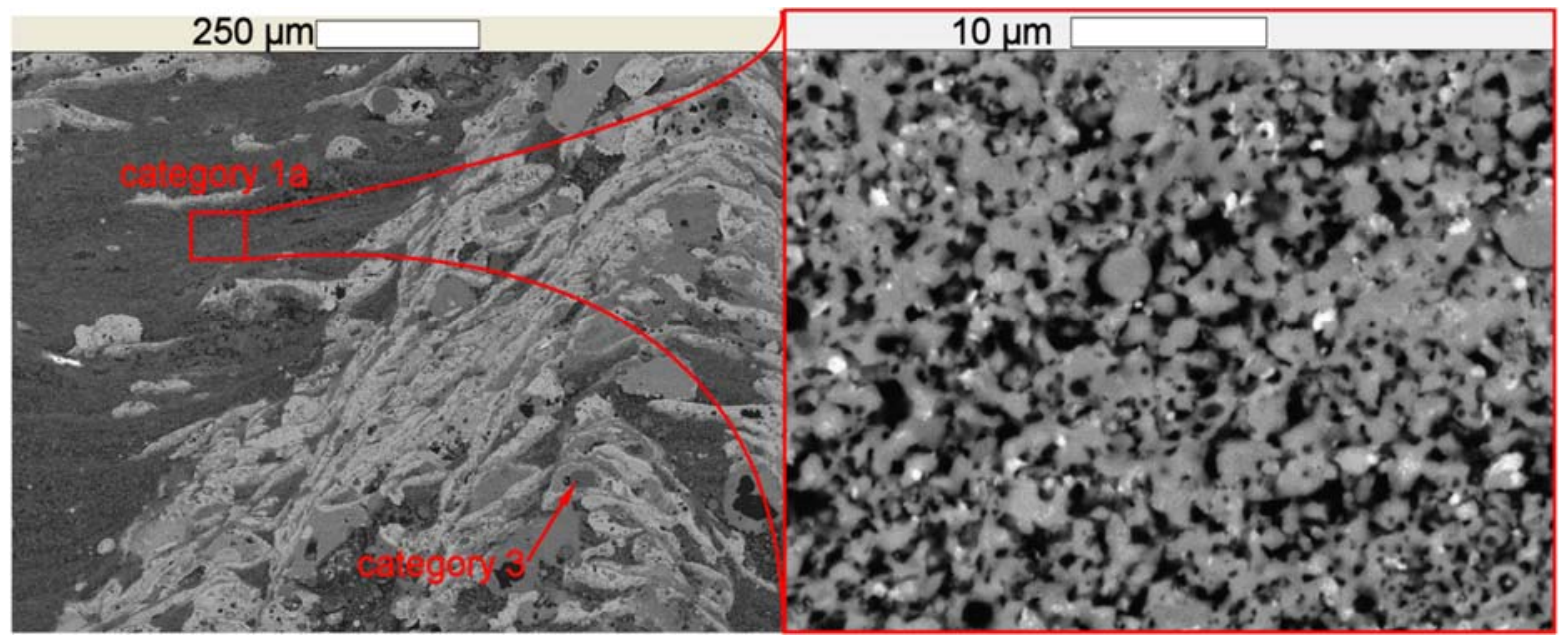

Figure 4.4 Left: superheater probe deposit co-firing wood with coal (test A9-1), middle of deposit; BE image. Particles of categories $1 \mathrm{a}$ and 3 indicated. Right: enlargement of red square showing sintered spherical aluminosilicate particles with diameter $<2 \mu \mathrm{m}$ (category 1a). 


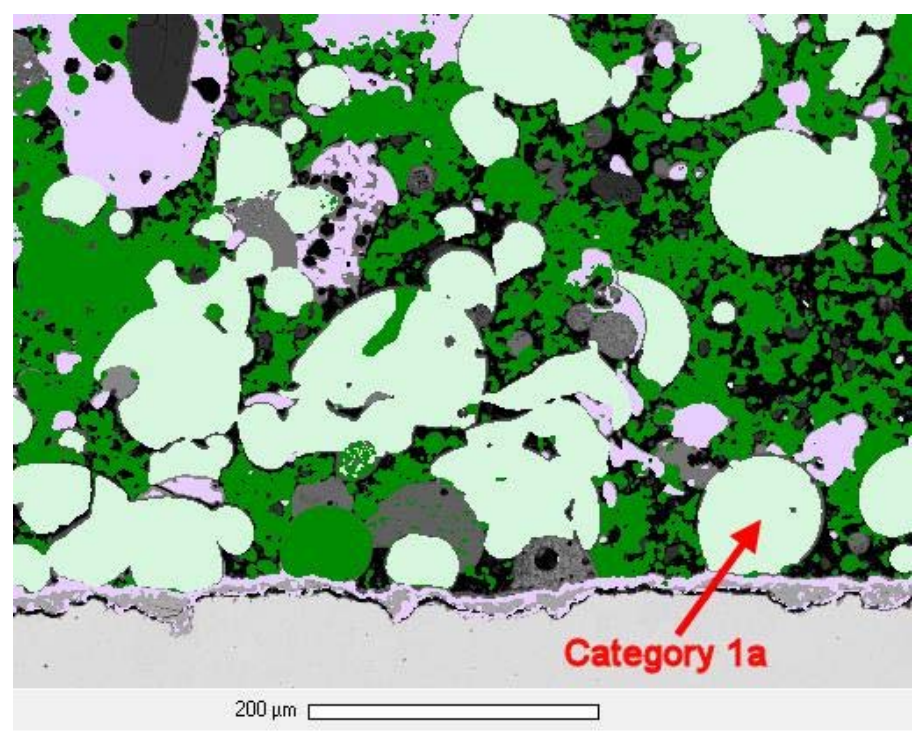

Figure 4.5 Superheater probe deposit co-firing MBM-mix with coal (test MV1-1). BE image with an overlay of identified phases: dark-green = rich in $\mathrm{Al}$ and $\mathrm{Si}$, light-green = rich in $\mathrm{Ca}$ and $\mathrm{P}$, purple $=$ rich in Fe. Larger spherical aluminosilicate particle rich in $\mathrm{Ca}$ and $\mathrm{P}$ (category $1 \mathrm{a}$ ) is indicated.

\section{Category $1 \mathrm{~b}$}

Particles in category $1 \mathrm{~b}$ are $\mathrm{Al}$ and Si-rich, are porous and are arbitrarily shaped with a diameter varying between a few $\mu \mathrm{m}$ to $>25 \mu \mathrm{m}$. Their typical composition is $15-17 \% \mathrm{Al}, 15-17 \% \mathrm{Si}$ and $65-67 \%$ O. A BS-image showing examples of such particles is shown in Appendix 4.E. The particles are present at the outer surface of the deposit (i.e. last deposited).

Fe-rich particles

\section{Category $2 a$}

Particles rich in $\mathrm{Fe}, \mathrm{S}, \mathrm{O}, \mathrm{Al}$ and $\mathrm{Si}$ occur only in the deposit from the 1 week coal firing test. The particles have a diameter of $>100 \mu \mathrm{m}$ and have an elliptical shape. Figure 4.6 (left) shows that part of the particle has crystallized. The crystallized part of the particle contains mainly $\mathrm{Fe}$ (typically $35-50 \%$ ) and $\mathrm{O}$, and does not contain S. S concentrations in the non-crystallized part, however, are up to $25 \%$, and the Fe concentration is $10-20 \%$; typical concentration of Al, Si and Ca are $4-8 \%, 8-14 \%$ and $2-5 \%$, respectively. A 1 - $10 \mu \mathrm{m}$ thick layer is observed at the outer surface of the particle which has a composition similar to that of the crystals. 

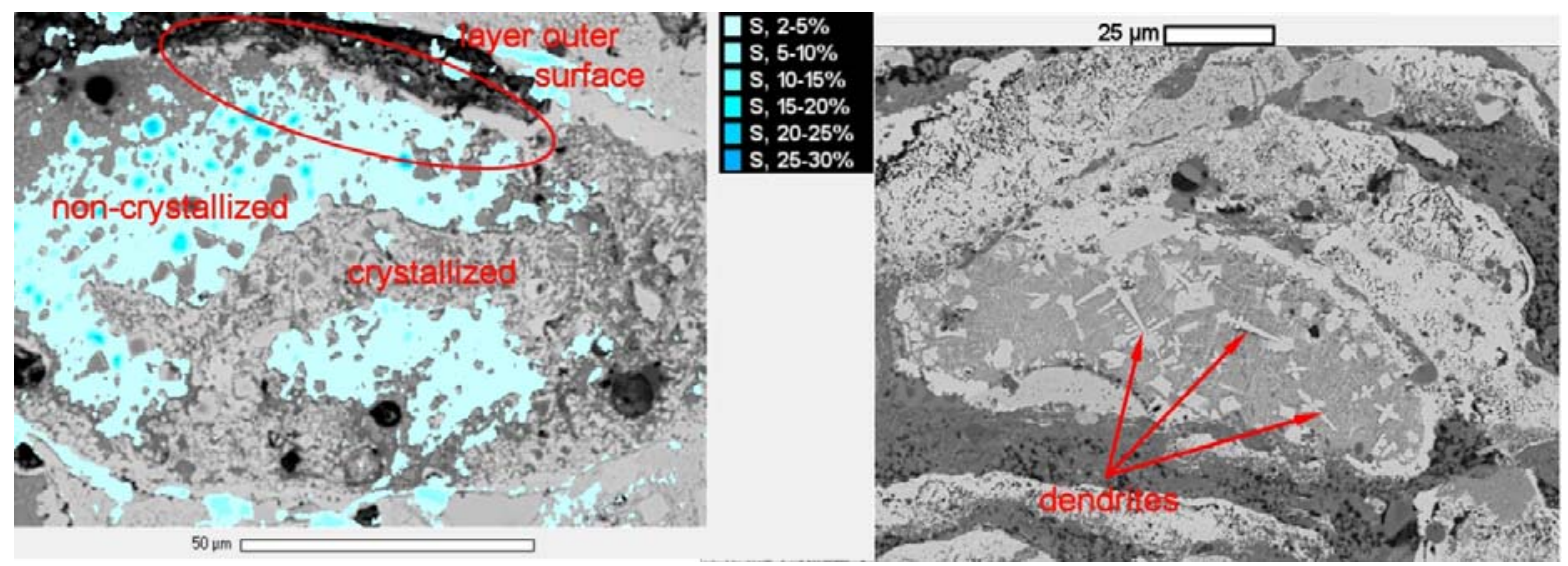

Figure 4.6 Superheater probe deposit coal firing (test A9-2), upstream deposit; BE images. Left: Category 2a Fe-rich particle with an overlay indication the S-concentration (atomic \%). Right: Category 2b Fe-rich particle with dendrite crystal growth.

\section{Category $2 b$}

A typical example of a collection of Fe-rich particles is shown in Figure 4.3. This shows that these particles make up for a large part of the deposit of the 4 week testing period firing coal and wood. The Fe-rich particles in the bulk of the deposit are flat-shaped while small, spherical particles (diameter $<20 \mu \mathrm{m}$ ) are situated at the outer deposit. Fe-rich particles typically contain $17-38 \%$ $\mathrm{Fe}, 60-64 \% \mathrm{O}$, and $0-18 \%$ ( $\mathrm{Al}+\mathrm{Si}$ ). Figure 4.6 (right) shows a flat-shaped Fe-rich category $2 \mathrm{~b}$ particle which has partly crystallized and crystals grow as dendrites. The dendrites have a higher concentration of $\mathrm{Fe}$ and a lower concentration of $\mathrm{Al}$ and $\mathrm{Si}$ compared to their surrounding area. Crystals are sub-micron when the $\mathrm{Al}$ and $\mathrm{Si}$ content in a particle is low (Al + $\mathrm{Si}<5 \%)$. A 1 $10 \mu \mathrm{m}$ thick layer is observed at the outer surface of the particle which has a composition similar to that of the crystals.

Si-rich particles

\section{Category 3}

Particles that typically contain $30 \% \mathrm{Si}$ and $69 \% \mathrm{O}$ are arbitrarily shaped and are up to about 150 $\mu \mathrm{m}$ in size. These particles are situated throughout the deposit. An example is shown in Figure 4.4 .

\section{Ca-rich particles}

\section{Category $4 a$}

Particles of category $4 a$ are arbitrarily shaped with a diameter in the range of submicron to several micrometres. Typically, the particles contain $19 \% \mathrm{Ca}$ and $\mathrm{C}$ (Ca to $\mathrm{C}$ ratio is close to 1 ) and $59 \%$ O. An example is shown in Appendix 4.E. The particles are observed in the 
downstream deposit from the 1 week coal firing test (A9-2). These particles have not been observed in the MV1-1 test.

\section{Category $4 \mathrm{~b}$}

In initial deposits on the surface of the exposure rings, areas are observed rich in $\mathrm{Ca}, \mathrm{S}$ and $\mathrm{O}$. No individual particles can be recognised / distinguished. The main elements that are present are $\mathrm{Ca}(5-16 \%)$, S $(1-16 \%), \mathrm{O}(64-71 \%)$, Al and Si $(0-26 \% \mathrm{Al}+\mathrm{Si})$. Typically, there are two mixed phases, a phase with more $(\mathrm{Al}+\mathrm{Si})$ and less $(\mathrm{Ca}+\mathrm{S})$, and vice versa. An example is shown in Appendix 4.E. These areas have not been observed in the deposits of the MV1-1 test.

\subsubsection{Thermodynamic calculation results}

The phases that are thermodynamically stable and the temperature region in which they are stable have been calculated with FactSage. The results are very comparable for firing coal and co-firing coal with wood or MBM-mix. The main phases that are stable under oxidizing and reducing conditions are shown in Table 4.4. These phases are presented in comparison with the main phases as identified with SEM in the previous section. A Fe-O-S melt is present when the slag phase and iron oxides are left out of the calculations. Detailed results of the calculations (coal and biomass co-firing) are supplied in Appendix 4.F. Also, an overview showing the temperature region at which compounds or liquid solutions are stable is given in Appendix 4.F. The equilibrium composition of the slag is shown for both $1700{ }^{\circ} \mathrm{C}$ (maximum flue gas temperature in boiler) and $1,300{ }^{\circ} \mathrm{C}$ (approximate flue gas temperature at superheaters) in Table 4.5 .

Table 4.4 Main phases in deposit as determined with SEM and main phases as calculated with FactSage containing the same major elements as in phases.

\begin{tabular}{lll}
\hline Category (main elements) & Equilibrium (oxidizing) & Equilibrium (reducing) \\
\hline $1 \mathrm{a}(\mathrm{Al}, \mathrm{Si}, \mathrm{Ca}, \mathrm{P}, \mathrm{O})$ & slag & slag \\
1b $(\mathrm{Al}, \mathrm{Si}, \mathrm{O})$ & mullite $\left(\mathrm{Al}_{6} \mathrm{Si}_{2} \mathrm{O}_{13}(\mathrm{~s})\right)$ & mullite $\left(\mathrm{Al}_{6} \mathrm{Si}_{2} \mathrm{O}_{13}(\mathrm{~s})\right)$ \\
$2 \mathrm{a}(\mathrm{Fe}, \mathrm{O}, \mathrm{Al}, \mathrm{Si}, \mathrm{S})$ & & $\mathrm{Fe}-\mathrm{O}-\mathrm{S}$ \\
$2 \mathrm{~b}(\mathrm{Fe}, \mathrm{O}, \mathrm{Al}, \mathrm{Si})$ & $\mathrm{Fe}_{2} \mathrm{O}_{3}(\mathrm{~s})$ & \\
$3(\mathrm{Si}, \mathrm{O})$ & tridymite $\left(\mathrm{SiO}_{2}(\mathrm{~s})\right)$ & tridymite $\left(\mathrm{SiO}_{2}(\mathrm{~s})\right)$ \\
$4 \mathrm{a}(\mathrm{Ca}, \mathrm{C}, \mathrm{O})$ & $\mathrm{Ca}_{3}\left(\mathrm{PO}_{4}\right)_{2}(\mathrm{~s})$ & \\
$4 \mathrm{~b}(\mathrm{Ca}, \mathrm{S}, \mathrm{O}, \mathrm{Al}, \mathrm{Si})$ & $\mathrm{Ca}_{3}\left(\mathrm{PO}_{4}\right)_{2}(\mathrm{~s})$ & \\
\hline
\end{tabular}


Table 4.5 Typical slag composition as determined with SEM-EDX and equilibrium composition of slag at 1,300 and $1,700{ }^{\circ} \mathrm{C}$.

\begin{tabular}{llllllllll}
\hline & coal firing & \multicolumn{7}{c}{ co-firing wood } & \multicolumn{5}{c}{ co-firing MBM-mix } \\
& SEM- & equilibrium & equilibrium & \multicolumn{3}{c}{ equilibrium } & equilibrium & \multicolumn{3}{c}{ equilibrium } & equilibrium \\
& EDX & $1,300^{\circ} \mathrm{C}$ & $1,700^{\circ} \mathrm{C}$ & SEM-EDX & $1,300^{\circ} \mathrm{C}$ & $1,700^{\circ} \mathrm{C}$ & SEM-EDX & $1,300^{\circ} \mathrm{C}$ & $1,700^{\circ} \mathrm{C}$ \\
\hline $\mathrm{O}$ & $66.4 \%$ & $62.0 \%$ & $61.9 \%$ & $66.0 \%$ & $62.1 \%$ & $62.2 \%$ & $65.1 \%$ & $62.6 \%$ & $62.6 \%$ \\
$\mathrm{Na}$ & $0.7 \%$ & $1.8 \%$ & $1.6 \%$ & $0.6 \%$ & $0.6 \%$ & $0.5 \%$ & $1.0 \%$ & $1.1 \%$ & $1.0 \%$ \\
$\mathrm{Mg}$ & $0.7 \%$ & $1.3 \%$ & $1.2 \%$ & $0.9 \%$ & $1.1 \%$ & $0.9 \%$ & $0.9 \%$ & $1.1 \%$ & $1.0 \%$ \\
$\mathrm{Al}$ & $11.3 \%$ & $9.0 \%$ & $9.7 \%$ & $12.1 \%$ & $8.0 \%$ & $11.6 \%$ & $8.6 \%$ & $6.7 \%$ & $8.7 \%$ \\
$\mathrm{Si}$ & $16.6 \%$ & $20.8 \%$ & $20.1 \%$ & $15.9 \%$ & $21.3 \%$ & $19.3 \%$ & $15.5 \%$ & $20.5 \%$ & $19.6 \%$ \\
$\mathrm{P}$ & $0.3 \%$ & $0.2 \%$ & $0.2 \%$ & $0.4 \%$ & $0.7 \%$ & $0.6 \%$ & $0.8 \%$ & $1.4 \%$ & $1.3 \%$ \\
$\mathrm{~S}$ & $0.2 \%$ & $0.0 \%$ & $0.0 \%$ & $0.0 \%$ & $0.0 \%$ & $0.0 \%$ & $0.4 \%$ & $0.0 \%$ & $0.0 \%$ \\
$\mathrm{Cl}$ & $0.0 \%$ & $0.0 \%$ & $0.0 \%$ & $0.0 \%$ & $0.0 \%$ & $0.0 \%$ & $0.0 \%$ & $0.0 \%$ & $0.0 \%$ \\
$\mathrm{~K}$ & $0.5 \%$ & $0.9 \%$ & $0.5 \%$ & $0.3 \%$ & $0.6 \%$ & $0.3 \%$ & $0.7 \%$ & $1.3 \%$ & $0.9 \%$ \\
$\mathrm{Ca}$ & $1.8 \%$ & $1.9 \%$ & $1.8 \%$ & $2.3 \%$ & $3.0 \%$ & $2.5 \%$ & $4.4 \%$ & $2.6 \%$ & $2.4 \%$ \\
$\mathrm{Ti}$ & $0.5 \%$ & $0.3 \%$ & $0.3 \%$ & $0.7 \%$ & $0.5 \%$ & $0.4 \%$ & $0.3 \%$ & $0.3 \%$ & $0.3 \%$ \\
$\mathrm{Fe}$ & $1.2 \%$ & $1.9 \%$ & $2.6 \%$ & $0.8 \%$ & $2.1 \%$ & $1.7 \%$ & $2.4 \%$ & $2.3 \%$ & $2.1 \%$ \\
\hline
\end{tabular}

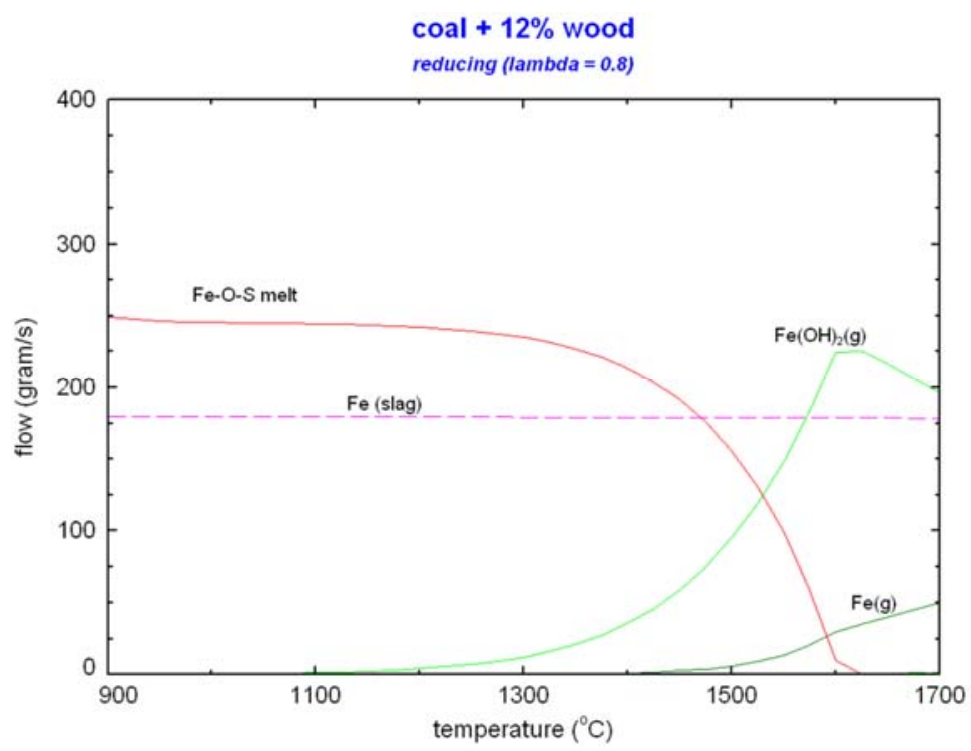

Figure 4.7 Iron compounds, thermodynamic equilibrium co-firing coal with $12 \%$ wood; reducing conditions (air excess factor $=0.8$ ). Solid line: slag phase not included; dashed line: slag phase included. 


\subsubsection{Deposition propensity prediction}

Figure 4.8 shows the results for the calculated deposit measure $\left(m_{\text {molten ash }}{ }^{*} P_{\text {stick }}\right)$ for coal $A$ and coal $B$, co-firing coal $B$ with wood and firing coal with MBM-mix. Coal A was fired during test A9-2 (firing only coal), and coal B was fired during test A9-1 (co-firing coal with wood). The amount of sticky mass strongly increases with temperature around $1,100-1,300{ }^{\circ} \mathrm{C}$. When comparing these results, it is shown that co-firing wood will slightly decrease the amount of sticky material (compare blue and red lines). Comparison with the results of coal A with the other results shows that the influence of coal type is much larger that co-firing $12 \%$ wood. The amount of sticky mass increases with co-firing coal with MBM-mix and the temperature where the amount of sticky mass rapidly increases with temperature drops from 1,300 to $1,200{ }^{\circ} \mathrm{C}$.
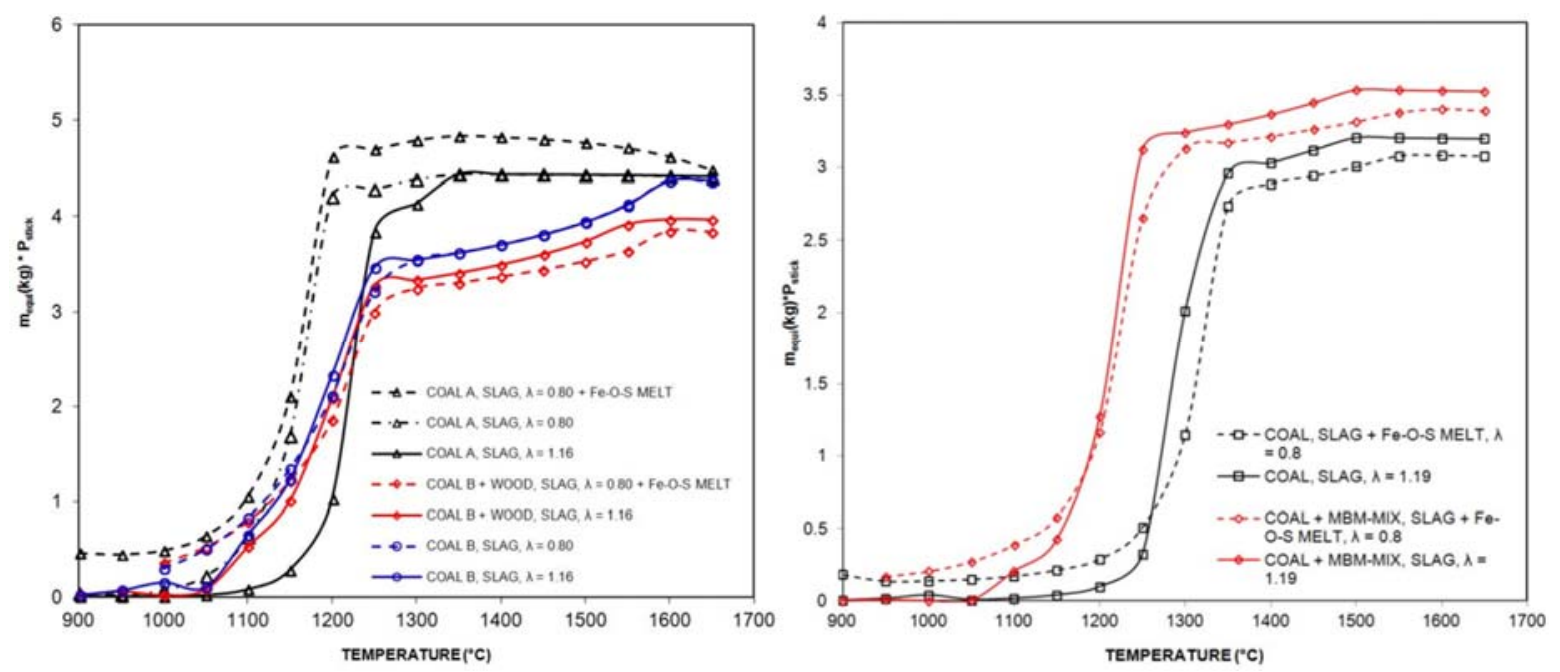

Figure 4.8 Deposit measure or amount of sticky mass for firing coal, co-firing wood (left) and cofiring MBM-mix (right).

Results for coal A (slag only and slag plus Fe-O-S melt) show that ash deposition in the temperature region of $900-1000{ }^{\circ} \mathrm{C}$ is mainly caused by the Fe-O-S melt. The slag phase becomes sticky above $1000{ }^{\circ} \mathrm{C}$ and starts to contribute to the deposition propensity. At $1,300{ }^{\circ} \mathrm{C}$, ash deposition is caused mainly by slag.

\subsection{Discussion}

In this section, the formation of deposited phases is discussed. The composition of deposited molten phases from probe tests and thermodynamic calculation is compared. In addition, the deposition build-up mechanisms are discussed. The goal of these discussions is justify the assumption of the deposition propensity model that the bulk of the deposited phases are molten 
and deposit by inertial impaction. Furthermore, the effect of co-firing on deposition composition and deposition propensity is discussed.

\subsubsection{Formation of phases}

\subsubsection{Al and Si-rich particles (category 1)}

Slag particles (category 1a)

Spherical particles rich in $\mathrm{Al}$ and $\mathrm{Si}$ (in section 3 designated as category 1a) are slag particles formed by melting minerals. Minerals either melt individually, such as illite and muscovite, or different minerals contained in a particle flux [18]. Illite is a major (clay) mineral in coal, and is a major source of ash deposition [19]. Clay minerals may occur in wood as traces [18]. There is no likely interaction between these minerals with coal minerals. In our tests, wood is fed through other burners than coal, and probability of colliding particles is small.

Ca- and P-rich slag particles mostly occur with co-firing MBM-mix with coal and it is assumed that these particles are formed by bone mineral (as part of MBM, meat and bone meal). Bone mineral is approximated by hydroxy(I)apatite, chemical formula $\mathrm{Ca}_{5}\left(\mathrm{PO}_{4}\right)_{3} \mathrm{OH}$, and is referred to as "bioapatite". The EDS-analyses of $10 \mathrm{Ca}$ and P-rich slag particles in the probe deposit resulting from co-firing MBM-mix with coal (see Figure 4.D.1) show that the ratio $\alpha=\mathrm{P}_{2} \mathrm{O}_{5} /\left(\mathrm{P}_{2} \mathrm{O}_{5}+\mathrm{CaO}\right)$ lies between 0.18 and 0.23 . This is in line with the ratio $\alpha$ in bone structures that is usually $P$ deficient compared to stoichiometric hydroxy(I)apatite [20]. The phase diagram of the system CaO- $\mathrm{P}_{2} \mathrm{O}_{5}$ (Figure 4.D.2) shows that liquid is formed only above $1610{ }^{\circ} \mathrm{C}$ for these values of $\alpha$. Hence, the Ca- and P-rich slag particles must have formed before impaction on the probe as bioapatite is not molten at superheaters where the temperature is approximately $1250{ }^{\circ} \mathrm{C}$ and will as such not deposit. Larger, apatite particles not following the streamlines upon their trajectory through the boiler can collide with (smaller) aluminosilicate particles, forming a Ca- and P-rich slag. This explains the higher $\mathrm{Ca}$ and $\mathrm{P}$ in concentration in slag particles resulting from co-firing MBM-mix. In addition, apatite $\left(\mathrm{Ca}_{5}\left(\mathrm{PO}_{4}\right)_{3} \mathrm{OH}\right)$ occurs as a minor mineral in coal, typically $0.7 \%$ of the ash content [21]. Initial contact in the coal matrix between apatite and aluminosilicates can result in fluxing, hence also forming $\mathrm{Ca}$ and $\mathrm{P}$-rich slag particles.

$\mathrm{Al}$ and Si-rich non-molten particles (category $1 \mathrm{~b}$ )

Kaolinite $\left.\left(\mathrm{Al}_{2} \mathrm{Si}_{2}\right)_{5}(\mathrm{OH})_{4}\right)$ is a major mineral in coal, see e.g. [22]. Upon heating (100 to $\left.600{ }^{\circ} \mathrm{C}\right)$, it dehydrates and transforms into meta-kaolinite [23] and upon further heating $\left(925-1,400{ }^{\circ} \mathrm{C}\right)$ it transforms into mullite $\left(\mathrm{Al}_{6} \mathrm{Si}_{2} \mathrm{O}_{13}\right)$ [18]. Both meta-kaolinite and mullite has been identified as mineral phase in coal fly ash [10] using XRD. The kaolinite-mullite transformation, i.e. the ratio of these minerals, is likely dependent on the time-temperature characteristics in the combustion 
zone. The extent to which the meta-kaolinite to mullite transformation has taken place in the particles in the deposits investigated in this chapter cannot be determined using SEM.

\subsubsection{Fe-rich particles (category 2)}

Pyrite $\left(\mathrm{FeS}_{2}\right)$ is the dominant sulphide mineral found in coal [24]. It was shown that typically $62 \%$ of Fe-bearing minerals in bituminous coal are pyrite [25]. Pyrite contained in a burning coal particle will likely react with clay minerals and/or quartz, when present, to form aluminosilicate glass whereas isolated pyrite in coal particles or liberated pyrite will behave differently [15]. CCSEM results suggested that with bituminous coal, $40-60 \%$ of the Fe was associated with glassy ash particles [17]. Pyrite is a combustible mineral: pyrite transformations studies [18] using an entrained flow reactor showed that (liberated) pyrite (particles) initially decomposes as pyrrhotite $\left(\mathrm{Fe}_{0.877} \mathrm{~S}\right)$, fragments, oxidizes where pyrrhotite oxidation occurs from the surface, and being diffusion controlled, this results in an iron oxide shell and a pyrrhotite core. A Fe-O-S melt is formed, and by crystallization magnetite $\left(\mathrm{Fe}_{3} \mathrm{O}_{4}\right)$ and, by further oxidation, hematite $\left(\mathrm{Fe}_{2} \mathrm{O}_{3}\right)$ is formed. This complies with our thermodynamic calculation results for Fe under reducing and oxidizing conditions: if no slag is included, a Fe-O-S melt is stable under reducing conditions and $\mathrm{Fe}_{2} \mathrm{O}_{3}(\mathrm{~s})$ is stable under oxidizing conditions while Fe dissolves in the slag when it is included in the calculations.

The particles classified in this chapter under category 2a likely originate from larger pyrite particles that form a Fe-O-S melt under reducing conditions, of which the surface oxidizes. Upon impaction, spherical particles deform and attain a flat, elliptical shape. An iron oxide skin has formed on the particles' surfaces. Diffusion of $\mathrm{SO}_{2}(\mathrm{~g})$ out of the particles did not fully occur in the particles in deposits resulting from the 1 week test (resulting in category 2a particles), but did fully occur in the 4 week test (resulting in category $2 \mathrm{~b}$ particles). Magnetite has crystallized from the melt, which partly oxidized to hematite. Precipitates can form everywhere in the particles with low $\mathrm{Al}$ and $\mathrm{Si}$ content, resulting in many small crystals. Conversely, in particles with a higher $\mathrm{Al}$ and Si content, the phase has to de-mix to form iron oxide crystals. In the Al and Si-rich remaining fraction may form a glass phase from which precipitation of iron oxide and diffusion of $\mathrm{Fe}$ is constrained, resulting in a limited amount of larger crystals. Pyrite and clay particles interact: most likely due to initial association in the coal. Also, collisions during transport in the boiler between large Fe-O-S particles and slag can occur, but especially for smaller particles, the chance of colliding is small and therefore the larger the fraction of extraneous pyrite, the lower the pyrite fraction available for glass capture [26]. Mixing in the deposit can be constrained as diffusion in solidified slag particles is constrained at temperatures close to the metal surface temperature. 


\subsubsection{Si-rich particles (category 3)}

Particles rich in $\mathrm{Si}$ and $\mathrm{O}$ are likely $\mathrm{SiO}_{2}$, which originates from excluded ('free') quartz. Quartz is one of the most abundant minerals in coal, and is also present in wood as soil contamination. Wood, as well as diatomaceous earth in biomass pellets, (also) contains silicon deposited as a hydrated oxide $\left(\mathrm{SiO}_{2} \cdot \mathrm{nH}_{2} \mathrm{O}\right)$. During combustion $\mathrm{SiO}_{2}$ will form to trydimyte $\left(876^{\circ} \mathrm{C}\right)$ and cristoballite $\left(1,470{ }^{\circ} \mathrm{C}\right)$. In our wood co-firing test and MBM-mix test, Si mass flow with coal is about 925 and 16 times higher compared to wood and MBM-mix, respectively. Hence, $\mathrm{SiO}_{2}$ in co-fired fuel will contribute to deposition less than $\mathrm{SiO}_{2}$ in coal.

\subsubsection{Ca-rich particles (category 4)}

$\mathrm{Ca}$ in bituminous coal is largely present as calcite $\left(\mathrm{CaCO}_{3}\right)$, see e.g. [21]. It will form $\mathrm{CaO}$ and $\mathrm{CO}_{2}$ at combustion temperatures and either not react and remain as free lime $(\mathrm{CaO})$, react with clay minerals and dissolve in the aluminosilicate slag (see preceding sections) mainly found in outer deposit layers, or, according to [15], it may form a fume that reacts with $\mathrm{SO}_{2}$ to form $\mathrm{CaSO}_{4}$ which was found to be present in initial deposits with coal firing. $\mathrm{CaO}$ was found in initial deposits and $\mathrm{CaSO}_{4}$ in more matured deposits with firing wood in a BFB boiler [27]. It was explained that $\mathrm{CaO}$ likely resulted from calcium oxalate present in wood that decomposes during combustion and sulphatizes after it has deposited.

The results from our tests show fine, dispersed, particles consisting of $\mathrm{Ca}, \mathrm{C}$ and $\mathrm{O}$ in the initial deposit of the short-term coal-firing test (see Appendix 4.E), which is likely $\mathrm{CaCO}_{3}$. In the initial deposit of the long-term test co-firing wood with coal, non-porous areas are found consisting mainly of $\mathrm{Ca}, \mathrm{S}$ and $\mathrm{O}$ which is likely $\mathrm{CaSO}_{4}$. Sintering has taken place as all space between the aluminosilicate species is filled with $\mathrm{CaSO}_{4}$ (rather than individual $\mathrm{CaSO}_{4}$ particles), see Appendix 4.E. It was found by [28] that sintering in coal ash deposits can occur by formation of $\mathrm{CaCO}_{3}$ (maximum at $750{ }^{\circ} \mathrm{C}$ deposit temperature) and $\mathrm{CaSO}_{4}$ (maximum at $1200{ }^{\circ} \mathrm{C}$ deposit temperature). In equilibrium, $\mathrm{CaSO}_{4}$ is a more stable component compared to $\mathrm{CaCO}_{3}$. As $\mathrm{CaSO}_{4}$ formation is constrained by the reaction of $\mathrm{SO}_{2}+1 / 2 \mathrm{O}_{2} \leftrightarrow \mathrm{SO}_{3}$ (equilibrium lies at the left side of the reaction at the flue gas temperature at the superheaters), $\mathrm{CaCO}_{3}$ may be formed initially, which can be an explanation that $\mathrm{CaCO}_{3}$ is found in the initial deposit of the short-term test and $\mathrm{CaSO}_{4}$ in the long-term test.

4.4.2 Comparison between measurements and thermodynamic modeling results on molten
phases

The microscopic observations and thermodynamic calculation results on molten phases in the slag are compared to understand the contribution of the molten phases to the deposition. For this 
purpose a slag phase and a Fe-O-S melt (the latter under reducing conditions) are reproduced by thermodynamic calculations.

In the following, the composition of the slag is evaluated as the composition at a certain temperature determines the slag viscosity and thus the sticking probability. The composition of the slag as measured with SEM-EDX is compared with the calculated equilibrium composition. The absolute differences between the calculated and measured slag composition - derived from the results shown in Table 4.4 - is shown in a diagram in Figure 4.9. The diagram shows that the absolute difference for most elements is below $2 \%$ points; in some cases, the difference is larger for elements $\mathrm{O}, \mathrm{Al}$ and $\mathrm{Si}$. Differences between the measured composition and the equilibrium composition are lower at $1,700{ }^{\circ} \mathrm{C}$ compared to $1,300{ }^{\circ} \mathrm{C}$.

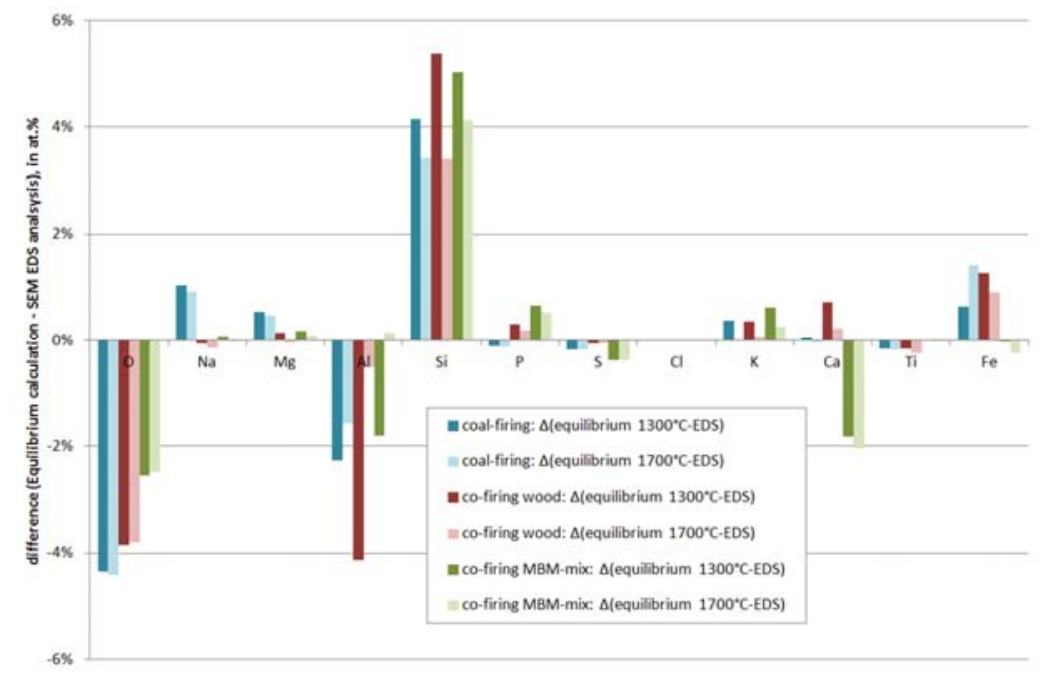

Figure 4.9 Differences between calculated slag composition (equilibrium) at $1300{ }^{\circ} \mathrm{C}$ and 1700 ${ }^{\circ} \mathrm{C}$ and measured slag composition with SEM-EDX. Coal firing, test A9-2; co-firing wood, test A9-1; and co-firing MBM and biomass pellets, test MV1-1.

An explanation of the fact that the calculated Si slag concentration is higher than the measured concentration is as follows. Kaolinite (a major mineral in coal, containing Si) reacts at combustion temperatures:

\section{$3 \mathrm{Al}_{2} \mathrm{Si}_{2} \mathrm{O}_{5}(\mathrm{OH})_{4} \rightarrow \mathrm{Al}_{6} \mathrm{Si}_{2} \mathrm{O}_{13}+4 \mathrm{SiO}_{2}+6 \mathrm{H}_{2} \mathrm{O}$}

In practise, this reaction will progress to a limited extent and if so, the resulting cristoballite $\left(\mathrm{SiO}_{2}\right)$ and mullite $\left(\mathrm{Al}_{6} \mathrm{Si}_{2} \mathrm{O}_{13}\right)$ will be present in one particle, and are not available for further reactions. In equilibrium, mullite is not a stable phase at $1,700{ }^{\circ} \mathrm{C}$, and all $\mathrm{Al}$ and $\mathrm{Si}$ is present in the slag. Mullite is stable below $1,600{ }^{\circ} \mathrm{C}$ and the amount that is stable increases with decreasing temperature. The Al content of the slag therefore drops (cristoballite is only stable below 
approximately $1,200{ }^{\circ} \mathrm{C}$, while $\mathrm{Si}$ is stable as slag component above $1,200{ }^{\circ} \mathrm{C}$ ). Hence, in the equilibrium calculations, Si originating from kaolinite is available to dissolve in the slag and its relative share increases with decreasing temperature, while in practise the Si remains in the original kaolinite particle.

Furthermore, the initial composition of a molten particle will be determined by the composition of the mineral that melts. Minerals like illite, muscovite, K-feldspar, are slag-forming minerals at boiler flue gas temperatures. When different minerals are intensively mixed, a slag can be formed whereby its composition is based on the equilibrium of all the locally present elements. If, however, these minerals are physically not in contact, the (equilibrium) composition of the heated particles will be determined by the individual minerals. For instance, the measured Siconcentration in slag particles is between $15 \%$ and $17 \%$ which is in line with the stoichiometric $\mathrm{Si}$ content of $15.8 \%$ (corrected for $\mathrm{H}$, which cannot be detected by SEM-EDX) in illite / muscovite $\left(\mathrm{KAl}_{2}\left(\mathrm{Si}_{3} \mathrm{Al}\right) \mathrm{O}_{10}(\mathrm{OH})_{2}\right)$, which is the main slag-forming group of mineral in coal. Similarly, minerals as wollastonite $\left(\mathrm{CaSiO}_{3}\right)$ and mellilite $\left(\mathrm{Ca}_{1.5} \mathrm{Na}_{0.5} \mathrm{Al}_{1.1} \mathrm{Mg}_{0.3} \mathrm{Fe}_{0.1} \mathrm{Si}_{1.5} \mathrm{O}_{7}\right)$ will form which are not thermodynamically stable, instead of a Si-rich slag. In summary, minerals may be reactive, but will not react according to equilibrium, mostly due to physical limitations. Also, the estimated availabilities are derived for specific coals and a specific boiler. For other coals and boilers, the element availabilities may deviate.

The difference of $2.5-4 \%$ in $\mathrm{O}$ concentration between equilibrium and EDS analyses can mainly be explained by an over-estimation of $O$ concentration by EDS: two standard samples of $\mathrm{SiO}_{2}$ and $\mathrm{MgO}$ were analyzed which showed an over-estimation of $\mathrm{O}$ content by $2.7 \%$ to $5.4 \%$ at the measuring conditions. This results in 1.7 at\% to 3.4 at\% over-estimation at a measured concentration of 66 at\%. Furthermore, the deviation of the O-content can partly be explained by insufficient compensation for $\mathrm{O}$ in the epoxy resin (epoxy resin is included in an analyses of multiple smaller particles surrounded by resin). Oxygen that can be attributed to epoxy resin, is estimated on basis of the carbon concentration. However, the estimation of epoxy-O somewhat imprecise since small amounts of carbon deposit as a consequence of cracking of oil (oil diffusion pumps are used to maintain the vacuum in the SEM).

Concluding, the slag composition as measured and as predicted with thermodynamic calculations compare well. Deviations of $>2$ \%points may occur for the $\mathrm{Al}$, Si and $\mathrm{O}$ concentration; they are similar with coal and co-firing.

\subsubsection{Deposit build-up mechanisms}

The build-up mechanisms are discussed in order to evaluate whether the deposition propensity prediction model that is based on inertial impaction of molten particles covers the build-up mechanism(s) responsible for the build-up of the bulk of the deposit. 
Particles that cannot follow the stream lines near the probe due to their inertia may impact on the probe surface, a phenomenon commonly referred to as inertial impaction. Particles that are (partly) molten may stick. According to Baxter and DeSollar (1993) [29], inertial impaction is often responsible for the bulk of the ash deposition. Major phases in the deposits are molten slag and Fe-O-S melt. At the upstream side of the probe, particles cannot follow the stream lines near the probe, and impact; larger molten particles deform upon impaction. The relatively small $(<10 \mu \mathrm{m}$ diameter) slag particles deposited at the downstream side of the probe have inertially impacted after following a vortex and escaping the vortex due to centrifugal force. Clearly, inertial impaction and subsequent sticking of molten particles is the most important deposition mechanism in our tests. The deposition propensity model will therefore explain the bulk of the superheater deposits.

Thermophoretic forces, acting as a consequence of a local temperature gradient, are relevant for submicron particles that have homogeneously condensed. As the flue gas temperature at the probe is well above $1,000{ }^{\circ} \mathrm{C}$, condensation of alkalis in the bulk of the flue gas upstream of the probe will not occur. Condensation in the low-temperature layer at the cooled probe surface may occur, followed by subsequent transport by thermophoresis. Condensation can also occur on the relatively cool probe surface. Both thermophoresis and condensation will decrease as the deposit grows and the deposit temperature increases. No $\mathrm{Na}$ and / or K-rich zones have been found with SEM-EDS on the probe surface or on initial deposit particle's surfaces for coal firing, co-firing wood or co-firing MBM-mix, so thermophoresis and condensation plays a negligible role.

Eddy diffusion (i.e. turbulent mixing whereby small vortices transport small particles into the boundary layer and finally to the probe surface) and Brownian diffusion are both transport phenomena that can play a role [30]. However they will have a small contribution to the total mass of the deposit.

\subsubsection{Effect of co-firing}

\subsubsection{Deposit composition}

Co-firing biomass may influence the deposit composition by deposition of particles that originate from biomass, or by influencing the composition of depositing particles originating from coal. The composition of the latter particles may be altered by collision with biomass ash particles or by interaction with gaseous components from biomass.

$\mathrm{CaCO}_{3}$ and $\mathrm{CaSO}_{4}$ have been observed in deposits of the tests with firing coal and co-firing coal with wood. In case of co-firing wood, Ca may originate from calcium oxalate in wood. However, 
the difference in exposition times does not allow for drawing conclusions from the investigated deposits on the effect of co-firing wood on (initial) Ca-based deposits.

MBM-mix is injected in the pf-lines, and the larger bioapatite particles in MBM can collide with molten slag particles. Such particles are clearly visible in the deposits of the test co-firing MBMmix and the concentration of $\mathrm{Ca}$ and $\mathrm{P}$ in deposited slag is higher in this test compared to firing only coal.

Sodium and potassium in wood, MBM and biomass pellets are (mainly) present as water-soluble salts (e.g. as $\mathrm{KCl}$ in wood [11]), and hence are volatile. Opposed to this, the majority of sodium and potassium in coal is mainly present as illite, jarosite $\left(\mathrm{KFe}_{3}\left(\mathrm{SO}_{4}\right)_{2}(\mathrm{OH})_{6}\right)$ or $\mathrm{K}$-feldspar $\left(\mathrm{KAISi}_{3} \mathrm{O}_{8}\right)$ [22]. In both cases, the fate of alkalis in fuel will be mainly slag, either by melting of alkali-containing minerals, or dissolution of volatile alkalis in molten slag. The measured concentrations of $\mathrm{Na}$ and $\mathrm{K}$ in slag particles originating from coal and co-firing in our tests are similar. It is however expected that with higher co-firing rates, the alkali concentration in slag will increase due to the increased ratio of volatile alkalis to molten slag.

$\mathrm{Na}$ and $\mathrm{K}$ can be absorbed on the surface of kaolinite particles by diffusion and reaction with the aluminium silicate structure with straw combustion [23]. From tests with kaolin additives with lignite $(2-3 w t \%$ of the coal), it was concluded that sodium can be effectively captured with kaolin [31]. The $\mathrm{K}$ concentration in meta-kaolinite particles in deposits of coal and co-firing wood of our tests are measured to be $0.1-0.2$ at.\% and $0.1-0.3 \%$, respectively; Na concentrations are $0.2-0.3 \%$ and $0.3 \%$, respectively. As these concentrations are similar, this does not illustrate the aforementioned alkali-(meta-)kaolinite interactions. With co-firing MBM-mix, the $\mathrm{K}$ and $\mathrm{Na}$ concentrations in meta-kaolinite are $0.3-0.5 \%$, and $0.3-0.4 \%$, respectively. The $\mathrm{K}$ concentration in kaolinite particles is thus higher with co-firing MBM-mix, which is explained by the higher amount of volatile $\mathrm{K}$ during combustion with co-firing MBM-mix compared to firing coal.

\subsubsection{Deposition propensity}

Regarding the prediction results as shown in Figure 4.8, the mass of molten slag reduces with co-firing wood compared to firing coal, by which the slagging propensity decreases. For oxidizing conditions, the viscosity above $1200{ }^{\circ} \mathrm{C}$ is lower with co-firing wood compared to firing coal, thereby increasing the sticking probability. The slag viscosity is lower as the concentration of $\mathrm{SiO}_{2}$ (a network former) is lower. The combined effect is that the slagging propensity with cofiring wood is lower than with firing coal, and the lowest under reducing conditions (compare red and blue lines in Figure 4.8, left). The mass of molten slag increases with co-firing MBM-mix, increasing the slagging propensity. The slag viscosity is lower with co-firing MBM-mix compared to firing coal for both reducing and oxidizing conditions. This is due to the decrease of the concentration of $\mathrm{SiO}_{2}$ (network former) and the increase of $\mathrm{CaO}$ (network modifier). The 
combined effect is that the slagging propensity increases when firing MBM-mix, compared to coal (see Figure 4.8, right).

The fact that calculation results show that changing from firing coal to co-firing $12.2 \%$ wood has much less impact on deposition propensity than a changing coal type or changing to co-firing $4 \%$ MBM-mix is explained by the small contribution of wood to the total amount of ash (see section 4.2.1).

\subsection{Conclusions}

The bulk of the deposits are formed by molten particles: mainly slag and Fe-O-S melt (originating mainly from coal ash minerals). The concentration of $\mathrm{Ca}$ and $\mathrm{P}$ in slag particles increases with co-firing MBM(-mix) originating from bio-apatite in MBM. Although alkalis in biomass are

generally more volatile, the concentration of $\mathrm{Na}$ and $\mathrm{K}$ in slag particles in deposits from firing coal, co-firing $12 \%$ wood and $4 \%$ MBM-mix (on basis of thermal heat input) is comparable. The $\mathrm{K}$ concentration in (meta-)kaolinite particles from co-firing MBM-mix was however slightly higher. Alkalis present in the co-fired biomass are mainly present as water-soluble salts and will readily evaporate during combustion. However, no alkali-rich zones have been identified on the probe surface or in the initial deposit.

Thermodynamic calculations are suitable to predict the molten phases (slag and Fe-O-S melt) responsible for the bulk of the formed deposits. The slag composition as measured and as predicted with thermodynamic calculations compare well.

With firing coal, and co-firing $12 \%$ wood or $4 \%$ MBM-mix with coal, the bulk of the deposits on the superheater probes are formed by inertial impaction of molten particles. This was also the assumption for the deposition propensity prediction model and this assumption is hence justified.

The predictions show a decrease of slagging propensity with co-firing wood, and an increase with co-firing MBM-mix, compared to firing coal. This is in line with operating experience. The change of slagging propensity is caused by change of the amount of slag (mass) and viscosity. The change in slagging propensity when comparing coal firing to co-firing wood is smaller than the change in slagging propensity when comparing two different coals.

\section{References}

[1] Harding NS, O'Connor DC. Ash deposition impacts in the power industry. Fuel Proc Tech, 2007, 88, 1082-93. 
[2] Pronobis M. Evaluation of the influence of biomass co-combustion on boiler furnace slagging by means of fusibility correlations. Biom Bioener, 2005, 28, 375-83.

[3] Heinzl T, Siegle V, Spliethoff H, Hein KRG. Investigation of slagging in pulverized fuel cocombustion of biomass and coal at a pilot-scale test facility. Fuel Proc Tech, 1998, 54, 109-25.

[4] Smajevic I, Kazagic A, Music M, Becic K, Hasanbegovic I, Sokolovic S, Delihasanovic N, Skopljak A, Hodzic N. Co-firing Bosnian coals with woody biomass: experimental studies on a laboratory-scale furnace and 110 MWe power unit. Therm Sci, 2012, 16, 789-804.

[5] Plaza, PP. The development of a slagging and fouling predictive methodology for large scale pulverised boilers fired with coal/biomass blends. PhD Thesis, Cardiff University, 2013.

[6] Doshi V, Vuthaluru HB, Korbee R, Kiel JHA. Development of a modeling approach to predict ash formation during co-firing of coal and biomass. Fuel Proc Tech, 2009; 90, 1148-56.

[7] Bale CW, Chartrand P, Degterov SA, Eriksson G, Hack K, Ben Mahfoud R, et al. FactSage Thermochemical Software and Databases. CALPHAD, 2002; 26, 189-228.

[8] Becidan M, Sørum L, Frandsen F, Pedersen AJ. Corrosion in waste-fired boilers: A thermodynamic study. Fuel, 2009, 88, 595-604.

[9] Heikkinen, J. Characterisation of supplementary fuels for co-combustion with pulverised coal. PhD thesis, TUDelft, 2005.

[10] Vassilev SV, Menendez R, Alvarez D, Diaz-Somoanob M, Martinez-Tarazonab MR. Phasemineral and chemical composition of coal fly ashes as a basis for their multicomponent utilization.

1. Characterization of feed coals and fly ashes. Fuel, 2003, 82, 1793-811.

[11] Zevenhoven-Onderwater M. Ash-Forming Matter in Biomass Fuels [dissertation]. Turku: Åbo Akademi; 2001.

[12] Tortosa Masiá AA, Buhre BJP, Gupta RP, Wall TF. Use of TMA to predict deposition behaviour of biomass fuels. Fuel, 2007, 86, 2446-56.

[13] Walsh PM, Sayre AN, Loehden DO, Monroe LS, Beér JM, Sarofim AF. Deposition of bituminous coal ash on an isolated heat exchanger tube: effects of coal properties on deposit growth. Prog Energ Comb Sci, 1990, 16, 327-45.

[14] McLennan AR, Bryan BS, Stanmore BR, Wall TF. Ash formation machanisms during pf combustion in reducing condition. Energ Fuel, 2000, 14, 150-9. 
[15] Huffman GP, Huggins FE, Shah N, Shah A. Behavior of basic elements during coal combustion. Prog Ener Comb Sci, 1990, 16, 243-51.

[16] Srinivasachar S, Helble JJ, Boni AA. Mineral behavior during coal combustion 1. Pyrite transformations. Prog Ener Comb Sci, 1990, 16, 281-92.

[17] Helble JJ, Srinivasachar S, Boni AA. Factors influencing the transformation of minerals during pulverized coal combustion. Prog Ener Comb Sci, 1990, 16, 267-79.

[18] Bryers, R.W. Fireside slagging, fouling and high-temperature corrosion of heat transfer surface due to impurities in steam-raising fuels. Prog Ener Comb Sci, 1996, 22, 29-120.

[19] Srinivasachar S, Helble JJ, Boni AA, Shah N, Huffman GP, Huggins FE. Mineral behavior during coal combustion 2. Illite transformations. Prog Ener Comb Sci, 1990, 16, 293-302.

[20] Pellegrino E, Biltz RM. Bone Carbonate and the Ca to P Molar Ratio. Nature, 1968, 219, $1261-2$.

[21] Vassilev SV, Vassileva CG. A new approach for the combined chemical and mineral classification of the inorganic matter in coal. 1. Chemical and mineral classification systems. Fuel, 2009, 88, 235-245.

[22] Renton JJ. Semiquantitative determination of coal minerals. In: Mineral matter and ash in coal, pp. 53 - 60 (Ed. K.S. Vorres) ISBN 0841209596, 1986.

[23] Steenari BM, Lindqvist $O$. High temperature reactions of straw ash and the anti-sintering additives kaolin and dolomite. Biom Bioen, 1998, 14, 67-76.

[24] Gluskoter HJ. Organic sulphur in coal, in Proceedings of 169th National Meeting of the American Chemical Society, Division of Fuel Chemistry, Vol. 20, pp. 94-96, American Chemical Society, Washington, D.C. (1975).

[25] Huffman GP, Huggins FE. Analysis of inorganic constituents in low rank coal, The Chemistry of Low Rank Coal, HH Schobert (Ed.), pp. 159-174, ACS Advances in Chemistry Series, American Chem. Soc., Washington, D.C. (1984).

[26] Bool LE, Peterson TW, Wendt JOL. The partitioning of iron during the combustion of pulverized coal. Comb Flame, 1995, 100, 262-70. 
[27] Stam AF, Haasnoot K, Brem G. Superheater fouling in a BFB boiler firing wood-based fuel blends. Fuel, 2014, 135, 322-31.

[28] Skrifvars B-J, Hupa M, Backman R, Hulturnen M. Sintering mechanisms of FBC ashes. Fuel, 1994, 73, 171-6.

[29] Baxter LL, DeSollar RW. A mechanistic description of ash deposition during pulverized coal combustion: predictions compared with observations. Fuel, 1993, 72, 1411 - 18.

[30] Zhou H, Jensen PA, Frandsen FJ. Dynamic mechanistic model of superheater deposit growth and shedding in a biomass fired grate boiler. Fuel, 2007, 86, $1519-1533$.

[31] Vuthaluru HB. Remediation of ash problems in pulverised coal-fired boilers. Fuel, 1999, 78, 1789-1803.

[32] FactSage website: http://www.crct.polymtl.ca/fact/phase_diagram.php?file=Ca-P-O_CaOP2O5.jpg\&dir=FToxid. Last accessed: 14 August 2017. 

CONVERSION AND USE OF ADDITIVES - A THERMODYNAMIC APPROACH

\subsection{Introduction}

It is the experience of operators of coal-fired power plants in the Netherlands, that with co-firing limited amounts of biomass (i.e. up to $20 \%$ wood, all co-firing percentages in this chapter are on basis of fuel mass (a.r.) input unless stated otherwise), deposition of molten salts and hightemperature corrosion does not increase compared to firing only coal. However, fouling and corrosion can be problematic with firing only biomass in dedicated biomass boilers, [1], [2]. It is currently considered in The Netherlands to either increase biomass co-firing rates or to convert coal-fired boilers to fire only biomass. Co-firing percentages of over $20 \%$ biomass with coal have been demonstrated in The Netherlands only on experimental basis. Full scale results regarding fouling in coal-fired boilers with fuel blends similar to those as fired in The Netherlands, have - to the knowledge of the authors - not been published in the open literature. Due to the differences in fuel composition and firing temperature (the maximum firing temperature in coal-fired boilers is normally (much) higher than in dedicated biomass boilers), the interaction of $\mathrm{K}$ and $\mathrm{Na}$ with ash forming matter may be fundamentally different in coal vs. biomass boilers and cause different composition and amount of deposits. For example, [3] concluded from a study with co-firing straw with coal in a dedicated coal boiler that $\mathrm{K}$ in deposits was mainly associated with aluminosilicates whereas [1] observed $\mathrm{K}$ as $\mathrm{K}_{2} \mathrm{SO}_{4}$ in deposits with firing straw. Several additives exist to reduce fouling and corrosion problems: coal fly ash [4], kaolinite [5] and S-based additives [6].

After devolatilization of alkalis, they can interact with aluminosilicates, i.e. dissolve in the glass phase or be chemisorbed by kaolinite. The remaining volatile alkalis will condense upon cooling of the flue gases. This can be heterogeneous or homogeneous condensation. In the latter case, aerosols form that can build up on tubes to form a molten alkali salt deposit of various compositions. Problematic alkali deposits occur generally at a flue gas temperature of around $700{ }^{\circ} \mathrm{C}$, as for example was observed for a boiler converted from coal to straw, see [7].

The first objective of this chapter is to investigate the high temperature process (above approximately $900{ }^{\circ} \mathrm{C}$ ) of interaction between $\mathrm{K}, \mathrm{Na}$ and fuel ash when (co-) firing biomass in dedicated coal boilers, i.e. how this interaction is influenced by the chemical composition of the glass phase. This is done by a) investigating fly ashes generated with full-scale biomass co-firing experiments with Scanning Electron Microscopy (SEM) and b) simulating the behaviour of alkalis during combustion with thermodynamic equilibrium calculations. Cases of coal and biomass (co)firing are analysed, as well as adding coal fly ash with only biomass combustion. The second objective is to investigate the effect of the elemental ratio of $\mathrm{K}, \mathrm{Na}, \mathrm{S}$ and $\mathrm{Cl}$ on the low temperature process (below approximately $900{ }^{\circ} \mathrm{C}$ ) of formation of molten alkali salt. This is again done by thermodynamic calculations, simulating the chemistry during combustion of coal 
and biomass (co-) firing, as well as addition of ammonium sulphate $\left(\left(\mathrm{NH}_{4}\right)_{2} \mathrm{SO}_{4}\right)$ with firing only biomass. As a result, the fouling tendency with firing coal and/or biomass, with and without additives is predicted.

The most used co-firing fuel in The Netherlands is wood, while specific plants use a mixture of MBM (Meat and Bone Meal) and biomass pellets (in this chapter referred to as "MBM-mix"), or a mixture of sheanut and other biomass (in this chapter referred to as "Sheanut-mix"). Biomass pellets are made from a mixture of wood, paper sludge, diatomaceous earth, composted municipal sewage sludge and coffee grounds. SEM investigations of fly ash and thermodynamic calculations have been performed for these fuel blends as they represent a broad mix of chemical compositions of fuels. Typical fuel compositions are given in Appendix 5.A.

\subsection{Experimental and modelling}

\subsubsection{Samples}

Pulverized fuel Fly Ash (PFA) has been generated during biomass co-firing trials in three different two-pass, tangentially-fired, coal-fired boilers with staged combustion. Wood was co-fired in Amer unit 9 (640 $\mathrm{MW}_{\mathrm{e}}$, operated by RWE), MBM-mix was co-fired in Maasvlakte unit 1 (518 $\mathrm{MW}_{\mathrm{e}}$, operated by Uniper) and sheanut-mix was co-fired in Borssele unit 12 (408 $\mathrm{MW}_{\mathrm{e}}$, operated by EPZ). PFA's have been collected from the Electrostatic Precipitator (ESP) from the collection tank (PFA-C), see Table 5.1, and have been investigated with SEM.

Table 5.1 Samples taken from PFA-C (Pulverized fuel Fly Ash from Collection tank)

\begin{tabular}{lllll}
\hline Coal & secondary fuel & fuel mass input & thermal heat input & ash input \\
\hline Blend & MBM mix & $26.1 \%$ & $18 \%$ & $34.3 \%$ \\
Blend & sheanut mix & $26.8 \%$ & $21 \%$ & $16.4 \%$ \\
Blend & wood & $9 \%$ & $7 \%$ & $0.67 \%$ \\
Blend & wood & $18.8 \%$ & $15 \%$ & $1.6 \%$ \\
Blend & wood & $44.6 \%$ & $38 \%$ & $5.2 \%$ \\
\hline
\end{tabular}




\subsubsection{Microscopic investigations}

For microscopic investigations, the samples were put in slow-curing epoxy resin and cross sections were grinded and polished, using water-free mediums. Carbon was deposited on the sample surface to overcome charging during SEM investigations. The used SEM system is a JEOL JSM-6300. Backscatter electron images (BEI) and secondary electron images (SEI) were made and the composition was analysed on micro-scale level with EDS (Energy Dispersive x-ray Spectroscopy). Use is made of a ThermoFisher Scientific Silicon Drift Detector and Noran System Six software for data processing. Mappings are made (net counts and element concentrations) that are further processed using KEMPhase; KEMPhase is an in-house developed tool which enables the results of EDS analysis to be presented as false colour representations of the distribution of predefined phases. A phase is defined by a bandwidth of element concentrations specified by the user. The element concentrations in every individual pixel of the back scatter image are checked and the pre-defined phase is designated per pixel.

\subsubsection{Thermodynamic modelling}

\subsubsection{Thermodynamic approach}

The computer programme FactSage (see [8] for a general description) has been used to calculate thermodynamic equilibrium. Limitations of thermodynamic equilibrium calculations in order to simulate the behaviour of inorganic elements during combustion have been reviewed by [9] and in addition, how the drawbacks of an equilibrium approach can be accounted for. The residence time of particles in the boiler is in the order of seconds, and the maximum temperature that is reached is about $1,700{ }^{\circ} \mathrm{C}$. It is expected that especially the larger particles will not (completely) reach the equilibrium state during combustion, and kinetic limitations play an important role. This is accounted for by selection of the database components that can be expected on basis of mineralogical analyses of fly ashes, as commonly found in literature (see Appendix 5.B for the list of selected compounds). In equilibrium, concentration gradients are not taken into account. The effect of variation in oxygen concentration is approached by simulating extreme cases of oxidizing and reducing conditions. Physical processes are not taken into account in equilibrium, which is accounted for by complementing the calculations with experimental data (in this chapter a number of PFA's generated with full-scale trials have been analysed). Results of equilibrium calculations are dependent on the database content. This is taken into account by using FactSage which includes an extensive component and solution database, e.g. including slag and molten salts. Also the mode of occurrence of elements in the fuel is neglected: this is taken into account by introducing availability of elements for coal and biomass, as described in following sections. 


\subsubsection{Availability of elements in coal}

The mode of occurrence of elements in the fuel determines if an element behaves inert (i.e. 'not available for reaction') or is reactive (i.e. 'available for reaction'). The availability for reaction of inorganic elements in coal is based on the comparison of the mineral composition of coal ash and fly ash. When comparing this coal ash and fly ash mineral compositions, it appears that some minerals (partly) transform during combustion (i.e. a lower concentration of the mineral in the fly ash than in the coal ash) while other minerals are formed (i.e. a higher concentration of the mineral in the fly ash than in the coal ash). The change per mineral is calculated using the dataset of [10]. The availability of main elements in coal is derived based on these mineral changes, see (first column of) Table 5.2 for results. A more detailed description of deriving element availability is given in Appendix 5.C. The available fraction (availability multiplied by element concentration in the fuel) is input for the equilibrium calculations.

Table 5.2 Calculated element availabilities

\begin{tabular}{llllll}
\hline element & coal & wood & MBM & $\begin{array}{l}\text { biomass } \\
\text { pellets }\end{array}$ & Sheanut \\
\hline $\mathrm{Si}$ & $58 \%$ & $58 \%$ & $59 \%$ & $58 \%$ & $60 \%$ \\
$\mathrm{Al}$ & $63 \%$ & $63 \%$ & $63 \%$ & $63 \%$ & $63 \%$ \\
$\mathrm{Fe}$ & $66 \%$ & $66 \%$ & $66 \%$ & $66 \%$ & $66 \%$ \\
$\mathrm{Ca}$ & $59 \%$ & $68 \%$ & $61 \%$ & $69 \%$ & $74 \%$ \\
$\mathrm{Mg}$ & $69 \%$ & $87 \%$ & $75 \%$ & $74 \%$ & $79 \%$ \\
$\mathrm{Na}$ & $68 \%$ & $100 \%$ & $100 \%$ & $91 \%$ & $100 \%$ \\
$\mathrm{~K}$ & $62 \%$ & $100 \%$ & $100 \%$ & $79 \%$ & $100 \%$ \\
$\mathrm{Ti}$ & $69 \%$ & $69 \%$ & $69 \%$ & $69 \%$ & $69 \%$ \\
$\mathrm{P}$ & $69 \%$ & $69 \%$ & $69 \%$ & $69 \%$ & $71 \%$ \\
$\mathrm{~S}$ & $45 \%$ & $91 \%$ & $91 \%$ & $98 \%$ & $100 \%$ \\
$\mathrm{Cl}$ & $69 \%$ & $100 \%$ & $100 \%$ & $100 \%$ & $100 \%$ \\
\hline
\end{tabular}

\subsubsection{Availability of elements in biomass}

Often, biomass is characterized with chemical fractionation (CF) and the elements in the fuel are regarded available for reaction to the extent that they are soluble in water or ammonium acetate solution [11] (or more solutions over a wider $\mathrm{pH}$-range in combination with leaching simulation, as described in [12]). This available fraction is interpreted as being water soluble salts and organically bound elements. The remainder, soluble in an $\mathrm{HCl}$ solution or non-soluble, is traditionally considered to consist of nonreactive minerals, and is not taken into account in the equilibrium calculations, see Figure 5.1. The drawback of this traditional approach by [11] is that 
$\mathrm{Si}, \mathrm{Al}$ and $\mathrm{Fe}$ are thereby (mostly) considered non-reactive and that no or only very little slag formation and alkali-ash interaction is taken into account. [13] therefore assumed a reactive layer, complementary to the CF results. A higher availability of refractory elements is yielded with method as described in [12] but results published in the open literature on different biomass fuels are limited.

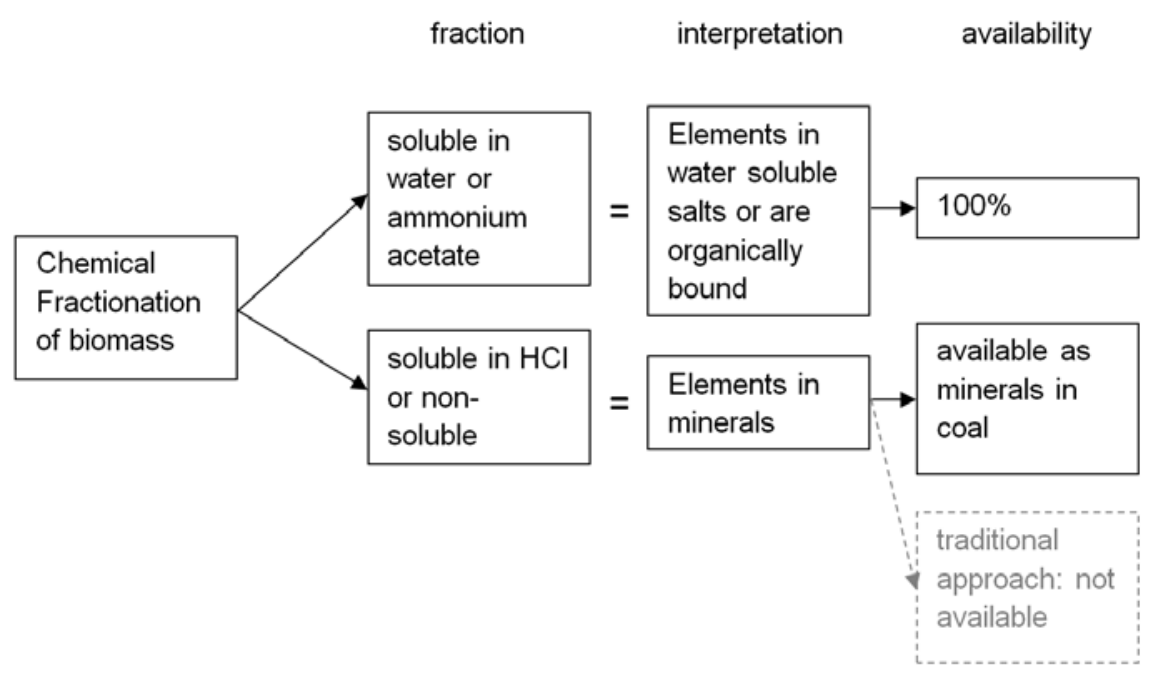

Figure 5.1 Availability of elements in biomass for reaction.

Our approach differs from the traditional approach taken by [11] who applied the method for fluidized bed combustion. With pulverized fuel combustion, maximum flue gas temperatures are much higher than with fluidized bed combustion (approximately $1,700{ }^{\circ} \mathrm{C}$ compared to $900{ }^{\circ} \mathrm{C}$ ). We therefore assume, in case of pulverized fuel combustion, that minerals in biomass are at least as available as the minerals in coal, see Figure 5.1. The calculated availabilities are presented in Table 5.2. As an example: $\mathrm{Si}$ in wood is only soluble in $\mathrm{HCl}$ or non-soluble, and in the traditional approach the availability would be $0 \%$; in our approach the availability if $\mathrm{Si}$ is equal to that in coal, i.e. $58 \%$. For MBM and sheanut, a small part of the $\mathrm{Si}$ is soluble in water or ammonium acetate: the availability of that (small) part is $100 \%$ whereas the largest part is soluble in $\mathrm{HCl}$ or non-soluble and the availability of that (largest) part is again $58 \%$. As a result, the availability of $\mathrm{Si}$ in MBM and sheanut is slightly higher than $58 \%$. The CF results have been obtained from [14] and since no results are available for sheanut, results for olive residue have been used as ultimate and proximate analysis are quite alike. Our approach also differs from the approach from [13]. The reactive part is in our approach quantified based on coal ash and fly ash comparison whereas [13] assume a range of different thicknesses of the reactive layer.

The conditions are "during combustion", i.e. oxidizing (air excess factor $\lambda=1.16$ ) and reducing ( $\lambda$ $=0.8$ ) conditions and a temperature range of $1,700{ }^{\circ} \mathrm{C}$ to $300{ }^{\circ} \mathrm{C}$. As no interaction between gas and slag is expected below $900{ }^{\circ} \mathrm{C}$, the gas phase is extracted at $900{ }^{\circ} \mathrm{C}$ (alkalis condensed > 
$900{ }^{\circ} \mathrm{C}$ are also added) and cooling to $300{ }^{\circ} \mathrm{C}$ is simulated separately (furthermore, problematic alkali deposits are expected below a temperature of $900{ }^{\circ} \mathrm{C}$ ). The model is used to calculate the distribution of $\mathrm{K}$ and $\mathrm{Na}$ over different phases, i.e. gas, solid, slag and molten salt as function of fuel blend and use of additive (i.e. chemical composition). Coal fly ash addition is simulated by taking these ashes into account in the temperature range $\geq 900{ }^{\circ} \mathrm{C}$, allowing for uptake of alkalis in the ash. Ammonium sulphate addition is simulated by taking it into account in the temperature range $\leq 900^{\circ} \mathrm{C}$.

\subsection{Results}

\subsubsection{Microscopic investigations}

Figure 5.2 shows a BEI of cross-sectioned particles from PFA-C from co-firing 18\% MBM-mix. The pre-defined phases "K-containing" and aluminosilicates with different K-concentration are shown. The majority of the particles contain $\mathrm{K}$ in a concentration $>0.2 \%$. $\mathrm{K}$ is mainly associated

with aluminosilicates. The areas where the phase "K-containing" and aluminosilicates containing potassium do not overlap (i.e. the blue area in Figure 5.2) are unburnt particles, non-flat surfaces or at the edges of particles or at very small particles. These results are not taken into account as in unburnt particles, aluminosilicates are not recognized due to low Al and Si concentration and with non-flat surfaces and at particles' edges, the element concentration calculation from XRFspectra is incorrect since either correction factors do not apply or due to noise reduction. The same observation as for $\mathrm{K}$ is made for $\mathrm{Na}$ which is also mainly associated with aluminosilicates; these observations were also made for fly ash samples from co-firing 7, 15 and $38 \%$ wood and $21 \%$ sheanut-mix. 


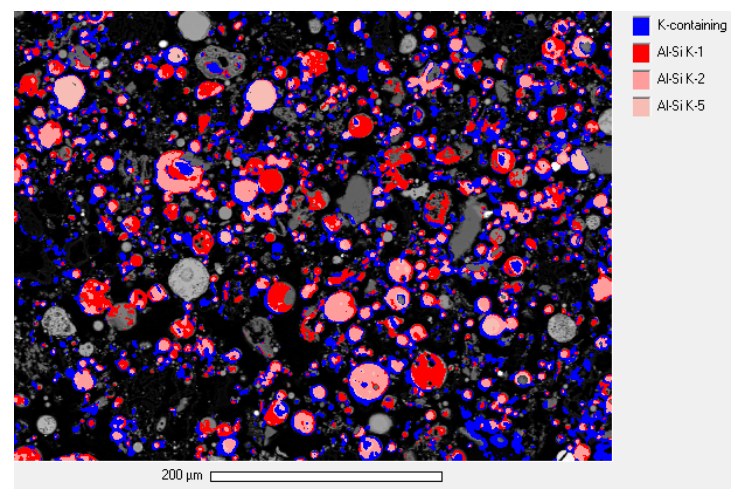

Figure 5.2 Back scatter image of cross-sectioned particles from PFA-C from co-firing 18\% MBM-mix. The pre-defined phases are shown: "K-containing" (K concentration > $0.2 \%$ ), "Al-Si K-5 "(aluminosilicates with K concentration 2-5\%), "Al-Si K-2" (idem, 1-2\%), "Al-Si K-1" (idem, 0.5-1\%); Al-Si phases contain $3.5-23.5 \%$ Al\% and $4.5-$ $31 \% \mathrm{Si}$.

No enrichment of either $\mathrm{K}$ or $\mathrm{Na}$ was observed at the edge of cross-sectioned particles (i.e. at particle surfaces). As the effect noise reduction is less influencing enrichment with higher magnifications, 1,000x magnifications were made in addition to the 250x magnifications (the latter as in Figure 5.2). No K or Na-enrichment was observed at the edges for any of the five ash samples.

Observed aluminosilicates in the fly ash samples are slag and kaolinite-like particles. Slag particles are spherical. Kaolinite-like particles are porous, arbitrarily-shaped and the chemical composition is approximately that of meta-kaolinite $\left(\mathrm{Al}_{2} \mathrm{O}_{3} \cdot \mathrm{SiO}_{2}\right)$, de-hydroxyled kaolinite. Upon heating, meta-kaolinite decomposes into mullite and $\mathrm{SiO}_{2}$. Whether the observed kaolinite-like particles are meta-kaolinite or are mixture of mullite and $\mathrm{SiO}_{2}$ cannot be established with SEM ([10] observed both kaolinite and mullite in coal fly ash using XRD). The average concentration of $\mathrm{K}$ and $\mathrm{Na}$ in the glass phase and in kaolinite-like particles was determined by averaging the average particle concentrations of respectively $>20$ (slag) and $>6$ particles (kaolinite-like) per fly ash sample. The average concentration was determined by an area analysis in the area of a cross-sectioned particle. The average $\mathrm{K}$ and $\mathrm{Na}$ concentration in glass particles is higher than in kaolinite-like particles. The $\mathrm{K}$ and $\mathrm{Na}$ concentration in the glass lies between 0.3 and $3.5 \%$, respectively 0.3 and $1 \%$, while in kaolinite-like particles they lie between 0.14 and $2.1 \%$, respectively 0.18 and $0.5 \%$. The fly ash mainly consists of glass and contains only little kaolinitelike particles. Hence, $\mathrm{K}$ is mainly associated with slag and to a smaller extent with kaolinite. The concentration of $\mathrm{K}$ in glass is compared for different fuel blends and reads $0.3 \%(20 \%$ wood), $1.3 \%(18 \%$ MBM-mix), and $3.5 \%$ (21\% sheanut-mix). The Na glass concentration is the lowest with sheanut-mix $(0.3 \%)$ and the highest with MBM $(0.8 \%)$. 


\subsubsection{Thermodynamic equilibrium calculations}

\subsubsection{Temperature range $1,700-900{ }^{\circ} \mathrm{C}$}

The share of gaseous $\mathrm{K}$ increases with temperature and biomass co-firing rate, see for example Figure 5.3 for co-firing wood. Under oxidizing conditions, gaseous $\mathrm{K}$ is mainly $\mathrm{KOH}$ and $\mathrm{KCl}$ and some $\mathrm{K}$ (especially at $1,700{ }^{\circ} \mathrm{C}$ ) and $\mathrm{K}_{2} \mathrm{SO}_{4}$; for reducing conditions, gaseous $\mathrm{K}$ is mainly $\mathrm{KOH}$, $\mathrm{KCl}$ and $\mathrm{K}$. The increase of gaseous $\mathrm{K}$ share is the highest with co-firing wood and the lowest with co-firing MBM for both oxidizing and reducing conditions.
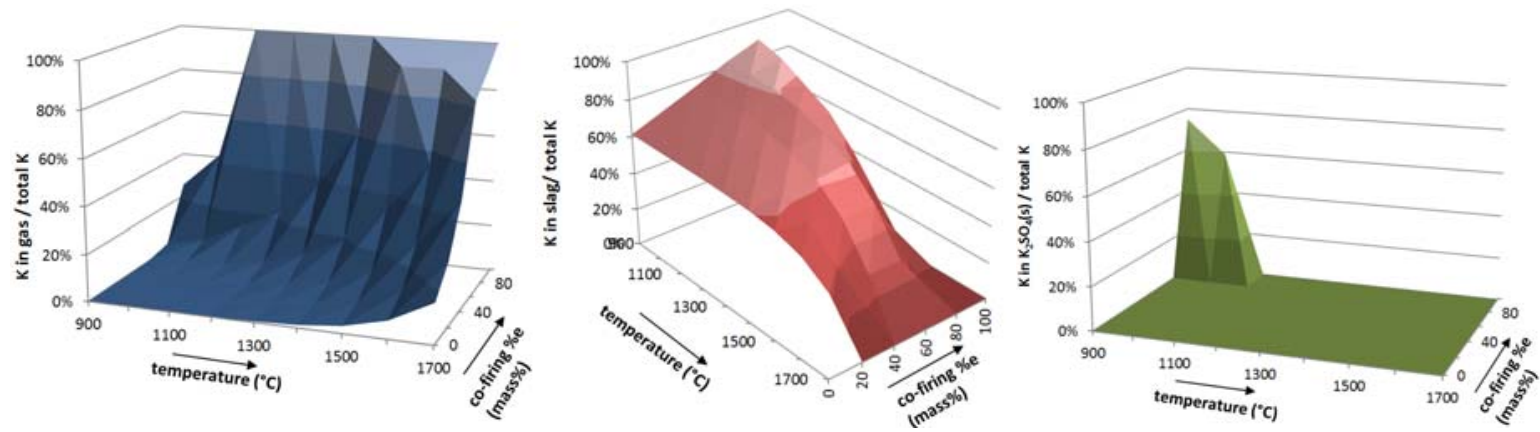

Figure 5.3 Thermodynamic equilibrium results: distribution of $\mathrm{K}$ over gas, slag and solids for co-firing $0-100 \%$ wood, $900-1,700{ }^{\circ} \mathrm{C}$, oxidizing conditions $(\lambda=1.16)$.

The behaviour of $\mathrm{Na}$ is quite similar to $\mathrm{K}$ : an increase of gaseous $\mathrm{Na}$ with temperature and cofiring rate. However, for co-firing sheanut-mix and MBM-mix, the share of gaseous $\mathrm{Na}$ is lower compared to $\mathrm{K}$ while the share of $\mathrm{Na}$ in slag is higher compared to $\mathrm{K}$. Under oxidizing conditions, gaseous $\mathrm{Na}$ is mainly $\mathrm{NaOH}$, and some $\mathrm{Na}$ and $\mathrm{NaCl}$, except when co-firing MBM-mix: $\mathrm{NaCl}$ and $\mathrm{NaOH}$ are both main gas species. Under reducing conditions, $\mathrm{Na}(\mathrm{g})$ and $\mathrm{NaOH}$ are main gas species while some $\mathrm{NaCl}(\mathrm{g})$ is present.

\subsubsection{Temperature range $900-300^{\circ} \mathrm{C}$}

The formation of molten $\mathrm{K}-\mathrm{Na}-\mathrm{SO}_{4}-\mathrm{Cl}$ salt has been simulated for the temperature range $300-$ $900{ }^{\circ} \mathrm{C}$. Results for co-firing wood are shown in Figure 5.4 (top, left). The amount of molten salt is fairly constant over the whole temperature range for co-firing $0-90 \%$ wood; salt formation rapidly increases above $90 \%$ co-firing and most salt is present at $625{ }^{\circ} \mathrm{C}$. The effect of adding coal fly ash (composition taken from [15], see Appendix A) as additive to counteract molten salt formation has been simulated for adding $0.1,1$ and 10 gram fly ash per MJ net power production $\left(1 \mathrm{~g} \mathrm{~s}^{-1} / \mathrm{MW}_{\mathrm{e}}=1 \mathrm{~g} \mathrm{MJ}^{-1}\right)$; results are shown in Figure 5.4 (top, right). Molten salt formation slightly reduces when adding $0.1 \mathrm{~g} \mathrm{MJ}^{-1}$. Adding $1 \mathrm{~g} \mathrm{MJ}^{-1}$ results in a level of molten salt formation comparable to firing only coal. 

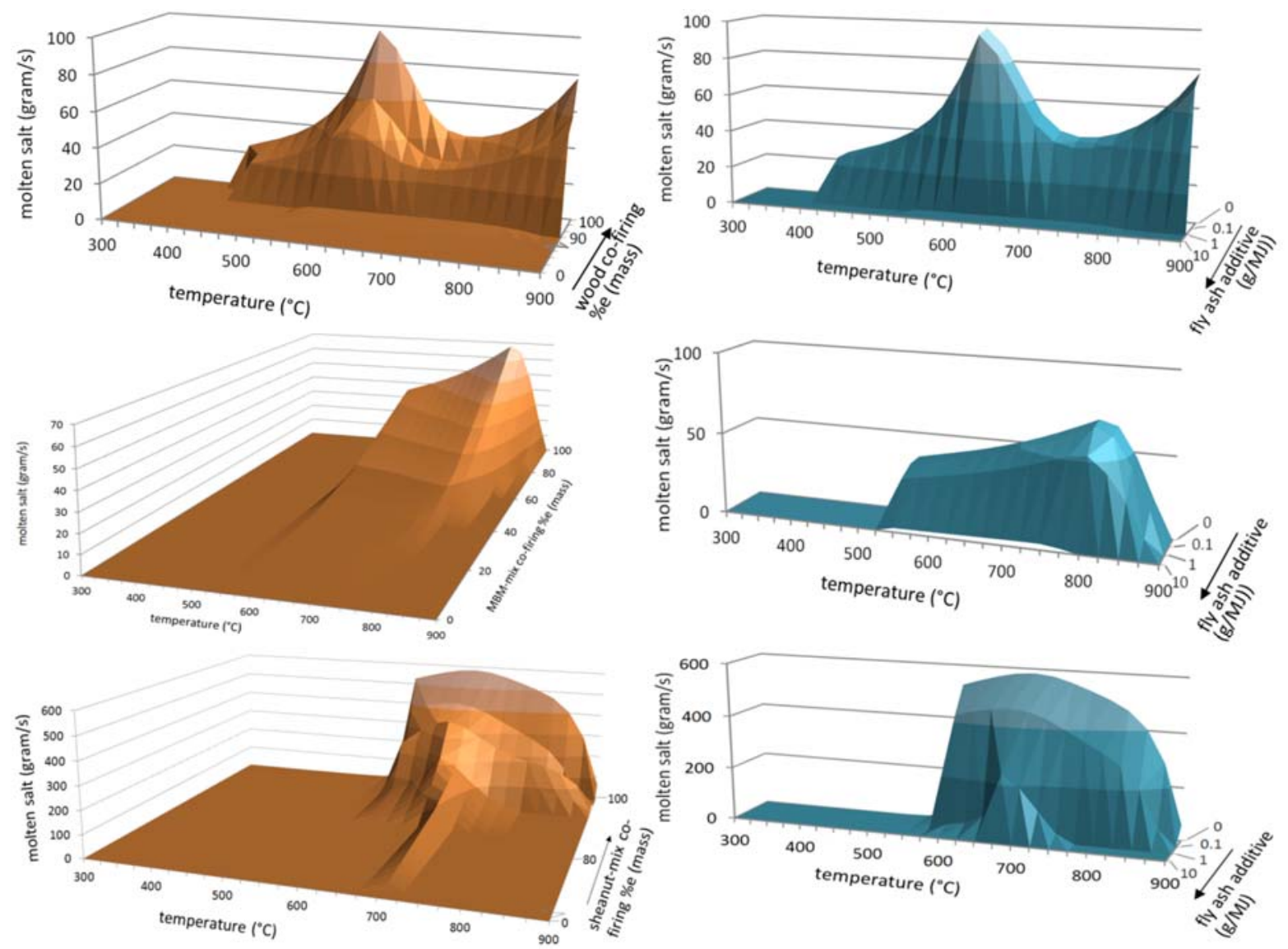

Figure 5.4 Equilibrium: molten $\mathrm{K}-\mathrm{Na}-\mathrm{SO}_{4}-\mathrm{Cl}$ salt as function of temperature and co-firing percentage (left); and as function of temperature and addition of coal fly ash (right). Top: (co-)firing wood; middle: (co-) firing MBM-mix; bottom: (co-) firing sheanut-mix.

Similar results have been produced for co-firing MBM-mix and sheanut-mix, see Figure 5.4 (left, middle and bottom). The amount of molten salt gradually increases with co-firing MBM-mix and most salt is present at $750-800{ }^{\circ} \mathrm{C}$; similarly, salt formation rapidly increases with co-firing $\geq$ $80 \%$ sheanut-mix while most salt is present at $650-700{ }^{\circ} \mathrm{C}$. The maximum amount of molten salt with firing only wood and only MBM-mix is of the same order of magnitude, contrary to firing only sheanut-mix where the amount of molten salt is about 6 times higher. Adding $10 \mathrm{~g} \mathrm{MJ}^{-1}$ of fly ash with firing only MBM-mix or sheanut-mix, results in a level of molten salt formation comparable to firing only coal.

Simulation results of addition of ammonium sulphate with firing only biomass are shown in Figure 5.5. Adding $1 \mathrm{~g} \mathrm{MJ}^{-1}$ of $\left(\mathrm{NH}_{4}\right)_{2} \mathrm{SO}_{4}$ with sheanut-mix, results in a level of molten salt formation comparable to firing only coal. This is also true for addition with firing only wood, but only up to $500{ }^{\circ} \mathrm{C}$; salt formation reduces at $500-750{ }^{\circ} \mathrm{C}$ with adding $0.1 \mathrm{~g} \mathrm{MJ}^{-1}$ of $\left(\mathrm{NH}_{4}\right)_{2} \mathrm{SO}_{4}$, but 
increased addition has no effect. Addition $>750{ }^{\circ} \mathrm{C}$ even leads to increased molten salt formation. Addition of $\left(\mathrm{NH}_{4}\right)_{2} \mathrm{SO}_{4}$ has no effect with firing MBM-mix.
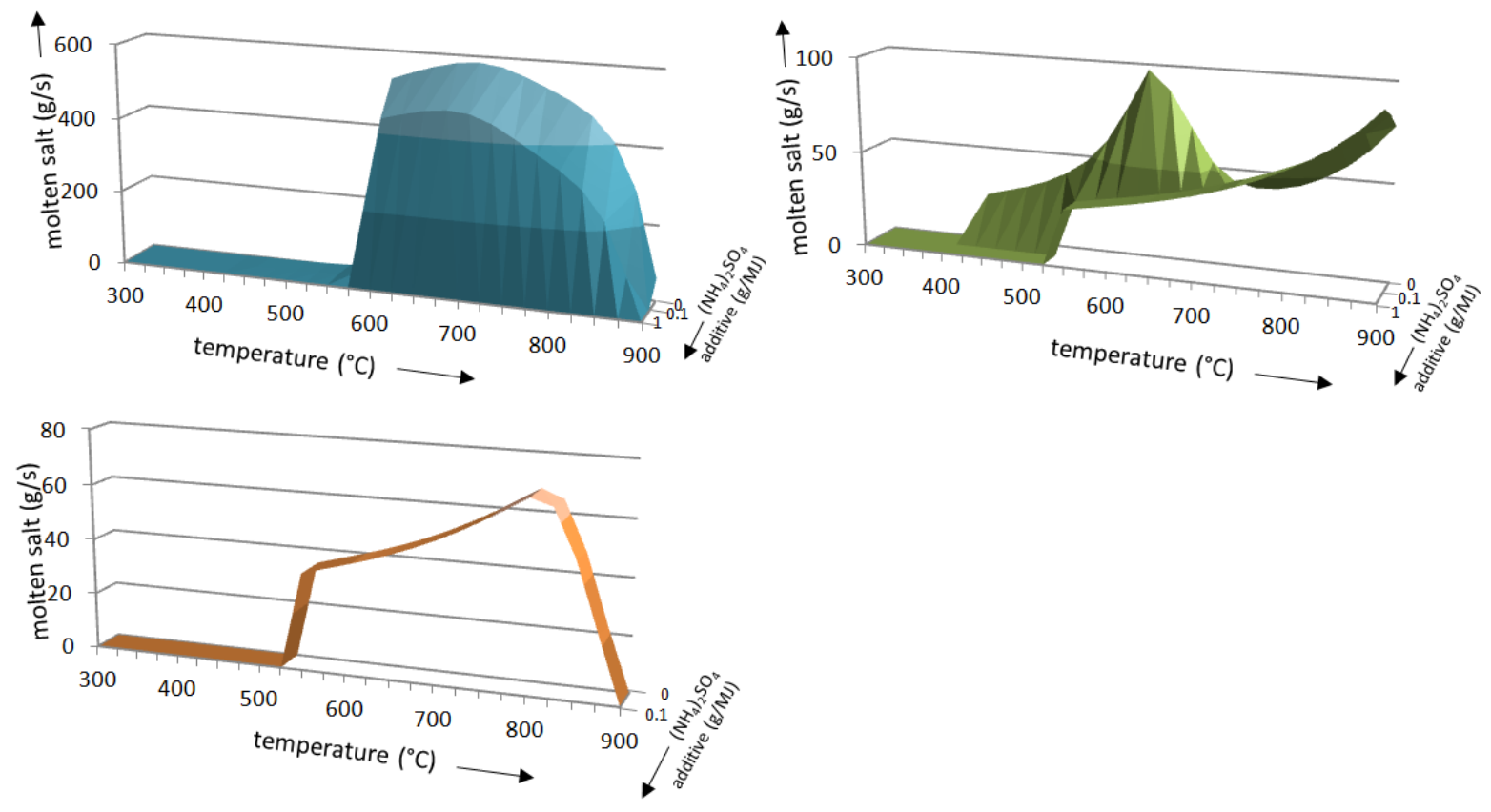

Figure 5.5 Equilibrium: molten $\mathrm{K}-\mathrm{Na}-\mathrm{SO}_{4}-\mathrm{Cl}$ salt as function of temperature and addition of ammonium sulphate with firing $100 \%$ sheanut-mix (left top), $100 \%$ wood (right top) and $100 \%$ MBM-mix (bottom).

\section{$5.4 \quad$ Discussion}

\subsubsection{Interaction of $\mathrm{K}$ and $\mathrm{Na}$ with ash and fly ash addition}

Both SEM and thermodynamic equilibrium results show that for co-firing percentages below $38 \%$ wood, $21 \%$ sheanut-mix or $18 \%$ MBM-mix, alkalis are associated with aluminosilicates. [16] also concluded this for co-firing MBM-mix and wood. In addition, [16] concluded that with co-firing of these fuels, the concentration of $\mathrm{K}, \mathrm{Ca}$ and $\mathrm{Mg}$ will increase. Our SEM results show that element concentrations vary per slag particle. $\mathrm{K}$ and $\mathrm{Na}$ concentrations correlate with each other and with the $\mathrm{Si}, \mathrm{Ca}$ and $\mathrm{Mg}$ concentration. This is observed for all fly ashes investigated with SEM. The $\mathrm{K}$ and $\mathrm{Na}$ concentration increase with increasing $\mathrm{Si}$ concentration and decreasing $\mathrm{Ca}$ and $\mathrm{Mg}$ concentration. This is in line with the findings of [17] who found an increased amount of water soluble $\mathrm{K}$ in fly ash (i.e. not in slag) with increased ratio of $\mathrm{K}: \mathrm{Si}$ in the fuel with co-combustion of coal and straw in an entrained flow reactor. Also, the $\mathrm{K}$ concentration increases with increasing $\mathrm{Na}$ concentration. An example of the correlation between the $\mathrm{K}$ concentration and the number $(\mathrm{Ca}+\mathrm{Mg}) / \mathrm{Si}$ for co-firing $38 \%$ wood is given in Figure 5.6, left. 

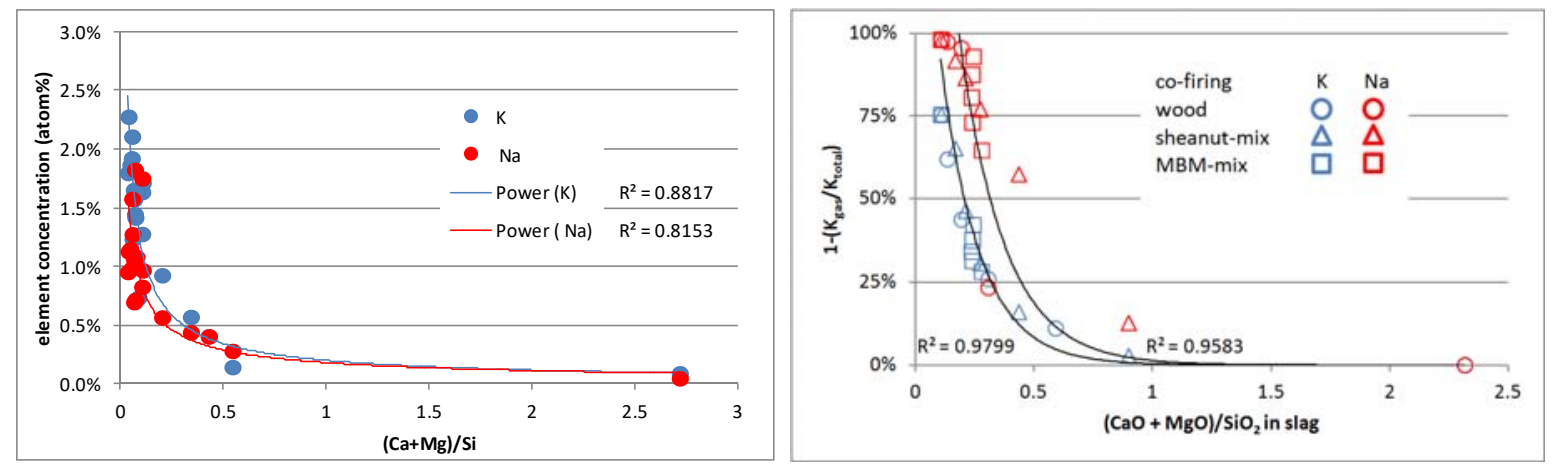

Figure 5.6 Left: Correlation between $(\mathrm{Ca}+\mathrm{Mg}) / \mathrm{Si}$ and $\mathrm{K}$ concentration in slag particles in PFAC from co-firing $38 \%$ wood (SEM results). Right: 1 - ratio of total $\mathrm{K}$ in the gas phase (equilibrium, $1,700{ }^{\circ} \mathrm{C}$, oxidizing conditions) versus the quotient of amount of available elements in the slag $(\mathrm{CaO}+\mathrm{MgO}) / \mathrm{SiO}_{2}$.

Thermodynamic calculations show that at high temperature $\left(1,700{ }^{\circ} \mathrm{C}\right), \mathrm{K}$ and $\mathrm{Na}$ will be in the gas phase to a larger extent if more of the much less volatile $\mathrm{Ca}$ and $\mathrm{Mg}$ are present in the slag (at both oxidizing and reducing conditions). A graph in which the percentage of total $\mathrm{K}$ in the gas phase (equilibrium, $1,700{ }^{\circ} \mathrm{C}$ ) versus the quotient $(\mathrm{CaO}+\mathrm{MgO}) / \mathrm{SiO}_{2}$ in the slag is plotted is given in Figure 5.6 (right), showing correlation between the two values. Similar correlations are found for $\mathrm{Na}$. (Note that while the quotient $(\mathrm{CaO}+\mathrm{MgO}) / \mathrm{SiO}_{2}$ in the slag is $>2$ for firing only wood, it is $<0.5$ for firing only MBM-mix. The reason is that $\mathrm{Ca}$ and $\mathrm{P}$ form $\mathrm{Ca}_{3}\left(\mathrm{PO}_{4}\right)_{2}(\mathrm{~s})$ rather than $\mathrm{Ca}$ as slag component when (co-)firing MBM-mix.)

Since at $1,700{ }^{\circ} \mathrm{C}$ alkalis are only present in gas and slag, Figure 5.6 (right) shows that more alkali dissolves in the slag if the ratio $(\mathrm{CaO}+\mathrm{MgO}) / \mathrm{SiO}_{2}$ is low. This observation is supported by the SEM-results on fly ash in Figure 5.6 (left).

A slag is an aluminosilicate network in which $\mathrm{Si}$ is a network former and $\mathrm{K}, \mathrm{Na}, \mathrm{Ca}$ and $\mathrm{Mg}$ are network modifiers. As more $\mathrm{Si}$ is present, more alkali (earth) elements can dissolve in the slag while alkali (earth) elements have to 'compete' with each other for a position in the network. This explains the observed correlations between alkali and silicon, and alkali and alkali earth element concentrations in the slag derived from SEM-results and with equilibrium modelling.

\subsubsection{Molten salt formation and addition of $\left(\mathrm{NH}_{4}\right)_{2} \mathrm{SO}_{4}$}

The formation of a molten $\mathrm{K}-\mathrm{Na}-\mathrm{SO}_{4}-\mathrm{Cl}$ salt depends on the temperature, the $\mathrm{S}$ to $\mathrm{Cl}$ ratio in the gas phase and the $\mathrm{K}$ to $\mathrm{Na}$ ratio (total $\mathrm{K}$ and $\mathrm{Na}$ present in the system). The calculation output allow for a parametric study regarding these ratios. Since a low K:Na ratio of 1 was not covered 
by the assessed co-firing cases, $\mathrm{K}: \mathrm{Na}=1$ was simulated by artificially adding $\mathrm{Na}$ to MBM-mix in the calculations. Figure 5.7 shows the results of this parametric study and in equilibrium, a molten salt forms with $\mathrm{S}: \mathrm{Cl} \leq 1.2$ if $\mathrm{K}: \mathrm{Na}>10$, with $\mathrm{S}: \mathrm{Cl} \leq 2.1$ if $2.4<\mathrm{K}: \mathrm{Na}<4.7$ and with $\mathrm{S}: \mathrm{Cl} \leq$ 3.5 if $\mathrm{K}: \mathrm{Na}=1$. The $\mathrm{S}: \mathrm{Cl}$ ratio decreases with increasing biomass co-firing rate. The $\mathrm{K}$ to $\mathrm{Na}$ ratio is dependent on the fuel type and is highest for sheanut-mix and lowest for MBM-mix.

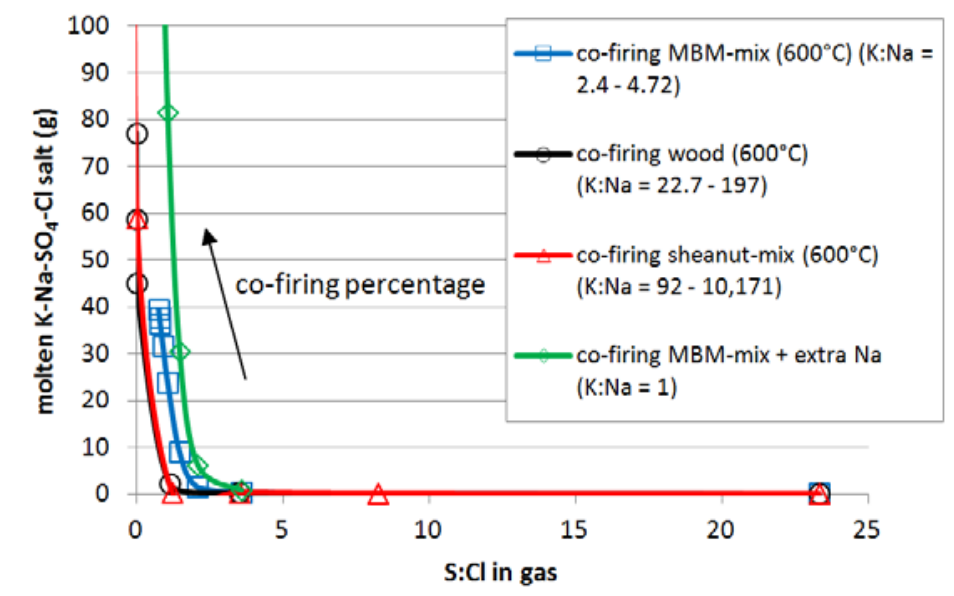

Figure 5.7 Formation of molten $\mathrm{K}-\mathrm{Na}-\mathrm{SO}_{4}-\mathrm{Cl}$ salt with different $\mathrm{S}$ to $\mathrm{Cl}$ and $\mathrm{K}$ to $\mathrm{Na}$ ratios.

Thermodynamic calculations show that with adding $0.1 \mathrm{~g} / \mathrm{MJ}\left(\mathrm{NH}_{4}\right)_{2} \mathrm{SO}_{4}$ to $100 \%$ sheanut-mix combustion gas, $\mathrm{K}_{2} \mathrm{SO}_{4}(\mathrm{~s})$ is formed at the expense of $\mathrm{K}_{2} \mathrm{SO}_{4}$ and $\mathrm{K}_{2} \mathrm{CO}_{3}$ as molten salt constituents, see Figure 5.8 (left). The amount of $\mathrm{KCl}$ in molten salt, $\mathrm{KCl}(\mathrm{g})$ and $\mathrm{KOH}(\mathrm{g})$ stays about the same. With adding $1 \mathrm{~g} / \mathrm{MJ}$ ammonium sulphate, almost no molten salt and $\mathrm{KOH}(\mathrm{g})$ is left, while the amount of $\mathrm{KCl}(\mathrm{g})$ at $900{ }^{\circ} \mathrm{C}$ has decreased with about $60 \%$ (compared to adding no ammonium sulphate). In addition, $\mathrm{HCl}(\mathrm{g})$ is formed, see Appendix 5.D. 

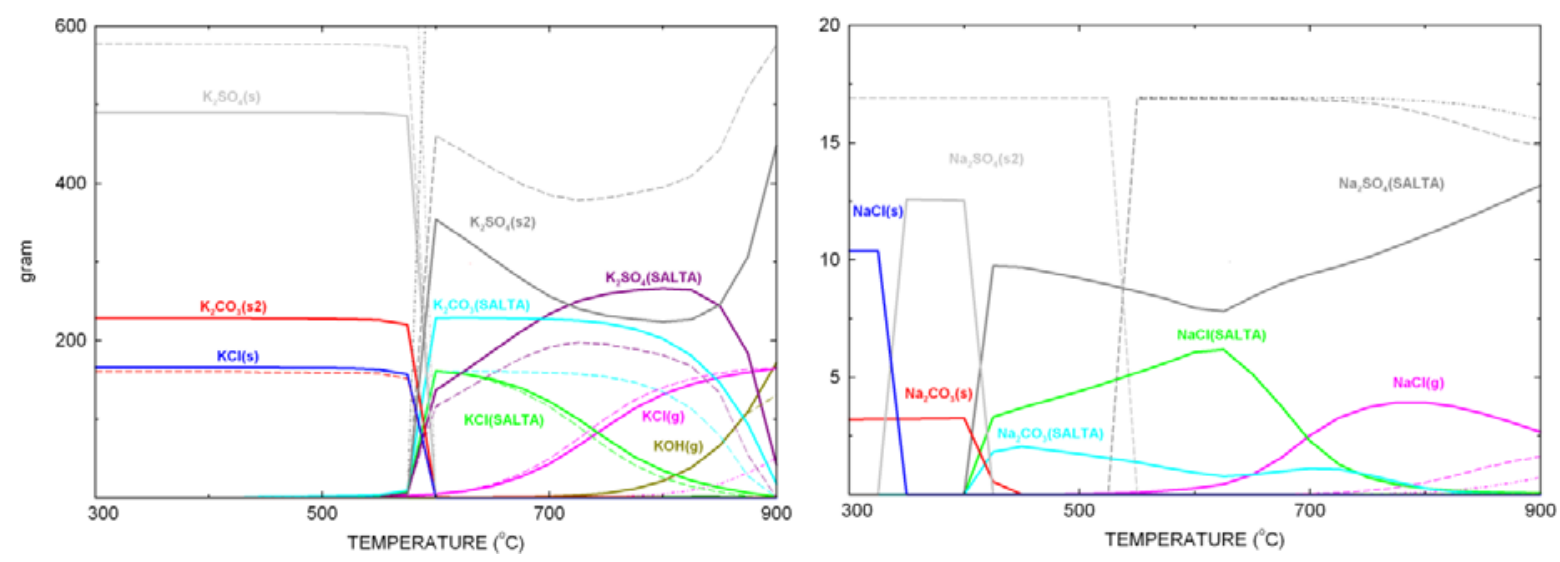

Figure 5.8 Thermodynamic equilibrium diagrams with different amounts of $\left(\mathrm{NH}_{4}\right)_{2} \mathrm{SO}_{4}$ addition ( $\quad 0 \mathrm{~g} \mathrm{MJ}^{-1}$, - - $0.1 \mathrm{~g} \mathrm{MJ}^{-1}$ and -..- $1 \mathrm{~g} \mathrm{MJ}^{-1}$ addition). Left: K-containing compounds, $100 \%$ sheanut-mix. Right: Na-containing compounds, $100 \%$ wood. The designation "SALTA" indicates that it is a molten salt constituent.

With adding $0.1 \mathrm{~g} / \mathrm{MJ}$ ammonium sulphate to $100 \%$ wood, also more $\mathrm{K}_{2} \mathrm{SO}_{4}(\mathrm{~s})$ is formed at the expense of $\mathrm{K}_{2} \mathrm{SO}_{4}, \mathrm{KCl}$ and $\mathrm{K}_{2} \mathrm{CO}_{3}$ as molten salt constituents and fouling reduces, although the reduction of $\mathrm{K}_{2} \mathrm{SO}_{4}$ as molten salt constituent is limited to $700{ }^{\circ} \mathrm{C}$. Above $700{ }^{\circ} \mathrm{C}$, ammonium sulphate addition leads to an increase of $\mathrm{K}_{2} \mathrm{SO}_{4}$ as molten salt constituent (see Appendix 5.D). The amount of gaseous $\mathrm{KCl}$ reduces and $\mathrm{HCl}$ is (thermodynamically) stable in stead. In addition, above $700{ }^{\circ} \mathrm{C}$, ammonium sulphate addition leads to increased formation of $\mathrm{Na}_{2} \mathrm{SO}_{4}$ as molten salt constituent at the expense of $\mathrm{NaCl}(\mathrm{g})$, see Figure 5.8.

MBM-mix is already a sulphur-rich fuel and addition of ammonium sulphate does not change the chemical composition of the molten salt. All molten salt is $\mathrm{K}_{2} \mathrm{SO}_{4}$ and $\mathrm{Na}_{2} \mathrm{SO}_{4}$ (see Appendix 5.D) and since there is no chloride to replace in the salt, fouling is not reduced.

From the evaluation of ammonium sulphate addition (i.e. increasing the $\mathrm{S}$ to $\mathrm{Cl}$ ratio) with $\mathrm{Na}$ and almost no $\mathrm{Na}$ present, the influence of $\mathrm{S}: \mathrm{Cl}$ is explained. In case relatively little $\mathrm{Na}$ is present (Na:K is low), $\mathrm{K}_{2} \mathrm{SO}_{4}(\mathrm{~s})$ is more thermodynamically stable than $\mathrm{K}_{2} \mathrm{SO}_{4}, \mathrm{~K}_{2} \mathrm{CO}_{3}$ and $\mathrm{KCl}$ as molten salt constituent if $\mathrm{S}: \mathrm{Cl}$ is sufficiently high. Similarly, with increased $\mathrm{S}: \mathrm{Cl}, \mathrm{Na}_{2} \mathrm{SO}_{4}(\mathrm{~s})$ is more stable than $\mathrm{Na}_{2} \mathrm{SO}_{4}, \mathrm{Na}_{2} \mathrm{CO}_{3}$ and $\mathrm{NaCl}$ as salt constituent, but only below approximately $530{ }^{\circ} \mathrm{C}$. Above this temperature, only molten salt is stable and not $\mathrm{Na}_{2} \mathrm{SO}_{4}(\mathrm{~s})$; with increased $\mathrm{S}: \mathrm{Cl}, \mathrm{Na}_{2} \mathrm{SO}_{4}$ as salt constituent forms rather than $\mathrm{Na}_{2} \mathrm{CO}_{3}$ and $\mathrm{NaCl}$. Further increase of $\mathrm{S}: \mathrm{Cl}$ will induce no change. In case both $\mathrm{Na}$ and $\mathrm{K}$ are present (Na:K increases), a molten $\mathrm{K}-\mathrm{Na}-\mathrm{SO}_{4}$ salt is stable with increased $\mathrm{S}: \mathrm{Cl}$ ratio in stead of mostly $\mathrm{K}_{2} \mathrm{SO}_{4}(\mathrm{~s})$ with low $\mathrm{Na}: \mathrm{K}$.

A suggestion for further research is to investigate deposits from boilers formed under similar conditions as taken for the modelling. With a comparison of the results, the mechanisms of 
formation of salts can be verified. Moreover, the effect of blending and therewith the actual implementation of fly ash and ammonium sulphate can be investigated.

\subsection{Conclusions}

In (converted) coal-fired boilers, the flue gas temperature is sufficiently high so that a slag phase can form that allows for gaseous alkali dissolution. Alkalis are thereby removed from the gas phase to certain extent. In dedicated biomass boilers flue gas temperatures are lower and slag formation is limited: more alkalis will remain gaseous and aerosols will form when the flue gases cool down. Alkali dissolution in the slag (so the extent of alkali removal from the gas phase) decreases with increasing $(\mathrm{CaO}+\mathrm{MgO})$ to $\mathrm{SiO}_{2}$ ratio in the slag which, in its turn, increases with biomass co-firing rate. Thermodynamic calculations show that addition of $1-10 \mathrm{~g} / \mathrm{MJ}$ coal fly ash can mitigate fouling with firing only wood, MBM-mix or sheanut-mix.

Formation of molten alkali salts depends on both the $S$ to $\mathrm{Cl}$ ratio and the $\mathrm{K}$ to $\mathrm{Na}$ ratio: in equilibrium, a molten salt forms with $\mathrm{S}: \mathrm{Cl} \leq 1.2$ if $\mathrm{K}: \mathrm{Na}>10$, with $\mathrm{S}: \mathrm{Cl} \leq 2.1$ if $2.4<\mathrm{K}: \mathrm{Na}<4.7$ and with $\mathrm{S}: \mathrm{Cl} \leq 3.5$ if $\mathrm{K}: \mathrm{Na}=1$. The $\mathrm{S}: \mathrm{Cl}$ ratio decreases with increasing biomass co-firing rate. Thermodynamic calculations show that addition of $1 \mathrm{~g} / \mathrm{MJ}$ ammonium sulphate can fully mitigate fouling with firing sheanut-mix that contains relatively little $\mathrm{Na}$, and can lower fouling with firing wood up to a flue gas temperature of $700{ }^{\circ} \mathrm{C}$; however, it will increase fouling with wood above $700^{\circ} \mathrm{C}$. Fouling with firing MBM-mix does not change with adding ammonium sulphate since it is already a sulphur-rich fuel mix.

It is noted that the dosing rates of additives in this chapter are calculated using thermodynamic equilibrium and assuming ideal mixing. In practise, mixing may be limited and non-equilibrium conditions apply, especially for lower temperature. Although the drawbacks of the equilibrium approach have been accounted for, e.g. by applying an availability factor, the equilibrium results present a limiting case. In practise, dosing rates will be equal or higher, especially for ammonium sulphate. Furthermore, it is recommended to perform full-scale testing to verify the salt formation mechanisms described in this chapter and to investigate the optimal locations in the boiler for adding additives.

\section{References}

[1] Miles Sr TR, Miles Jr TR, Baxter LL, Bryers RW, Jenkins BM, Oden LL. Boiler deposits from firing biomass fuel. Biomass Bioenergy, 1996, 10, 125-28.

[2] Stam AF, Haasnoot K, Brem G. Superheater fouling in a BFB boiler firing wood-based fuel blends. Fuel, 2014, 135, 322-31. 
[3] Andersen KH. Deposit Formation during Coal-Straw Co-Combustion in a Utility PF-Boiler. PhD Thesis, Technical University of Denmark, 1998.

[4] Damoe AJ, Wu H, Frandsen FJ, Glarborg P, Sander B. Impact of coal fly ash addition on combustion aerosols (PM2.5) from full-scale suspension-firing of pulverized wood. Energy Fuels, 2014, 28, 3217-23.

[5] Steenari B-M, Lindqvist O. High temperature reactions of straw ash and the anti-sintering additives kaolin and dolominte. Biomass Bioenergy, 1998, 14, 67-76.

[6] Henderson P, Sakálos P, Pettersson R, Andersson C, Högberg J. Reducing superheater corrosion in wood-fired boilers. Materials Corrosion, 2006, 57, 128-34.

[7] Tobiasen L, Skytte R, Storm Pedersen I, Thaaning Pedersen S, Lindberg MA. Deposit characteristic after injection of additives to a Danish straw-fired suspension boiler. Fuel Proc Technol, 2007, 88, 1108-17.

[8] Bale CW, Chartrand P, Degterov SA, Eriksson G, Hack K, Ben Mahfoud R, et al. FactSage Thermochemical Software and Databases. CALPHAD, 2002, 26, 189-228.

[9] Becidan M, Sørum L, Frandsen F, Pedersen AJ. Corrosion is waste-fired boilers: A thermodynamic study. Fuel, 2009, 88, 595-604.

[10] Vassilev SV, Menendez R, Alvarez D, Diaz-Somoanob M, Martinez-Tarazonab MR. Phasemineral and chemical composition of coal fly ashes as a basis for their multicomponent utilization. 1. Characterization of feed coals and fly ashes. Fuel, 2003, 82,1793-811.

[11] Zevenhoven-Onderwater M. Ash-Forming Matter in Biomass Fuels [dissertation]. Turku: Åbo Akademi; 2001. ISBN 9521208139.

[12] Doshi V, Vuthaluru HB, Korbee R, Kiel JHA. Development of a modelling approach to predict ash formation during co-firing of coal and biomas. Fuel Process Technol, 2009, 90, 1148-56.

[13] Nutalapati D, Gupta R, Moghtaderi B, Wall TF. Assessing slagging and fouling during biomass combustion: A thermodynamic approach allowing for alkali/ash reactions. Fuel Proces Technol, 2007, 88, 1044-52.

[14] Tortosa Masiá AA, Buhre BJP, Gupta RP, Wall TF. Characterising ash of biomass and waste. Fuel Proc Technol, 2007, 88, 1071-88. 
[15] Sarabèr A. Fly ash from coal and biomass for use in concrete. Origin, properties and performance. PhD thesis, TU Delft, 2017.

[16] Sarabèr AJ. Co-combustion and its effects on fly ash quality; real-scale experiments. Fuel Proc Technol, 2014, 124, 68-82.

[17] Zheng Y, Jensen PA, Jensen AD. Appendix D: Potassium capture by kaolin and fly ash powder in an entrained flow reactor. In: Ash transformation in suspension fired boilers co-firing coal and straw. Final report, PSO-Eltra 4766, Technical University of Denmark, Department of Chemical Engineering. CHEC, No. R0803, 2009.

This Chapter is based on the earlier published article:

Stam AF, Brem G. Fouling in coal-fired boilers: Biomass co-firing, full conversions and use of additives - A thermodynamic approach. Fuel, 2019, 239, 1274-83. 

FUEL BLENDS

\subsection{Introduction}

Fouling in BFB (Bubbling Fluidized Bed) boilers is a well-known problem related to firing biomass and can reduce economically viable operation of the plant. Not only does it decrease plant efficiency by stack losses, it also can cause downtime by clogging. Moreover, clogging can lead to over pressure in the boiler, which on its turn can lead to fire in the fuel feeding systems. On the longer term, fouling can lead to boiler damage by erosion (caused by increased flue gas velocities), and high-temperature corrosion by (Cl-rich) molten salt deposits that generally cause highest corrosion rates. In load following plants balancing the grid fed by solar and wind power, fouling and corrosion may be induced by ramping production up and down, implying higher investments or higher operation and maintenance costs [1].

Fouling is investigated in a $28 \mathrm{MW}_{\mathrm{el}}$ BFB boiler operated by RWE Essent in Cuijk, The Netherlands. It had been fired with wood chips for about 10 years yielding relatively little fouling which was mainly confined to one of the economizer bundles, notably ECO 3 (see Figure 6.1). This economizer consists of finned tubes with little spacing (ca. $2 \mathrm{~cm}$ between the fins and ca. 6 $\mathrm{cm}$ between the tubes), easily leading to clogging.

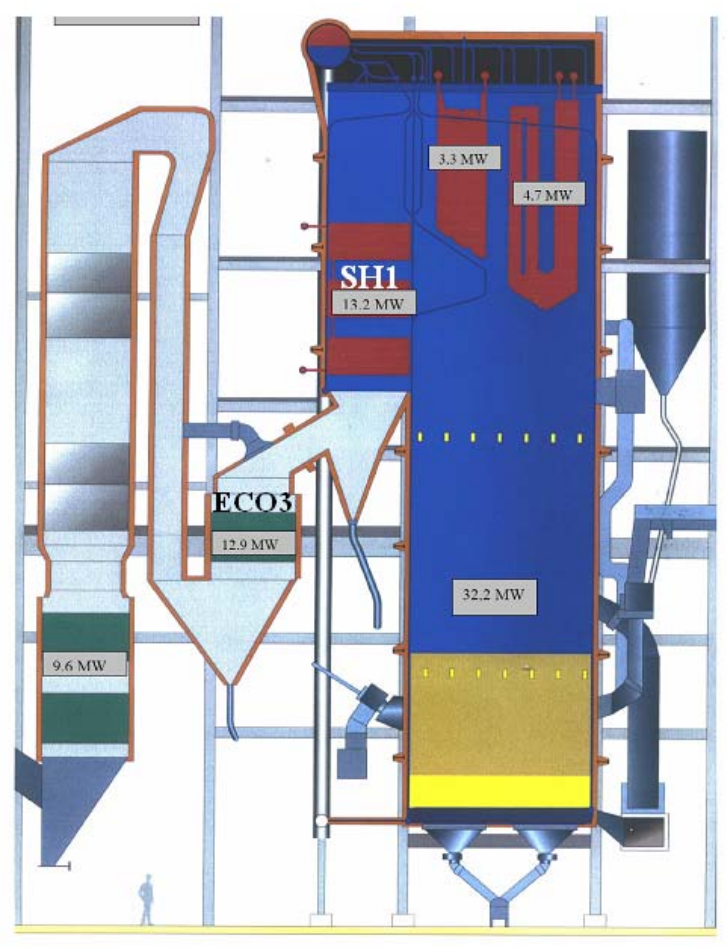

Figure 6.128 MWel BFB boiler operated by RWE Essent in Cuijk, The Netherlands. 
When the fuel mix was changed from wood chips (this is referred to as 'test 0 ') to a mix of wood and compost overflow during test period 1, the superheater bundles (notably SH 1) fouled heavily, resulting in a forced shut down of the boiler. A matured deposit was sampled and investigated with SEM. Two different fuel blends were then fired for two weeks each, during test periods 2 and 3 . The deposits were sampled in the boiler with an air cooled probe and were investigated with SEM. Additional thermodynamic calculations were carried out.

The objectives of this chapter are to explain the fouling behaviour of $\mathrm{SH} 1$ in the RWE Essent BFB boiler, to distinguish the fouling propensity between different fuel blends, and to relate this behaviour and propensity to the different fuel blend compositions, as well as the local conditions at the fouled bundles. Based on the explained behaviour, a prediction will be made using thermodynamic modelling for fouling propensities that will be compared with the measurement results. Prediction will allow the operators to select a commercial attractive fuel blend with acceptable fouling propensity.

Real scale results of fouling in a BFB boiler firing woody fuels have been reported in literature. Miles et al. [2] investigated deposits collected in a $27 \mathrm{MW}_{\mathrm{el}}$ BFB boiler firing urban wood and agricultural residues (the blend composition is comparable to the composition of the blends in our research used in test 0 and 3 , but the individual fuels in Miles et al. differ from the fuels in our test). The superheater deposits were wedge-shaped, and formed perpendicular to the flow, and were solid but granular in nature. Main constituents in the deposit were $\mathrm{CaO}(19-26 \%), \mathrm{K}_{2} \mathrm{O}(17-$ $26 \%), \mathrm{SO}_{3}(13-18 \%), \mathrm{SiO}_{2}(9-15 \%)$ and $\mathrm{Cl}(10-14 \%)$. Peltola et al. [3] sampled deposits with air cooled probes in a $66 \mathrm{MW}_{\text {th }}$ BFB combustor using wood chips, bark and saw dust as main fuel, mixed with green forest residue, chipboard reject and peat. Probes were exposed for $5-78$ hours at flue gas temperatures of $850{ }^{\circ} \mathrm{C}$ and $750{ }^{\circ} \mathrm{C}$ (probe metal temperatures are not indicated). The deposit closest to the (metal) surface contained $\mathrm{K}, \mathrm{S}$ and $\mathrm{Ca}$ concentrations higher than in average fly ash as well as some $\mathrm{Cl}$ which was unevenly distributed (even $\mathrm{KCl}$ crystals were observed). Highest deposition rates were observed with firing chipboard reject, followed by chipboard / peat mixture and the mixture of bark, saw dust and wood chips. Lowest deposition rates were observed with forest residue, which was contrary to earlier experience. The fouling rate did not correlate with the fuel ash content. Also Skrifvars et al. [4] gathered deposits with probes. They did their experiments in a $105 \mathrm{MW}_{\text {th }}$ BFB boiler fired with wood chips resulting in the highest deposition rates, and with wood chips partly (15\%) replaced by coal and with forest residue, both leading to low deposition rates. 


\subsection{Experimental and modelling}

\subsubsection{Fuels and operation}

The fuel blends of the four test periods are shown in Table 6.1; the composition of the individual fuels and blends are given in Tables 6.2 and 6.3. All fuels were sourced from nearby locations. A broad range of fuels was used in the test 1 period: wood, compost overflow (coarse woody materials unsuited for compost fermentation), roadside grass (resulting from regular maintenance along roads) and paper sludge. The roadside grass was left out during test 2 while only wood based fuels were used in test 3 .

Table 6.1 Fuel blends. Shares on basis of mass input (a.r.).

\begin{tabular}{lllll}
\hline & test 0 & test 1 & test 2 & test 3 \\
\hline wood chips & $100 \%$ & & $5.6 \%$ & $7.6 \%$ \\
demolition wood & & $38.7 \%$ & & $39.1 \%$ \\
wood cuttings & & $38.6 \%$ & $68.3 \%$ & $53.3 \%$ \\
compost overflow & & $6.2 \%$ & $8.6 \%$ & \\
paper sludge & & $7.3 \%$ & $17.6 \%$ & \\
roadside grass & & $9.2 \%$ & & \\
\hline
\end{tabular}


Table 6.2 Fuel composition. Concentrations on basis of mass (a.r.).

\begin{tabular}{|c|c|c|c|c|c|c|c|c|c|c|}
\hline & test 0 & test 1 & test $1 / 2$ & test $1 / 2$ & test $1 / 2$ & test 1 & test 2 & test 3 & test 3 & test 3 \\
\hline & $\begin{array}{l}\text { wood } \\
\text { chips }\end{array}$ & $\begin{array}{l}\text { demolition } \\
\text { wood }\end{array}$ & $\begin{array}{l}\text { wood } \\
\text { cuttings }\end{array}$ & $\begin{array}{l}\text { compost } \\
\text { overflow }\end{array}$ & $\begin{array}{l}\text { paper } \\
\text { sludge }\end{array}$ & $\begin{array}{l}\text { roadside } \\
\text { grass }\end{array}$ & $\begin{array}{l}\text { wood } \\
\text { chips }\end{array}$ & $\begin{array}{l}\text { wood } \\
\text { chips }\end{array}$ & $\begin{array}{l}\text { demolition } \\
\text { wood }\end{array}$ & $\begin{array}{l}\text { wood } \\
\text { cuttings }\end{array}$ \\
\hline $\mathrm{C}(\%)$ & 48.2 & 50.9 & 47.8 & 40.3 & 33.6 & 49.1 & 48.10 & 39.4 & 36.7 & 41.2 \\
\hline $\mathrm{H}(\%)$ & 6 & 6.2 & 5.9 & 4.9 & 4.0 & 5.3 & 6.00 & 5.3 & 4.9 & 4.8 \\
\hline $\mathrm{N}(\%)$ & 0.3 & 1.0 & 0.7 & 0.6 & 0.3 & 0.9 & 0.33 & 1.6 & 2.8 & 1.3 \\
\hline $\mathrm{S}(\%)$ & 0.04 & 0.71 & 0.02 & 0.07 & 0.06 & 1.5 & 0.01 & 0.05 & 0.09 & 0.10 \\
\hline $\mathrm{O}(\%)$ & 42.7 & 39.4 & 42.1 & 42.3 & 35.0 & 19.3 & 44.83 & 49.9 & 52.9 & 48.4 \\
\hline water (\%) & 39.5 & 40.7 & 42.2 & 42.9 & 54.8 & 30.0 & 27.10 & 45.3 & 25.2 & 39.9 \\
\hline ash (\%) & 1.9 & 1.9 & 3.4 & 11.7 & 26.9 & 23.9 & 0.70 & 3.7 & 2.7 & 3.9 \\
\hline LHV $(\mathrm{MJ} / \mathrm{kg})$ & 9.9 & 9.9 & 9.8 & 9.3 & 4.7 & 9.8 & 12.50 & 8.6 & 12.1 & 9.0 \\
\hline $\mathrm{Al}(\%)$ & 0.05 & 0.11 & 0.04 & 0.0 & 0.89 & 0.38 & 0.01 & 0.03 & 0.09 & 0.08 \\
\hline $\mathrm{Ca}(\%)$ & 0.46 & 0.53 & 0.66 & 5.0 & 13.2 & 1.1 & 0.15 & 0.95 & 0.48 & 0.93 \\
\hline $\mathrm{Cl}(\%)$ & 0.026 & 0.001 & 0.068 & 0.18 & 0.14 & 0.1 & 0.027 & 0.019 & 0.135 & 0.042 \\
\hline $\mathrm{Fe}(\%)$ & 0.06 & 0.07 & 0.03 & 0.0 & 0.16 & 0.26 & 0.02 & 0.03 & 0.11 & 0.09 \\
\hline $\mathrm{K}(\%)$ & 0.23 & 0.01 & 0.26 & 0.0 & 0.03 & 0.24 & 0.07 & 0.24 & 0.07 & 0.27 \\
\hline $\mathrm{Mg}(\%)$ & 0.05 & 0.03 & 0.06 & 0.0 & 0.20 & 0.14 & 0.03 & 0.09 & 0.06 & 0.09 \\
\hline $\mathrm{Na}(\%)$ & 0.02 & 0.02 & 0.05 & 0.03 & 0.11 & 0.12 & 0.06 & 0.05 & 0.08 & 0.06 \\
\hline $\mathrm{P}(\%)$ & 0.04 & 0.01 & 0.05 & 0.0 & 0.03 & 0.13 & 0.01 & 0.03 & 0.01 & 0.06 \\
\hline Si (\%) & 0.16 & 0.20 & 0.52 & 1.6 & 0.76 & 0.04 & 0.02 & 0.37 & 0.39 & 0.50 \\
\hline $\mathrm{Ti}(\%)$ & 0.005 & 0.001 & 0.001 & 0.0 & 0.006 & 0.001 & 0.0 & 0.0 & 0.01 & 0.001 \\
\hline
\end{tabular}


Table 6.3 Fuel blends composition. Concentrations on basis of mass (a.r.).

\begin{tabular}{|c|c|c|c|c|}
\hline & test 0 & test 1 & test 2 & test 3 \\
\hline C (\%) & 48.2 & 47.6 & 44.8 & 39.3 \\
\hline $\mathrm{H}(\%)$ & 6 & 5.7 & 5.5 & 4.9 \\
\hline $\mathrm{N}(\%)$ & 0.3 & 0.78 & 0.6 & 1.9 \\
\hline $\mathrm{S}(\%)$ & 0.04 & 0.43 & 0.09 & 0.09 \\
\hline $\mathrm{O}(\%)$ & 42.7 & 38.4 & 60.0 & 50.3 \\
\hline total water $(\%)$ & 39.5 & 41.5 & 43.7 & 34.6 \\
\hline ash (\%) & 1.9 & 7.0 & 7.8 & 3.4 \\
\hline LHV (MJ/kg) & 9.9 & 9.4 & 9.0 & 10.2 \\
\hline $\mathrm{Al}(\%)$ & 0.050 & 0.16 & 0.16 & 0.084 \\
\hline $\mathrm{Ca}(\%)$ & 0.46 & 1.83 & 3.10 & 0.75 \\
\hline $\mathrm{Cl}(\%)$ & 0.026 & 0.06 & 0.08 & 0.08 \\
\hline $\mathrm{Fe}(\%)$ & 0.06 & 0.07 & 0.05 & 0.09 \\
\hline $\mathrm{K}(\%)$ & 0.23 & 0.13 & 0.18 & 0.19 \\
\hline $\operatorname{Mg}(\%)$ & 0.05 & 0.06 & 0.08 & 0.08 \\
\hline $\mathrm{Na}(\%)$ & 0.02 & 0.05 & 0.05 & 0.07 \\
\hline $\mathrm{P}(\%)$ & 0.04 & 0.03 & 0.04 & 0.04 \\
\hline Si $(\%)$ & 0.16 & 0.44 & 0.62 & 0.45 \\
\hline $\mathrm{Ti}(\%)$ & 0.005 & 0.001 & 0.002 & 0.004 \\
\hline
\end{tabular}

The design metal temperature of the superheater bundles $(\mathrm{SH} 1)$ is $420{ }^{\circ} \mathrm{C}$ and the design flue gas temperature at the bundles is $650{ }^{\circ} \mathrm{C}$. The bed temperature is $880-890{ }^{\circ} \mathrm{C}$ while this temperature was lowered to $800-820^{\circ} \mathrm{C}$ in the first week of test 2. Test 0 reflects the normal operation with firing only wood chips during several years. The period of test 1 lasted for $>6$ weeks, while test 2 and test 3 both lasted for two weeks.

\subsubsection{Air Cooled Probe Set-up}

An air cooled probe was used to collect deposit samples. The set-up of the probe is shown in Figure 6.2 (left). The probe protrudes the boiler wall for about $1.5 \mathrm{~m}$ through a specially made hatch at a location chosen in such a way that the probe tip is located close $(<1 \mathrm{~m})$ to the SH1 bundle. The tip of the probe is shown in Figure 6.2 (right) exhibiting the detachable fouling ring (outer diameter is $38 \mathrm{~mm}$ ). The temperature of the fouling ring is controlled and the ring holds two thermocouples located at different distances from the metal surface, so that the surface temperature can be calculated by extrapolation. This calculated surface temperature is input for a PID controller, steering the hydraulic control valve for the cooling air. The set value was $420{ }^{\circ} \mathrm{C}$ 
which is the (design) metal temperature of superheater SH1. The probe has been exposed for 6 and 7 days (with cleaning in between) during test 2 and for 11 days during test 3 .

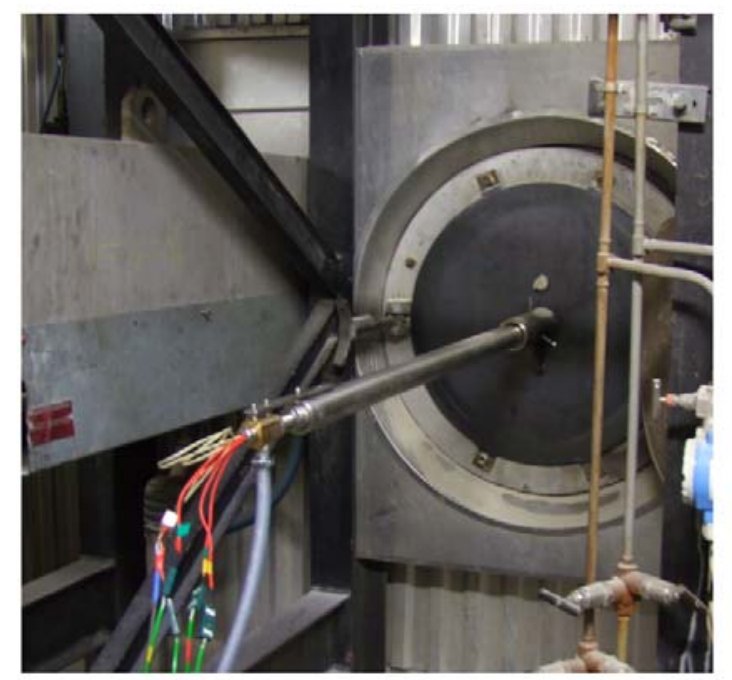

Figure 6.2 Set up of air cooled probe (left) and probe tip (right).

\subsubsection{Samples, preparation and microscopic investigations}

A sample was taken from the deposit on the superheater tubes (SH1) after the first test period (test1). The latter was a fully developed, matured deposit and was examined by microscope. The sample had broken in two pieces which are designated as 'part A' and 'part B', see Figure 6.3.
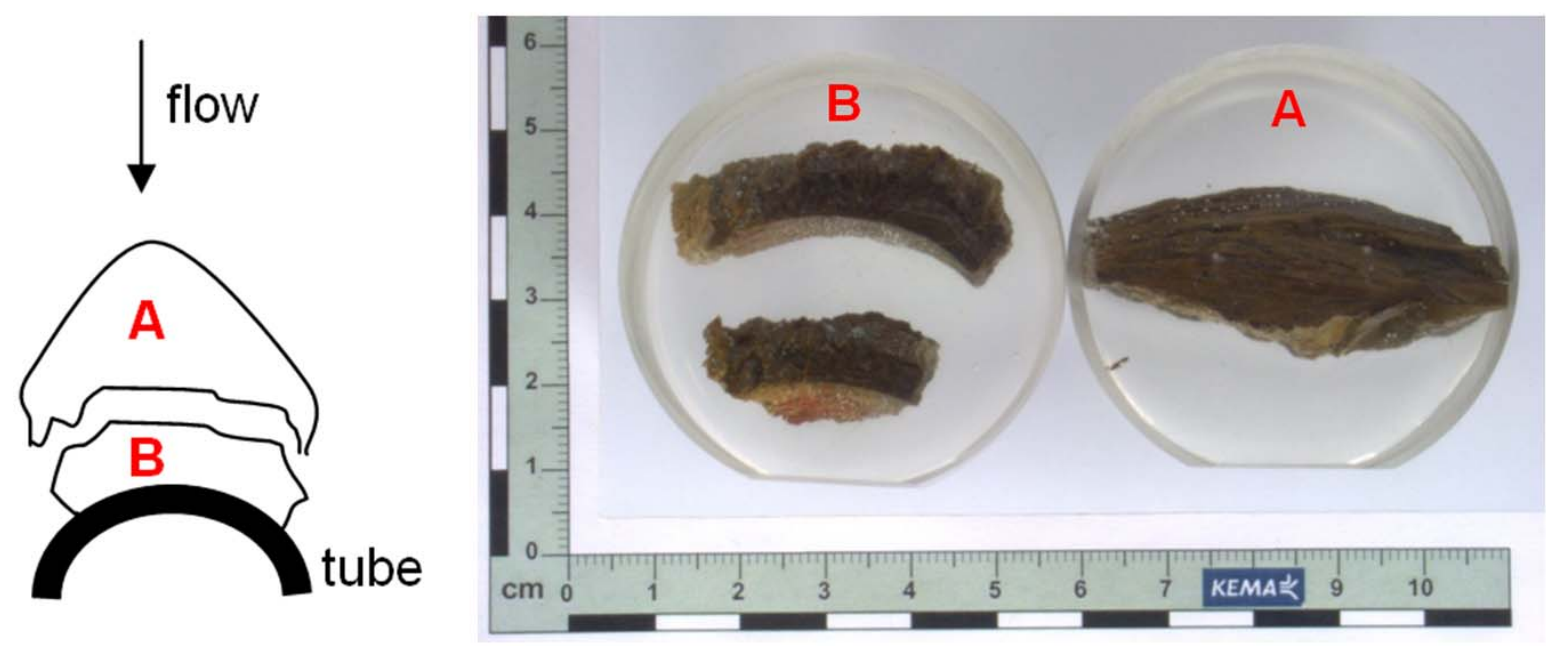

Figure 6.3 Sample gathered from superheater tube during test 1. 
The samples in tests 2 and 3 were collected using the air cooled probe. After the first week of test 2 , a ring with attached deposit could not be retrieved (the assembly with the different rings with deposit is shown in Figure 6.4 (left)). Nevertheless, the deposit came off in two parts: the part directly on the metal surface and a 'grain-like' deposit on top of that (the latter can be seen in Figure 6.4 (right)). Rings with attached deposit were retrieved both after the second week of test 2 , and after test 3 . The bulk of the deposits were formed on the upstream side of the probe.

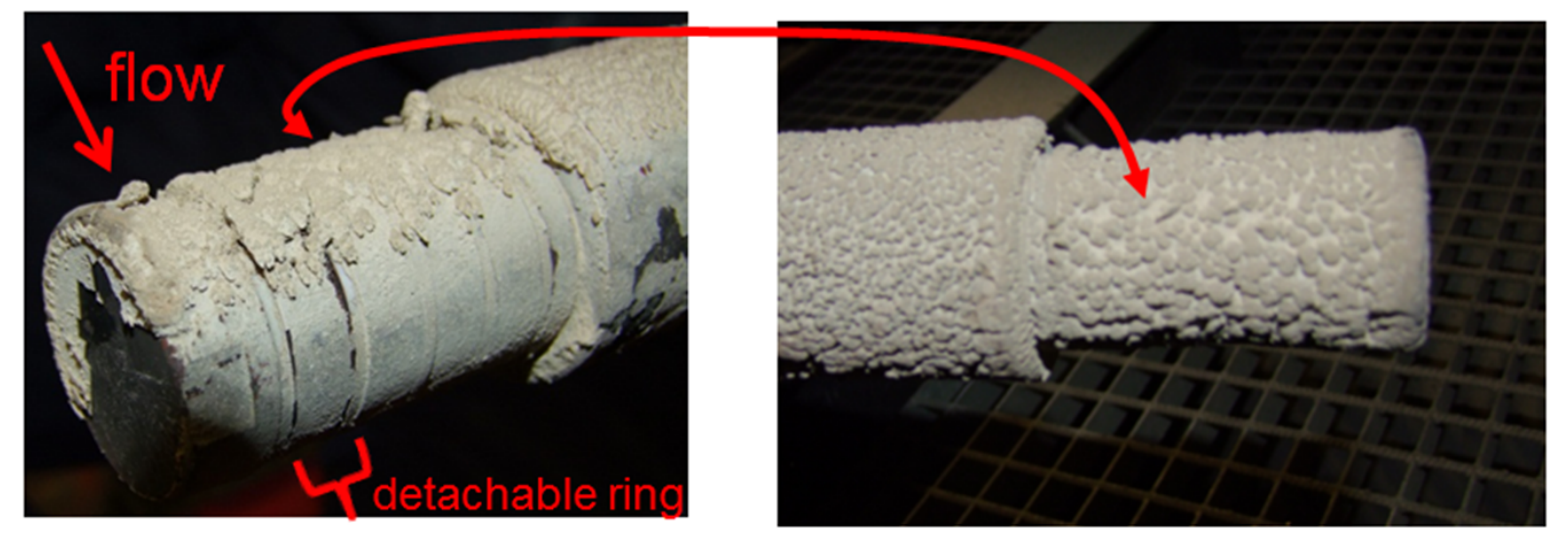

Figure 6.4 Deposits on air cooled probe after test 2; side view (left) and top view (right).

The samples were put in epoxy resin which hardens in 6 hours, and cross sections were grinded and polished (water free, using kerosene as cooling medium). Carbon was deposited on the sample surface to overcome charging during SEM investigations. Backscatter plots and secondary electron plots were produced and the composition was analysed on micro-scale level with EDS (Energy Dispersive x-ray Spectroscopy). Point analyses were made in combination with back scatter plots for the test 1 sample. This was also done for the test 2 and 3 samples and KEMPhase recordings were made in addition. KEMPhase is an in-house developed tool which enables the results of EDS analysis to be presented as false colour representations of the distribution of predefined phases.

\subsubsection{Thermodynamic equilibrium calculations}

Thermodynamic equilibrium calculations were conducted with FactSage (see [5] for a general description) which includes an extensive component and solution database. Thermodynamic calculations have their limitations, as was reviewed by Becidan et al. [6]: although the residence time of particles in the boiler is fairly long, the bed temperature is relatively low (max. $900^{\circ} \mathrm{C}$ ), and the combusting particles are quite large. Hence, the equilibrium state is not (completely) reached during combustion and kinetics play a significant role. Also the mode of occurrence of elements in the fuel, temperature gradients, concentration gradients and physical processes like adsorption are not taken into account. These drawbacks can be accounted for, as was also described by 
Becidan et al. For example, by selection of the database components that on basis of practical experience can be expected, kinetic constraints can be partly taken into account. The influence of mode of occurrence of elements in the fuel can be translated by adapting the calculation input based on availability of elements for reaction. Often, biomass is characterized with chemical fractionation (CF) and the elements in the fuel are regarded reactive (hence, input for the equilibrium calculations), to the extent that they are soluble in water or acetate [7]. This reactive fraction is interpreted as being water soluble salts and organically bound elements. The remainder, $\mathrm{HCl}$-soluble or non-soluble, is considered to consist of non-reactive minerals, and is not taken into account in the equilibrium calculations. However, the high fraction of $\mathrm{Ca}$ in bark that was only soluble in $\mathrm{HCl}$ was explained by [7] as Ca occurring as calcite or calcium oxalate. These minerals can react below $900{ }^{\circ} \mathrm{C}$ with gaseous sulphur compounds and should therefore be taken into account in equilibrium calculations for prediction of fouling. Moreover, in the approach taken by [7], the water and acetate soluble fraction is regarded as fly ash and the $\mathrm{HCl}-$ soluble and non-soluble fraction as bottom ash. Considering the CF results of wood by TortosaMasiá et al. [8], Si, Ti, Al, Mg and $\mathrm{P}$ would be $0 \%$ reactive, and, following the approach of [7], the fly ash would be depleted in these elements. This is, however, not true: a mass balance showed that in our tests, the percentage of the elements going to the fly ash is Al: $50 \%$, Ca: $60 \%$, Fe: 55\%, K: 45\%, Mg: 55\%, P: 65\%, Si: 35\% and Ti: 45\% (the remainder goes to the bottom ash). Therefore we have adapted the approach of [7] where we regard all elements, including those being part of the $\mathrm{HCl}$-soluble and non-soluble fraction, as (partly) reactive by assuming that the outer atom layers can interact with the gas phase. When assuming spherical particles with an outer reactive layer of $0.5 \mu \mathrm{m}$, this gives with the measured particle size distribution of the fly ash $(\mathrm{d} 50=17 \mu \mathrm{m})$ a reactive fraction of $19.4 \%$. This value, multiplied with the aforementioned percentages with which elements end up in the fly ash, is regarded as the availability of the outer layer. The maximum of this availability and of the availability according to CF results is used in our calculations, see Table 6.4. CF results for wood have been obtained from Tortosa-Masiá et al. [8], and for grass and paper sludge from Baxter [9]. Paper sludge ash consists of paper filler, consisting of the reactive minerals free lime, calcium carbonate and (meta-)kaolinite and some titanium dioxide. The paper filler particle size is normally distributed and diameters of calciumcontaining, (meta-)kaolinite and titanium oxide particles and are about $0.5-3.0 \mu \mathrm{m}, 0.7-1.5$ $\mu \mathrm{m}$, and $0.2-0.4 \mu \mathrm{m}$, respectively, see e.g. Gill [10]. Assuming again an outer reactive layer of $0.5 \mu \mathrm{m}$, availabilities are calculated as stated in Table 6.4. 
Table 6.4 Fuel blends composition. Concentrations on basis of mass (a.r.).

\begin{tabular}{|c|c|c|c|c|c|c|c|c|}
\hline & & wood & & grass & & $\begin{array}{l}\text { paper } \\
\text { sludge }\end{array}$ & & \\
\hline & $\begin{array}{l}\text { available } \\
\text { outer } 0.5 \\
\mu \mathrm{m} \text { layer }\end{array}$ & $\begin{array}{l}\text { availability } \\
\text { based on } \\
\text { CF }\end{array}$ & maximum & $\begin{array}{l}\text { availability } \\
\text { based on } \\
\text { CF }\end{array}$ & maximum & $\begin{array}{c}\text { available } \\
\text { outer } 0.5 \\
\mu \mathrm{m} \text { layer }\end{array}$ & $\begin{array}{l}\text { availability } \\
\text { based on } \\
\mathrm{CF}\end{array}$ & maximum \\
\hline Al & $10 \%$ & $0 \%$ & $10 \%$ & $1 \%$ & $10 \%$ & $99 \%$ & $0 \%$ & $99 \%$ \\
\hline $\mathrm{Ca}$ & $12 \%$ & $21 \%$ & $21 \%$ & $49 \%$ & $49 \%$ & $91 \%$ & $45 \%$ & $91 \%$ \\
\hline $\mathrm{Cl}$ & & $100 \%$ & $100 \%$ & $100 \%$ & $100 \%$ & & $76 \%$ & $76 \%$ \\
\hline $\mathrm{Fe}$ & $11 \%$ & $0 \%$ & $11 \%$ & $6 \%$ & $11 \%$ & & $0 \%$ & $0 \%$ \\
\hline K & $9 \%$ & $100 \%$ & $100 \%$ & $92 \%$ & $92 \%$ & & $84 \%$ & $84 \%$ \\
\hline $\mathrm{Mg}$ & $11 \%$ & $56 \%$ & $56 \%$ & $73 \%$ & $73 \%$ & & $23 \%$ & $23 \%$ \\
\hline $\mathrm{Na}$ & $9 \%$ & $100 \%$ & $100 \%$ & $33 \%$ & $33 \%$ & & $100 \%$ & $100 \%$ \\
\hline$P$ & $13 \%$ & $0 \%$ & $13 \%$ & $72 \%$ & $72 \%$ & & $11 \%$ & $11 \%$ \\
\hline S & & $84 \%$ & $84 \%$ & $54 \%$ & $54 \%$ & & $0 \%$ & $0 \%$ \\
\hline $\mathrm{Si}$ & $7 \%$ & $1 \%$ & $7 \%$ & $2 \%$ & $7 \%$ & $99 \%$ & $1 \%$ & $99 \%$ \\
\hline $\mathrm{Ti}$ & $9 \%$ & $0 \%$ & $9 \%$ & $0 \%$ & $9 \%$ & $100 \%$ & $0 \%$ & $100 \%$ \\
\hline
\end{tabular}

A pressure of $1 \mathrm{~atm}$., a temperature range of 300 to $900{ }^{\circ} \mathrm{C}$, and a typical air excess ratio $(\lambda)$ of 1.26 (corresponding to $4.3 \%$ oxygen in the dry flue gases) was considered in the equilibrium calculations. The air excess ratio is defined as the mass of air used for combustion divided by the mass of air needed for stoichiometric combustion.

\subsection{Results}

\subsubsection{Microscopy and chemical analysis}

\subsubsection{Test 1}

The top of the deposit (part A, see Figure 6.5) is quite homogeneous and solid in composition, and consists of $\mathrm{CaSO}_{4}$ and $\mathrm{K}_{2} \mathrm{SO}_{4}$ with typically $12-15 \% \mathrm{Ca}$, and $4-7 \% \mathrm{~K}$. Element concentrations are given in this section always as atom percentage. Figure 6.5 shows discrete particles of ca. $0.1 \mathrm{~mm}$ diameter at the upper side of part $\mathrm{B}$ which are quartz particles, coated with a mixture of $\mathrm{K}_{2} \mathrm{SO}_{4}$ and $\mathrm{Na}_{2} \mathrm{SO}_{4}$ with a $\mathrm{K}$ to $\mathrm{Na}$ ratio of 3:1. The particles are situated between homogeneous, solid areas of the mixture that also contains ca. $4 \% \mathrm{Ca}$. The bottom side of part $\mathrm{B}$ has a layered structure, consisting of $\mathrm{CaSO}_{4}$ and $\mathrm{K}_{2} \mathrm{SO}_{4}$ with typically $10-20 \% \mathrm{Ca}$, and $8-21 \% \mathrm{~K}$. The deposit that has built directly on top of the tube metal consists mainly of discrete particles of $\mathrm{CaO}, \mathrm{CaCO}_{3}, \mathrm{SiO}_{2}$, calcium-(aluminium, magnesium)silicates, $\mathrm{CaSO}_{4}, \mathrm{~K}_{2} \mathrm{SO}_{4}$ and $\mathrm{Ca}_{3}\left(\mathrm{PO}_{4}\right)_{2}$ and chlorides. 

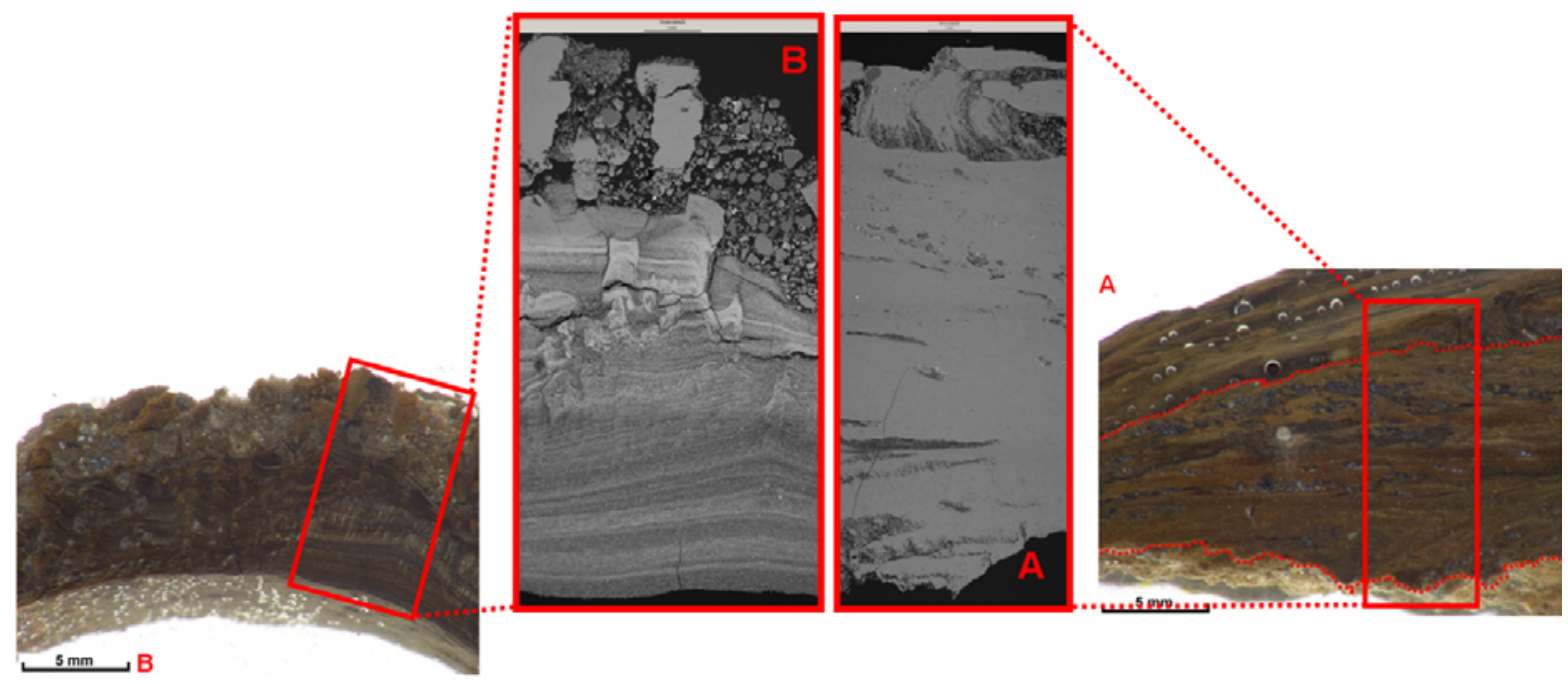

Figure 6.5 Cross section of superheater deposits test 1. Light microscopic image (left). SEM image (right).

\subsubsection{Test 2}

The bed temperature during the test when the deposits were sampled was $880-890{ }^{\circ} \mathrm{C}$. The resulting deposits are shown in Figure 6.6. The bulk composition as well as the average composition of the initial $500 \mu \mathrm{m}$ is shown in Table 6.5. The deposits are grain-like, and the 'grains' have a layered structure. The bulk of the deposit consists of a mixture of $\mathrm{CaSO}_{4}$ and $\mathrm{K}_{2} \mathrm{SO}_{4}$ with Ca-concentration higher than the $\mathrm{K}$-concentration. The Ca-concentration is typically between 4 and $12 \%$; $\mathrm{Na}$ is also present in the mixture and has a concentration of $0-3 \%$. Some $\mathrm{K}_{2} \mathrm{SO}_{4}, \mathrm{Na}_{2} \mathrm{SO}_{4}$ and $\mathrm{CaSO}_{4}$ are found on the metal-deposit interface but much less than as found in test 3 (see further in 6.3.1.3). The sulphate mixture has a porous structure which glues together and encapsulates other particles. Chlorides are locally present, either as discrete phases or condensed on the surface of larger particles. The bulk $\mathrm{Cl}$-concentration is $0.3 \%$, but is up to $16 \%$ locally, where $\mathrm{Cl}$ occurs mainly as $\mathrm{KCl}$. The average composition of the initial layer of $500 \mu \mathrm{m}$ differs from the bulk composition: it contains more $\mathrm{Na}$ and less $\mathrm{K}$, and $\mathrm{S}$, and more $\mathrm{Al}$ and $\mathrm{Si}$. Other present particles are quartz $\left(\mathrm{SiO}_{2}\right)$, calcium silicates, $\mathrm{CaO}, \mathrm{CaCO}_{3}$ and pure aluminium. Some Al particles are $100 \mu \mathrm{m} \times 500 \mu \mathrm{m}$ whereas the discrete Ca-containing particles are typically $<40 \mu \mathrm{m}$. The results obtained during the test where the bed temperature was $800-$ $820^{\circ} \mathrm{C}$ were similar to the results obtained at the higher bed temperature regarding structure and chemical composition. 

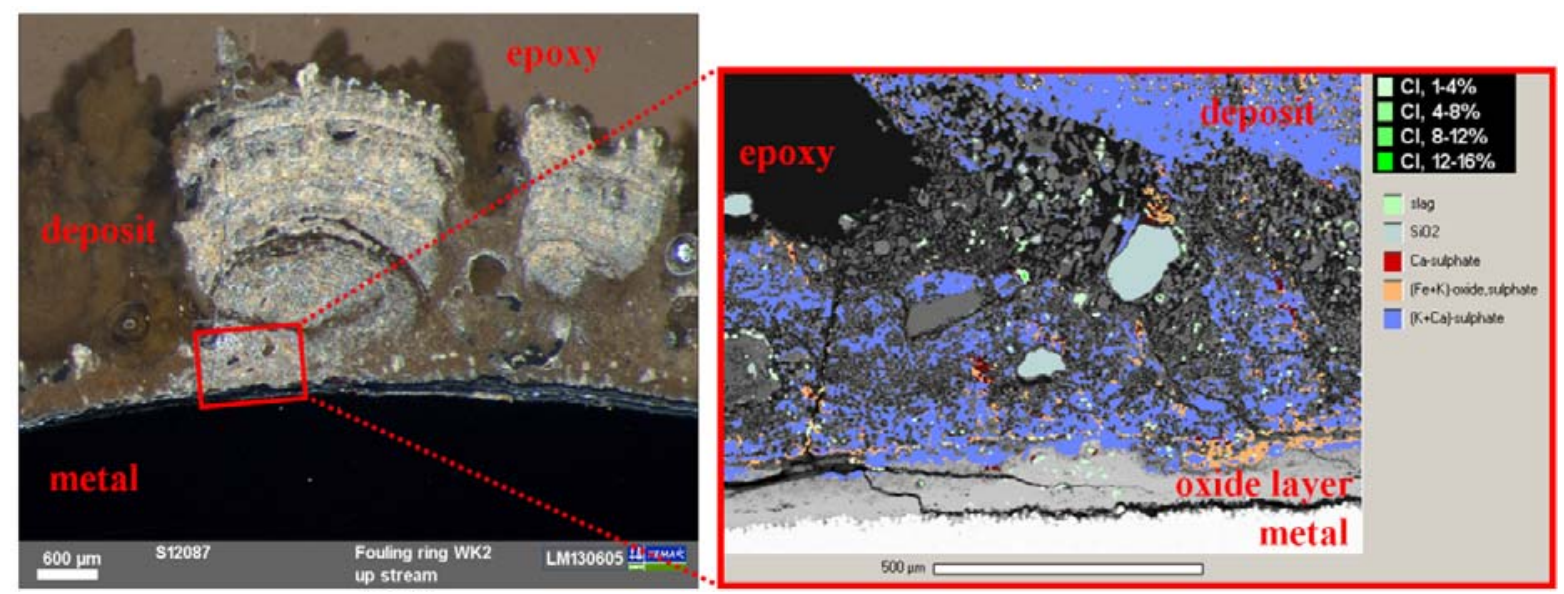

Figure 6.6 Cross section of probe upstream deposits test 2. Light microscopic image (left). SEM image (right).

Table 6.5 Deposit composition of tests 2 and 3 (average of initial $500 \mu \mathrm{m}$ and bulk). Concentrations in atom\%.

\begin{tabular}{lllll}
\hline & $\begin{array}{l}\text { test } \\
\text { (initial }\end{array}$ & & $\begin{array}{l}\text { test } \\
\text { (initial }\end{array}$ \\
& $500 \mu \mathrm{m})$ & test 2 bulk & $500 \mu \mathrm{m})$ & test 3 (bulk) \\
\hline $\mathrm{O}$ & $61.0 \%$ & $58.5 \%$ & $53.0 \%$ & $57.9 \%$ \\
$\mathrm{Na}$ & $3.4 \%$ & $0.6 \%$ & $2.5 \%$ & $1.9 \%$ \\
$\mathrm{Mg}$ & $0.8 \%$ & $1.0 \%$ & $1.4 \%$ & $1.0 \%$ \\
$\mathrm{Al}$ & $2.3 \%$ & $0.8 \%$ & $7.1 \%$ & $0.9 \%$ \\
$\mathrm{Si}$ & $3.6 \%$ & $1.3 \%$ & $3.8 \%$ & $2.5 \%$ \\
$\mathrm{P}$ & $0.4 \%$ & $0.3 \%$ & $0.6 \%$ & $0.6 \%$ \\
$\mathrm{~S}$ & $8.0 \%$ & $14.1 \%$ & $9.3 \%$ & $12.9 \%$ \\
$\mathrm{Cl}$ & $0.3 \%$ & $0.3 \%$ & $0.4 \%$ & $0.4 \%$ \\
$\mathrm{~K}$ & $5.6 \%$ & $8.9 \%$ & $7.1 \%$ & $8.6 \%$ \\
$\mathrm{Ca}$ & $12.6 \%$ & $12.7 \%$ & $8.7 \%$ & $11.0 \%$ \\
$\mathrm{Ti}$ & $0.1 \%$ & $0.0 \%$ & $1.0 \%$ & $0.2 \%$ \\
$\mathrm{Fe}$ & $1.7 \%$ & $1.4 \%$ & $4.7 \%$ & $2.1 \%$ \\
\hline
\end{tabular}

\subsubsection{Test 3}

Grain-like deposits are visible in Figure 6.7, while an upstream layer has formed on top of the grains that is wedge-shaped (half of the 'wedge' can be seen in Figure 6.7). The wedge is porous and consists mainly of $\mathrm{CaSO}_{4}$ and $\mathrm{K}_{2} \mathrm{SO}_{4}$; concentrations are: $\mathrm{Ca} 10-12 \%, \mathrm{~K} 6-8 \%$ and $\mathrm{Na}$ 
$1.5-3 \%$. The grains also consist of $\mathrm{CaSO}_{4}$ and $\mathrm{K}_{2} \mathrm{SO}_{4}$ with the same Ca-concentration as in the wedge, but a somewhat higher K-concentration: $7-11 \%$. The left side of the examined cross section of the part of the deposit as shown in Figure 6.7, is enriched in $\mathrm{Na}$ with a concentration gradient of $\mathrm{Ca}, \mathrm{K}$ and $\mathrm{Na}$ from bottom (ring side) to top evolving from 11 to $5 \%, 3$ to $10 \%$ and $<0.5$ to $3 \%$, respectively. The bulk composition as well as the average composition of the initial $500 \mu \mathrm{m}$ is shown in Table 6.5. Chlorides are present, either as discrete particles or on large particle surfaces. The bulk Cl-concentration is $0.4 \%$, but is up to $4 \%$ locally. Chlorides occur mainly as $\mathrm{KCl}$. The average composition of the initial layer of $500 \mu \mathrm{m}$ differs from the bulk composition: as in the test 2 deposit, it contains more $\mathrm{Na}$ and less $\mathrm{K}$, and $\mathrm{S}$, and more $\mathrm{Al}$ and $\mathrm{Si}$, but the differences are lower than in test 2, except for Al. A $\sim 75 \mu \mathrm{m}$ thick $\mathrm{K}_{2} \mathrm{SO}_{4}-\mathrm{Na}_{2} \mathrm{SO}_{4}-\mathrm{CaSO}_{4}$ layer $(16 \% \mathrm{~K}, 4 \% \mathrm{Na}$ and $2 \% \mathrm{Ca})$ is present on the metal surface. Discrete particles in the deposit are quartz, calcium silicates, $\mathrm{CaO}, \mathrm{CaCO}_{3}$ and pure aluminium of a size similar to the discrete particles found in the deposit in test 2.

Also some deposit was found at the downstream side of the probe. While a $<50 \mu \mathrm{m}$ layer of $\mathrm{CaSO}_{4}$ and $\mathrm{K}_{2} \mathrm{SO}_{4}$ is present on the metal (both $\mathrm{Ca}$ and $\mathrm{K}$ have a concentration of ca. $10 \%$ ), the main deposit consists of almost pure Al- particles $(100 \times 500 \mu \mathrm{m})$, 'stacked' with layers of a mixture of $\mathrm{CaSO}_{4}$ and $\mathrm{K}_{2} \mathrm{SO}_{4}$ (concentrations of $\mathrm{K}$ and $\mathrm{Ca}$ are 12.5 and $8.5 \%$, respectively).
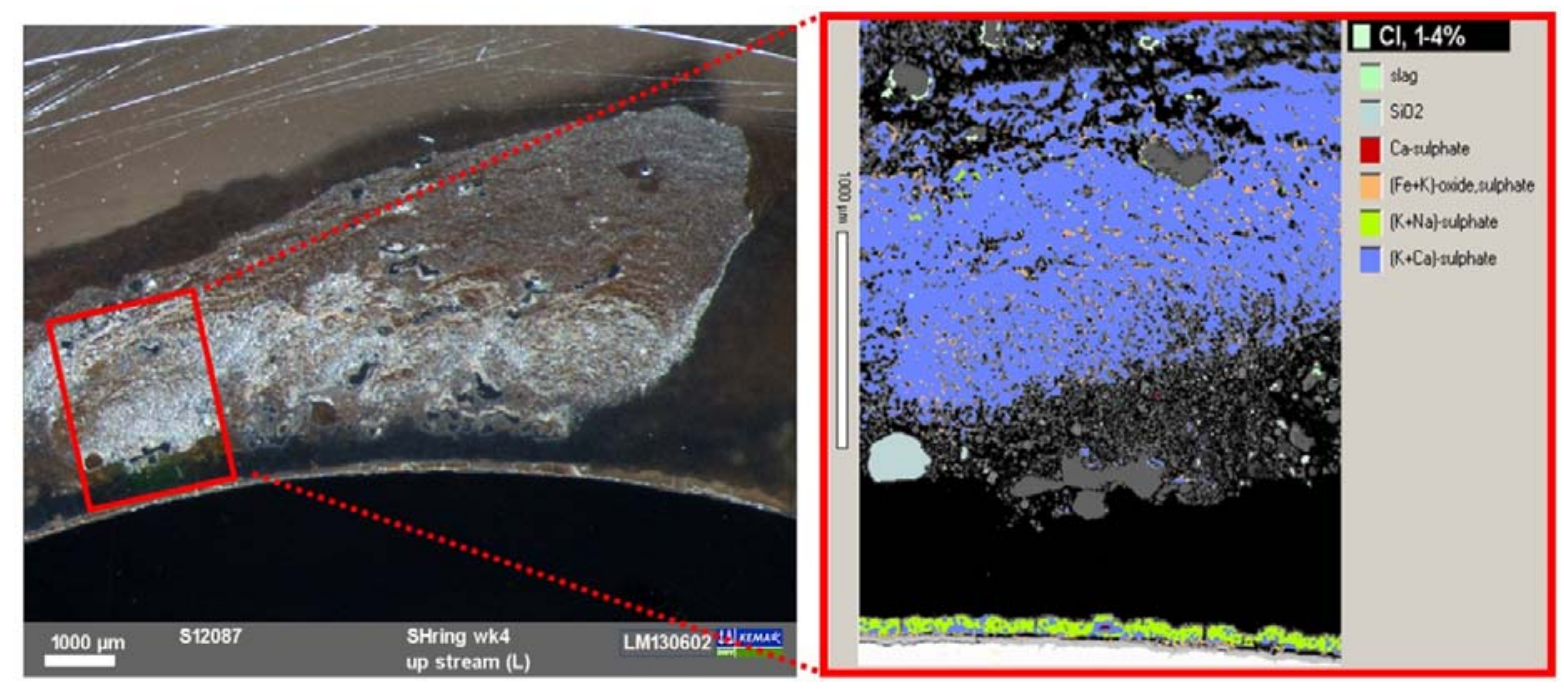

Figure 6.7 Cross section of probe upstream deposits test 3. Light microscopic image (left). SEM image (right).

\subsubsection{Deposition rates on probe}

The maximum thickness of the deposit on the probe, is at the upstream side which is approximately $3.2 \mathrm{~mm}$ after test 2, and, $4.7 \mathrm{~mm}$ after test 3 . Most deposit is situated at the 
upstream side of the probe, at the surface perpendicular to the flue gas flow - the amount decreases with the angle towards the downstream side of the probe. However, some deposit was found at that downstream side at the surface perpendicular to the flue gas flow after test 3 , with a maximum thickness of ca. $0.9 \mathrm{~mm}$. The deposition rates of tests 2 and 3 were $0.29 \mathrm{~g} \cdot \mathrm{m}^{-2} \cdot \mathrm{s}^{-1}$ and $0.33 \mathrm{~g} \cdot \mathrm{m}^{-2} \cdot \mathrm{s}^{-1}$ on average, respectively.

\subsubsection{Thermodynamic calculation results}

\subsubsection{Sulphur}

The results of the thermodynamic calculation for sulphur compounds are shown in Figures 6.8 and 6.9. These figures show that a small fraction of sulphur occurs as gaseous stable compounds $\left(\mathrm{K}_{2} \mathrm{SO}_{4}\right.$ and $\left.\mathrm{SO}_{2}\right)$ at the bed temperature. Mainly, $\mathrm{S}$ is a component in the molten $\mathrm{K}$ $\mathrm{Na}-\mathrm{SO}_{4}-\mathrm{Cl}$ salt. Solid $\mathrm{CaSO}_{4}$ forms the majority of the sulphur-bearing compounds in test 1 , is also present in test 3 but not present at tests 0 and 2. Potassium sulphate start to solidify at $>900$ ${ }^{\circ} \mathrm{C}$ (test 0 ), $650{ }^{\circ} \mathrm{C}$ (test 1), $560{ }^{\circ} \mathrm{C}$ (test 3), $525{ }^{\circ} \mathrm{C}$ (test 2) while in all cases, all melt has solidified at $460^{\circ} \mathrm{C}$ (which is about $40 \mathrm{~K}$ above the superheater metal temperature).

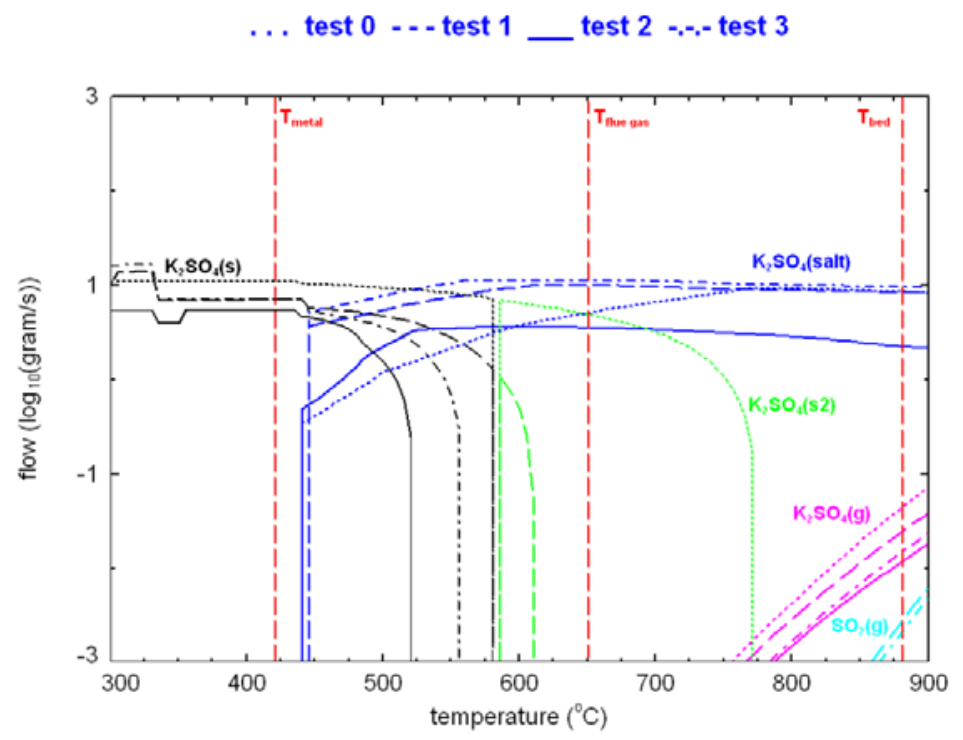

Figure 6.8 Sulphur components $\left(\mathrm{SO}_{2}\right.$ and K-compounds), thermodynamic equilibrium. " $\mathrm{K}_{2} \mathrm{SO}_{4}$ (salt)" represents the $\mathrm{K}_{2} \mathrm{SO}_{4}$-component in the molten $\mathrm{K}-\mathrm{Na}-\mathrm{SO}_{4}-\mathrm{Cl}$ salt. 


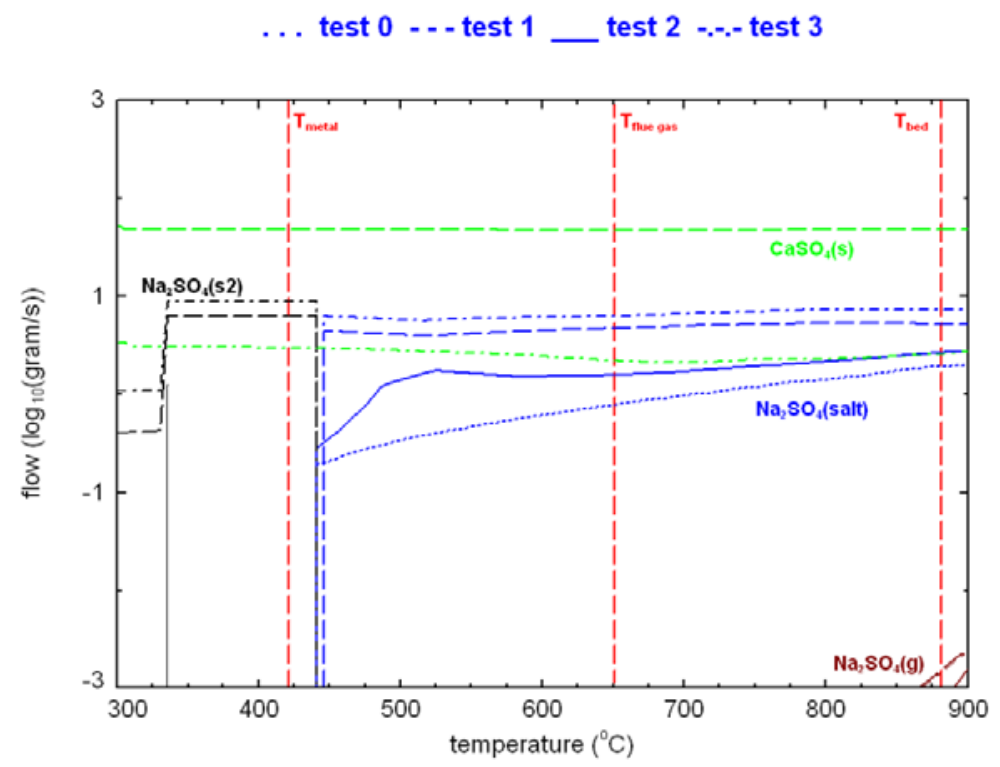

Figure 6.9 Sulphur components ( $\mathrm{Ca}$ - and Na-compounds), thermodynamic equilibrium. " $\mathrm{Na}_{2} \mathrm{SO}_{4}$ (salt)" represents the $\mathrm{Na}_{2} \mathrm{SO}_{4}$-component in the molten $\mathrm{K}-\mathrm{Na}-\mathrm{SO}_{4}-\mathrm{Cl}$ salt.

\subsubsection{Chlorine}

The results of the thermodynamic calculation for $\mathrm{Cl}$-compounds are shown in Figures 6.10 and 6.11. These figures show that gaseous $\mathrm{Cl}$-components are present in the bed, mainly as $\mathrm{KCl}$, but also some $\mathrm{NaCl}$ and $\mathrm{HCl}$. A small part of the $\mathrm{Cl}$ is present in the molten $\mathrm{K}-\mathrm{Na}-\mathrm{Cl}-\mathrm{SO}_{4}$ salt at the bed temperature, but this increases to a maximum at ca. $550{ }^{\circ} \mathrm{C}$ when $\mathrm{KCl}$ starts to solidify. Only $\mathrm{KCl}(\mathrm{s})$ is present as condensed phase, at the metal temperature of $420^{\circ} \mathrm{C}$. 


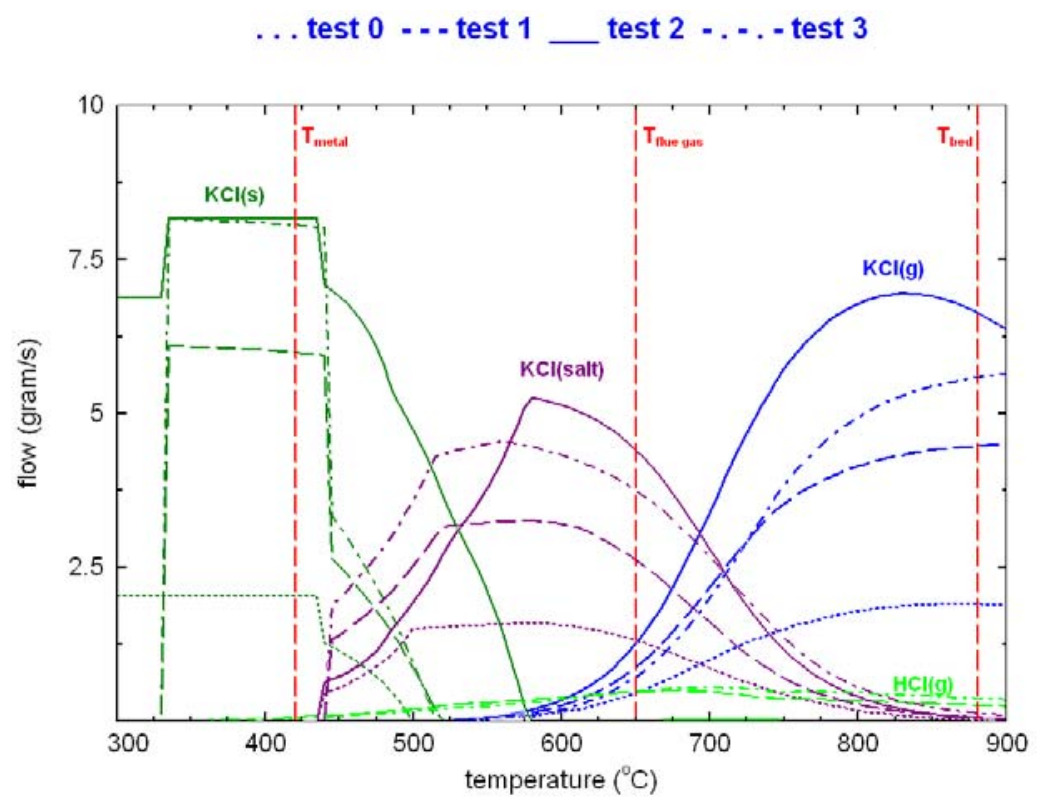

Figure 6.10 Chlorine components ( $\mathrm{HCl}$ and $\mathrm{K}$-compounds), thermodynamic equilibrium. "KCl(salt)" represents the $\mathrm{KCl}$-component in the molten $\mathrm{K}-\mathrm{Na}-\mathrm{SO}_{4}-\mathrm{Cl}$ salt.

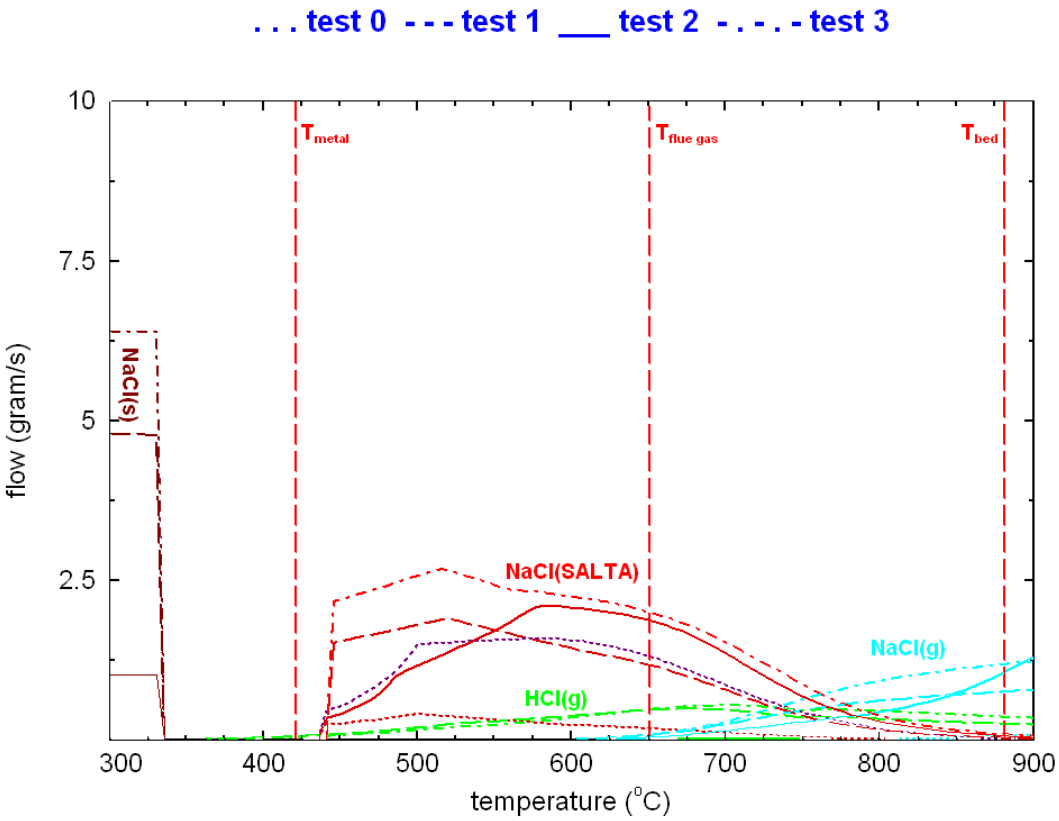

Figure 6.11 Chlorine components ( $\mathrm{HCl}$ and $\mathrm{Na}$-compounds), thermodynamic equilibrium. " $\mathrm{NaCl}$ (salt)" represents the $\mathrm{NaCl}$-component in the molten $\mathrm{K}-\mathrm{Na}-\mathrm{SO}_{4}-\mathrm{Cl}$ salt. 


\subsubsection{Calcium}

Calcium is present as solid compound in the bed as free lime $(\mathrm{CaO}), \mathrm{CaSO}_{4}, \mathrm{CaCO}_{3}$, and $\mathrm{Ca}_{2} \mathrm{SiO}_{4}$ and a small amount of $\mathrm{Ca}_{5} \mathrm{HO}_{13} \mathrm{P}_{3}$. The relative distribution varies per test: the majority is $\mathrm{CaO}$ and $\mathrm{CaCO}_{3}$ in tests 0,2 and 3 , and $\mathrm{CaSO}_{4}$ and $\mathrm{CaCO}_{3}$ in test $1 . \mathrm{CaO}$ is substituted by $\mathrm{CaCO}_{3}$ below $750{ }^{\circ} \mathrm{C}$. In all cases, stable compounds at flue gas temperature at $\mathrm{SH} 1\left(650{ }^{\circ} \mathrm{C}\right)$, are, in descending relative amounts, $\mathrm{CaCO}_{3}, \mathrm{Ca}_{2} \mathrm{SiO}_{4}$ and $\mathrm{Ca}_{3} \mathrm{HO}_{13} \mathrm{P}_{3} ; \mathrm{CaSO}_{4}$ is also stable in tests 1 and 3 (less than $\mathrm{CaCO}_{3}$ ). $\mathrm{Ca}_{2} \mathrm{SiO}_{4}$ is substituted by $\mathrm{CaSiO}_{3}$ and partly $\mathrm{Ca}_{3} \mathrm{Fe}_{2} \mathrm{Si}_{3} \mathrm{O}_{12}$ below $550^{\circ} \mathrm{C}$. At the metal temperature of $\mathrm{SH} 1\left(420{ }^{\circ} \mathrm{C}\right)$, the main thermodynamically stable compounds are $\mathrm{CaCO}_{3}, \mathrm{CaSiO}_{3}$ and in tests 1 and 3 also $\mathrm{CaSO}_{4}$.

\subsubsection{Other elements}

Stabilities of $\mathrm{K}$ and $\mathrm{Na}$ are given in Figures 6.8 and 6.10, and are discussed in sections 6.3.3.1 and 6.3.3.2. Aluminium is stable as $\mathrm{MgAl}_{2} \mathrm{O}_{4}(\mathrm{~s})$ in all tests at the temperature range of $900-420$ ${ }^{\circ} \mathrm{C}$, and also $\mathrm{Al}_{2} \mathrm{O}_{3}$ (s) in test 2. The main stable $\mathrm{Mg}$-component is $\mathrm{MgAl}_{2} \mathrm{O}_{4}(\mathrm{~s})$ in tests 1 and 2 , while this is $\mathrm{MgO}$ in tests 0 and 3. Silicon is stable as $\mathrm{Ca}_{2} \mathrm{SiO}_{4}(\mathrm{~s})$ at $900{ }^{\circ} \mathrm{C}$ and $650{ }^{\circ} \mathrm{C}$ and as $\mathrm{CaSiO}_{3}(\mathrm{~s})$ and $\mathrm{Ca}_{2} \mathrm{Fe}_{2} \mathrm{Si}_{3} \mathrm{O}_{2}$ (s) at $420{ }^{\circ} \mathrm{C}$ in all tests. Titanium is stable as $\mathrm{TiO}_{2}(\mathrm{~s})$ over the temperature range $900-300^{\circ} \mathrm{C}$ in all tests.

\subsection{Discussion}

\subsubsection{Ash transport and deposit build-up and development}

Inorganic elements, especially those present in the fuel as water-soluble salts or as organically bound elements, can evaporate during combustion. The degree of evaporation depends on the $\mathrm{Cl}$ content in the fuel [11]. According to the equilibrium results, gaseous alkalis occur mainly as $\mathrm{KCl}(\mathrm{g})$ and $\mathrm{NaCl}(\mathrm{g})$ in tests 1,2 and 3 , and $\mathrm{KOH}(\mathrm{g})$ and $\mathrm{NaOH}(\mathrm{g})$ in test 0 (concentrations of $\mathrm{K}_{2} \mathrm{SO}_{4}(\mathrm{~g})$ and $\mathrm{Na}_{2} \mathrm{SO}_{4}(\mathrm{~g})$ are a factor of 100 and 500 lower, respectively). The molar ratio between gaseous $\mathrm{K}$ and $\mathrm{Na}$ at $900{ }^{\circ} \mathrm{C}$ in equilibrium is about $6: 1$ or more in all tests. Vaporized elements condense in the bed or upon cooling, either homogeneously or heterogeneously. Heterogeneous condensation is favoured by a lower cooling rate and by the presence of available surface onto which the vapour can condense, i.e. by a lower size of the present particles. Vapours condensing homogeneously or heterogeneously on small particles form the submicron part of the fly ash. Our equilibrium results show that $\mathrm{K}_{2} \mathrm{SO}_{4}$ condenses already at the bed temperature (ca. $900{ }^{\circ} \mathrm{C}$ ), while $\mathrm{KCl}$ condenses at lower temperature. Jiménez and Ballester [12] found experimentally that with combustion of orujillo, particles collected at $900{ }^{\circ} \mathrm{C}$ contained only potassium and sulphur, while $\mathrm{Cl}$ was also present in samples collected at $560^{\circ} \mathrm{C}$ and below. With sufficient $\mathrm{SO}_{2}$, the formation of fine $\mathrm{KCl}$ particles could be completely suppressed. Jiménez and Ballester [13] showed that the relative ratio of $\mathrm{K}_{2} \mathrm{SO}_{4}$ in the fine particles is dependent on the 
initial $\mathrm{SO}_{2}$ and $\mathrm{O}_{2}$ concentration in the flue gases and that the conversion of $\mathrm{SO}_{2}$ to $\mathrm{SO}_{3}$ is the rate limiting step in $\mathrm{K}_{2} \mathrm{SO}_{4}$ formation, as was suggested earlier by Christensen et al. [14]. Equilibrium calculations therefore cannot accurately predict the $\mathrm{K}_{2} \mathrm{SO}_{4}: \mathrm{KCl}$ ratio of the condensed phase at temperatures well below $900{ }^{\circ} \mathrm{C}$. Small alkali particles can, when entering (or homogeneously condensing in) the boundary layer around the tube or deposit, be transported to the tube or deposit surface due to thermophoretic forces which at least partly explains that $\mathrm{K}_{2} \mathrm{SO}_{4}$ and $\mathrm{Na}_{2} \mathrm{SO}_{4}$ are bulk constituents in the deposit. The relative distribution of $\mathrm{K}$ and $\mathrm{Na}$ in the deposits can be explained by its relative distribution in the gas at $900{ }^{\circ} \mathrm{C}$ in equilibrium. As the thermophoretic force is relative to the temperature gradient, thermophoresis will become a less important phenomenon as the deposit grows and the deposit surface temperature increases. Eddy diffusion (i.e. mixing in a turbulent flow) and Brownian diffusion then become the principal deposition mechanism for particles of $<0.1 \mu \mathrm{m}$ [15]. Whether mainly fine $\mathrm{K}_{2} \mathrm{SO}_{4}$ particles, or also, or only, $\mathrm{KCl}$ particles have deposited, cannot be concluded from the fact that $\mathrm{K}_{2} \mathrm{SO}_{4}$ forms the bulk of the deposit. $\mathrm{KCl}$ can have also reacted when already deposited with gaseous $\mathrm{SO}_{\mathrm{x}}$ (sulphation). Short-term (1-3 hours) probe tests of Hansen [16] in a CFB-boiler firing coal and straw (50\% on basis of thermal heat input), showed deposits consisting largely of $\mathrm{KCl}$ (and probably some $\mathrm{K}_{2} \mathrm{SO}_{4}$ ). Matured deposits resulting from longer testing (in the order of 1 week), were $\mathrm{K}_{2} \mathrm{SO}_{4}$-dominated. Hansen [16] indicated that whether $\mathrm{KCl}$ or $\mathrm{K}_{2} \mathrm{SO}_{4}$ deposition took place, and/or subsequent sulphation, is dependent on the deposit surface temperature, the gas temperature and the gas composition. Gaseous alkalis in the boundary layer around the tube or deposit can also directly condense heterogeneously on the tube or deposit, which also may account for part of the $\mathrm{K}$ and $\mathrm{Na}$ in the deposit. Furthermore, as a consequence of the temperature gradient within a deposit, alkali chlorides in the outer, hotter, part of the deposit can be transported into the colder parts or to the tube surface by evaporation and subsequent condensation as was found on basis of laboratory experiments by Lindberg et al. [17].

Inorganic elements present as mineral inclusions in the fuel or excluded minerals form the coarse part of the fly ash. Larger particles, unable to follow the streamlines due to its inertia, impact on the upstream side of superheater tubes. This causes highest depositions rates at the stagnation point, hence the formation of a wedge-shaped deposit. In our tests, the coarse particles deposited by inertial impaction are mainly $\mathrm{CaO}, \mathrm{CaCO}_{3}, \mathrm{SiO}_{2}$ and calcium silicate particles, and in tests 2 and 3 also pure Al particles. Their composition can be explained by the thermodynamic equilibrium; larger particles, like quartz, are mainly inert during combustion and are not regarded in the equilibrium. These coarse particles are not molten at the flue gas temperature of $650{ }^{\circ} \mathrm{C}$ and can stick especially if the deposit surface is molten. This can have been the case when the deposit has matured and the outer surface temperature of the deposit has reached the temperature at which a molten salt mixture of $\mathrm{K}-\mathrm{Na}-\mathrm{SO}_{4}-\mathrm{Cl}$ is thermodynamically stable (in our case above $460{ }^{\circ} \mathrm{C}$, which is $40 \mathrm{~K}$ above the probe metal temperature). Deposits, down-stream of the tubes, are typically formed by eddy impaction: the flow detaches, and particles captured in eddies deposit at the down-stream side of the tube. 
A large part of the deposit consists of $\mathrm{CaSO}_{4}$ which acts as binder between particles. As can be seen in Figure 6.12, the solid (non-porous) deposit is formed by particles (grains) that have sintered in the deposit. The grain boundaries are visible and a slag particle (inert at temperatures below $650{ }^{\circ} \mathrm{C}$ ) has been encapsulated. The degree of sintering in tests 2 and 3 has been modest as the deposits were powdery and easy to remove, while the deposit from test 1 that matured over some weeks was hard and solid. Point analyses in different grains show a composition of $\mathrm{CaSO}_{4}$ and $\mathrm{K}_{2} \mathrm{SO}_{4}$ in a ratio of $3: 1$ and $\mathrm{CaSO}_{4}, \mathrm{~K}_{2} \mathrm{SO}_{4}$ and $\mathrm{Na}_{2} \mathrm{SO}_{4}$ in a ratio of 1:7:1. Sintering can have occurred by the occurrence of the molten salt mixture of $\mathrm{K}-\mathrm{Na}-\mathrm{SO}_{4}-\mathrm{Cl}$, filling pores. The melt can only exist when the Ca-content is low, or when the present $\mathrm{Ca}$ is chemically inert (as in calcium silicates or slag). When the flowing melt mixes with locally present $\mathrm{Ca}$, the melting point considerably increases and $\mathrm{CaSO}_{4}, \mathrm{~K}_{2} \mathrm{SO}_{4}$ and $\mathrm{Na}_{2} \mathrm{SO}_{4}$ will not form a melt in the deposit as the lowest melting temperature of this system is well above $800{ }^{\circ} \mathrm{C}$ [18]. Jensen et al. [19] showed with laboratory tests that sintering can take place at temperatures of $370-470{ }^{\circ} \mathrm{C}$ in ash high in $\mathrm{K}, \mathrm{Na}, \mathrm{S}$, and $\mathrm{Cl}$, but for wood combustion, where the Ca-content is generally higher, sintering starts generally at $780{ }^{\circ} \mathrm{C}$. Ca that has deposited as e.g. $\mathrm{CaO}$, can react with gaseous sulphur (Ca present as silicates will not react [12]), and occupy much more space than in its original mode of occurrence. Sulphation of $\mathrm{CaO}$ was detected by Skrifvars et al. [20] at a temperature as low as $600^{\circ} \mathrm{C}$. The difference in the degree of sintering between the probe deposits of tests 2 and 3 and the matured deposit of test 1 is likely due to a higher temperature in the matured deposit, as the thicker deposit will at a certain point attain the flue gas temperature. The higher temperature promotes sulphation of $\mathrm{Ca}$, and melt formation.

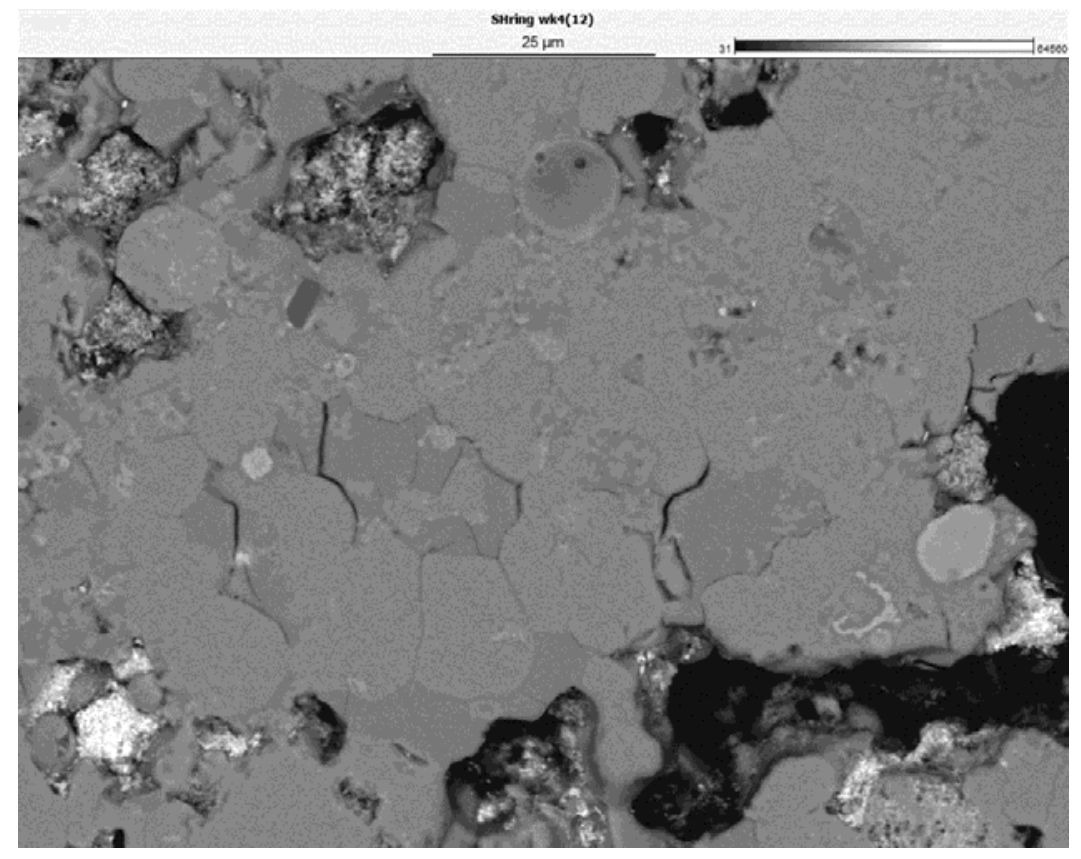

Figure 6.12 Sintered particles in the test 3 deposit, backscatter image. 
Sulphation of the deposits will depend on the gaseous S-content. Ca is present in wood, at least partly, as calcium oxalate. Calcium oxalate decomposes at $200{ }^{\circ} \mathrm{C}$, and in a combustion atmosphere these crystals will likely form very small and porous $\mathrm{CaO}$ particles as can be seen in the initial deposit from test 1 , see Figure 6.13. This creates a high reactive surface area where $\mathrm{CaSO}_{4}$ can be formed. This will take place in the bed or in the flue gas flow, rather than in the deposits. Also, the high surface area can promote heterogeneous condensation and drain the gas phase from gaseous alkalis. This overcomes condensation on and in the deposits. Evidently, the $\mathrm{CaO}$ loading has not been sufficient to suppress sulphation of the investigated deposits.

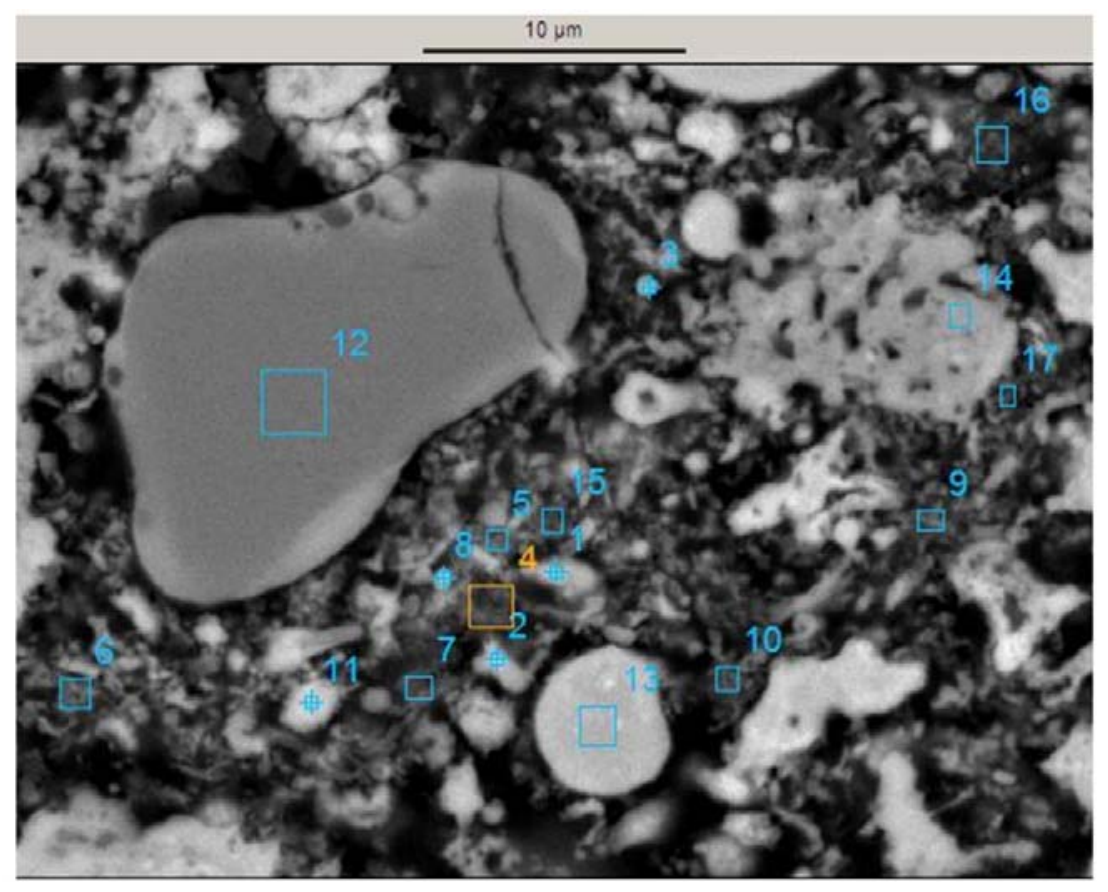

Figure 6.13 Particles in initial deposit (test 1), backscatter image. Analyses 1, 4-10, 15-17 in the deposit indicate a high calcium concentration (rest is oxygen and carbon that mainly results from the epoxy resin).

\subsubsection{Fouling prediction}

It was assumed by [7] that the melt percentage of total ash as predicted with equilibrium would be a good indicator for ash deposition risks, with a threshold value of $15 \%$, above which deposition would become problematic. The reasoning is that ash particles would have to contain a certain amount of liquid melt to deposit. The assumption of $15 \%$ was based on experience in black liquor recovery boilers. It could also be reasoned, however, that if the deposit surface is sticky, impacting particles can stick. This would not be related to the percentage of melt in the 
total ash, but to the extent at which a melt is present at the deposit temperature (i.e. temperature range between metal surface and local flue gas temperature). Both views were followed and results are plotted for all tests in Figures 6.14 and 6.15.

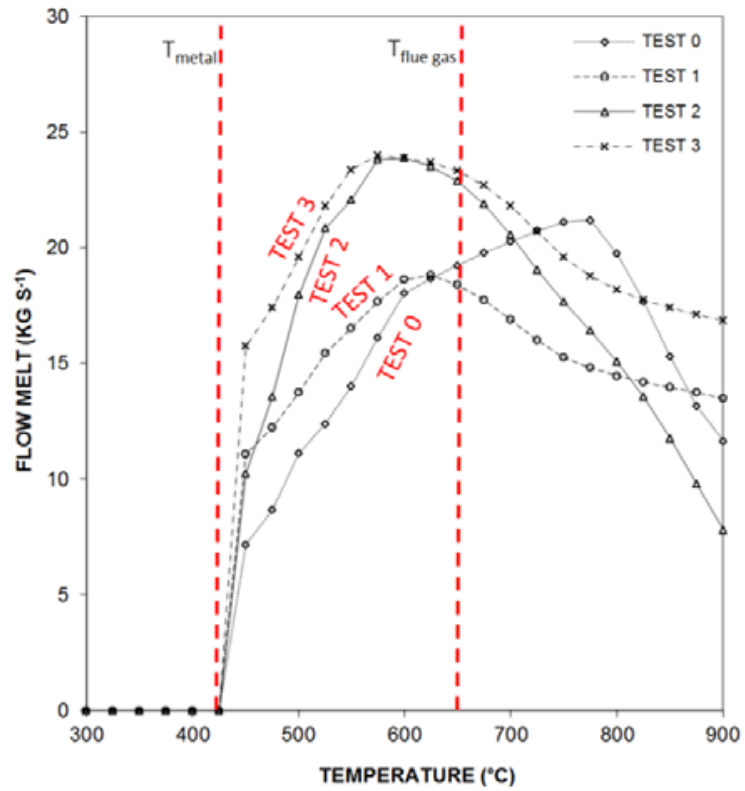

Figure 6.14 Equilibrium amount of molten salt.

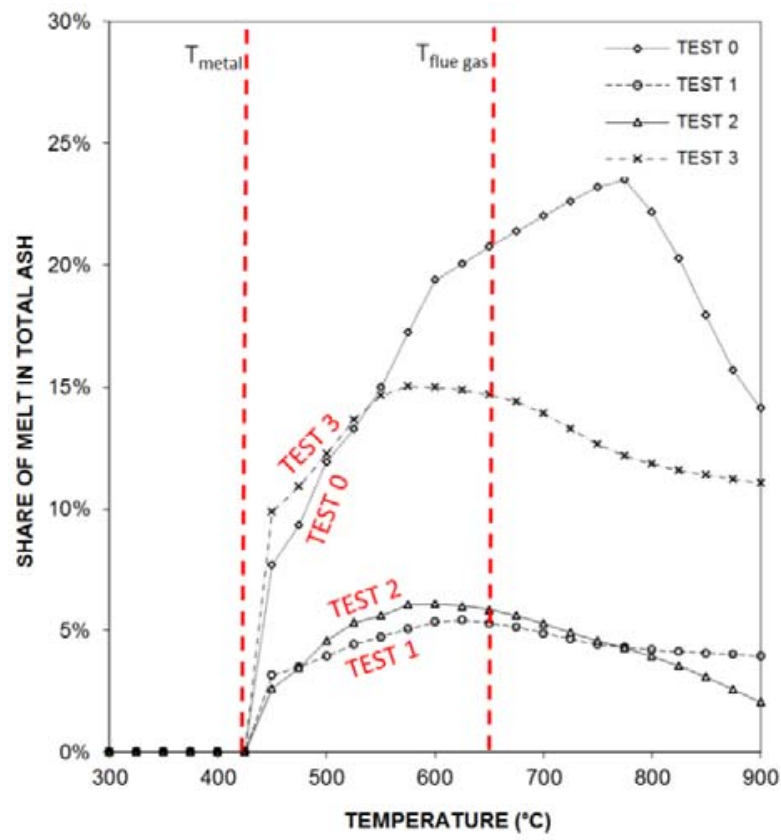

Figure 6.15 Equilibrium amount of molten salt as percentage of total ash. 
Comparisons in deposition behaviour from experience and probe testing, can be made between test 0 (the normal type of operation for 10 years) and test 1 : no major problems occurred at $\mathrm{SH} 1$, when firing wood pellets during test 0 , major problems occurred only after few weeks of testing, during test 1 . Furthermore, the deposition rates on the probes, during test 2 and 3 , were slightly higher in test 3 . This behaviour is reflected by the flow of molten salt between approximately 600 and $420^{\circ} \mathrm{C}$. Conversely, the share of molten ashes indicates problematic behaviour at test 0 and not at test 1 , and indicates a large difference in behaviour between tests 2 and 3 , which is both contradictory to our observations. The data presented above indicates that comparing equilibrium results on basis of the molten salt flow, is more in line with practice, and therefore shows that the fuel blends will be problematic regarding fouling of $\mathrm{SH} 1$ in the ranking test $3>$ test $2>$ test $1>$ test 0 . Our approach of using molten salt flow as a fouling predictor has been followed by others [21] who found modelling and experimental results were in good agreement. Also, they followed the approach of molten salt as percentage of the total condensed phase for which they also found - contrary to our findings - that modelling and experimental results were in good agreement. In the work of Moadian et al. [21], however, the gas phase is separated at $1,000{ }^{\circ} \mathrm{C}$ and the remainder, the "condensed phase", is not considered in simulation of the cooling of the gasses below $1,000{ }^{\circ} \mathrm{C}$. In our work, the gas phase is not separated. The amount of condensed phase in the approach of Moadian et al. will therefore be a constant value and therefore the variation of the amount of molten salt with temperature and the variation of molten salt as percentage of condensed phase with temperature are the same. Their results therefore confirm our findings on the amount of molten salt as predictor for fouling but don't contradict our findings on percentage of molten salt as percentage of total ash as fouling predictor because the amount of (condensed) ash is determined differently.

\subsection{Conclusions}

The bulk of the deposits in tests 1,2 , and 3 consist of a mixture of $\mathrm{CaSO}_{4}$, and $\mathrm{K}_{2} \mathrm{SO}_{4}$, and in tests 2 and 3 also of a minor concentration of $\mathrm{Na}_{2} \mathrm{SO}_{4}$. Discrete particles in the deposit are quartz, calcium silicates, $\mathrm{CaO}, \mathrm{CaCO}_{3}$ and pure aluminium of a size similar to the discrete particles found in the deposit in tests 2 and 3 . The occurrence of alkalis can be explained gaseous alkalis (present as chlorides, or in test 0 as hydroxide) that condenses as small particles in the flue gas or in the boundary layer above tube or deposit surface, that are transported to the tube or deposit surface by thermophoresis, and later, by eddy diffusion and Brownian diffusion. Also, the alkalis can condense homogeneously on or in the deposit. Whether $\mathrm{KCl}$ has deposited that later sulphatized, or that $\mathrm{K}_{2} \mathrm{SO}_{4}$ has deposited, or a combination of the two, cannot be established. The coarse particles, depositing by inertial impaction, were in some cases coated with alkalis. The deposits were sintered, to a modest extent in tests 2 and 3 and to a large extent in test 1 . This can be explained by sulphation of the present $\mathrm{Ca}$ and by liquid flow of molten $\mathrm{K}-$ $\mathrm{Na}-\mathrm{S}-\mathrm{Cl}$ salt. However, if the salt melt is mixed with $\mathrm{Ca}$, the melting point will increase, so this effect is assumed to occur where the Ca-content is low or when $\mathrm{Ca}$ is chemically inert (e.g. as 
calcium silicate or slag). Sintering increases with temperature and explains the higher degree of the matured deposit from test 1 . $\mathrm{CaO}$, resulting from decomposition of calcium oxalate (present in wood), could evidently not overcome sulphation.

The air-cooled probe tests showed that the deposition rate for the fuel blend used during test 3 was slightly higher than in test 2 . Based on equilibrium calculations, it is expected that deposition rates are rated regarding the fuel blends: test $0<$ test $1<$ test $2<$ test 3 . The amount of molten salt as predicted by equilibrium at deposit temperature (temperature range between metal surface temperature and local flue gas temperature), seems to be a better predictor for deposition propensity, compared to that amount of molten salt as a percentage of the total ash.

\section{References}

[1] Converting biomass to energy - a guide for developers and investors. International Finance Corperation, 2017.

[2] Miles Sr TR, Miles Jr TR, Baxter LL, Bryers RW, Jenkins BM, Oden LL. Boiler deposits from firing biomass fuel. Biomass Bioenerg, 1996, 10, 125-38.

[3] Peltola K, Hiltunen M, Blomqvist J-P, Skrifvars B-J, Kurkela J, Latva-Somppri J, et al. Fouling of the cooling surfaces in biofuels-fired fluidized bed boilers. In: Reuther RB, editor. Proceedings of the 15th International Conference on Fluidized Bed Combustion; May 16-19, 1999; Savannah, Georgia, USA. Savannah: ASME; 1999.

[4] Skrifvars B-J, Hupa M. (Åbo Akademi University, Åbo/Turku, Finland). Ash Chemistry and behavior in advanced co-combustion. In: Spliethoff $\mathrm{H}$, Hein KRG, editors. Final report of the EU/JOULE 3 project Operational problems, trace element emissions and by-product management for industrial biomass co-combustion. Brussels: EU/JOULE; 1999. Contract No.: JOF3-CT95-0010.

[5] Bale CW, Chartrand P, Degterov SA, Eriksson G, Hack K, Ben Mahfoud R, et al. FactSage Thermochemical Software and Databases. CALPHAD, 2002, 26,189-228.

[6] Becidan M, Sørum L, Frandsen F, Pedersen AJ. Corrosion in waste-fired boilers: A thermodynamic study. Fuel, 2009, 88, 595-604.

[7] Zevenhoven-Onderwater M. Ash-Forming Matter in Biomass Fuels. PhD Thesis, Turku: Åbo Akademi, 2001. 
[8] Tortosa Masiá AA, Buhre BJP, Gupta RP, Wall TF. Use of TMA to predict deposition behaviour of biomass fuels. Fuel, 2007, 86, 2446-56.

[9] Baxter L.L, Miles sr TR, Miles jr TR, Jenkins BM, Milne T, Dayton D, Bryers R, Oden LL. Alkali deposits found in biomass boilers. The behavior of inorganic material in biomass-fired power boilers: field and laboratory experiences. Report NREL/TP-433-8142, SAND96-8225, 1996.

[10] Gill RA. Fillers for papermaking. Retrieved March 2013. URL: www.specialtyminerals.com/fileadmin/userupload/smi/publications/S-PA-AT-PB-42.pdf \

[11] [Baxter LL, Miles TR, Miles Jr TR, Jenkins BM, Milne T, Dayton D, Bryers RW, Oden LL. The behavior of inorganic material in biomass-fired power boilers: field and laboratory experiences. Fuel Proc Tech, 1998, 54, 47-78.

[12] Jiménez S, Ballester J. Effect of co-firing on the properties of submicron aerosols from biomass combustion. Proc Comb Inst, 2005, 30, 2965-72.

[13] Jiménez S, Ballester J. Influence of operating conditions and the role of sulfur in the formation of aerosols from biomass combustion. Comb Flame, 2005, 140, 346-58.

[14] Christensen KA, Stenholm M, Livbjerg $\mathrm{H}$. The formation of submicron aerosol particles, $\mathrm{HCl}$ and SO2 in straw-fired boilers. J Aerosol Sci, 1998, 29, 421-44.

[15] Li B. Modelling of fireside deposit formation in two industrial furnaces. PhD thesis. Turku: Åbo Akademi, 2013.

[16] Hansen PFB. Deposit Formation in the Convective Path of a Danish 80MWth CFB-Boiler CoFiring Straw and Coal for Power Generation. In: Gupta RP, Wall TF, Baxter L, eds. Impact of Mineral Impurities in Solid Fuel Combustion. Springer; 1999:417-431.

[17] Lindberg D, Niemi J, Engblom M, Yrjas P, Laurén T, Hupa M. Effect of temperature gradient on composition and morphology of synthetic chlorine-containing biomass boiler deposits. Fuel Process Technol, 2016, 141, 285-98.

[18] $\mathrm{Du} \mathrm{H}$. Thermodynamic assessment of the $\mathrm{K}_{2} \mathrm{SO}_{4}-\mathrm{Na}_{2} \mathrm{SO}_{4}-\mathrm{MgSO}_{4}-\mathrm{CaSO}_{4}$ system. $\mathrm{J}$ Phase Equilib, 2000, 1, 6-18.

[19] Jensen PA, Zhou H, Žbogar A, Hansen J, Frandsen FJ, Glarborg P, Madsen M, Stang H. Final Report - Ash deposit formation and removal in biomass-fired boilers. Fundamental data provided with deposit probes. Energinet.DK Research PSO Project 4106. Technical University of Denmark. Report nr. R0603. 
[20] Skrifvars B-J, Hupa M, Backman R, Hilturnen M. Sintering mechanisms of FBC ashes. Fuel, 1994, 73, 171-6.

[21] Moradian F, Pettersson A, Richards T. Thermodynamic equilibrium model applied to predict the fouling tendency in a commercial fluidized-bed boiler, combusting solid waste. Energ Fuel, 2015, 29, 3483-94.

This chapter is based on an earlier published article:

Stam AF, Haasnoot K, Brem G. Superheater fouling in a BFB boiler firing wood-based fuel blends. Fuel, 2014, 135, 322-31. 


\section{$7 \quad$ CHROMIUM SPECIATION IN COAL AND BIOMASS CO- COMBUSTION PRODUCTS}

\subsection{Introduction}

Knowledge of the speciation of elements in flue gases and ashes of coal-fired power plants is vital for the understanding of combustion processes and the prediction of operational, environmental and health effects. The European Waste Catalogue (EWC) demands that pulverized fuel fly ash (PFA) from co-combustion be investigated as to its toxicological properties according to the presence and levels of the compounds in coal fly ash. Furthermore, leaching of $\mathrm{Cr}$ in PFA could be a problem if it is used in road construction. In particular, $\mathrm{Cr}(\mathrm{VI})$ is leachable whereas $\mathrm{Cr}(\mathrm{III})$ is not so, and $\mathrm{Cr}(\mathrm{VI})$ is carcinogenic and more toxic than $\mathrm{Cr}(\mathrm{III})$, causing nose bleeding, ulcer, visceral damage, inflamed skin, festering, lung cancer and even death [1], [2]. $\mathrm{Cr}(\mathrm{VI})$ is leachable whereas $\mathrm{Cr}(\mathrm{III})$ is not so, and $\mathrm{Cr}(\mathrm{VI})$ is carcinogenic and more toxic than $\mathrm{Cr}(\mathrm{III})$, causing nose bleeding, ulcer, visceral damage, inflamed skin, festering, lung cancer and even death [1], [2].

Other methods than XAFS exist for determining trace element speciation. However, these methods often require concentrations in the range of percentages, which is not the case for trace elements ( $\mathrm{Cr}$ concentrations in ash from Dutch coal-fired plants are typically around $120 \mathrm{mg} / \mathrm{kg}$ ). Also, they require extraction with water and, due to subsequent reactions, introduce uncertainty. Conversely, direct determination of the oxidation state and chemical speciation of trace elements in the solid state can be done with XAFS spectroscopy. This technique has the ability to focus on a specific element in a material and to provide detailed information relevant to the local bonding and structure of the element in the material, from which the form of occurrence can usually be deduced. Furthermore, this technique is both direct and non-destructive. It was demonstrated that XAFS spectroscopy may be the best technique available for investigating the forms of occurrence of most trace elements in coal and related materials [3].

In this chapter, XAFS measurements are presented for combustion ashes resulting from coal and co-fired secondary fuels along with equilibrium calculations. Not only ash samples from pulverized fuel combustion, but also samples from gasification and fluidized bed combustion are evaluated to take into account extremes of oxygen content in the flue gas, and pure biomass as fuel. Extra information is obtained from leaching tests and relative enrichment factors. The combined approach is used in which thermodynamic calculations, leaching and RE-factors are expected to support and explain the XAFS results. With these combined results, it is expected that more knowledge on the formation process of trace element speciation can be gained. This is very relevant as it a) increases useful interpretation of equilibrium results, e.g. for ashes resulting from fuel composition not evaluated with XAFS, and b) reveals operating parameters with which plant operators can control speciation into less serious forms for environmental and operational concerns. Identified influencing parameters on the formation processes of $\mathrm{Cr}$ compounds may be 
applicable to formation processes of other (trace) element compounds. In literature, thermodynamic equilibrium calculations are reported predicting $\mathrm{Cr}$ speciation for combustion of coal [4], pulverized fuel [5] and coal with co-firing wood [6] but results have not been compared with XAFS measured data in these studies. Moreover, the studies focus on gaseous $\mathrm{Cr}$, but not on the stabilization of $\mathrm{Cr}(\mathrm{VI})$ as solid compounds.

A limited amount of X-ray absorption results have been presented in the past, see [3] and [7] [9], showing a variation in $\mathrm{Cr}(\mathrm{VI})$ concentration with different coal ashes, produced at different plants. Huffman et al. [3] found $>95 \% \mathrm{Cr}$ (III) in the ashes of Pittsburgh \#8 and Illinois \#6 coal produced in a drop tube furnace. Clearly, the $\mathrm{Cr}$ (III) was not chromium oxide. It was presumed to be $\mathrm{Cr}$ (III) incorporated in an aluminosilicate slag, but that could not be decisively concluded. Huggins et al. [7] found $\mathrm{Cr}(\mathrm{VI})$ levels in ten fly ash and three bottom ash samples from power stations to be at or below the detection limit, approximately $3-5 \%$ of total chromium. Two fly ash samples from Israeli power stations had $\mathrm{Cr}(\mathrm{VI})$ levels of 10 and $19 \%$ of total chromium. Shoji et al. [8] found with XANES that $9-26 \%$ of the total chromium was $\mathrm{Cr}(\mathrm{VI})$ in fly ash from several coals from the western USA (except for very fine particles $(<0.1 \mu \mathrm{m})$ in which $\operatorname{Cr}(\mathrm{VI})$ was undetectable); in fly ashes of the eastern USA only $\operatorname{Cr}($ III) was found. Galbreath and Zygarlicke [9] found $\mathrm{Cr}(\mathrm{III})$ in the PM2.5 fraction of Illinois \#6 amounted to $94 \%$ of the total chromium, while in the PM2.5 fraction of Absaloka (a western USA coal), it was only $57 \%$.

\subsection{Experimental and modelling}

\subsubsection{Samples}

Different ash samples resulting from Dutch power plants have been investigated by the authors with XAFS. The samples result from pf combustion, fluidized bed combustion, coal gasification and fluidized bed gasification. The pf combustion ash samples are gathered from the bottom ash hopper and from the electrostatic precipitator (ESP) hoppers. In this chapter, abbreviations are used: $7-9 \%$ MBM-mix represents a mix of meat and bone mill (MBM) and a variety of other biomass; $18 \%$ MBM-mix represents a mix of MBM, wood, cacao residue and a variety of other biomass; $21 \%$ sheanut mix represents a mix of sheanut residue, palm kernels and cacao residue. The co-firing percentages are - in this chapter - always on basis of thermal heat input. Detailed results are presented in Table 7.1 and Appendix 7A, Tables 7.A.1. to 7.A.3. 
Table 7.1 Samples.

\begin{tabular}{|c|c|c|c|}
\hline coal & secondary fuel & type of sample* & $\begin{array}{l}\mathrm{Cr}(\mathrm{VI}) / \\
\mathrm{Cr}_{\text {total }}(\%)\end{array}$ \\
\hline blend & & PFA & 6 \\
\hline blend & & PFA-C & 6 \\
\hline blend & & PFA-5 & 8 \\
\hline blend & none & PFA-C & 7 \\
\hline blend & & BA & 5 \\
\hline blend & & PFA-C & 6 \\
\hline blend & & PFA-4 & 9 \\
\hline \multirow{3}{*}{ blend } & \multirow{2}{*}{ 7\% MBM mix } & PFA-C & 4 \\
\hline & & PFA-5 & 2 \\
\hline & $9 \%$ MBM mix & PFA-C & 3 \\
\hline \multirow{3}{*}{ blend } & \multirow{3}{*}{ 18\% MBM mix } & $\mathrm{BA}$ & 2 \\
\hline & & $\mathrm{PFA}<\mathrm{deNO}^{* *}$ & 4 \\
\hline & & PFA-C & 4 \\
\hline & $10 \% \quad$ municipal & & \\
\hline Polish & sewage sludge & PFA-C & 4 \\
\hline \multirow{4}{*}{ blend } & \multirow{4}{*}{$21 \%$ sheanut mix } & PFA-1 & 6 \\
\hline & & PFA-2 & 6 \\
\hline & & PFA-3 & 6 \\
\hline & & PFA-4 & 6 \\
\hline \multirow{3}{*}{ blend } & $7 \%$ wood & PFA-C & 16 \\
\hline & $15 \%$ wood & PFA-C & 13 \\
\hline & $28 \%$ wood & PFA-C & 12 \\
\hline none & $\begin{array}{l}\text { municipal sewage } \\
\text { sludge }\end{array}$ & CFB filter ash & 4 \\
\hline \multirow{2}{*}{$\begin{array}{l}\text { none } \\
\text { none }\end{array}$} & \multirow{2}{*}{ pruning, wood } & BFB filter ash & 29 \\
\hline & & BFB filter ash & 41 \\
\hline SAf/Col & none & CG-fly ash & 0 \\
\hline \multirow{2}{*}{ Colombian } & none & CG-fly slag & 0 \\
\hline & none & CG-fly ash & 0 \\
\hline Colombian & $20 \%$ wood & CG-fly ash & 0 \\
\hline none & demolition wood & BFBG cyclone ash & 3 \\
\hline
\end{tabular}

${ }^{*}$ PFA = Pulverized fuel Fly Ash; -X denotes ESP hopper 1-5 or C for Collection tank. BA = bottom ash. $\mathrm{CFB}=$ Circulating Fluidized Bed. BFB = bubbling fluidized bed. CG = Coal Gasification . $\mathrm{BFBG}=$ Bubbling Fluidized Bed Gasifier ${ }^{* *}$ PFA sampled upstream deNOx 


\subsubsection{XAFS}

Chromium XAFS spectroscopy was conducted on samples of fly-ash at beam-lines 10-2 and 4-3 of the Stanford Synchrotron Radiation Lightsource (SSRL), Stanford University, CA. Samples (approximately 1 to $3 \mathrm{~g}$ ) were suspended in the synchrotron X-ray beam by means of small baggies $(\sim 4 \mathrm{x} \sim 5 \mathrm{~cm})$ made from ultrathin $(\sim 5 \mu \mathrm{m})$ polycarbonate film. Measurements were made in fluorescence geometry utilizing either a 13-channel Ge detector (beamline 10-2) or a 4channel $\mathrm{Si}(\mathrm{Li})$ detector (beamline 4-3) to measure the X-rays fluoresced by chromium in response to the X-ray absorption process. To maximize the useful signal, each channel in the detector was gated to accept only X-rays of energy within a $\pm 400 \mathrm{eV}$ window of the chromium fluorescent $\mathrm{Ka} X$-ray energy at $5,410 \mathrm{eV}$. Soller slits and a $6 \mu$ vanadium filter were also used to enhance the signal/noise ratio of the fluorescent X-rays [10]. Typically, each spectrum was collected between three and six times and the final spectrum was an average of the individual scans. Primary energy calibration was achieved by measurement of the spectrum of chromium foil alternately with the measurement of the XAFS spectrum of the ash. Analysis of the chromium XAFS spectra of the combustion products consisted of the basic processing steps [11], [12] using the program SIXPack [13], part of IFEFFIT package for XAFS data analysis [14]. First, the energy scale was adjusted according to the position of the absorption edge energy defined by chromium foil and the individual scans for each sample were averaged. The pre-edge and post-edge slopes were then defined and the spectra were normalized to the difference in absorption (step-height) between the two. At this point, the spectra were divided into separate X-ray absorption near-edge structure (XANES) and extended X-ray absorption fine structure (EXAFS) regions. Owing to the presence of significant L-edges for $\mathrm{Cs}$ and $\mathrm{La}$ at about 170 and $250 \mathrm{eV}$ above the chromium $\mathrm{K}$ absorption edge in all fly-ash spectra, the chromium EXAFS region was effectively rendered unanalysable and no attempt was made to analyse this region. Estimation of the $\mathrm{Cr}(\mathrm{VI})$ contents from the chromium XANES spectra was based on the method outlined previously [7]. The mentioned detection limits and uncertainties mentioned in [7] were conservative estimates in 1999. Improvements since then in detector technology and sensitivity, in synchrotron brightness, and in the availability of wiggler-enhanced beam-lines for environmental studies have made the $\mathrm{Cr}(\mathrm{VI})$ XANES method considerably more precise. An updated estimate of the detection limit and uncertainties would be $2 \%$ and $\pm 2 \%$, respectively.

\subsubsection{Leaching}

For leaching, the Dutch availability test $(L / S=100)$ was used, reflecting what possibly can leach under extreme conditions. A grind sample is used with $95 \%$ of the dry matter $<125 \mu \mathrm{m}$. A twostep extraction is performed with water (both $L / S=50$ ) in a shaking batch test. In the first step, the $\mathrm{pH}=7$, in the second $\mathrm{pH}=4$ (controlled with $\mathrm{HNO}_{3}$ ). By dividing the ratio of leached $\mathrm{Cr}$ per sample with the $\mathrm{Cr}$ concentration in the fuel ash sample, the availability is determined. $\mathrm{The} \mathrm{Cr}$ concentration in the fuel ash sample is determined by ICP (after digestion with acid mixture). The 
leaching test was chosen according to Dutch and European regulations, and performed according to and described in standard [15].

\subsubsection{RE-factors}

In general, the combustion ash contains the same elements as were present in the fuel, but enriched in the ash by a factor equal to $100 /($ ash content in \%). However, the enrichment in the ash depends on the type of ash and the particular element. The term "relative enrichment" (RE) was introduced to properly describe the behaviour observed, see [16], [17]. The RE factor is defined as:

$R E(x)=\frac{\text { concentration in the ash of element } x}{\text { concentration in the fuel element } x} \cdot \frac{\text { ash content in } \%}{100}$

Further discussion can be found elsewhere: [18], [17].

\subsubsection{Thermodynamic equilibrium calculations}

Thermodynamic equilibrium calculations were conducted with FactSage (see [19] or a general description) which includes an extensive component database as well as sophisticated models to describe the non-ideal behaviour of glass (slag).

Heating rates in pulverized fuel (pf) boilers are high $\left(10^{3}-10^{5} \mathrm{~K} / \mathrm{s}\right)$ whereas particles and flue gases in modern boilers have a residence time of about 3 seconds (in the first draft of the boiler). Hence, the equilibrium state is not (completely) reached in boiler processes, and kinetics play a significant role. Kinetic constraints can partly be taken into account by selecting components from the database that can be realistically expected in combustion products (based on practical experiences). The presence and quality of the thermodynamic data plays an important role, as is outlined in this chapter, e.g. with respect to chromates. Equilibrium calculations are currently the sole method to simulate the complex boiler chemistry taking in account all relevant elements simultaneously. The mode of occurrence of elements in the fuel plays an important role in their fate. This means that in calculations, the availability of elements for reaction has to be translated into calculation input, see [6], [20].

In the calculations, a pressure of 1 atm., a temperature range of 350 to $1,700{ }^{\circ} \mathrm{C}$, and typical air excess ratios $(\lambda)$ of $0.8,1.0$ and 1.16 were considered in the equilibrium calculations. Details on the considered $\mathrm{Cr}$ species, ash and flue gas compositions considered are shown in Appendix 7B, Tables 7.B.1 and 7.B.2. 


\subsection{Results}

\subsubsection{XAFS measurements}

Our measurements show that the major fraction of $\mathrm{Cr}$ in fly ash is $\mathrm{Cr}(\mathrm{III})$, the rest is the more toxic $\mathrm{Cr}(\mathrm{VI})$. Results are summarized in Table 7.1; as an example, spectroscopic data for two analysed samples are given in Appendix 7A, Figure 7.A.1. The fly ashes resulting from pure coal combustion show a $\mathrm{Cr}(\mathrm{VI})$ content of $7 \pm 1.3 \%(\mathrm{n}=6)$, fly ashes from pf combustion of coal and cocombustion of various biomass (MBM, cacao residue, palm kernels, et cetera) show a $\mathrm{Cr}(\mathrm{VI})$ content of $7 \pm 3.9 \%(n=16)$. For co-combustion of $7-28 \%$ wood, $\operatorname{Cr}(\mathrm{VI})$ percentages of the total chromium in the range of $12-16 \%$ were measured. Elevated levels of $\mathrm{Cr}(\mathrm{VI})$ have also been experienced with firing clean wood in a CFB boiler (29 and 41\%). Very low fractions of $\mathrm{Cr}(\mathrm{VI})$ were found in gasifier ash resulting from coal gasification and even with $20 \%$ co-gasification of wood the fraction of $\mathrm{Cr}(\mathrm{VI})$ is negligible. Also in the single bubbling fluidized bed gasifier sample (pure wood), a relatively low percentage of $3 \% \mathrm{Cr}(\mathrm{VI})$ (of total $\mathrm{Cr}$ ) was found. At a plant where $21 \%$ sheanut mix was co-fired, samples have been taken from ESP hoppers 1, 2, 3 and 4 with hopper 4 containing the smallest particles. In all samples the $\mathrm{Cr}(\mathrm{VI})$ content (of total $\mathrm{Cr}$ ) was $6 \%$ so no conclusion can be drawn that $\mathrm{Cr}(\mathrm{VI})$ would be enriched in smaller particles.

In our XAFS measurement results, the dominant chemical form of chromium is most likely $\mathrm{Cr}$ (III) in aluminosilicate glass in the seven coal combustion samples, as well as in all the coal with biomass co-fired cases (7-9 and $18 \%$ of MBM mix, $10 \%$ municipal sewage sludge). On the other hand, $\mathrm{Cr}(\mathrm{III})$ in the fluidized bed filter ash from municipal sewage sludge combustion and cyclone ash from demolition wood gasification is in the spinel phase, $\left[(\mathrm{Fe}, \mathrm{Mg})(\mathrm{Fe}, \mathrm{Al}, \mathrm{Cr})_{2} \mathrm{O}_{4}\right]$. The form of $\mathrm{Cr}$ in the ash resulting from $20 \%$ wood co-gasification with coal (containing negligible amounts of $\mathrm{Cr}(\mathrm{VI})$ ) was found to be either sulphide or metallic chromium. In coal gasification ash, all $\mathrm{Cr}$ appeared to be $\mathrm{Cr}(\mathrm{III})$, present as sulphate and sulphide, in addition to $\mathrm{Cr}$ (III) in aluminosilicate glass.

\subsubsection{Leaching}

The leachable $\mathrm{Cr}$ fraction varies from 1.0 to $15 \mathrm{mg} / \mathrm{kg}$ (specified Appendix 7A, Table 7.A.1). When comparing these values with the $\mathrm{Cr}(\mathrm{VI})$ content (of total $\mathrm{Cr}$ ) - which vary from 2 to 16 $\mathrm{mg} / \mathrm{kg}$ - that ratio varies from $25-100 \%$. $\mathrm{Cr}(\mathrm{VI})$ is very water soluble, whereas $\mathrm{Cr}(\mathrm{III})$ is relatively water insoluble. Some of the leached $\mathrm{Cr}$ may have been $\mathrm{Cr}(\mathrm{III})$. What these ratios nevertheless indicate is that some of the $\mathrm{Cr}(\mathrm{VI})$ is leachable and some is not. For some samples, no leaching tests were performed. 


\subsubsection{Relative Enrichment factors}

The average $\mathrm{RE}$ factors of $\mathrm{Cr}$ have been determined for the different ash fractions on a series of $\mathrm{n}$ measurements (in order of decreasing particle size): bottom ash $(0.91, \mathrm{n}=22)$, ESP hopper 1 $4(0.87,1.01,1.21,1.21, \mathrm{n}=8)$ and fly ash collected downstream of the $\operatorname{ESP}(1.75, \mathrm{n}=12)$. The RE-factors are around 1 . The higher the volatility of the element, the greater is the range in RE value between the bottom ash and the fly ash collected downstream of the ESP. The latter are the smallest particles with the highest specific surface area on which the volatile elements will condense or react with.

\subsubsection{Thermodynamic calculation results}

Chromium speciation is investigated for different fuel compositions, matching those of the measurements. Thermodynamic stability is very alike for the different fuels. Notably, typical maximum flue gas temperatures in pf boilers and coal gasifiers are $>1,500{ }^{\circ} \mathrm{C}$, whereas in fluidized bed boilers they are around $900{ }^{\circ} \mathrm{C}$. Under both reducing and oxidizing conditions chromium gas phases are stable above $1,400-1,500{ }^{\circ} \mathrm{C}$. However, for reducing conditions - as in the flames - the temperature above which gas phases are stable is higher and in addition, much solid $\mathrm{Cr}$ (III) compound is stable above $1,550{ }^{\circ} \mathrm{C}$. With $3 \%$ excess oxygen in the dry flue gases (equivalence ratio $\lambda=1.16$ ) higher oxidation state gas phases are stable above $1,450{ }^{\circ} \mathrm{C}$ as $\mathrm{CrO}_{3}(\mathrm{~g})$ and $\mathrm{CrO}_{2}(\mathrm{~g})$, see Figure 7.1. Lower oxygen contents induce stable phases as $\mathrm{CrO}_{2}(\mathrm{~g}), \mathrm{CrO}(\mathrm{g})$ and $\mathrm{Cr}(\mathrm{g})$. Solid $\mathrm{Cr}$ phases condense below $1550{ }^{\circ} \mathrm{C}$, dependent on the oxygen level with valence $\mathrm{Cr}(\mathrm{VI})$ as $\mathrm{BaCrO}_{4}(\mathrm{~s})$, or $\mathrm{Cr}(\mathrm{III})$ as chromium oxide $\left(\mathrm{Cr}_{2} \mathrm{O}_{3}(\mathrm{~s})\right)$ or chromite $\left(\mathrm{FeO} \cdot \mathrm{Cr}_{2} \mathrm{O}_{3}(\mathrm{~s})\right)$.

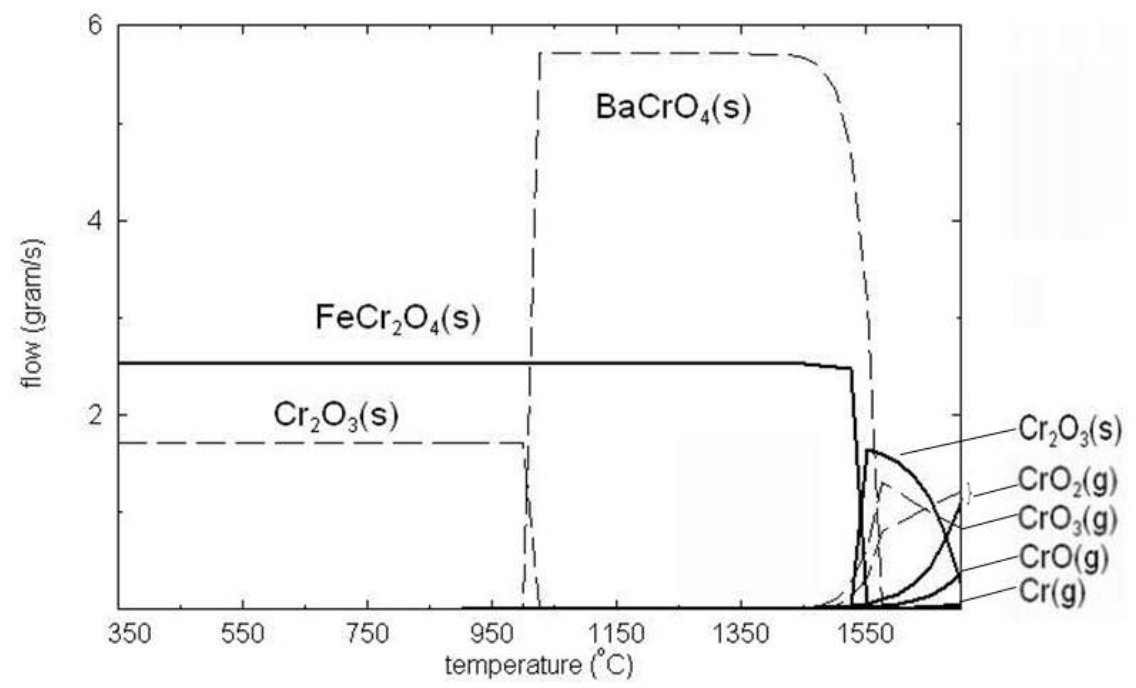

Figure 7.1 Chromium speciation (thermodynamic equilibrium) with coal and $18 \%$ of co-firing MBM-mix, $\lambda=1.3$ (dashed), $\lambda=0.8$ (solid). 
Below $1,000{ }^{\circ} \mathrm{C}$ mostly solid $\mathrm{Cr}(\mathrm{III})$ compound is stable under both oxidizing and reducing conditions. Specifically with higher $S$ content in the fuel (i.e. coal firing) chromium sulphate $\left(\mathrm{Cr}_{2}\left(\mathrm{SO}_{4}\right)_{2}(\mathrm{~s})\right)$ is stable below $500{ }^{\circ} \mathrm{C}$ (not shown in figure). With more than $50 \%$ of co-fired wood, barium chromate is also stable below $700{ }^{\circ} \mathrm{C}$ (in stead of $\mathrm{Cr}_{2} \mathrm{O}_{3}(\mathrm{~s})$ as in Figure 7.1).

\subsection{Discussion}

\subsubsection{Comparison of calculations with measurements}

Gaseous $\mathrm{Cr}$ is stable only at very high temperatures (i.e. $>1,400{ }^{\circ} \mathrm{C}$ ), meaning there is only a very short span of time in which $\mathrm{Cr}$ can evaporate. This is in line with the measured RE-factors of $\mathrm{Cr}$ being around 1 with a very modest increase from just below 1 to just above 1 with decreasing particle size (see section 7.3). The $\mathrm{Cr}(\mathrm{VI})$ percentages do not differ with the different particle size fractions (see measurements in section 7.3.1 and in [8]). This is in line with the calculations showing similar volatility of $\mathrm{Cr}(\mathrm{III})$ and $\mathrm{Cr}(\mathrm{VI})$ : when gaseous $\mathrm{Cr}(\mathrm{VI})$ is present, it is present in the same temperature range as gaseous $\mathrm{Cr}(\mathrm{III})$.

For two cases, the air stoichiometry was as follows. The measured $\mathrm{O}_{2}$ level at the outlet boiler (but before air preheater) was $4.1 \%$ at the plant when $21 \%$ sheanut mix was co-fired. The level measured in the plant when $18 \%$ MBM mix was co-fired, was much lower: $1.9 \% \mathrm{O}_{2}$. The levels correspond to unburnt carbon contents in the fly ash of ca. 4 and $6 \%$ respectively and $\mathrm{CO}$ concentrations in the flue gas differing by more than a factor of 10 . A lower $\mathrm{Cr}(\mathrm{VI})$ percentage would be expected according to the calculation results in the plant with the low $\mathrm{O}_{2}$ partial pressure in the flue gas. This was indeed found: $4 \%$ instead of $6 \% \mathrm{Cr}(\mathrm{VI})$ of total $\mathrm{Cr}$ (in two and four samples respectively). Extrapolating the trend, almost no $\mathrm{Cr}(\mathrm{VI})$ would be expected in the coal gasification ash in which $\lambda<0.3$. This was also observed (see section 7.3).

The measurements show that for co-firing 7-9\% MBM mix, 18\% MBM mix, 10\% municipal sewage sludge and $21 \%$ sheanut mix, the $\mathrm{Cr}(\mathrm{VI})$ percentages are equal to or lower than those for pure coal firing. However, with $7-28 \%$ co-combustion of wood and $100 \%$ wood combustion (in a $\mathrm{BFB}$ ), the $\mathrm{Cr}(\mathrm{VI})$ percentages are higher: $12-41 \%$ (of total $\mathrm{Cr}$ ) compared to about $7 \%$ with pure coal firing. The measured oxygen content in the flue gas with co-firing wood was $4 \%$ at the outlet boiler (but before the air preheater), similar to the content when sheanut, palm kernel and cacao residue was co-fired. This indicates that the $\mathrm{Cr}(\mathrm{VI})$ fraction may not only be related to operating conditions (i.e. oxygen content) but also to the fuel composition. Thermodynamic calculations have been performed for 7 and $15 \%$ wood co-firing, analogous to the levels at which the ashes under investigation were produced, and also for $38.5 \%$ wood co-firing to see the trend with increasing co-firing percentage. It was observed that $\mathrm{Cr}$ speciation does not change above 1,000 
${ }^{\circ} \mathrm{C}$ when the wood co-firing percentage is increased from 7 to $38.5 \%$. Below $700{ }^{\circ} \mathrm{C} \mathrm{Cr}(\mathrm{VI})$ is more stable than $\mathrm{Cr}(\mathrm{III})$ with the increased wood percentage.

\subsubsection{Comments on thermodynamic calculations}

Barium chromate is a very stable component. Nevertheless, molar ash concentrations of $\mathrm{Ca}, \mathrm{Mg}$, $\mathrm{Fe}, \mathrm{K}$ and $\mathrm{Na}$ are normally much higher than that of $\mathrm{Ba}$, so chromates could be formed with those elements as well. Also Shoji et al. [8] mention $\mathrm{Ca}-\mathrm{Cr}^{6+}-\mathrm{O}$ complexes as a possibility since much carboxyl bound (and thus readily vaporizable) calcium is present in western US coals and lignites. Leaving out barium chromate as a possible calculation result, sodium and potassium chromate appear. Data for other chromates is not available in the FactSage database.

$\mathrm{Cr}(\mathrm{III})$ was also found in the slag. FactSage includes a slag phase in which $\mathrm{CrO}$ and $\mathrm{Cr}_{2} \mathrm{O}_{3}$ are incorporated, but $\mathrm{Cr}(\mathrm{VI})$ not, so the latter cannot be predicted. In addition, $\mathrm{Cr}$ is stable as a slag componwent when the $\mathrm{Cr}$-containing slag is selected in the result list (12 slags are included in FactSage 5.5). This confirms measurements presented by [6], [3] and those in this chapter. [6] shows an even $\mathrm{Cr}$ distribution in cross cut glass particles.

Following the calculation results, it is likely that the formation of $\mathrm{Cr}(\mathrm{VI})$ is a high temperature process (maximum flue gas temperatures in pf boilers are $>1,500{ }^{\circ} \mathrm{C}$ ). This is supported by the findings of [21] and [22]. The increased thermodynamic stability below $700{ }^{\circ} \mathrm{C}$ of $\mathrm{Cr}(\mathrm{VI})$ compounds with the increase of the wood co-firing percentage is not likely to be an explanation for the measured higher $\mathrm{Cr}(\mathrm{VI})$ level. Namely, similar calculation results were found for high cofired levels of sheanut mix and for high levels of wood co-firing whereas the measured $\mathrm{Cr}(\mathrm{VI})$ levels are much different. Possible causes for the measured higher $\mathrm{Cr}(\mathrm{VI})$ levels with co-firing wood is given in next section.

\subsubsection{Formation of $\mathrm{Cr}$ combustion products}

The presence of $\mathrm{Cr}(\mathrm{VI})$ in combustion ash could be explained by its presence in coal or wood and remaining unchanged during combustion. However, in coal, $\mathrm{Cr}$ is normally present as $\mathrm{Cr}(\mathrm{III})$, as appeared from different research, e.g. [23] and [24]. An exceptional case was presented by [25]. They found $\mathrm{Cr}(\mathrm{VI})$ in the form of crocoite $\left(\mathrm{PbCrO}_{4}\right)$ in a New Zealand coal from an unusual geological formation. $\mathrm{Cr}(\mathrm{III})$ is more stable than $\mathrm{Cr}(\mathrm{VI})$ and when $\mathrm{Cr}(\mathrm{VI})$ forms are brought into the environment by humans, it reverts to $\mathrm{Cr}(\mathrm{III})$. Hence, in biomass such as wood, $\mathrm{Cr}$ is probably present as the more stable $\mathrm{Cr}(\mathrm{III})$ as it is a natural product. The $\mathrm{Cr}(\mathrm{VI})$ found in byproducts must therefore be a result of the combustion process. 
The association of $\mathrm{Cr}$ in the fuel could nevertheless influence its fly ash speciation: the organically associated $\mathrm{Cr}$ will more easily evaporate. This was shown in [23] where especially the Wyodak coal with mainly organically associated $\mathrm{Cr}$ showed a higher value of vaporized $\mathrm{Cr}$ than could be expected on basis of the $\mathrm{Cr}$ concentration in the coal. When present in biomass the organically bound fraction is higher in general, which will promote the evaporation of $\mathrm{Cr}$.

Aside from the organically bound $\mathrm{Cr}$ form, $\mathrm{Cr}$ is shown to be associated with clay minerals, more specific illite [23], [9]. Illite partially melts during coal combustion and forms a glass phase. As $\mathrm{Cr}(\mathrm{III})$ is predominantly found $\mathrm{n}$ the aluminosilicate glass phase, a straightforward explanation is that clay bound $\mathrm{Cr}$ is incorporated in the glass phase during melting, see Figure 7.2. In equilibrium, chromium in oxide forms, either as $\mathrm{Cr}_{2} \mathrm{O}_{3}$ or as $\mathrm{FeCr}_{2} \mathrm{O}_{4}$, shows stability up to very high temperatures and as such is believed to remain unaltered during combustion if $\mathrm{Cr}$ is present in such forms in the fuel. Presence of $\mathrm{FeCr}_{2} \mathrm{O}_{4}$, especially in coals enriched in $\mathrm{Cr}$, was indicated by [26], [27].

Figure 7.2 gives a schematic overview of conversion pathways for chromium, based on the results found in this study. Chromium ends up as $\mathrm{Cr}(\mathrm{III})$ or (non-)leachable $\mathrm{Cr}(\mathrm{VI})$.

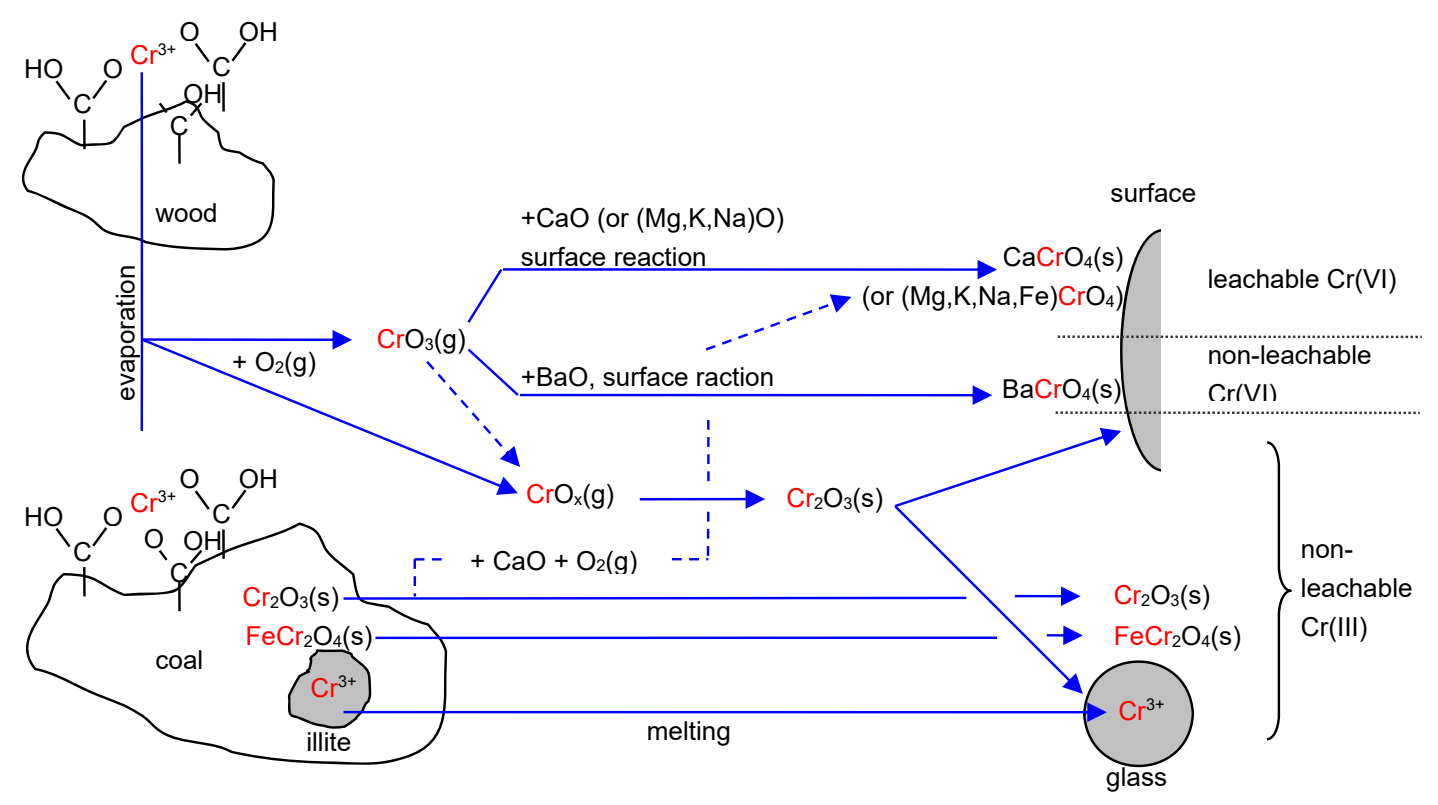

Figure 7.2 Possible reaction mechanisms for the formation of leachable and non-leachable $\mathrm{Cr}(\mathrm{VI})$ and non-leachable $\mathrm{Cr}(\mathrm{III})$.

Our equilibrium calculations suggest a partial volatilization of $\mathrm{Cr}$, which is the more loosely, i.e. organically, bound $\mathrm{Cr}$ (opposite to $\mathrm{Cr}$ associated with illite or present as oxide or spinel which is 
less loosely bound). Dependent on the local oxygen content $\mathrm{CrO}_{3}(\mathrm{~g})$ may be formed, or lower oxidation state forms of gaseous $\mathrm{Cr}$. The latter are likely to form chromium oxide, condensing already at high temperature $\left(>1,500{ }^{\circ} \mathrm{C}\right)$. A possible reaction scheme is that $\mathrm{CrO}_{3}(\mathrm{~g})$ is stabilized with free lime by $\mathrm{CrO}_{3}(\mathrm{~g})+\mathrm{CaO}(\mathrm{s}) \rightarrow \mathrm{CaCrO}_{4}(\mathrm{~s})$. This hypothesis is supported by our measurements, although not extensively many, correlating the $\operatorname{Cr}(\mathrm{VI})$ percentage with the free lime content in the ash (Figure 7.3). This hypothesis is also proposed by Dong et al. [28] on basis of tests with co-firing tannery sludge. In fact, effective methods to suppress $\mathrm{Cr}(\mathrm{VI})$ formation are enhancing interaction of free $\mathrm{CaO}$ with $\mathrm{Si} / \mathrm{Al}$ - or $\mathrm{P}$-compounds or separating Ca-rich compounds from the fuel, [29], [30]. It is stressed that the reaction is assumed to occur with free lime. This also explains the reason that no higher $\mathrm{Cr}(\mathrm{VI})$ percentages have been found with $\mathrm{MBM}$ co-firing, although $\mathrm{Ca}$ levels are high. The calcium is not available since it is bound to phosphate, most likely hydroxyapatite or bio-apatite. We therefore don't support the conclusion in [21] that combustion of biomass in general would favour enrichment of fly ash with water soluble $\mathrm{Cr}(\mathrm{VI})$. Also co-firing tests have been performed in our research with chicken manure in a $1.5 \mathrm{MW}_{\text {th }}$ test boiler. Co-firing 10, 15 and 20\% chicken manure with Colombian coal, resulted in $\mathrm{Cr}(\mathrm{VI})$ percentages of total chromium of 9,14 and $11 \%$, as determined with XAFS. Such values are elevated compared to pure coal firing. It is questionable as to how far test boiler conditions reflect those of large scale plants and therefore they have not been taken into account.

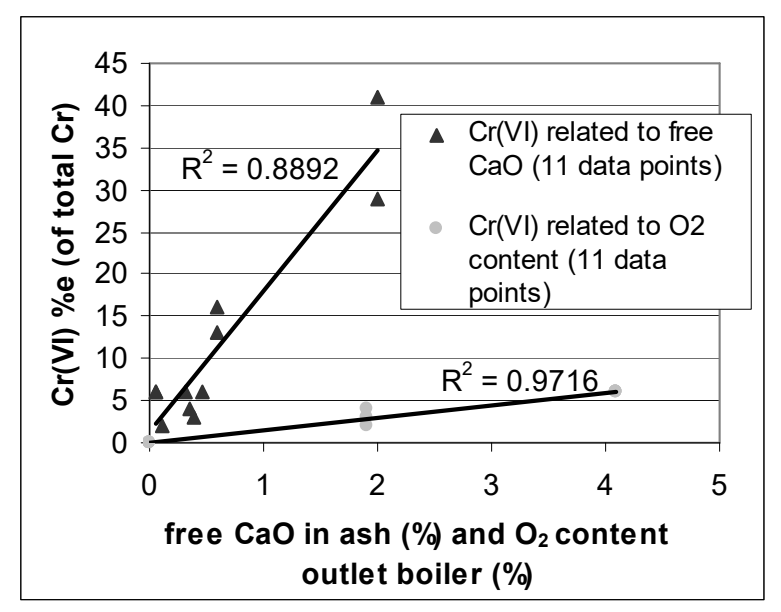

Figure 7.3 Correlation between $\mathrm{Cr}(\mathrm{VI})$ of total $\mathrm{Cr}$ in fly ash and free lime content in fly ash and oxygen content in the flue gas.

Another reaction mechanism involving free lime was proposed by [31] who investigated leachability of $\mathrm{Cr}$ of waste incinerator ash after heating at $990 \pm 10{ }^{\circ} \mathrm{C}$ (to vaporize trace elements). Formation of $\mathrm{CaCrO}_{4}$ was probable and the synthesis reaction $2 \mathrm{Cr}_{2} \mathrm{O}_{3}+4 \mathrm{CaO}+3 \mathrm{O}_{2}$ $\rightarrow 4 \mathrm{CaCrO}_{4}$ was proposed. It must be noticed however that the latter occurred with high residence time ( 1 hour) and due to the fact that the experiments took place in cups, intensive 
contact between particles allowed for surface reactions. These circumstances differ from those in pf boilers. Nevertheless, the reaction route cannot be excluded.

Aside from the reaction with $\mathrm{CaO}, \mathrm{CrO}_{3}(\mathrm{~g})$ may react with other components to form chromate: $\mathrm{BaO}, \mathrm{FeO}, \mathrm{MgO}, \mathrm{K}_{2} \mathrm{O}$ or $\mathrm{Na}_{2} \mathrm{O}$ are possibilities. That different chromates can be formed is supported by the leaching results, indicating forms of $\mathrm{Cr}(\mathrm{VI})$ that are leachable and not leachable. Values from [9] of 25 and $31 \%$ from $\mathrm{PM}_{2.5}$ and $\mathrm{PM}_{2.5+}$ leaching, respectively, lie within this region. This means that a combination of non, less and good soluble chromates is likely to be present. $\mathrm{BaCrO}_{4}$ is insoluble, whereas the solubilities of other chromates of $\mathrm{K}, \mathrm{Na}, \mathrm{Ca}$ and $\mathrm{Mg}$ vary from 4.9 to $238 \mathrm{~g} / \mathrm{l}$ or are indicated as very soluble [32]. The very stable, non-soluble $\mathrm{BaCrO}_{4}$ can account for the low $L / S=100$ values whereas the higher $L / S=100$ values are accounted for by other chromates. In theory, $\mathrm{Cr}(\mathrm{VI})$ may even exist in a glass phase [33] (for fly ash this is not confirmed by any measurement data) which could account for low $L / S=100$ values.

The theory that $\mathrm{Cr}(\mathrm{VI})$ formation is a high temperature process, well in excess of $1000{ }^{\circ} \mathrm{C}$ could be opposed by stating that high $\mathrm{Cr}(\mathrm{VI})$ values (29 and $41 \%$ ) have been found in $\mathrm{FBC}$ ashes whereas the flue gas temperature in an $\mathrm{FBC}$ is limited to about $900{ }^{\circ} \mathrm{C}$. A burning char particle however has its own micro-climate, deviating much from the flue gas conditions with temperatures that can be as high as $2,000{ }^{\circ} \mathrm{C}$ [34]. In addition, the suggestion of [9] relating maceral bound $\mathrm{Cr}(\mathrm{III})$ and oxygen functional groups in subbituminous PRB coals to promotion of $\mathrm{Cr}(\mathrm{VI})$ formation is in line with this formation being a gas phase process.

\section{References}

[1] Toward mechanisms of metal carcinogenesis: biological effects of metals. Fishbein $L$ and Furst A. Eds.; Plenum Press: New York, 1987, pp 295-327.

[2] Basic environmental toxicology. Cockerham LG and Shane BS; CRC Press: Florida, 1994, pp 121-128.

[3] Huffman GP, Huggins FE, Shah N, Zhao J. Speciation of arsenic and chromium in coal and combustion ash by XAFS spectroscopy. Fuel Process Technol, 1994, 39, 47-62.

[4] Frandsen FJ, Dam-Johansen K, Rasmussen P. Trace elements from combustion and gasification of coal - an equilibrium approach. Prog Energy Combust Sci, 1994, 20, 115-38.

[5] Thompson D, Argent BB. Thermodynamic equilibrium of trace element mobilization under pulverized fuel combustion conditions. Fuel, 2002, 81, $345-61$. 
[6] Stam AF, Meij R, Winkel BH te, Cieplik M. Predictions of the speciation of elements in coal ash with thermodynamic equilibrium calculations for advanced techniques in pf-coal-fired power plants co-firing biomass; 32nd International Conference on Coal Utilization \& Fuel Systems, Clearwater, FL, 2007.

[7] Huggins FE, Najih M, Huffman GP. Direct speciation of chromium in coal combustion byproducts by X-ray absorption fine structure spectroscopy. Fuel, 1999, 78, 233-42.

[8] Shoji T, Huggins FE, Huffman GP. XAFS spectroscopy analysis of selected elements in fine particulate matter derived from coal combustion. Energ Fuels, 2002, 16, 325-29.

[9] Galbreath KC, Zygarlicke CJ. Formation and chemical speciation of arsenic-, chromium-, and nickel-bearing coal combustion PM2.5. Fuel Process Technol, 2004, 85, 701-26.

[10] Stern E, Heald S. An X-ray filter assembly for fluorescence EXAFS measurements. Nucl Instrum Methods, 1980, 172, 397-9.

[11] Koningsberger DC, Prins R. Eds. X-ray Absorption. Principles, Applications, Techniques of EXAFS, SEXAFS, and XANES; Wiley: New York, 1988.

[12] Lee PA, Citri, PH, Eisenberger P, Kincaid BM. Extended X-ray absorption fine structure - its strengths and limitations as a structural tool. Rev Mod Phys, 1981, 53, 769-808.

[13] Webb, S.M. SIXPack: a graphical user interface for XAS analysis using IFEFFIT. Phys Scr, 2005, T115, 1011-14.

[14] Ravel B, Newville M. ATHENA, ARTEMIS, HEPHAESTUS: data analysis for X-ray absorption spectroscopy using IFEFFIT. J Synchrotron Rad, 2005, 12, 537-41.

[15] NEN 7371. Leaching characteristics - Determination of the availability of inorganic components for leaching - Solid earthy and stony materials (Published 01-01-2004).

[16] Meij R, Kooij J van der, Sluys JLG van der, Siepman FGC, Sloot HA van der. The emission of fly ash and trace species from pulverized coal fired utility boilers, VIth World Congress on air quality, Paris, 1983; pp 317-324.

[17] Meij R. Trace elements behavior in coal-fired power plants. Fuel Process Technol, 1994, 39, 199-217.

[18] Meij, R. Tracking trace elements at a coal-fired power plant equipped with a wet flue gas desulphurisation facility. Kema Scientific \& Technical Reports, 1989, 7, 267-355. 
[19] Bale CW, Chartrand P, Degterov SA, Eriksson G, Hack K, Ben Mahfoud R, Melançon J, Pelton AD, Petersen S. FactSage Thermochemical Software and Databases. Calphad, 2002, 26, 189-228.

[20] Stam A, Brem G. Slagging Prediction of slagging with enhanced biomass co-firing in Dutch utility boilers using an engineering method; 34th International Conference on Coal Utilization \& Fuel Systems, Clearwater, FL, 2009.

[21] Świetlik R, Trojanowska M, Łożyńska M, Molik A. Impact of solid fuel combustion on valence speciation of chromium in fly ash. Fuel, 2014, 137, $306-12$.

[22] Kato N. Reduction of chromium(VI) elution from coal ash by two-stage combustion method for pulverized coal firing. Bunseki Kagaku, 2015, 64, 125 - 30.

[23] Huggins FE, Shah N, Huffman GP, Kolker A, Crowley S, Palmer CA, Finkelman RB. Mode of occurrence of chromium in four US coals. Fuel Process Technol, 2000, 63, 79-92.

[24] Goodarzi F, Huggins FE. Speciation of Chromium in Feed Coals and Ash Byproducts from Canadian Power Plants burning Subbituminous and Bituminous Coals. Energ Fuel, 2005, 19, 2500-08.

[25] Li Z, Moore TA, Weaver SD, Finkelman RB. Crocoite: an unusual mode of occurrence for lead in coal. Int J Coal Geol, 2001, 45, 289-93.

[26] Brownfield ME, Affolter RH, Stricker GD, Hildebrand RT. High chromium contents in Tertiary coal deposits of northwestern Washington - a key to their depositional history, Int J Coal Geol, 1995, 27, 153-69.

[27] Ruppert LF, Finkelman RB, Boti E, Milosavljevic M, Tewalt S, Simon N, Dulong F. Origin and significance of high nickel and chromium concentrations in Pliocene lignite of the Kosovo Basin, Serbia. Int J Coal Geol, 1996, 29, 235-58.

[28] Dong H, Jiang XG, Lv GJ, Chi Y, Yan JH. Co-combustion of tannery sludge in a commercial circulating fluidized bed boiler. Waste Manage, 2015, 46, 227 - 33.

[29] Low F, Kimpton J, Wilson SA, Zhang LA. Chromium reaction mechanisms for speciation using synchrotron in-situ high-temperature X-ray diffraction. Env Sci Technol, 2015, 49, 8246 53. 
[30] Mao LQ, Deng N, Lui L, Cui H, Zhang WY. Inhibition of $\mathrm{Cr}(\mathrm{III})$ oxidation during thermal treatment of simulated tannery sludge: the role of phosphate. Chem Eng J, 2016, 294, 1-8.

[31] Kirk DW, Chan CCY, Marsh H. Chromium behavior during thermal treatment of MSW fly ash. J Hazard Mater, 2002, 90, 39-49.

[32] CRC Handbook of Chemistry and Physics. 73rd ed. Lide, D.R. Ed.; CRC Press: Boca Raton, FL, 1992, Section 4, pp 36-114.

[33] Volf, MB. Chemical approach to glass. Elsevier, Amsterdam, 1984.

[34] Yan L, Gupta RP, Wall TF. A mathematical model of ash formation during pulverized coal combustion. Fuel, 2002, 81, 337 - 344.

This chapter is based on an earlier published article:

Stam AF, Meij R, te Winkel H, van Eijk RJ, Huggins FE, Brem G. Chromium speciation in coal and biomass co-combustion products. Env Sci Technol, 2011, 45, 2450-6. 


\subsection{General Conclusion}

Co-firing of biomass has a significant impact on slagging characteristics. However, the impact is very dependent on the type of biomass; for instance, slagging reduces with co-firing wood and increases with co-firing a MBM-mix. Fouling increases with co-firing wood, MBM-mix and sheanut-mix. The increase in fouling is not linear with co-firing rate. Fouling steeply increases above $80 \%$ co-firing (on basis of mass input) wood or sheanut-mix, but gradually increases with the MBM-mix / coal ratio. More detailed conclusions on the mechanisms, modelling and experimental results are given below.

\subsection{Mechanisms}

\subsubsection{Superheater slagging in pf coal-fired boilers co-firing biomass}

In the investigated coal-firing and biomass co-firing cases, the bulk of the superheater deposits ("slagging") is formed by inertial impaction of molten particles. Thermophoresis and condensation (of alkalis) play a negligible role. Impacting molten particles consist either of $\mathrm{Fe}-\mathrm{O}-\mathrm{S}$ or slag. Deposition of molten Fe-O-S originates from minerals in coal ash and will decrease linearly with the biomass co-firing rate. The deposition rate depends both on the amount of the formed slag and the stickiness of the slag. The stickiness depends on viscosity which in its turn depends on the concentration of network formers and modifiers in the slag. With increased wood/coal ratio, the amount of formed slag decreases. The concentration of the network former $\mathrm{SiO}_{2}$ in the slag decreases, resulting in a lower viscosity and a higher stickiness of the slag. The combined effect is that the slagging propensity decreases with increased wood/coal ratio. With increased MBM$\mathrm{mix} / \mathrm{coal}$ ratio, the amount of formed slag increases. Also, the slag becomes stickier since the concentration of $\mathrm{SiO}_{2}$ in the slag decreases and the concentration of the network modifier $\mathrm{CaO}$ increases. Hence, the slagging propensity increases with increased MBM-mix/coal ratio.

\subsubsection{Fouling in pf coal-fired boilers co-firing biomass}

Fouling by molten alkali salts is related to the amount of gaseous alkalis that condense in the (relatively) colder convective parts of the boiler. The presence of these alkalis is determined by two main processes. The first process is the high-temperature process (above approximately 900 ${ }^{\circ} \mathrm{C}$ ) of association with aluminosilicates. Alkalis will associate with kaolinite, but mostly with slag. Dissolution of alkalis in the molten slag increases with the Si content in the slag and decreases with the $\mathrm{Ca}$ and $\mathrm{Mg}$ content in the slag. As more network-forming $\mathrm{Si}$ is present, more alkali (earth) elements can dissolve in the slag while alkali (earth) elements have to 'compete' with each other for a position in the network. Fouling increases with an increased biomass/coal ratio 
and decreases with the addition of coal fly ash as the $(\mathrm{CaO}+\mathrm{MgO})$ to $\mathrm{SiO}_{2}$ ratio in the slag increases, respectively decreases. Fouling is also related to the formation of molten alkali salts. The thermodynamic stability of these molten salts depends on the $\mathrm{S}$ to $\mathrm{Cl}$ ratio, the $\mathrm{K}$ to $\mathrm{Na}$ ratio, and temperature. Addition of ammonium sulphate will increase the $\mathrm{S}$ to $\mathrm{Cl}$ ratio which, in some cases, will cause the equilibrium to shift to a region where molten alkali salts are not stable, and thereby will decrease fouling.

\subsubsection{Ash deposition in biomass-fired fluidized bed boilers}

Firing of wood-based fuel blends in a BFB, results in superheater fouling deposits rich in $\mathrm{Ca}, \mathrm{K}$ and $\mathrm{S}$. The occurrence of alkalis in these deposits can be explained by gaseous alkalis that condense as small particles that are transported to the tube or deposit surface by thermophoresis, eddy diffusion and Brownian diffusion. Also, the alkalis can condense homogeneously on or in the deposit. Sintering occurs by sulphation of the Ca present in the deposit (in case of coarse particles deposited by inertial impaction) and by liquid flow of molten $\mathrm{K}-\mathrm{Na}-\mathrm{S}-\mathrm{Cl}$ salt given that the content of $\mathrm{Ca}$ (increasing the melting point) is low or $\mathrm{Ca}$ is chemically inert (e.g. as calcium silicate or slag).

\subsubsection{Chromium speciation with co-firing biomass in pf coal-fired boilers}

Organically bound $\mathrm{Cr}$ in coal or biomass may vaporize during combustion and with sufficient oxygen, $\mathrm{CrO}_{3}(\mathrm{~g})$ is formed in the flue gas. Upon cooling, $\mathrm{CrO}_{3}(\mathrm{~g})$ can be stabilized through a surface reaction at fly ash particles containing free lime $(\mathrm{CaO})$, as leachable $\mathrm{Cr}(\mathrm{VI})$. Hence, an increased wood/coal ratio may increase the percentage $\mathrm{Cr}(\mathrm{VI})$ of total $\mathrm{Cr}$ in fly ash since $\mathrm{Ca}$ in wood combustion is mainly present as free lime. Conversely, Ca in MBM is present as apatite and will not allow for such a reaction and percentages of $\mathrm{Cr}(\mathrm{VI})$ of total $\mathrm{Cr}$ may not increase. The largest part of the present $\mathrm{Cr}$ is bound in coal as illite or III-valent oxide and will be incorporated in the aluminosilicate melt, or will remain unchanged during combustion, respectively. In both cases, $\mathrm{Cr}$ in fly ash will occur as non-leachable $\mathrm{Cr}(\mathrm{III})$.

\subsection{Modelling}

\subsubsection{Pulverized fuel coal-fired boilers co-firing biomass}

In the models used in this thesis, the behaviour of inorganic elements during combustion is simulated using the approach of thermodynamic equilibrium. One of the limitations of an equilibrium approach is that the mode of occurrence of elements in the fuel is neglected. This is accounted for by introducing the so called 'availability of elements'. Traditionally, availability is based on chemical fractionation which has the drawback that $\mathrm{Si}, \mathrm{Al}$ and $\mathrm{Fe}$ are mostly considered non-reactive and no or only very little slag formation and alkali-ash interaction is taken into 
account. This approach is well suited for fluidized bed combustion but not for simulation of the combustion environment in a pulverized fuel boiler with a much higher maximum flue gas temperature. Therefore, a novel approach has been developed. Availability of elements in coal is based on mineralogical analyses of coal and coal fly ash. For biomass, chemical fractionation results are used and are complemented with the availability of elements in coal under the assumption that minerals in biomass are at least as available as the minerals in coal. Based on the equilibrium approach:

- a prediction model has been developed for superheater slagging propensity, i.e. sticking of inertially impacting molten particles of slag and molten Fe-O-S. Separate treatment of the FeO-S melt is new and has been neglected in previous models. Results (see 8.2.1) are in line with operating experience;

- insight in the high temperature process of interaction between $\mathrm{K}, \mathrm{Na}$ and fuel ash has been gained (see section 8.2.2);

- formation of molten alkali salt below $900{ }^{\circ} \mathrm{C}$ was investigated, showing that a molten salt can be formed with $\mathrm{S}: \mathrm{Cl} \leq 1.2$ if $\mathrm{K}: \mathrm{Na}>10$, with $\mathrm{S}: \mathrm{Cl} \leq 2.1$ if $2.4<\mathrm{K}: \mathrm{Na}<4.7$ and with $\mathrm{S}: \mathrm{Cl} \leq 3.5$ if $\mathrm{K}: \mathrm{Na}=1$. The $\mathrm{S}: \mathrm{Cl}$ ratio decreases with increasing biomass co-firing ratio. Addition of $1 \mathrm{~g} / \mathrm{MJ}$ ammonium sulphate can fully mitigate fouling with firing sheanut-mix and can lower fouling with firing wood up to a flue gas temperature of $700{ }^{\circ} \mathrm{C}$; however, it will increase fouling with wood above $700{ }^{\circ} \mathrm{C}$. Fouling with firing MBM-mix does not change with adding ammonium sulphate.

- $\quad$ Insight in the formation process of chromium speciation has been gained (see section 8.2.4)

\subsubsection{Fluidized bed boilers firing biomass}

A new modelling approach to predict the fouling propensity for firing biomass fuels in a fluidized bed boiler has been developed. The amount of molten salt as predicted by equilibrium at deposit temperature is used as a predictor for deposition propensity, rather than the traditional approach of using the amount of molten salt as a percentage of the total ash. The new approach proved to be better in comparison with practical data. An increasing fouling propensity is calculated for: 1) $100 \%$ wood chips, 2) $39 \%$ demolition wood, $39 \%$ wood cuttings, $6 \%$ compost overflow, $7 \%$ paper sludge, $9 \%$ roadside grass, 3) $6 \%$ wood chips, $68 \%$ wood cuttings, $9 \%$ compost overflow, $18 \%$ paper sludge and 4) $8 \%$ wood chips, 39\% demolition wood, $53 \%$ wood cuttings. The shares in the fuel blend are based on mass input (as received). The calculated results are in line with operational experience and air-cooled probe testing results. 


\subsection{Experimental}

\subsubsection{Air-cooled probe testing}

Air-cooled probe testing has been carried out in pulverized fuel (pf) boilers (see 8.2.1) and fluidized bed boilers (see 8.2.3) to get more insight in the deposit phases and deposition mechanisms. The results from the tests in the pf boilers confirmed:

- the assumption for the deposition propensity prediction model that the bulk of the deposits on the superheater probes are formed by inertial impaction of molten particles;

- that thermodynamic calculations are suitable to predict the molten phases (slag and Fe-O-S melt) responsible for the bulk of the formed deposits.

The results from the tests in a fluidized bed boiler confirmed that:

- the novel modelling approach (see 8.3.2) to predict the fouling propensity compares better with the practical data than the traditional modelling approach.

\subsubsection{Fly ash analyses}

Scanning Electron Microscopy of fly ash samples has shown that alkali-ash interactions occur at temperatures above approximately $900{ }^{\circ} \mathrm{C}$. Interactions occur especially between alkalis and slag and increase with a decrease of the $(\mathrm{CaO}+\mathrm{MgO})$ to $\mathrm{SiO}_{2}$ ratio (see 8.2.2).

The combination of XAFS, leaching and RE-factors gained insight in the formation process of chromium speciation (see 8.2.4). With sufficient oxygen, $\mathrm{CrO}_{3}(\mathrm{~g})$ is formed in the flue gas. Upon cooling, $\mathrm{CrO}_{3}(\mathrm{~g})$ can be stabilized through a surface reaction at fly ash particles containing free lime $(\mathrm{CaO})$, as leachable $\mathrm{Cr}(\mathrm{VI})$. 


\section{$9 \quad$ RECOMMENDATIONS}

\subsection{Modelling}

The prediction models for slagging and fouling presented in this thesis, can be readily used and require a fuel and ash analysis as is normally performed with the operation of solid fuel fired power plants. However, the standard analysis of coal does not involve the determination of the pyrite content and the determination if pyrite is present as liberated mineral or associated with other minerals. Therefore, a literature value is taken and is used as an assumption in the slagging model. Incorporation of a pyrite analysis in the standard fuel analysis would therefore be recommended and, in addition, a larger data set regarding included and excluded pyrite will indicate the bandwidth of this data. Fuel characterization data is taken from literature. It is advised to generate a broader set of coal characterization by analysis of minerals in coal and fly ash as part of a full scale combustion trial. Other than the data set from [1], literature focusses on the (quantitative) mineral composition of either coal or coal fly ash, but not both at the same time, so the change of minerals due to combustion cannot be quantified. Furthermore, a larger database of chemical fractionation data of biomass, especially those which will be used in The Netherlands such as wood, is worthwhile, to obtain a bandwidth of fuel characterization data.

To increase the practical use of the slagging and fouling prediction models, it is recommended to produce a set of modelling results based on a variety of coal blends and range of biomass fuels and compositions. An interpolation of the results can be made for practical application.

The slagging predication model presented in this thesis can be incorporated in a CFD boiler model and allows for simulation of local effects. This can be interesting, for example, with high co-firing percentages. Since the combustion behaviour of biomass is different compared to coal, the local conditions in the boiler, such as flow, oxygen concentration and temperature can change. Therewith, the local slagging behaviour may also change. It is recommended that, if high biomass co-firing rates or even full conversion from coal to biomass is considered, a CFD boiler model is developed with incorporation of a slagging prediction model. Such a model has been developed for instance for the Maasvlakte 1 and 2 boilers, see [2]. A more detailed (in terms of heat exchangers) and optimized (e.g. meshing) model has been developed by [3], and some results are shown in Figure 9.1. 

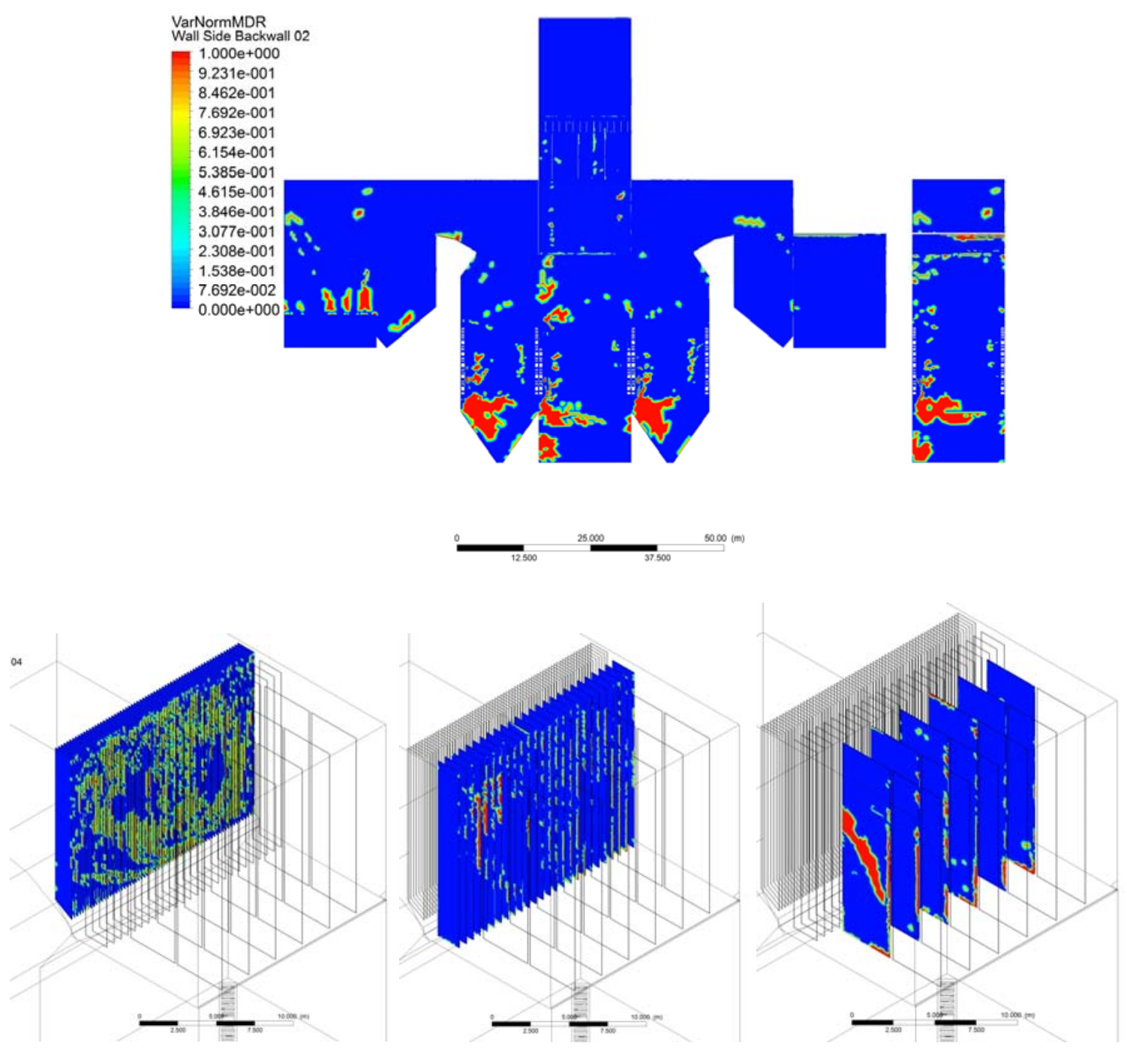

Figure 9.1 Particle deposition probability of boiler walls (fold-out, top), reheater front (bottom left), final superheater (bottom, middle) and platen superheater 2 (bottom, right). Fuel: coal blend. Source: [3].

\section{$9.2 \quad$ Measurements}

In chapter 5, model predictions show that, without addition of coal fly ash or ammonium sulphate, the formation of molten salts rapidly increases when the biomass is co-firing percentage is above a certain level, where the level depends on the type of biomass. The molten salts are thermodynamically stable above $500{ }^{\circ} \mathrm{C}$, i.e. fouling problems could occur in the economizer region. It is recommended to validate the modelling results with air-cooled probes in a boiler that has been converted from coal to biomass by exposing the probes in the economizer area. 
In chapter 6, it was concluded that "Whether $\mathrm{KCl}$ has deposited that later sulphatized, or that $\mathrm{K}_{2} \mathrm{SO}_{4}$ has deposited, or a combination of the two, cannot be established." To establish this, it is recommended to perform air-cooled probe tests for very short time periods (in the order of 1 hour). This will expose if the initial deposits are chlorides or sulphates.

\subsection{Monitoring and validation}

Uniper operated two pulverized coal-fired boilers co-firing biomass, units 1 and 2 at Maasvlakte, the Netherlands. Troublesome superheater deposits occurred that, if weren't removed, could lead to a quick build up and clogging of the superheaters and horizontal pass leading to standstill. To monitor deposit build up, the superheaters were visually checked by Uniper personnel using a welding shield as protection and filter. The results were laid down graphically and the severity of slagging per bundle was noted on a scale of $0-4$. The sum of these numbers over 48 bundles (as part of the primary, secondary and tertiary superheater, and the reheater) yielded the slagging number, and a weekly average of this slagging number is shown in Figure 9.2.

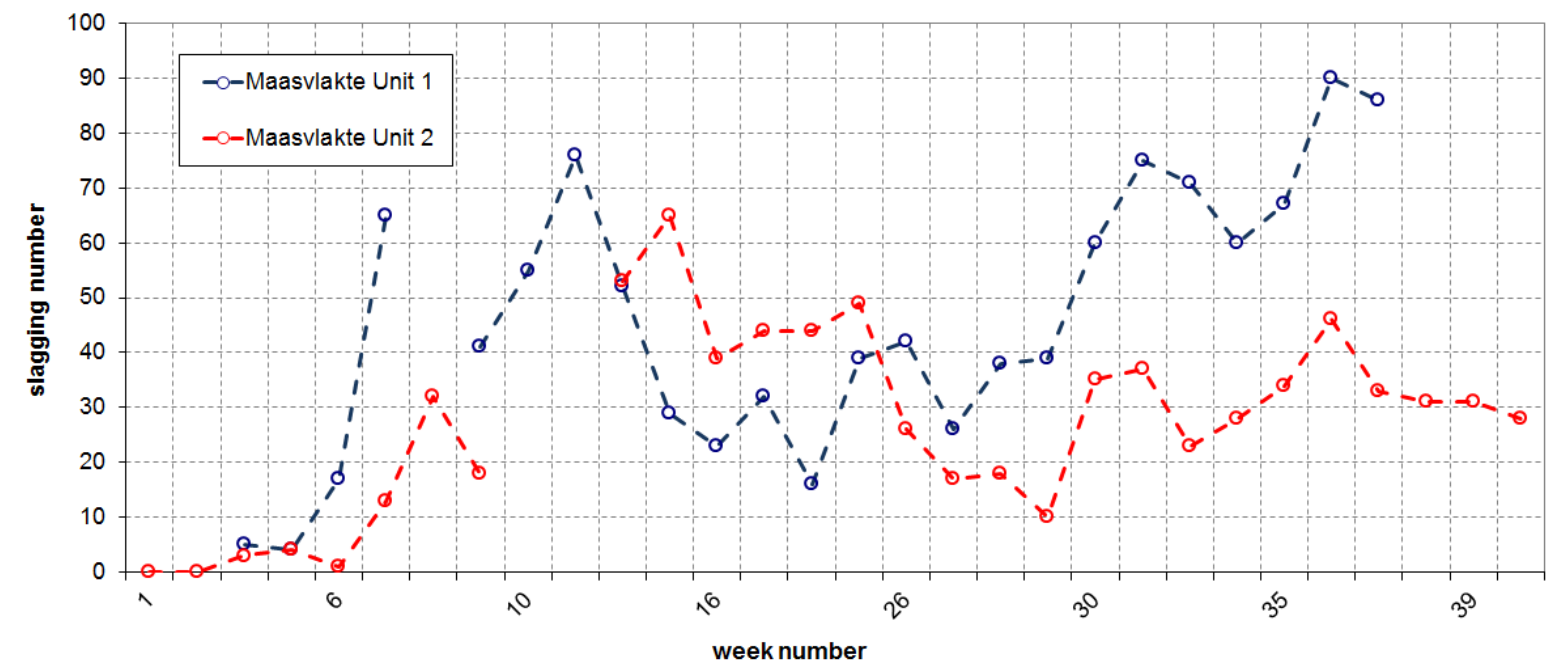

Figure 9.2 Slagging number derived from visual observations from superheaters and reheaters in coal-fired power plant Maasvlakte, units 1 and 2.

However, visual monitoring proved to be labour-intensive and also insufficient: within the inspection interval (varying from 2 days to 1 month), deposits could build up to the point that they weren't removable anymore. With intelligent soot blowing systems, build-up of deposits is monitored using operational data (such as steam temperatures). Following this concept, an attempt was made to generate a good predictor for the slagging number by correlating the slagging number with a set of operational data using linear regression. A fair correlation was 
achieved with a training set $\left(r^{2}=0.62\right)$, but using a similar data set from a later (but shorter) time frame for validation resulted in a bad correlation $\left(r^{2}=0.08\right)$. The most probable reason of the bad correlation is that the data of the training set and validation set are quite different in terms of slagging number and the distribution of deposition over the different bundles.

A result of the visual monitoring was that soot blowing (which was performed according to a timely schedule) was not always effective and sometimes not necessary. Therefore, a camera was designed and built for on-line visual monitoring of the superheaters for rapid deposit build-up and the efficiency or necessity of soot blowing. The camera was installed in an available inspection hatch and was therefore positioned under an angle of the horizontal and vertical plane, see Figure 9.3. The camera lies back from the opening in the boiler wall and is provided with an air cooling and purging system. Use is made of colour filters (the local gas temperature is in excess of $1,000{ }^{\circ} \mathrm{C}$ ) and the area of the superheaters that can be monitored is several meters into the boiler, see Figure 9.3. Monitoring showed to be successful: the camera images were projected on a screen at the watch and mitigating actions could be taken immediately. No clogging problems were reported since. An air-cooled camera for monitoring deposit build-up is therefore recommended as a cost-effective solution for plants with slagging problems.
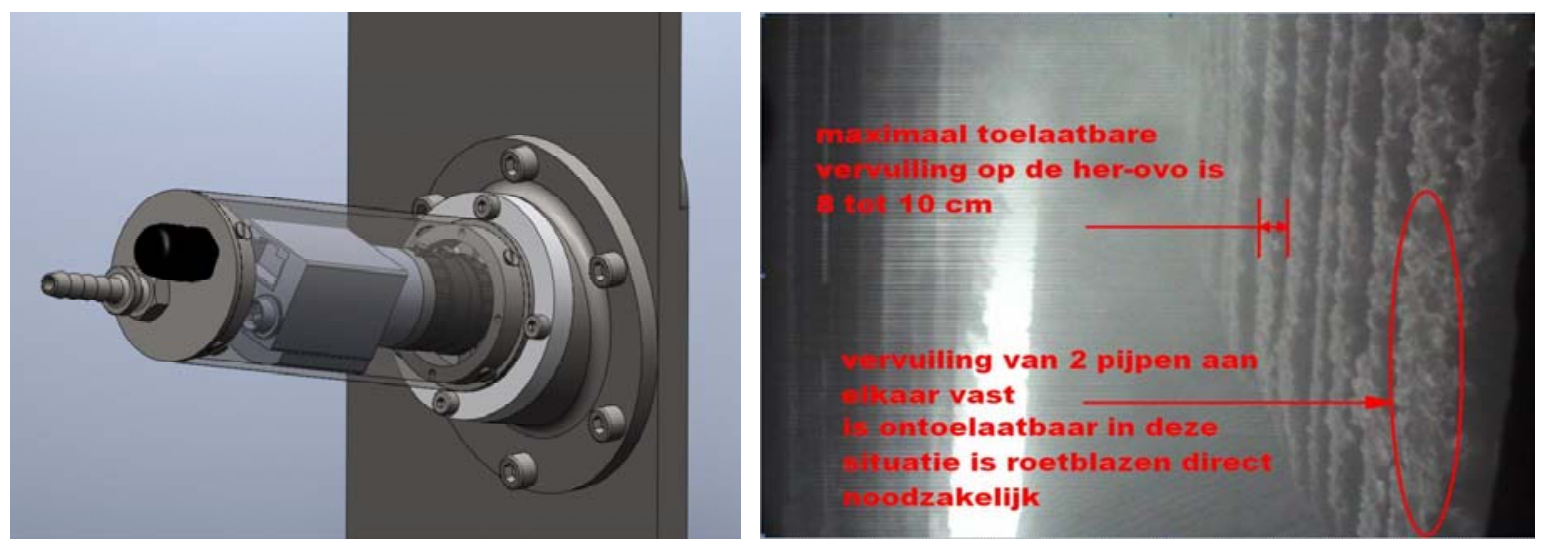

Figure 9.3 Left: drawing of air-cooled camera for monitoring deposit build-up at superheaters and reheaters. Right: image generated using air-cooled camera.

A recommendation for further research is to quantify the camera images using image correlation. Together with fuel composition data, this will provide a large data set for validation of the prediction models presented in this thesis. The validation set can possibly be made more detailed by further pursuing regression analysis between operational data and the slagging number with a larger and more comparable training and validation data set. In addition, multiple cameras could be used in different positions, and different predictors of deposition in different boiler areas could be derived. 


\section{$9.4 \quad$ Additives}

The addition of coal fly ash and ammonium sulphate has been discussed in Chapter 5 . The modelling results show that these additives can be used to reduce or overcome fouling in a number of cases. Full scale tests with air-cooled probes are advised to validate the modelling results and to gain insight in the dosing optimal strategy due to effects of mixing of the additive and reaction rates.

Whether coal fly ash and ammonium sulphate can actually be used as additives depends on the economic viability and the limitations set in the permits for the plant. Therefore, the investigation of other additives is advised. For example, tests have been performed with addition of paper sludge ash to a waste incinerating boiler. The ash consists mainly of calcium oxide, calcium carbonate and (meta-)kaolinite, reflecting the composition of paper fillers. About $40 \mathrm{~kg} / \mathrm{h}$ of ash was added to a waste incinerating boiler during a 21 days trial. Deposits were collected with aircooled probes in the superheater region, during and before the trial. Microscopic investigation of the deposits showed a strong decrease in the formation of calcium sulphate in the deposit, see Figure 9.4. This is explained by thermodynamic equilibrium calculations showing absorption of gaseous sulphur by calcium oxide in the paper sludge ash that is ultimately removed from the boiler as fly ash. Gaseous sulphur otherwise sulphatizes the deposits, leading to hard, sintered deposits that are difficult to remove. Further research of addition of paper sludge ash to biomass (co-)firing plants is considered worthwhile.
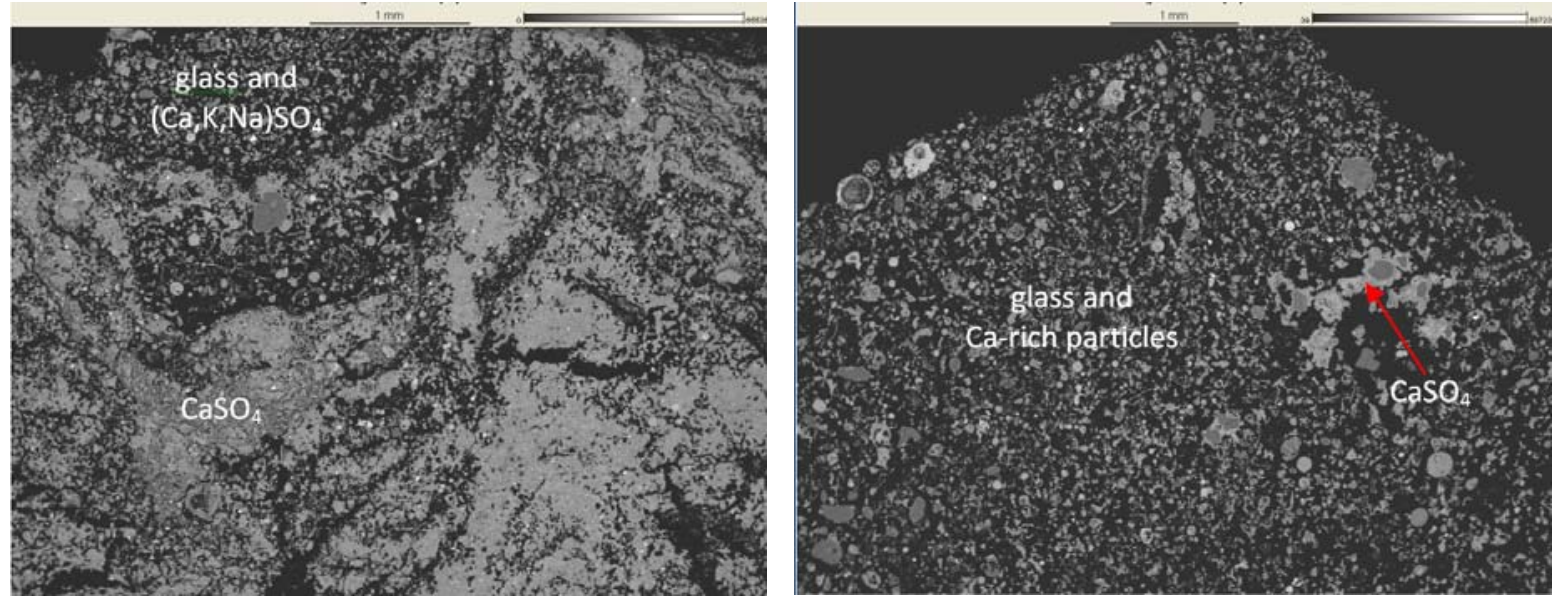

Figure 9.4 Backscatter plots of superheater probe deposit (top and bottom) without additive (left) and with additive (right). 


\section{$9.5 \quad$ Trace elements}

The $\mathrm{Cr}$ speciation measurements for wood firing have been performed at ashes from a fluidized bed power plant. Currently, a number of coal-fired power plants have been converted from coal to wood. As stated in Chapter 5, the firing temperature is of importance in the fate of elements during combustion. Since the firing temperature in a pulverized fuel boiler is higher than in a fluidized bed boiler, it is recommended to investigate ashes from pulverized fuel boilers firing only wood and to check if any difference in $\mathrm{Cr}$ speciation can be observed.

Aside from chromium, also the toxicity of Se and As depends on the speciation of the elements. The oxidation state of these elements is important for solubility and also toxicity: As(III) is more toxic than $\mathrm{As}(\mathrm{V})$, noticeably 50 times [4], and, in general, Se(IV) is more toxic than $\mathrm{Se}(\mathrm{VI})$ [5]. In literature about XAFS-investigations on As in coal combustion ash ([6], [7], [8], [9] and [10]), the only reported oxidation state of $A s$ is $A s(V)$. In investigations by [10], [11], [12] and [13], Se was found to be predominantly $\mathrm{Se}(\mathrm{IV})$, and some cases, minor amounts of $\mathrm{Se}(0)$ were found. Thermodynamic calculations by [14] did not show a change in As and Se speciation for co-firing $40 \%$ wood (on basis of thermal heat input) compared to firing only coal. In addition, yet unpublished XAFS results on fly ash resulting from co-firing up to $18 \%$ MBM-mix, $21 \%$ sheanutmix or $38 \%$ wood with coal did not show any detectable oxidation state of arsenic and selenium than $\mathrm{As}(\mathrm{V})$ and $\mathrm{Se}(\mathrm{IV})$. However, in Chapter 5 it is shown that with thermodynamic simulation for co-firing wood, the speciation of $\mathrm{K}$ and $\mathrm{Na}$ dramatically changes with co-firing percentages well above $80 \%$. Similar results were found (which are yet unpublished) for $\mathrm{Pb}$ and $\mathrm{Zn}$. It is therefore recommended to perform thermodynamic calculations for co-firing $0-100 \%$ wood as well as MBM with coal for a range of elements, especially for elements As and Se. In addition, XAFS measurements on ashes for high co-firing percentages of wood as well as MBM should be performed.

\section{References}

[1] Vassilev SV, Menendez R, Alvarez D, Diaz-Somoanob M, Martinez-Tarazonab MR. Phasemineral and chemical composition of coal fly ashes as a basis for their multicomponent utilization.

1. Characterization of feed coals and fly ashes. Fuel, 2003, 82, 1793-811.

[2] Taha TJ, Stam AF, Stam K, Brem G. CFD modeling of ash deposition for co-combustion of MBM with coal in a tangentially fired utility boiler. Fuel Proc Technol, 2013, 114, 126-34.

[3] Schmitt M, Stam AF. CFD Boiler Model Maasvlakte Unit 1/2, KEMA, 2013.

[4] Hodgson E, Mailman RB, Chambers JE. Dictionary of Toxicology; Macmillan: London, 1988. 
[5] Cobo Fernandez MG, Palacios MA, Camara C. Flowinjection and continuous-flow systems for the determination of $\mathrm{Se}(\mathrm{IV})$ and $\mathrm{Se}(\mathrm{VI})$ by hydride generation atomic absorption spectrometry with on-line prereduction of Se(VI) to Se(IV). Anal Chim Acta, 1993, 283, 386 - 92.

[6] Huffman GP, Huggins FE, Shah N, Zhao J. Speciation of arsenic and chromium in coal and combustion ash by XAFS spectroscopy. Fuel Process Technol, 1994, 39, 47-62.

[ 7] Shoji T, Huggins FE, Huffman GP. XAFS spectroscopy analysis of selected elements in fine particulate matter derived from coal combustion. Energy Fuels, 2002, 16, 325-9.

[8] Galbreath KC, Zygarlicke CJ. Formation and chemical speciation of arsenic-, chromium-, and nickel-bearing coal combustion PM2.5. Fuel Process Technol, 2004, 85, 701-26.

[9] Zielinsk, RA, Foster AL, Meeker GP, Brownfield IK. Mode of occurrence of arsenic in feed coal and its derivative fly ash, Black Warrior Basin, Alabama. Fuel, 2007, 86, 560-72.

[10] Huggins FE, Senior CL, Chu P, Ladwig K, Huffman GP. Selenium and arsenic speciation in fly ash from full-scale coal-burning utility plants. Environ Sci Technol, 2007, 41, 3284-9.

[11] Luo Y, Giammar DE, Huhmann BL, Catalano JG. Speciation of selenium, arsenic and zinc in class C fly ash. Energy Fuels, 2011, 25, 2980-7.

[12] Shah P, Strezov V, Stevanov V, Nelson PF. Speciation of arsenic and selenium in coal combustion products. Energy Fuels, 2007, 21, 506-12.

[13] Shah P, Strezov V, Prince K, Nelson F. Speciation of As, $\mathrm{Cr}$, Se and $\mathrm{Hg}$ under coal fired power station conditions. Fuel, 2008, 87, 1859-69.

[14] Stam AF, Meij R, Te Winkel BH, Cieplik M. Predictions of the speciation of elements in coal ash with thermodynamic equilibrium calculations for advanced techniques in pf-coal-fired power plants co-firing biomass, 32nd International Conference on Coal Utilization \& Fuel systems, Clearwater, USA, Jun 15, 2007. 


\section{APPENDICES}

\section{Appendix to chapter 4}

Appendix 4.A Sketch of boilers with location of probes

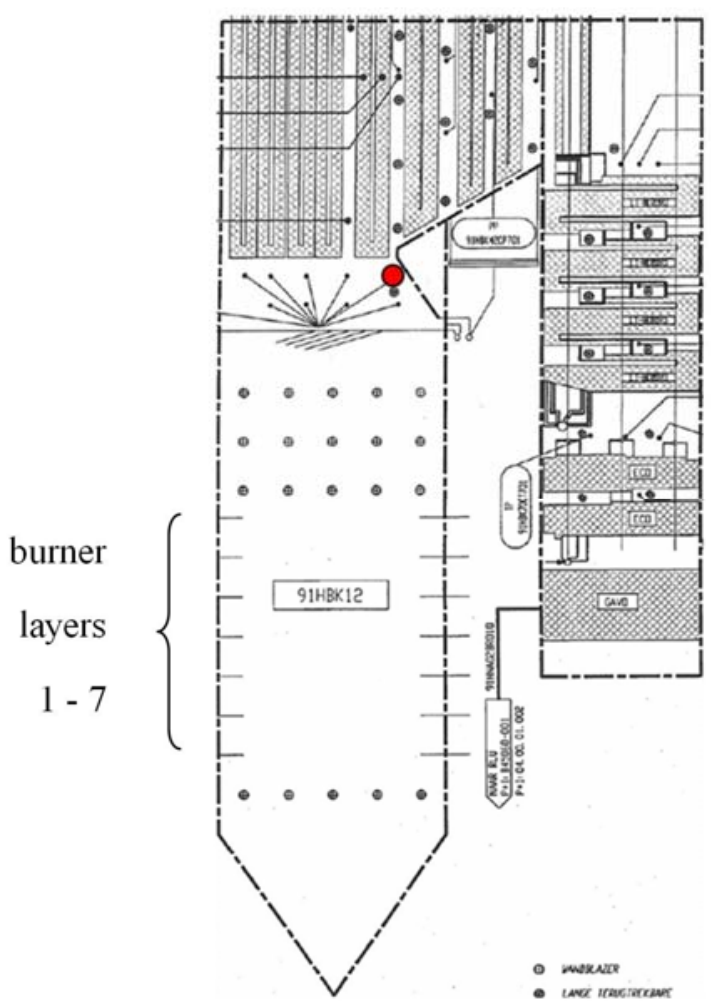

Figure 4.A.1 Location of exposed probe at Amer power station unit 9 (red circle). 


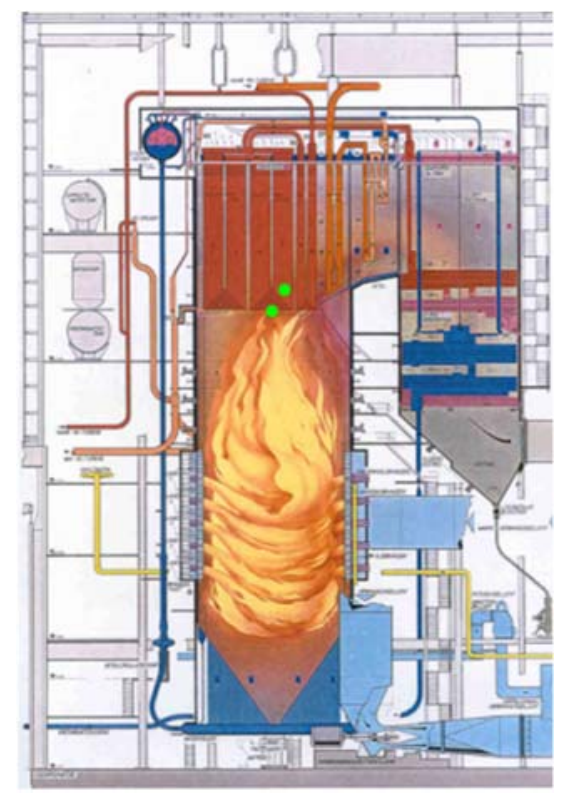

Figure 4.A.2 Location of exposed probe at Maasvlakte power station unit 1 (green circles). 
Appendix 4.B Selected compounds in equilibrium calculations

Table 4.B.1 Selected compounds in equilibrium calculations

gas $\quad \mathrm{H}, \mathrm{H}_{2}, \mathrm{C}, \mathrm{CH}_{4}, \mathrm{C}_{2} \mathrm{H}_{2}, \mathrm{C}_{2} \mathrm{H}_{4}, \mathrm{~N}_{2}, \mathrm{NH}_{2}, \mathrm{NH}_{3}, \mathrm{CN}, \mathrm{HCN}, \mathrm{O}, \mathrm{O}_{2}, \mathrm{O}_{3}, \mathrm{OH}, \mathrm{H}_{2} \mathrm{O}, \mathrm{CO}, \mathrm{CO}_{2}$, $\mathrm{HCO}, \mathrm{H}_{2} \mathrm{CO}, \mathrm{CH}_{3} \mathrm{OH}, \mathrm{CH}_{2} \mathrm{CO}, \mathrm{HCOOH}, \mathrm{NO}, \mathrm{N}_{2} \mathrm{O}, \mathrm{NO}_{2}, \mathrm{NO}_{3}, \mathrm{~N}_{2} \mathrm{O}_{3}, \mathrm{HNO}, \mathrm{Na}$, $\mathrm{NaCN}, \mathrm{NaO}, \mathrm{NaOH}, \mathrm{Mg}, \mathrm{MgO}, \mathrm{MgOH}, \mathrm{Mg}(\mathrm{OH})_{2}, \mathrm{Al}, \mathrm{AlO}, \mathrm{AlO}_{2}, \mathrm{AlOH}, \mathrm{OAIOH}, \mathrm{SiO}$, $\mathrm{P}, \mathrm{P}_{2}, \mathrm{PH}_{3}, \mathrm{PO}, \mathrm{PO}_{2},\left(\mathrm{P}_{2} \mathrm{O}_{3}\right)_{2}, \mathrm{~S}, \mathrm{~S}_{2}, \mathrm{~S}_{3}, \mathrm{~S}_{4}, \mathrm{~S}_{5}, \mathrm{HS}, \mathrm{H}_{2} \mathrm{~S}, \mathrm{H}_{2} \mathrm{~S}_{2}, \mathrm{CS}, \mathrm{CS}_{2}, \mathrm{CH}_{3} \mathrm{SH}$, HCNS, SO, $\mathrm{SO}_{2}, \mathrm{COS}, \mathrm{Na}_{2} \mathrm{SO}_{4}, \mathrm{MgS}, \mathrm{Cl}, \mathrm{Cl}_{2}, \mathrm{HCl}, \mathrm{NaCl},(\mathrm{NaCl})_{2}, \mathrm{MgCl}, \mathrm{MgCl}_{2}$, $\mathrm{AlCl}, \mathrm{AlCl}_{2}, \mathrm{AlCl}_{3}, \mathrm{OAICl}, \mathrm{PCl}, \mathrm{Ar}, \mathrm{K}, \mathrm{K}, \mathrm{KH}, \mathrm{KCN}, \mathrm{KO}, \mathrm{KOH},(\mathrm{KOH})_{2}, \mathrm{~K}_{2} \mathrm{SO}_{4}, \mathrm{KCl}$, $\mathrm{Ca}, \mathrm{CaO}, \mathrm{CaOH}, \mathrm{Ca}(\mathrm{OH})_{2}, \mathrm{CaS}, \mathrm{CaCl}, \mathrm{CaCl}_{2}, \mathrm{TiO}, \mathrm{OTiCl}, \mathrm{TiOCl}_{2}, \mathrm{Fe}, \mathrm{FeO}$, $\mathrm{Fe}(\mathrm{OH})_{2}, \mathrm{FeS}, \mathrm{FeCl}, \mathrm{FeCl}_{2}, \mathrm{FeCl}_{3},\left(\mathrm{FeCl}_{3}\right)_{2}, \mathrm{NaFeCl}_{4}$

\begin{tabular}{|c|c|}
\hline solution & E, FeS-liq \\
\hline solid & 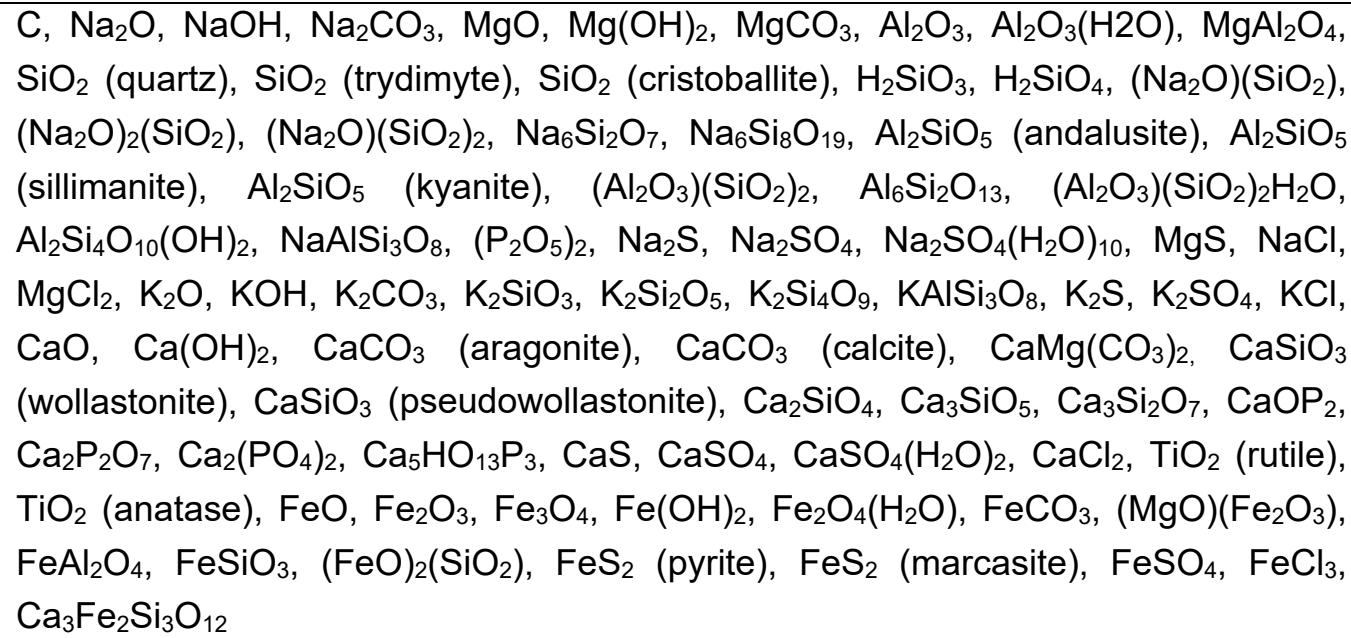 \\
\hline
\end{tabular}


Appendix 4.C Mineral change based on comparisons between five pairs of high temperature ash of coal and resulting fly ash.

The available mass of an element in a formed mineral is calculated by multiplying $1 \mathrm{~kg}$ fuel ash, the concentration of the mineral in the fuel ash (HTA, High Temperature Ash), the (stoichiometric) concentration of the element in a mineral and the change of the mineral (based on concentration in HTA and FA (Fly Ash)), see Table 4.C.1. That is done for all the minerals that are formed in which the element is present. For example, Fe is present in the formed minerals melilite and magnetite. These masses are summed and the sum is divided by the total mass of the element in $1 \mathrm{~kg}$ of fuel ash. This yields the availability of an element based on formed minerals. The same can be done for transformed (disappeared) minerals (for example, for Fe these are hematite, siderite and ankerite), yielding the availability of an element based on transformed minerals. The maximum value of these two availabilities (based on formation and transformation) is then used as 'the availability' of an element. As a last step, the calculated availabilities were averaged on the five different fuel ash and fly ash combinations in the dataset of Vassilev et al. [10]. 
Table 4.C.1 Mineral change based on comparisons between five pairs of high temperature ash of coal and resulting fly ash, source: [10].

\begin{tabular}{|c|c|c|c|c|c|c|c|c|c|c|c|c|c|c|c|c|}
\hline \multirow[t]{3}{*}{ mineral } & \multirow[t]{3}{*}{ formula } & \multicolumn{3}{|c|}{ Coal1 } & \multicolumn{3}{|l|}{ Coal2 } & \multicolumn{3}{|l|}{ Coal3 } & \multicolumn{3}{|l|}{ Coal4 } & \multicolumn{3}{|c|}{ Coal5 } \\
\hline & & HTA & $\mathrm{F}$ & $\Delta(\%)$ & HTA & $\mathrm{FA}$ & $\Delta(\%)$ & HTA & $\mathrm{F}$ & $\Delta(\%)$ & HTA & $\mathrm{F}$ & $\Delta(\%)$ & HTA & $\mathrm{F}$ & $\Delta(\%)$ \\
\hline & & & A & & & & & & A & & & A & & & A & \\
\hline \multirow[t]{2}{*}{ Amorphous } & - & 26 & 6 & & 23 & 69 & & 23 & 6 & & 17 & 7 & & 17 & 6 & \\
\hline & & & 4 & & & & & & 8 & & & 8 & & & 7 & \\
\hline \multirow[t]{2}{*}{ Quartz } & $\mathrm{SiO}_{2}$ & 28 & 1 & -62 & 32 & 11 & -65 & 18 & 1 & -38 & 38 & 5 & -86 & 32 & 9 & -72 \\
\hline & & & 1 & & & & & & 1 & & & & & & & \\
\hline \multirow[t]{2}{*}{ Cristobalite } & $\mathrm{SiO}_{2}$ & 0 & 1 & +10 & 0 & 1 & +100 & 0 & 1 & +100 & 0 & 1 & +100 & 0 & 1 & +100 \\
\hline & & & & 0 & & & & & & & & & & & & \\
\hline Kaolinite & $\mathrm{Al}_{2} \mathrm{Si}_{2} \mathrm{O}_{5}(\mathrm{OH})_{4}$ & 8 & 2 & -73 & 9 & 2 & -74 & 15 & 1 & -93 & 10 & 1 & -87 & 9 & 1 & -88 \\
\hline $\begin{array}{l}\text { Illite }+ \\
\text { muscovite }\end{array}$ & $\mathrm{KAl}_{2}\left(\mathrm{Si}_{3}, \mathrm{Al}\right) \mathrm{O}_{10}(\mathrm{OH})_{2}$ & 6 & 0 & -100 & 10 & 0 & -100 & 6 & 0 & -100 & 9 & 0 & -100 & 7 & 0 & -100 \\
\hline \multirow[t]{2}{*}{ Mullite } & $\mathrm{Al}_{4.5} \mathrm{Si}_{1.5} \mathrm{O}_{9.75}$ & 0 & 1 & +10 & 0 & 9 & +100 & 0 & 1 & +100 & 0 & 8 & +100 & 0 & 1 & +100 \\
\hline & & & 3 & 0 & & & & & 2 & & & & & & 5 & \\
\hline $\begin{array}{l}\text { Montmorillo } \\
\text { nite }\end{array}$ & $\begin{array}{l}\mathrm{Na}_{0.2} \mathrm{Ca}_{0.1} \mathrm{Al}_{2} \mathrm{Si}_{4} \mathrm{O}_{10}(\mathrm{OH})_{2}( \\
\left.\mathrm{H}_{2} \mathrm{O}\right)_{10}\end{array}$ & 1 & 0 & -100 & 2 & 0 & -100 & 1 & 0 & -100 & 1 & 0 & -100 & 1 & 0 & -100 \\
\hline Plagioclase & $(\mathrm{Na}, \mathrm{Ca}) \mathrm{Al}(\mathrm{Al}, \mathrm{Si}) \mathrm{Si}_{2} \mathrm{O}_{8}$ & 3 & 1 & -63 & 3 & 1 & -61 & 8 & 1 & -86 & 2 & 1 & -36 & 3 & 1 & -63 \\
\hline K-feldspar & $\mathrm{KAISi}_{3} \mathrm{O}_{8}$ & 2 & 1 & -45 & 2 & 1 & -42 & 2 & 1 & -44 & 2 & 1 & -36 & 1 & 1 & 0 \\
\hline \multirow[t]{2}{*}{ Wollastonite } & $\mathrm{CaSiO}_{3}$ & 0 & 1 & +10 & 0 & 0 & - & 0 & 0 & - & 0 & 0 & - & 0 & 0 & - \\
\hline & & & & 0 & & & & & & & & & & & & \\
\hline \multirow[t]{2}{*}{ Melilite } & $\mathrm{Ca}_{1.5} \mathrm{Na}_{0.5} \mathrm{Al}_{1.1} \mathrm{Mg}_{0.3} \mathrm{Fe}_{0.1} \mathrm{Si}$ & 0 & 1 & +10 & 0 & 1 & +100 & 0 & 1 & +100 & 0 & 0 & - & 0 & 1 & +100 \\
\hline & ${ }_{1.5} \mathrm{O}_{7}$ & & & 0 & & & & & & & & & & & & \\
\hline \multirow[t]{2}{*}{ Magnetite } & $\mathrm{Fe}_{3} \mathrm{O}_{4}$ & 0 & 1 & +10 & 0 & 1 & +100 & 0 & 1 & +100 & 0 & 1 & +100 & 0 & 1 & +100 \\
\hline & & & & 0 & & & & & & & & & & & & \\
\hline Lime & $\mathrm{CaO}$ & 1 & 0 & -100 & 1 & 0 & -100 & 1 & 0 & -100 & 2 & 0 & -100 & 1 & 0 & -100 \\
\hline Periclase & $\mathrm{MgO}$ & 1 & 0 & -100 & 1 & 0 & -100 & 1 & 0 & -100 & 1 & 0 & -100 & 1 & 0 & -100 \\
\hline Hematite & $\mathrm{Fe}_{2} \mathrm{O}_{3}$ & 6 & 3 & -45 & 6 & 2 & -61 & 8 & 1 & -86 & 7 & 1 & -82 & 5 & 2 & -56 \\
\hline Corundum & $\mathrm{Al}_{2} \mathrm{O}_{3}$ & 2 & 1 & -45 & 0 & 0 & -100 & 1 & 0 & -100 & 0 & 0 & - & 0 & 0 & - \\
\hline Anhydrite & $\mathrm{CaSO}_{4}$ & 3 & 1 & -63 & 4 & 1 & -71 & 8 & 1 & -86 & 4 & 1 & -68 & 4 & 1 & -72 \\
\hline Siderite & $\mathrm{FeCO}_{3}$ & 1 & 0 & -100 & 1 & 0 & -100 & 1 & 0 & -100 & 1 & 0 & -100 & 1 & 0 & -100 \\
\hline Calcite & $\mathrm{CaCO}_{3}$ & 11 & 0 & -100 & 3 & 0 & -100 & 5 & 0 & -100 & 3 & 0 & -100 & 17 & 0 & -100 \\
\hline Dolomite & $(\mathrm{Ca}, \mathrm{Mg}) \mathrm{CO}_{3}$ & 1 & 0 & -100 & 2 & 0 & -100 & 2 & 0 & -100 & 2 & 0 & -100 & 1 & 0 & -100 \\
\hline Ankerite & $\mathrm{Ca}(\mathrm{Fe}, \mathrm{Mg}) \mathrm{CO}_{3}$ & 1 & 0 & -100 & 2 & 0 & -100 & 1 & 0 & -100 & 1 & 0 & -100 & 1 & 0 & -100 \\
\hline
\end{tabular}


Appendix D Slag particles rich $\mathrm{Ca}$ and $\mathrm{P}$

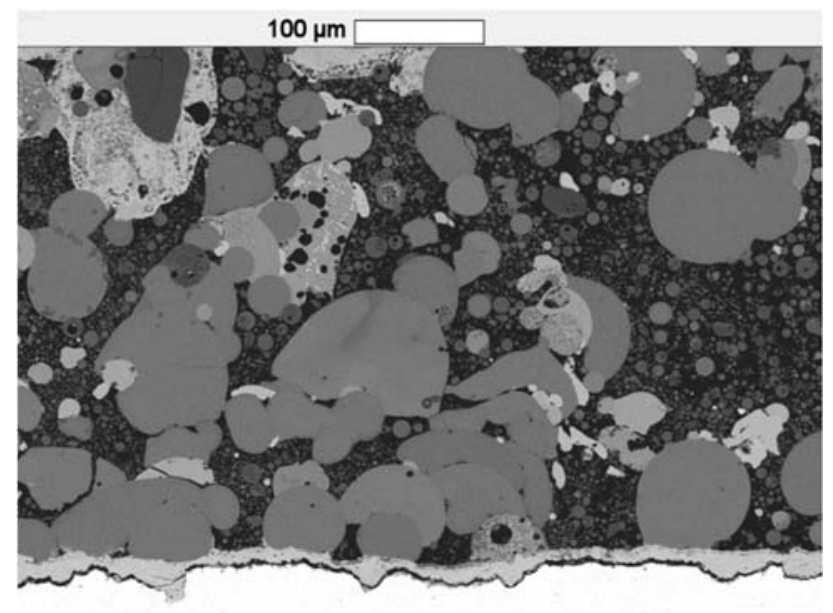

Figure 4.D.1 Deposit co-firing coal with MBM and biomass pellets, ('test MV1-1'), back scatter image. The composition of slag particles rich in $\mathrm{Ca}$ and $\mathrm{P}$ (indicated with "*") has been analysed.

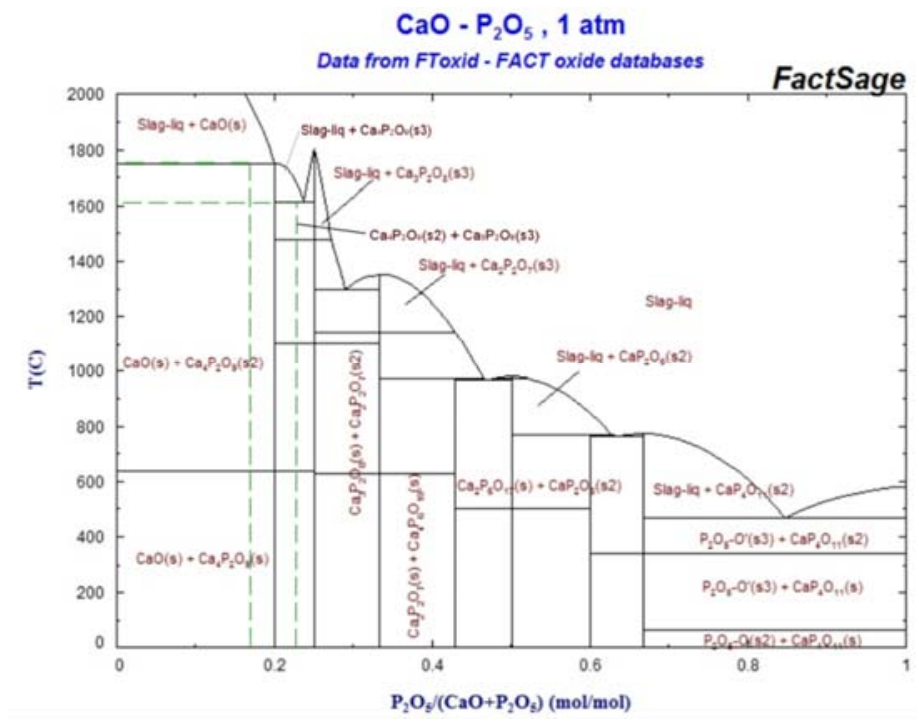

Figure 4.D.2 Phase diagram of system $\mathrm{CaO}-\mathrm{P}_{2} \mathrm{O}_{5}$ (source: [32]) indicating $\mathrm{P}_{2} \mathrm{O}_{5} /\left(\mathrm{P}_{2} \mathrm{O}_{5}+\mathrm{CaO}\right.$ ) minimum and maximum ratios (green lines) of analysed $\mathrm{Ca}$ and $\mathrm{P}$-rich slag particles (see Figure 4.D.1). 
Appendix 4.E Microscopic results

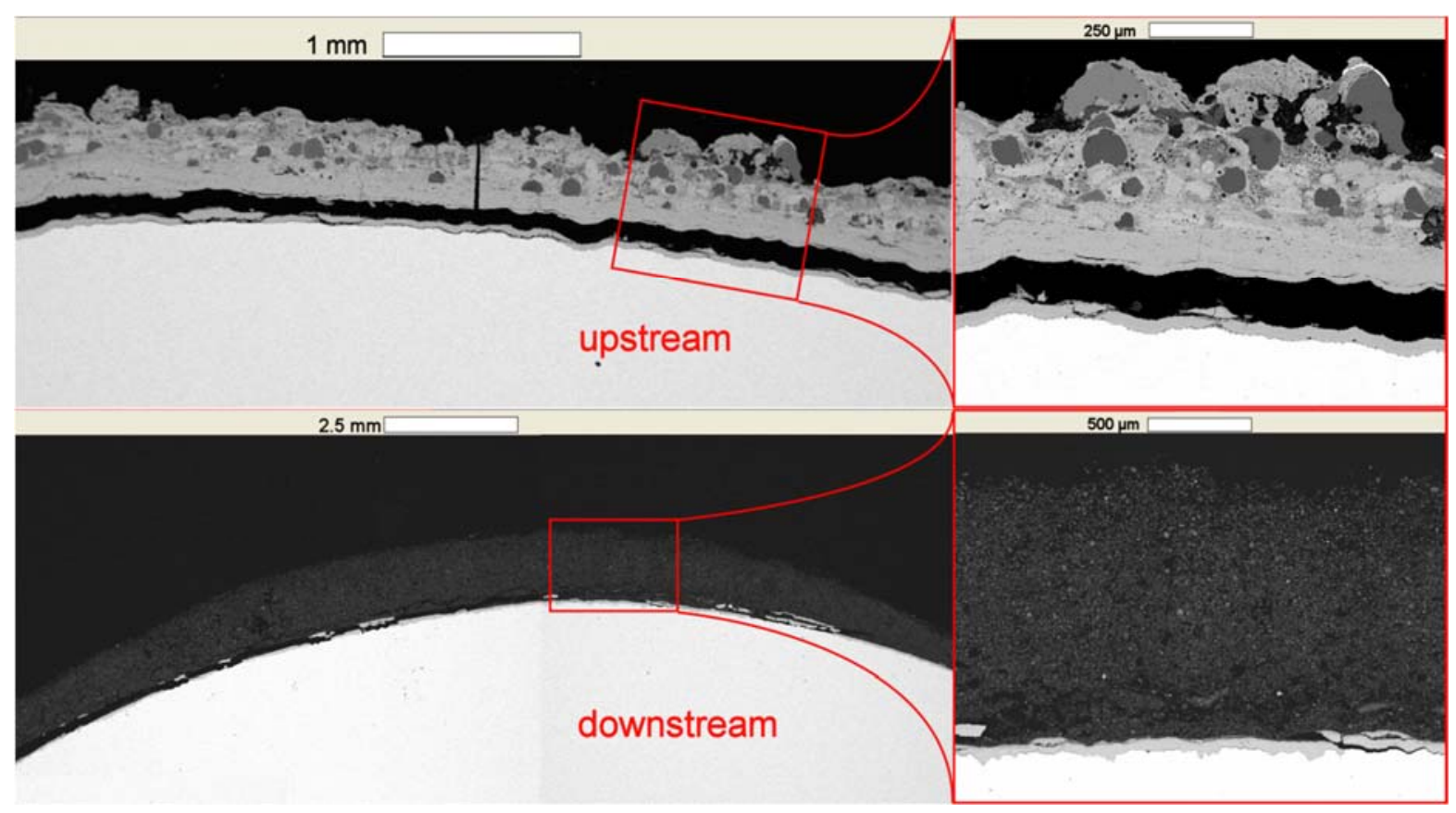

Figure 4.E.1 Back scatter images of upstream (top) and downstream (bottom) deposits, coal firing (1 week test). Top: composition Fe (20\%), Si (5\%), Al (3\%), Ca (3\%), Mg (1\%), S (1\%). Bottom: Al 7\%; Si 10\%; Ca 1\%; Fe 1\%. Right: flue gas direction. 


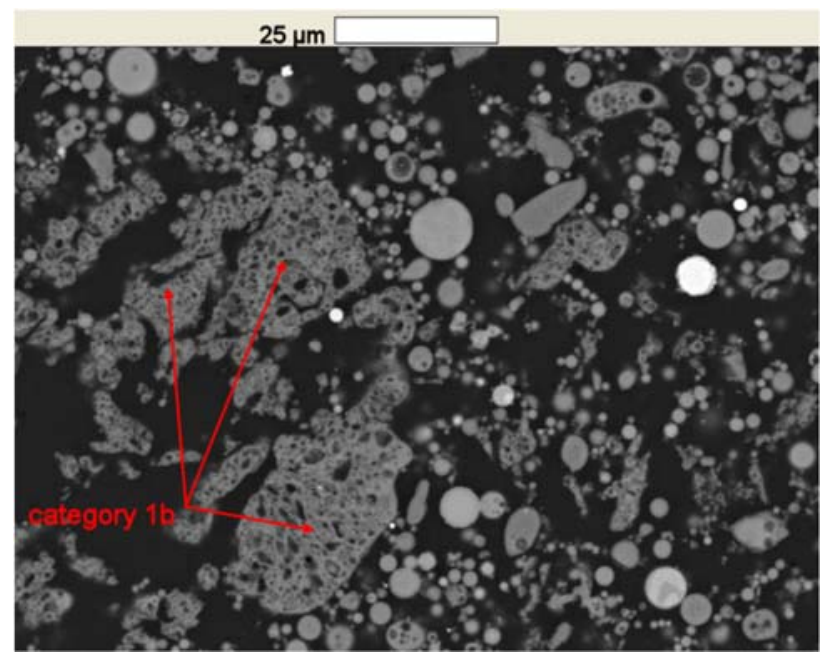

Figure 4.E.2 Deposit co-firing coal with MBM and biomass pellets, ('test MV1-1'), back scatter image. Top: upstream deposit, bottom: downstream deposit. Deposits from upper probe (see Figure A.2). 
Table 4.E.1 Observations microscopic analysis of deposits

\begin{tabular}{|c|c|c|c|}
\hline & A9-2 & A9-1 & MV1-1 \\
\hline fuels & coal & coal and wood & coal and MBM-mix \\
\hline exposure time & 1 week & 4 weeks & $24 \mathrm{hrs}$ \\
\hline probes & 1 & 1 & 2 \\
\hline \multicolumn{4}{|l|}{ upstream deposits } \\
\hline $\begin{array}{l}\text { max. deposit } \\
\text { thickness }(\mu \mathrm{m})\end{array}$ & $250-350$ & 8,600 & $1,000 / 1,000$ \\
\hline $\begin{array}{l}\text { typical diameter } \\
\text { particles }(\mu \mathrm{m})\end{array}$ & $50-75$ & differ per area & $<15$ and of $50-75$ \\
\hline $\begin{array}{l}\text { concentration main } \\
\text { elements }\end{array}$ & $\begin{array}{l}\text { Fe }(20 \%), \text { Si }(5 \%), \text { Al } \\
(3 \%), \quad \text { Ca }(3 \%), \quad M g \\
(1 \%), S(1 \%)\end{array}$ & $\begin{array}{l}\text { Si }(12 \%), \mathrm{Fe}(9 \%), \mathrm{Al} \\
(8 \%), \quad \mathrm{Ca}(3 \%), \quad \mathrm{Mg} \\
(1 \%), \mathrm{S}(1 \%)\end{array}$ & $\begin{array}{l}\text { Si }(10 \%), \mathrm{Fe}(6 \%), \mathrm{Ca} \\
(6 \%), \mathrm{Al}(5 \%), \mathrm{P}(3 \%), \\
\mathrm{Na}(1 \%), \mathrm{Mg}(1 \%), \mathrm{S} \\
(1 \%)\end{array}$ \\
\hline shape & flat layer & wedge & wedge \\
\hline porosity & not porous & varying & varying \\
\hline \multicolumn{4}{|l|}{ downstream deposits } \\
\hline $\begin{array}{l}\text { max. deposit } \\
\text { thickness }(\mu \mathrm{m})\end{array}$ & 1,000 & 0 & $100 / 0$ \\
\hline $\begin{array}{l}\text { typical diameter } \\
\text { particles downstream } \\
\text { deposit }(\mu \mathrm{m})\end{array}$ & $<10$ & - & $<10$ \\
\hline $\begin{array}{ll}\text { concentration main } \\
\text { elements }\end{array}$ & $\begin{array}{l}\text { Si }(10 \%), \text { Al }(7 \%), \mathrm{Ca} \\
(1 \%), \mathrm{Fe}(1 \%)\end{array}$ & - & $\begin{array}{l}\text { Si }(17 \%), \mathrm{Al}(8 \%), \\
(2 \%), \quad \mathrm{Ne}(2 \%), \\
(2 \%), \quad \mathrm{Ca}(1 \%), \\
(1 \%), \mathrm{S}(1 \%) /-\end{array}$ \\
\hline shape & flat layer & - & flat layer / - \\
\hline porosity & very porous & - & very porous / - \\
\hline
\end{tabular}



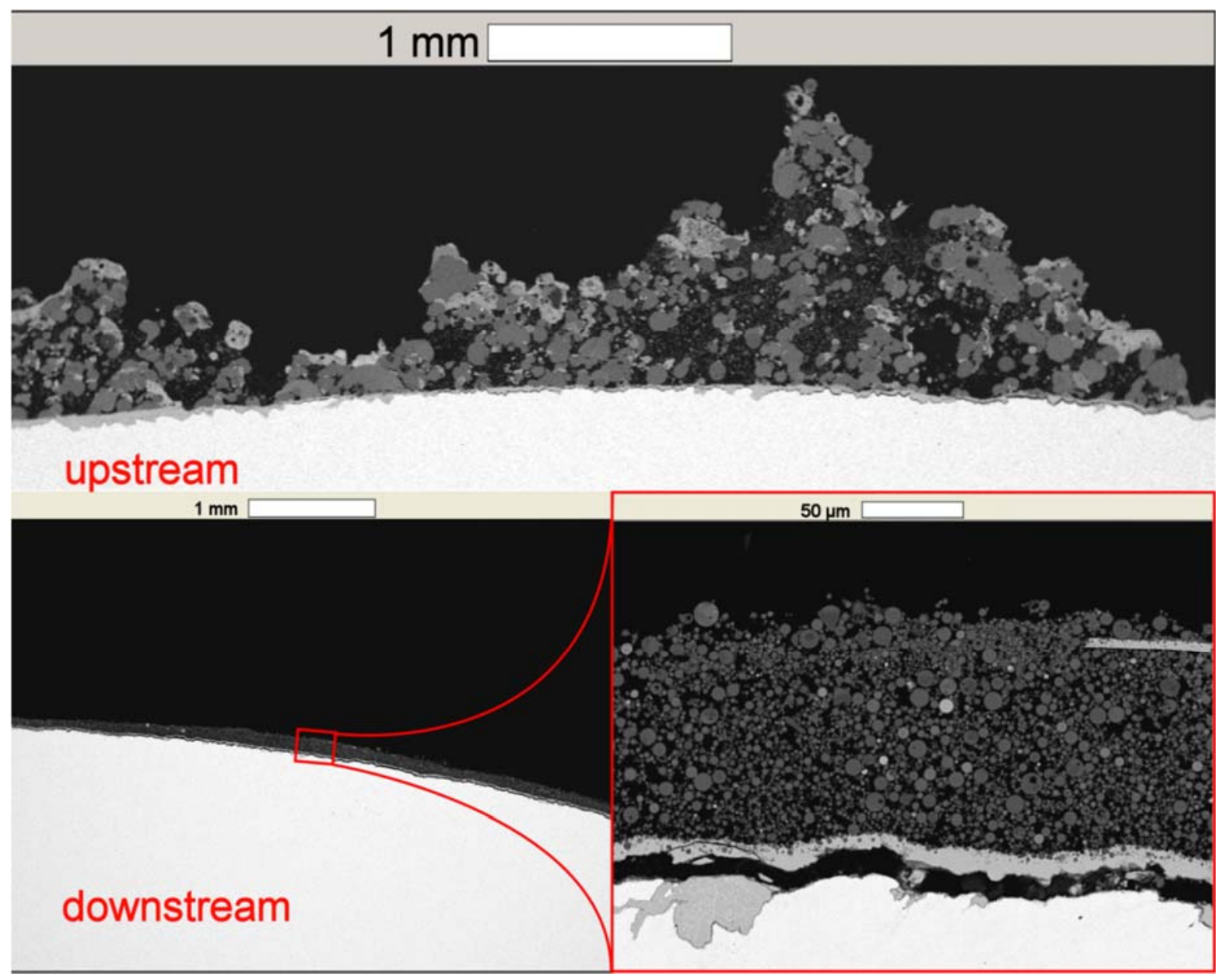

Figure 4.E.3 Superheater probe deposit coal firing (test A9-2). Outer side of deposit; back scatter image. Al and Si-rich porous and arbitrarily shaped particles (category $1 \mathrm{~b}$ ) are indicated; BE image. 


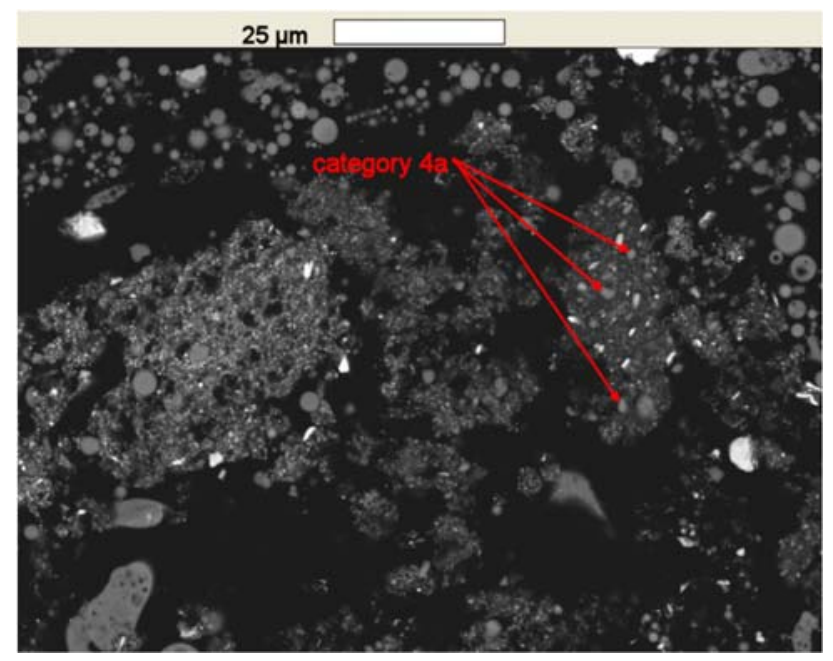

Figure 4.E.4 Deposit coal firing (test A9-2), downstream deposit; back scatter image. Ca and C rich particles (category $4 a$ ).

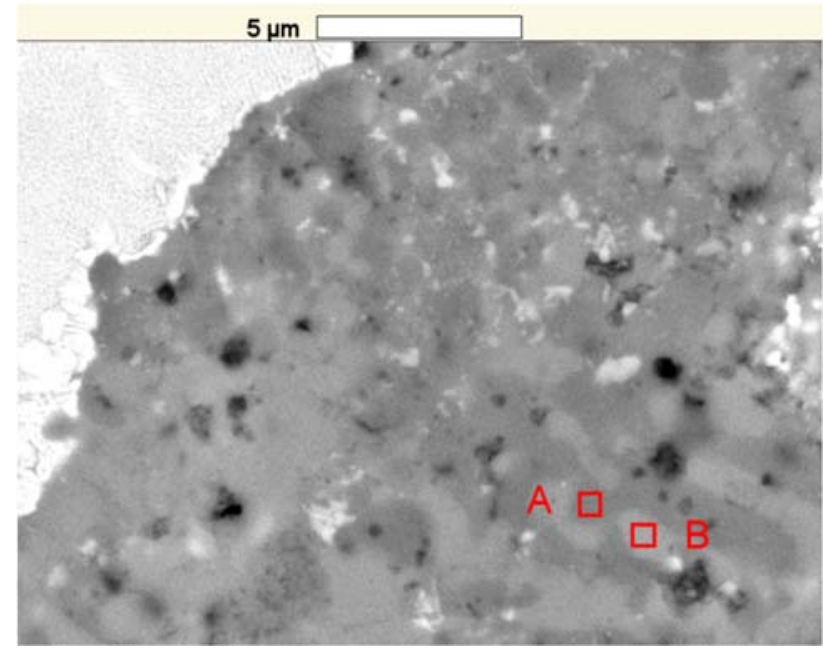

Figure 4.E.5 Deposit co-firing wood with coal (test A9-1), initial deposit; back scatter image. Typical example of area rich in $\mathrm{Ca}, \mathrm{S}$ and $\mathrm{O}$, and varying concentrations of $(\mathrm{Al}+$ Si) (category 4b). Elemental composition: A) 5-7\% Ca, 2-4\% S, 64-67\% O, 22$26 \%$ (Al+Si); B) 7-13\% Ca, 4-13\% S, 67-71\% O, 6-20\% (Al+Si). 
Appendix 4.F Thermodynamic calculation results

Table 4.F.1 Thermodynamic equilibrium results for temperature region $1,700-900^{\circ} \mathrm{C}$. Indicated are temperature regions in which compounds are stable.

\begin{tabular}{|c|c|c|c|c|c|c|}
\hline \multirow[b]{2}{*}{ compound } & \multicolumn{2}{|c|}{ Coal firing } & \multicolumn{2}{|c|}{ Co-firing $12 \%$ wood } & \multicolumn{2}{|c|}{ Co-firing 4\% MBM-mix } \\
\hline & oxi & red & oxi & red & oxi & red \\
\hline Slag-Si & $\leq 1,700$ & $\leq 1,700$ & $\leq 1,700$ & $\leq 1,700$ & $\leq 1,700$ & $\leq 1,700$ \\
\hline Slag - Al & $\leq 1,700$ & $\leq 1,700$ & $\leq 1,700$ & $\leq 1,700$ & $\leq 1,700$ & $\leq 1,700$ \\
\hline Tridymite $\left(\mathrm{SiO}_{2}(\mathrm{~s})\right)$ & $\leq 1,080$ & $\leq 950$ & $\leq 1,210$ & $\leq 1,210$ & $\leq 1,170$ & $\leq 1,100$ \\
\hline Mullite $\left(\mathrm{Al}_{6} \mathrm{Si}_{2} \mathrm{O}_{13}(\mathrm{~s})\right)$ & $\leq 1,330$ & $\leq 1,300$ & $\leq 1,560$ & $\leq 1,570$ & $\leq 1,490$ & $\leq 1,475$ \\
\hline K-feldspar $\left(\mathrm{KAISi}_{3} \mathrm{O}_{8}(\mathrm{~s})\right)$ & $\leq 980$ & $\leq 905$ & $\leq 1,040$ & $\leq 950$ & $\leq 1,010$ & - \\
\hline Spinel $\left(\mathrm{MgAl}_{2} \mathrm{O}_{4}(\mathrm{~s})\right)$ & $\leq 900$ & - & - & - & $\leq 970$ & - \\
\hline Slag - Fe & $\geq 990$ & $\leq 1,700$ & $\geq 910$ & $\leq 1,700$ & $\geq 960$ & $\leq 1,700$ \\
\hline $\mathrm{Fe}(\mathrm{OH})_{2}(\mathrm{~g})$ & $>1,160^{*}$ & $>970^{*}$ & $>1,100^{*}$ & $>920^{*}$ & $>1,110^{*}$ & $>940^{*}$ \\
\hline $\mathrm{FeO}(\mathrm{g})$ & $>1,570^{*}$ & $>1,590^{*}$ & $>1,580^{*}$ & $>1,600^{*}$ & $>1,570^{*}$ & $>1,600^{*}$ \\
\hline $\mathrm{Fe}(\mathrm{g})$ & $-*$ & $>1,440^{*}$ & $-^{*}$ & $>1,430^{*}$ & $-*$ & $>1,410^{*}$ \\
\hline $\mathrm{Fe}_{2} \mathrm{O}_{3}(\mathrm{~s})$ & $\leq 1,330$ & - & $\leq 1,240$ & - & $\leq 1,260$ & - \\
\hline $\mathrm{FeAl}_{2} \mathrm{O}_{4}(\mathrm{~s})$ & - & $\leq 950$ & - & - & - & - \\
\hline Slag - Ti & $\leq 1,700$ & $\leq 1,700$ & $\leq 1,700$ & $\leq 1,700$ & $\leq 1,700$ & $\leq 1,700$ \\
\hline $\mathrm{TiO}_{2}(\mathrm{~s})$ & - & - & $\leq 950$ & - & $\leq 940$ & - \\
\hline Slag Ca & $\leq 1,700$ & $\leq 1,700$ & $\leq 1,700$ & $\leq 1,700$ & $\leq 1,700$ & $\leq 1,700$ \\
\hline $\mathrm{Ca}_{3}\left(\mathrm{PO}_{4}\right)_{2}(\mathrm{~s})$ & $\leq 1,080$ & - & $\leq 1,060$ & - & $\leq 1,070$ & - \\
\hline Slag - P & $\geq 990$ & $\leq 1,700$ & $\geq 910$ & $\leq 1,700$ & $\geq 960$ & $\leq 1,700$ \\
\hline Slag - Mg & $\leq 1,700$ & $\leq 1,700$ & $\leq 1,700$ & $\leq 1,700$ & $\leq 1,700$ & $\leq 1,700$ \\
\hline Slag - Na & $\leq 1,700$ & $\leq 1,700$ & $\leq 1,700$ & $\leq 1,700$ & $\leq 1,700$ & $\leq 1,700$ \\
\hline $\mathrm{Na}(\mathrm{g})$ & $>1,520^{*}$ & $>1,340^{*}$ & $>1,540^{*}$ & $>1,320^{*}$ & $>1,540^{*}$ & $>1,325^{*}$ \\
\hline $\mathrm{NaOH}(\mathrm{g})$ & $>1,290^{*}$ & $>1,330^{*}$ & $>1,250^{*}$ & $>1,300^{*}$ & $>1,260^{*}$ & $>1,325^{\star}$ \\
\hline $\mathrm{NaCl}(\mathrm{g})$ & $>1,060^{*}$ & $>1,060^{*}$ & $\leq 1,700$ & $\leq 1,700$ & $\leq 1,700$ & $\leq 1,700$ \\
\hline Slag - K & $\leq 1,700$ & $\leq 1,700$ & $\leq 1,700$ & $\leq 1,700$ & $\leq 1,700$ & $\leq 1,700$ \\
\hline $\mathrm{K}(\mathrm{g})$ & $>1,580^{*}$ & $>1,400^{*}$ & $>1,590^{*}$ & $>1,420^{*}$ & $>1,600^{*}$ & $>1,400^{*}$ \\
\hline $\mathrm{KOH}(\mathrm{g})$ & $>1,300^{*}$ & $>1,310^{*}$ & $>1,310^{*}$ & $>1,340^{*}$ & $>1,310^{*}$ & $>1,325^{\star}$ \\
\hline $\mathrm{KCl}(\mathrm{g})$ & $>1,190^{*}$ & $>1,140^{*}$ & $>1,030^{*}$ & $>1,240^{*}$ & $>1,020^{*}$ & $>1,025^{*}$ \\
\hline $\mathrm{SO}_{2}(\mathrm{~g})$ & $\leq 1,700$ & $>980^{*}$ & $\leq 1,700$ & $>980^{*}$ & $\leq 1,700$ & $>1,000^{*}$ \\
\hline $\mathrm{SO}(\mathrm{g})$ & - & $>1,210^{*}$ & - & $>1,210^{*}$ & - & $>1,225^{*}$ \\
\hline $\mathrm{H}_{2} \mathrm{~S}(\mathrm{~g})$ & - & $<1,530^{*}$ & - & $<1,540^{*}$ & - & $<1,600^{*}$ \\
\hline $\cos (g)$ & - & $<1,420^{*}$ & - & $<1,420^{*}$ & - & $<1,475^{\star}$ \\
\hline $\mathrm{HCl}(\mathrm{g})$ & $\leq 1,700$ & $\leq 1,700$ & $\leq 1,700$ & $\leq 1,700$ & $\leq 1,700$ & $\leq 1,700$ \\
\hline
\end{tabular}

* Temperature region at which the amount of the component is more than $1 \%$ of the total amount of gaseous components at $1,700{ }^{\circ} \mathrm{C}$ in which the element of interest $(\mathrm{Fe}, \mathrm{Na}, \mathrm{K}, \mathrm{S}$, or $\mathrm{Cl})$ is incorporated 
coal

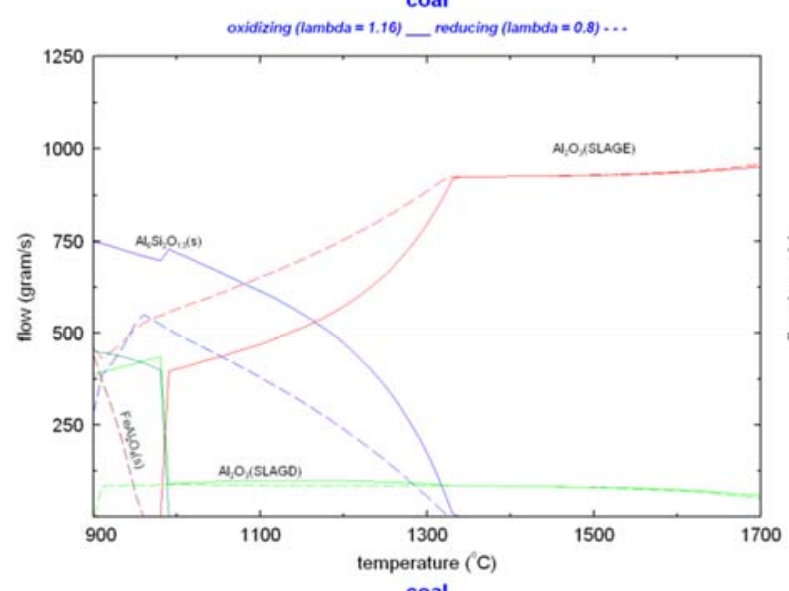

coal
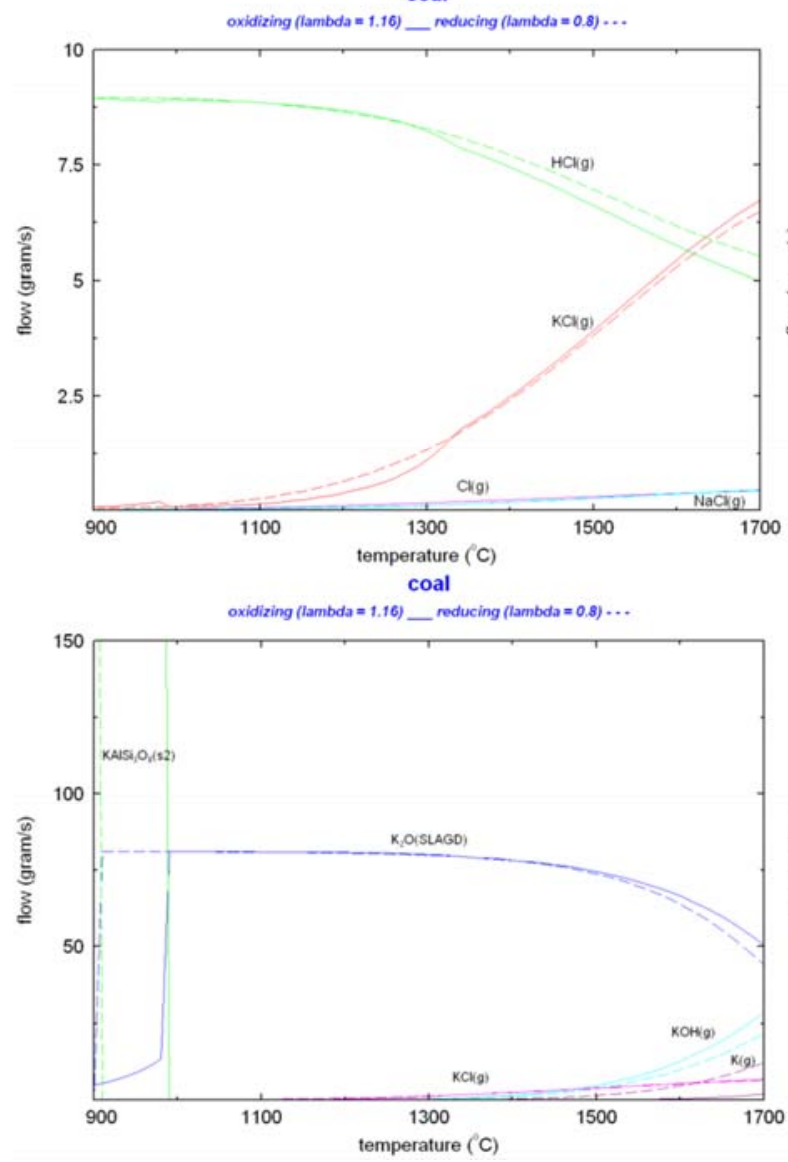

coal

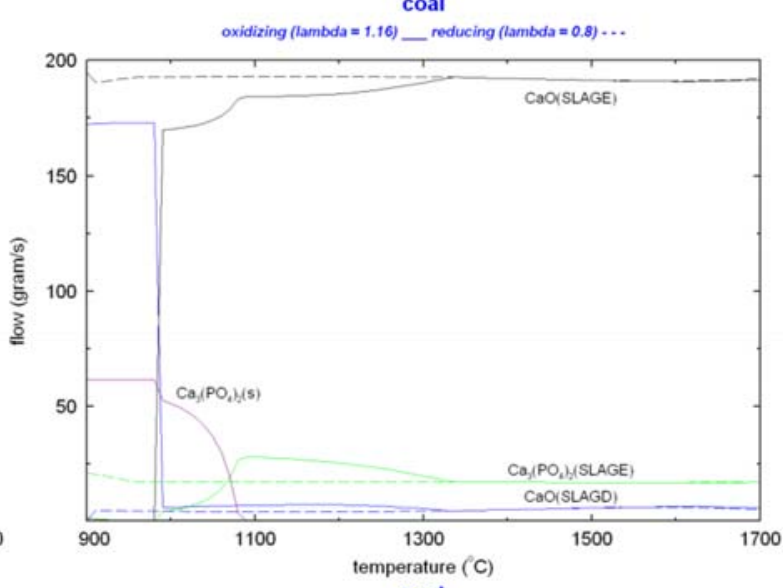

oxidizing (lambda $=1.16)$ _educing $($ lambda $=0.8) \ldots$
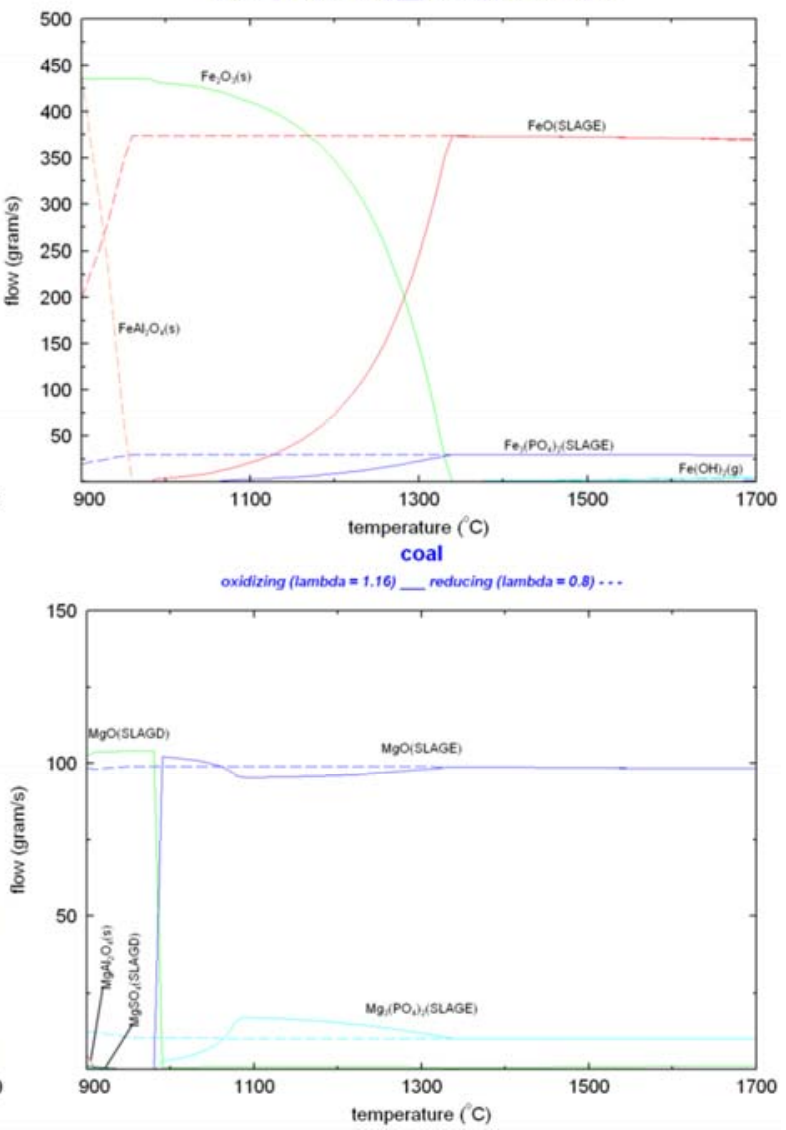

Figure 4.F.1 Thermodynamic equilibrium diagrams $900-1,700^{\circ} \mathrm{C}$; coal firing. 
coal

oxidizing (lambda $=1.16)$ reducing (lambda $=0.8) \ldots$

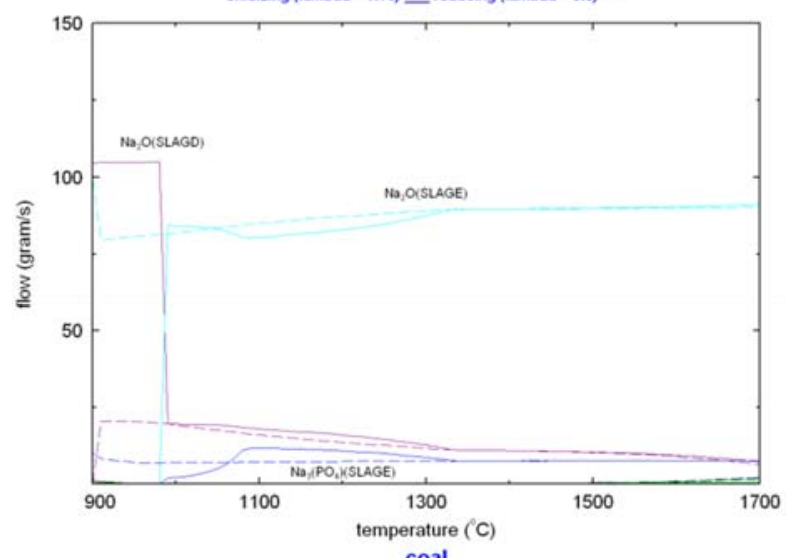

coal
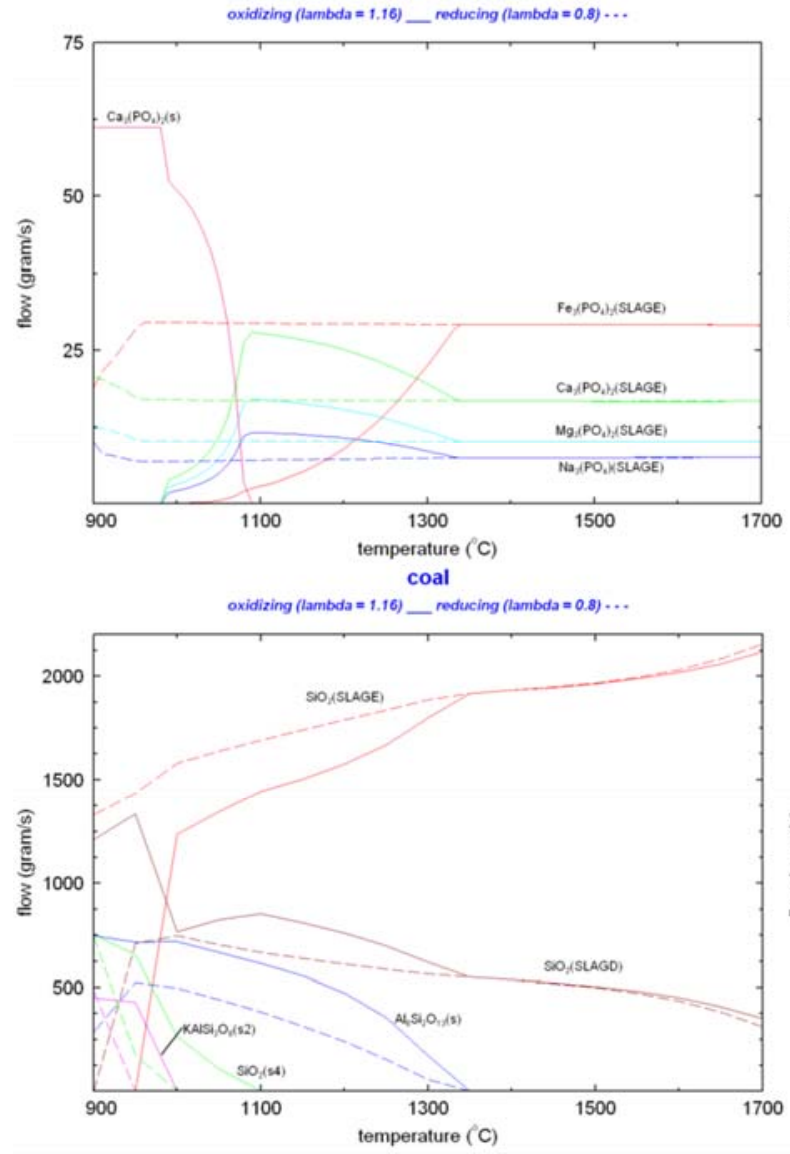

coal

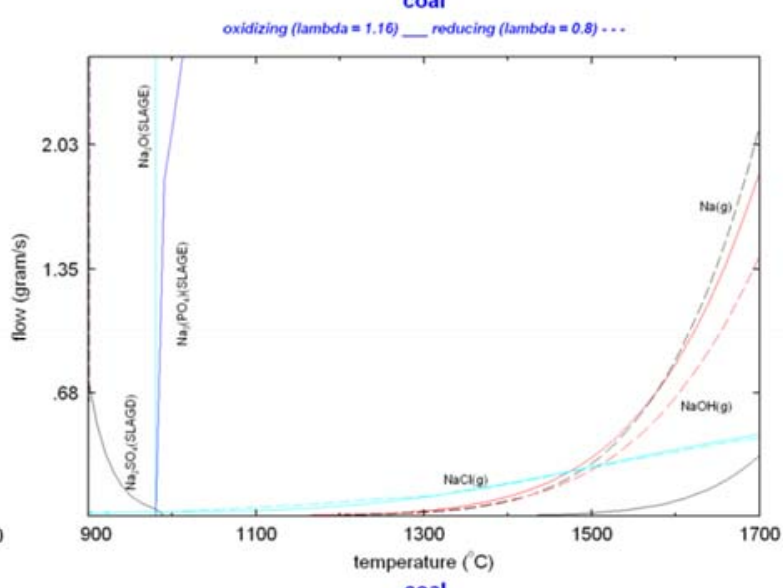

oxidizing (lambda $=1.16)$ _ reducing (lambda $=0.8) \ldots$
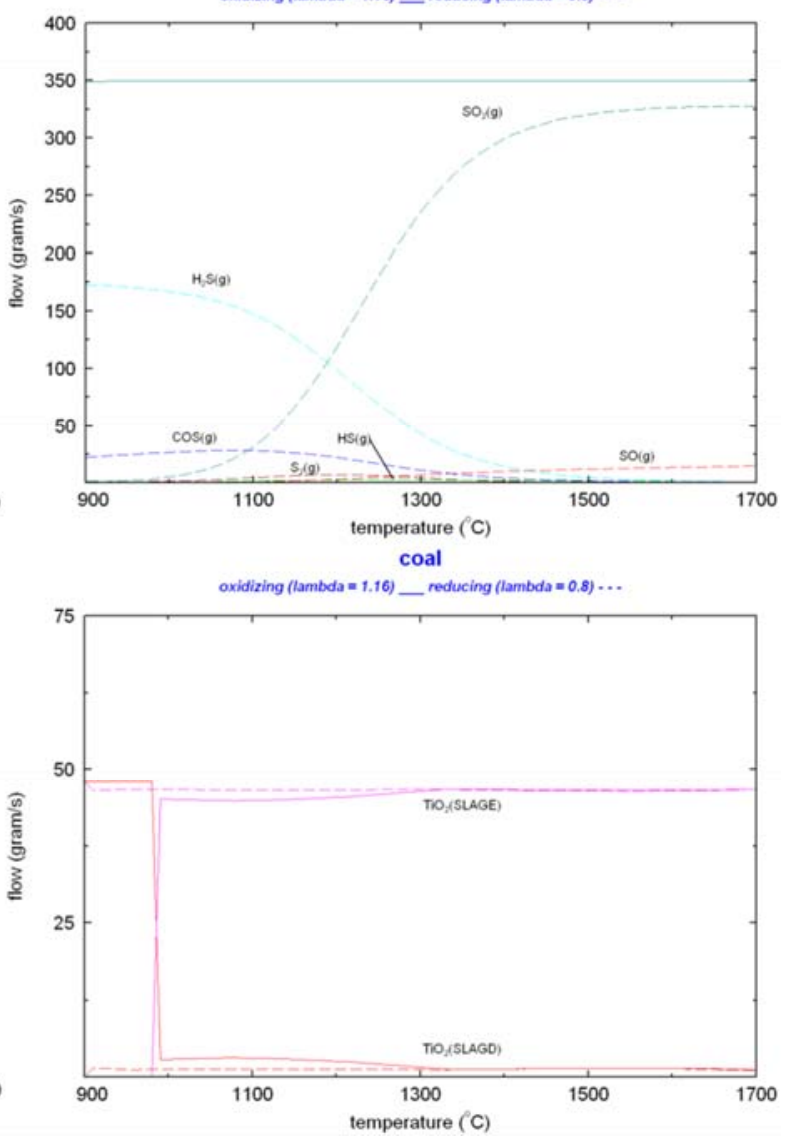

Figure 4.F.2 Thermodynamic equilibrium diagrams $900-1,700^{\circ} \mathrm{C}$; coal firing. 

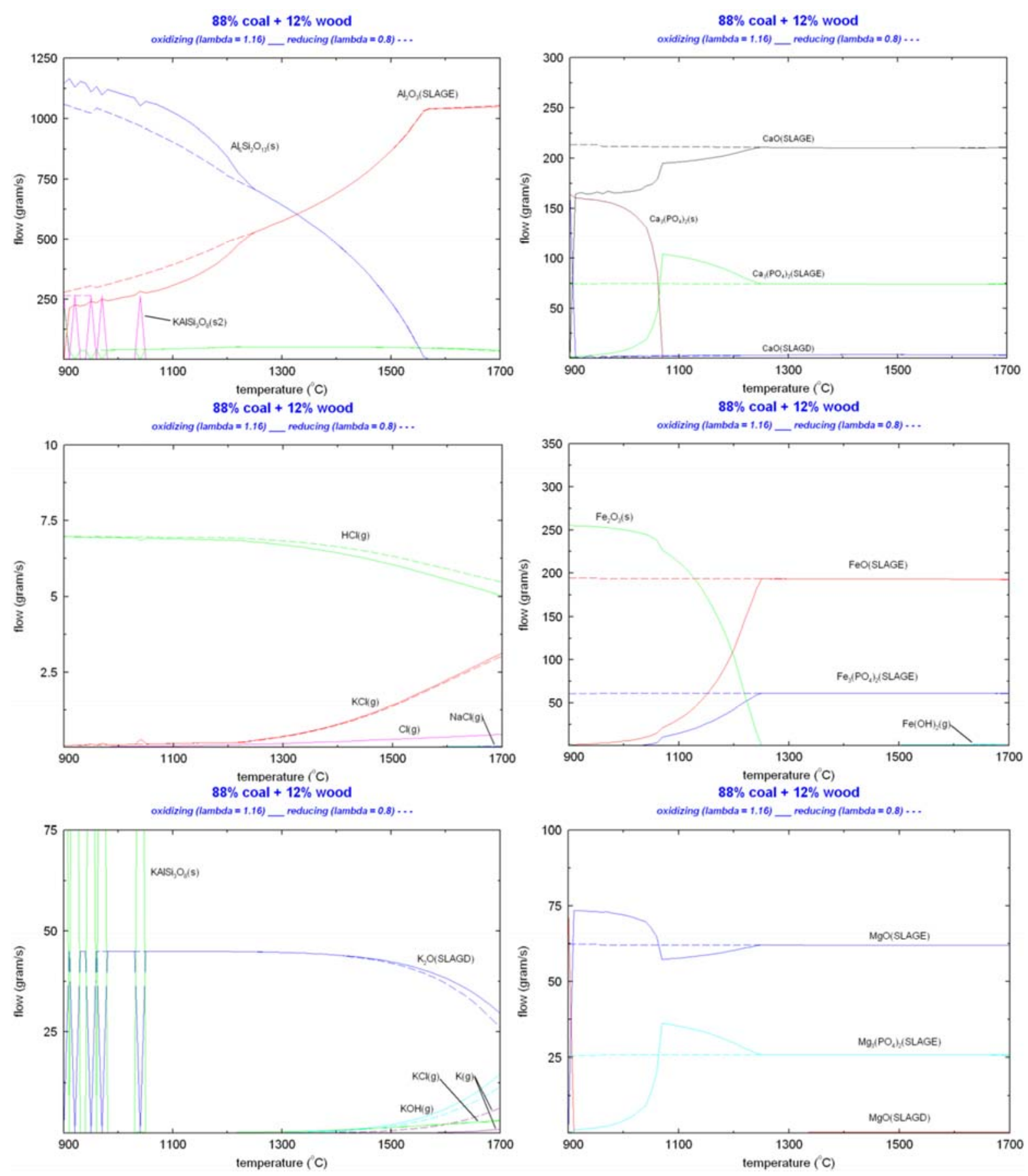

Figure 4.F.3 Thermodynamic equilibrium diagrams $900-1,700{ }^{\circ} \mathrm{C}$; co-firing wood. 

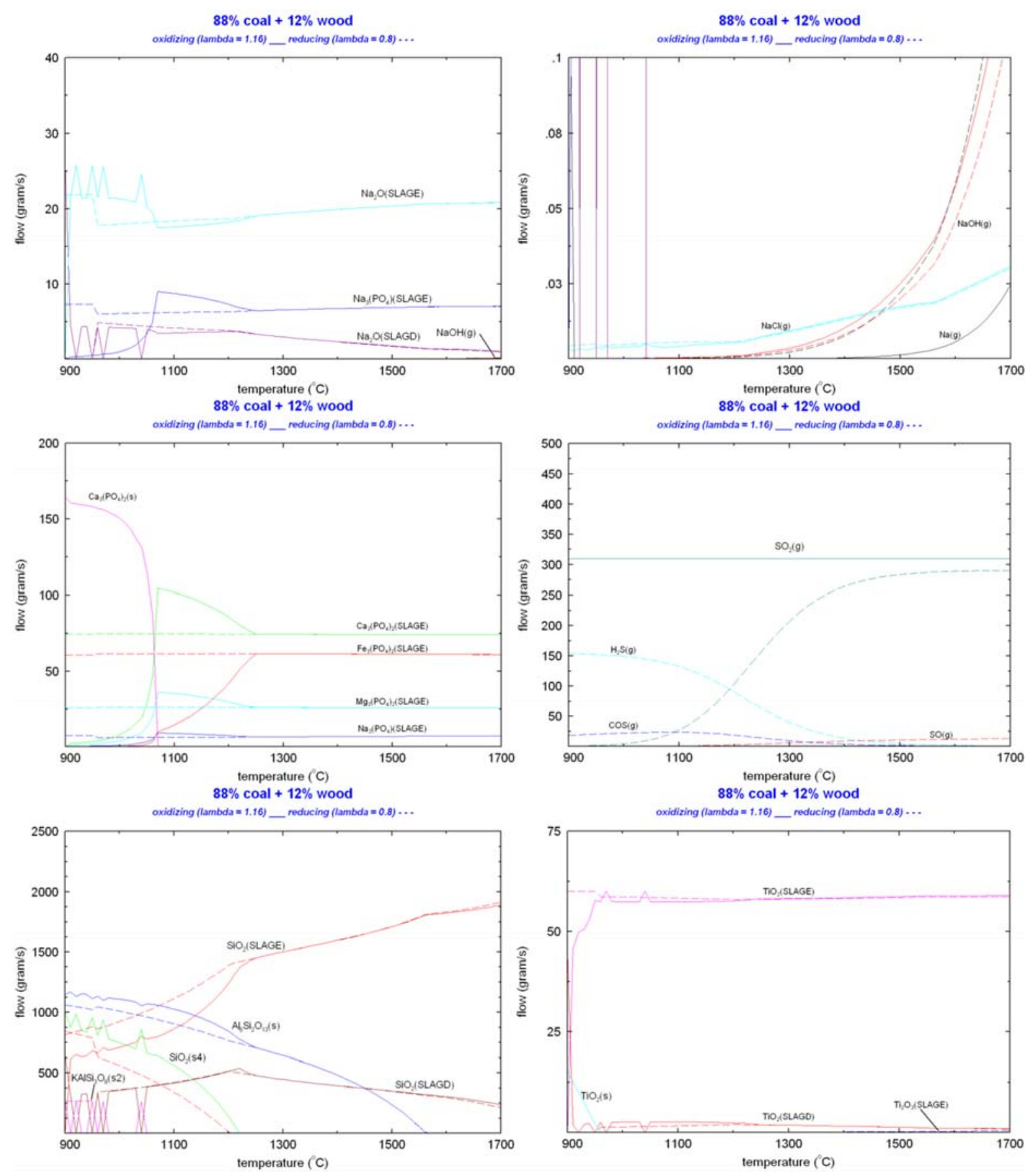

Figure 4.F.4 Thermodynamic equilibrium diagrams $900-1700^{\circ} \mathrm{C}$; co-firing wood. 

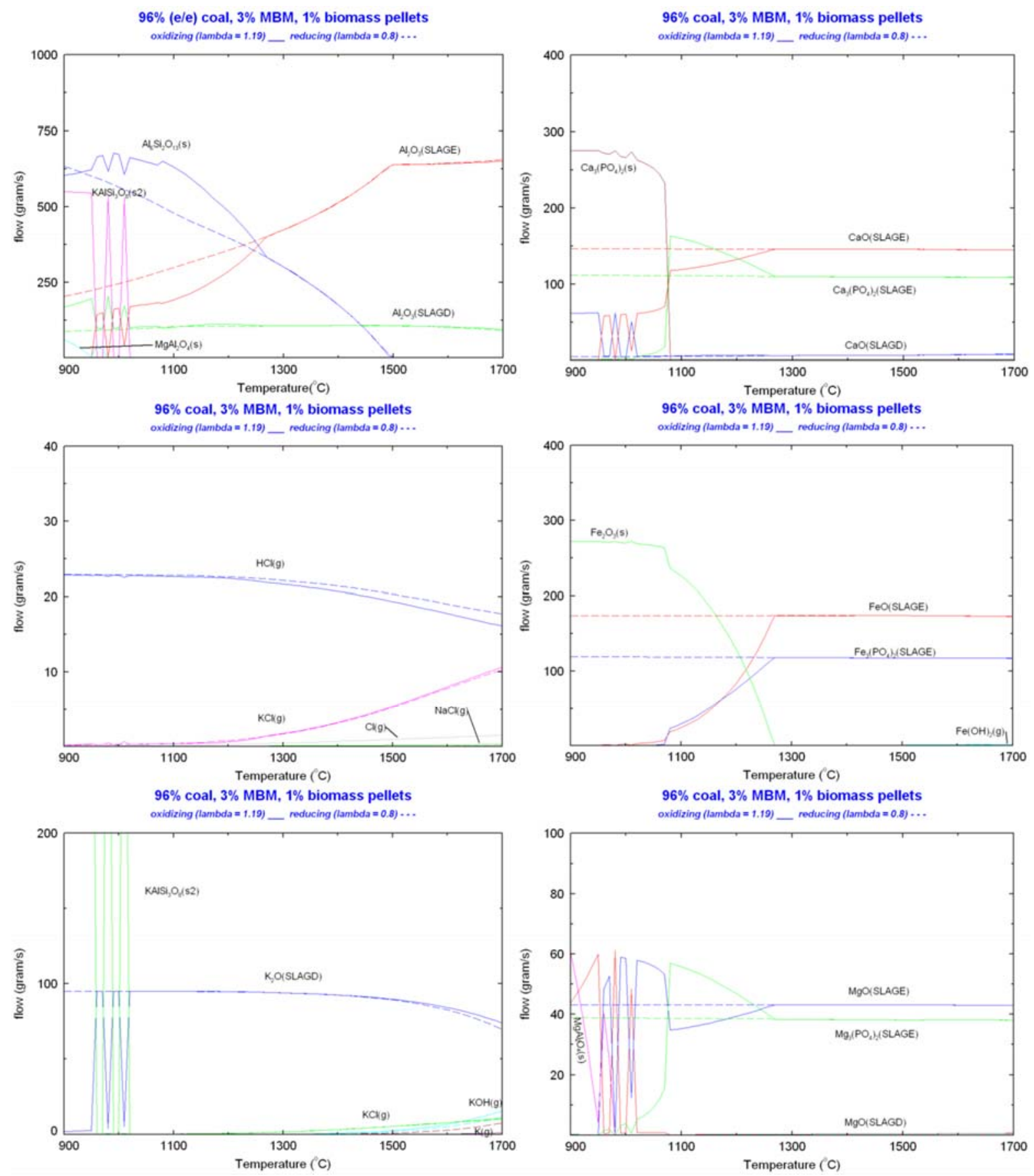

Figure 4.F.5 Thermodynamic equilibrium diagrams $900-1,700^{\circ} \mathrm{C}$; co-firing MBM-mix. 

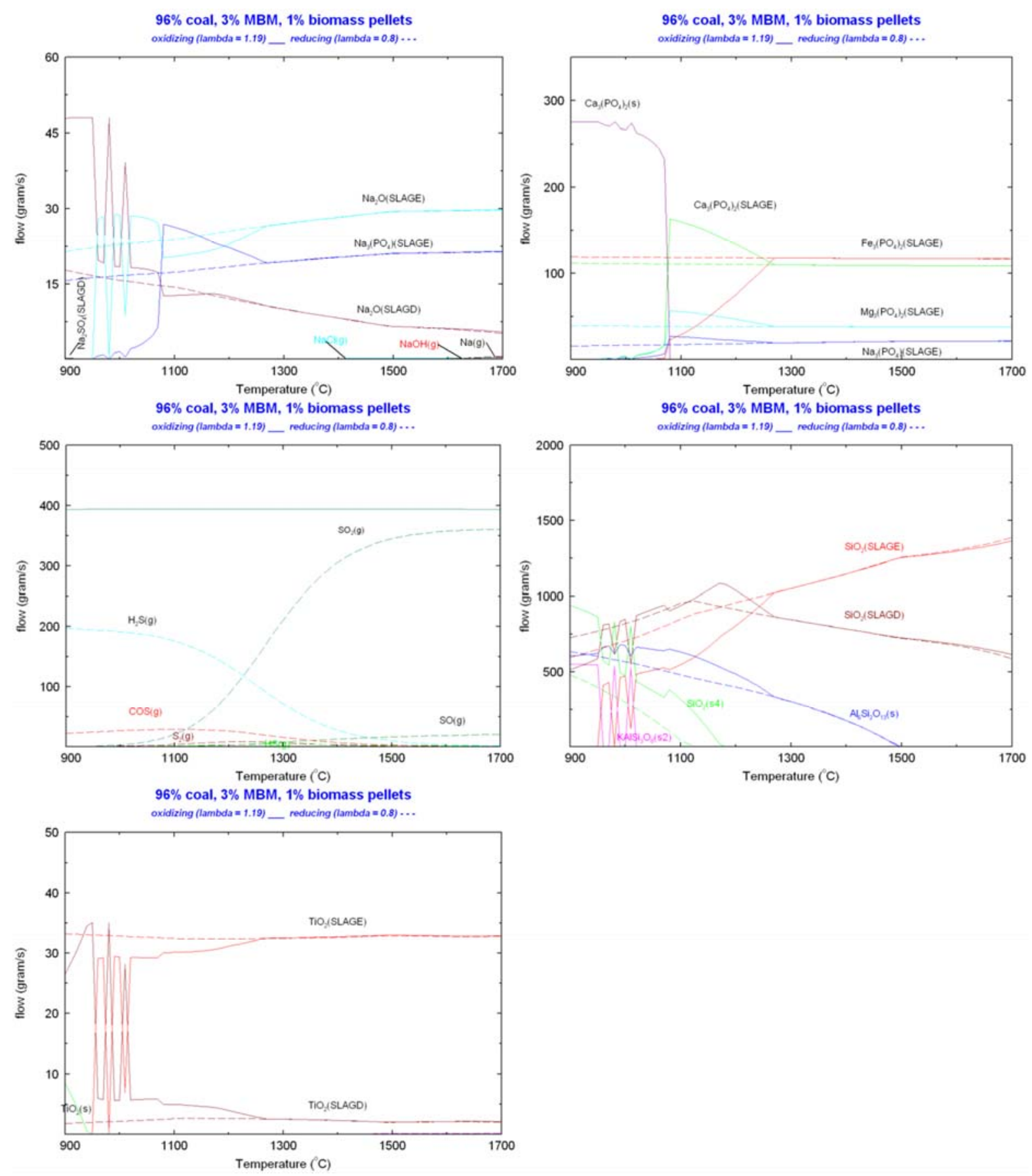

Figure 4.F.6 Thermodynamic equilibrium diagrams $900-1,700{ }^{\circ} \mathrm{C}$; co-firing MBM-mix. 


\section{Appendix to chapter 5}

Appendix 5.A Typical fuel compositions

Table 5.A.1 Typical fuel compositions

\begin{tabular}{lllll}
\hline & coal & wood & sheanut-mix & MBM-mix \\
\hline LHV (MJ/kg) & 25 & 19.0 & 18.2 & 15.5 \\
moisture (a.r., \%) & 10.5 & 5.9 & 2.9 & 10.4 \\
ash (a.r., \%) & 12.2 & 0.8 & 6.5 & 18.0 \\
$\mathrm{C}$ (d.a.f., \%) & 71.8 & 51.2 & 47.4 & 42.2 \\
$\mathrm{H}$ (d.a.f., \%) & 4.6 & 6.15 & 3.79 & 5.74 \\
$\mathrm{~N}$ (d.a.f., \%) & 1.6 & 0.15 & 2.40 & 5.21 \\
$\mathrm{~S}$ (d.a.f., \%) & 0.84 & 0.06 & 0.25 & 0.39 \\
$\mathrm{Al}$ (a.r., \%) & 1.75 & 0.01 & 0.09 & 0.48 \\
$\mathrm{Ca}$ (a.r., \%) & 0.35 & 0.57 & 0.29 & 3.16 \\
$\mathrm{Cl}$ (a.r., \%) & 0.024 & 0.035 & 0.106 & 0.325 \\
Fe (a.r., \%) & 0.6 & 0.03 & 0.17 & 0.33 \\
$\mathrm{~K}$ (a.r., \%) & 0.16 & 0.12 & 1.93 & 0.81 \\
$\mathrm{Mg}$ (a.r., \%) & 0.11 & 0.05 & 0.36 & 0.22 \\
$\mathrm{Na}$ (a.r., \%) & 0.05 & 0.01 & 0.01 & 0.27 \\
$\mathrm{P}$ (a.r., \%) & 0.04 & 0.03 & 0.46 & 1.56 \\
$\mathrm{Si}($ a.r., \%) & 3.18 & 0.16 & 0.48 & 1.87 \\
Ti (a.r., \%) & 0.08 & 0.00 & 0.00 & 0.01 \\
\hline
\end{tabular}

Table 5.A.2 Average coal fly ash composition originating from Dutch coal-fired power plants, mass\% (source: [Sarabèr, 2017])

\begin{tabular}{ll}
\hline oxide & percentage \\
\hline $\mathrm{SiO}_{2}$ & $55 \%$ \\
$\mathrm{Al}_{2} \mathrm{O}_{3}$ & $27 \%$ \\
$\mathrm{Fe}_{2} \mathrm{O}_{3}$ & $7.3 \%$ \\
$\mathrm{CaO}$ & $4.5 \%$ \\
$\mathrm{MgO}$ & $1.5 \%$ \\
$\mathrm{Na}_{2} \mathrm{O}$ & $0.6 \%$ \\
$\mathrm{~K}_{2} \mathrm{O}$ & $1.6 \%$ \\
$\mathrm{P}_{2} \mathrm{O}_{5}$ & $0.77 \%$ \\
$\mathrm{Cl}$ & $0.01 \%$ \\
$\mathrm{SO}_{3}$ & $0 \%$ \\
\hline
\end{tabular}


Appendix 5.B Selected compounds in equilibrium calculations

Table 5.B.1 Selected compounds in FactSage equilibrium calculations

\begin{tabular}{|c|c|}
\hline gas & 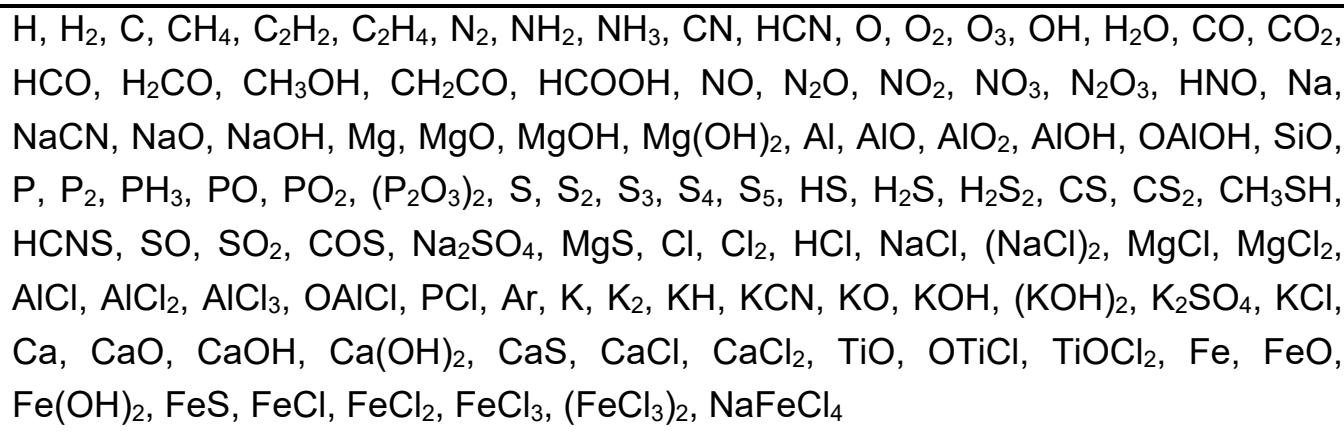 \\
\hline solu & SLAG D, SLAG E \\
\hline solid & 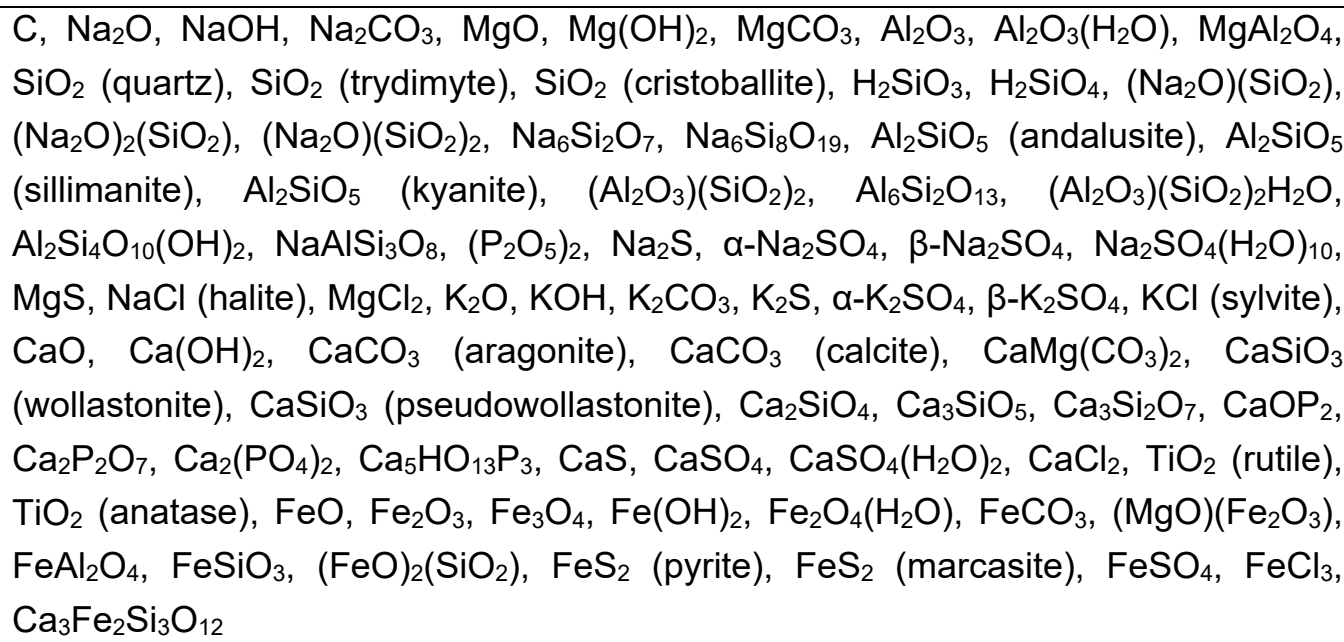 \\
\hline
\end{tabular}


Appendix 5.C Element availability

The available mass of an element in a formed mineral is calculated by multiplying $1 \mathrm{~kg}$ fuel ash, the concentration of the mineral in the fuel ash (HTA, High Temperature Ash), the (stoichiometric) concentration of the element in a mineral and the change of the mineral $\Delta$ (based on concentration in HTA and FA (Fly Ash)), see Table 5.C.1. That is done for all the minerals that are formed in which the element is present. For example, Fe is present in the formed minerals melilite and magnetite. These masses are summed and the sum is divided by the total mass of the element in $1 \mathrm{~kg}$ of fuel ash. This yields the availability of an element based on formed minerals. In a formula:

$$
\begin{aligned}
\text { for }[\mathrm{min}]_{\mathrm{HTA}}- & {[\mathrm{min}]_{\mathrm{FA}}>0, } \\
\mathrm{AF}_{\text {transformed,element } \mathrm{x}} & =\frac{\sum_{\mathrm{min}=1}^{\mathrm{m}} \frac{[\mathrm{min}]_{\mathrm{HTA}}-[\mathrm{min}]_{\mathrm{FA}}}{[\mathrm{min}]_{\mathrm{HTA}}}[\mathrm{min}]_{\mathrm{HTA}}[\text { element } \mathrm{x}]_{\mathrm{min}}}{[\text { element } \mathrm{x}]_{\mathrm{HTA}}}
\end{aligned}
$$

where [] denotes concentration and the subscript in min: mineral, FA: Fly Ash, HTA: High Temperature Ash. The same can be done for transformed ((partly) disappeared) minerals (for example, for $\mathrm{Fe}$ these are hematite, siderite and ankerite), yielding the availability of an element based on transformed minerals. In a similar formula:

$$
\begin{aligned}
& \text { for }[\min ]_{\mathrm{HTA}}-[\mathrm{min}]_{\mathrm{FA}}<0, \\
& \mathrm{AF}_{\text {formed,element } \mathrm{x}}=\frac{\sum_{\mathrm{min}=1}^{\mathrm{p}} \frac{[\mathrm{min}]_{\mathrm{FA}}-[\mathrm{min}]_{\mathrm{HTA}}}{[\mathrm{min}]_{\mathrm{FA}}}[\mathrm{min}]_{\mathrm{FA}}[\text { element } \mathrm{x}]_{\mathrm{min}}}{[\text { element } \mathrm{x}]_{\mathrm{FA}}}
\end{aligned}
$$

The maximum of these two availabilities (based on formation and transformation) is then used as 'the availability' of an element. As a last step, the calculated availabilities were averaged on the five different fuel ash and fly ash combinations in the dataset of [Vassilev et al., 2003]. In a general formula:

$$
\mathrm{AF}_{\text {element } \mathrm{x}}=\sum_{\mathrm{j}=1}^{\mathrm{n}} \frac{\max \left\{\mathrm{AF}_{\text {formed,element } \mathrm{x}}, \mathrm{AF}_{\text {transformed,element } \mathrm{x}}\right\}}{\mathrm{n}}
$$


Table 5.C.1 Mineral change based on comparisons between five pairs of high temperature ash of coal and resulting fly ash, source: [Vassilev et al., 2003].

\begin{tabular}{|c|c|c|c|c|c|c|c|c|c|c|c|c|c|c|c|c|}
\hline \multirow[t]{3}{*}{ mineral } & \multirow[t]{3}{*}{ formula } & \multicolumn{3}{|c|}{ Coal1 } & \multicolumn{3}{|l|}{ Coal2 } & \multicolumn{3}{|l|}{ Coal3 } & \multicolumn{3}{|l|}{ Coal4 } & \multicolumn{3}{|c|}{ Coal5 } \\
\hline & & HTA & $\mathrm{F}$ & $\Delta(\%)$ & HTA & $\mathrm{FA}$ & $\Delta(\%)$ & HTA & $\mathrm{F}$ & $\Delta(\%)$ & HTA & $\mathrm{F}$ & $\Delta(\%)$ & HTA & $\mathrm{F}$ & $\Delta(\%)$ \\
\hline & & & A & & & & & & A & & & A & & & A & \\
\hline \multirow[t]{2}{*}{ Amorphous } & - & 26 & 6 & & 23 & 69 & & 23 & 6 & & 17 & 7 & & 17 & 6 & \\
\hline & & & 4 & & & & & & 8 & & & 8 & & & 7 & \\
\hline \multirow[t]{2}{*}{ Quartz } & $\mathrm{SiO}_{2}$ & 28 & 1 & -62 & 32 & 11 & -65 & 18 & 1 & -38 & 38 & 5 & -86 & 32 & 9 & -72 \\
\hline & & & 1 & & & & & & 1 & & & & & & & \\
\hline \multirow[t]{2}{*}{ Cristobalite } & $\mathrm{SiO}_{2}$ & 0 & 1 & +10 & 0 & 1 & +100 & 0 & 1 & +100 & 0 & 1 & +100 & 0 & 1 & +100 \\
\hline & & & & 0 & & & & & & & & & & & & \\
\hline Kaolinite & $\mathrm{Al}_{2} \mathrm{Si}_{2} \mathrm{O}_{5}(\mathrm{OH})_{4}$ & 8 & 2 & -73 & 9 & 2 & -74 & 15 & 1 & -93 & 10 & 1 & -87 & 9 & 1 & -88 \\
\hline $\begin{array}{l}\text { Illite }+ \\
\text { muscovite }\end{array}$ & $\mathrm{KAl}_{2}\left(\mathrm{Si}_{3}, \mathrm{Al}\right) \mathrm{O}_{10}(\mathrm{OH})_{2}$ & 6 & 0 & -100 & 10 & 0 & -100 & 6 & 0 & -100 & 9 & 0 & -100 & 7 & 0 & -100 \\
\hline \multirow[t]{2}{*}{ Mullite } & $\mathrm{Al}_{4.5} \mathrm{Si}_{1.5} \mathrm{O}_{9.75}$ & 0 & 1 & +10 & 0 & 9 & +100 & 0 & 1 & +100 & 0 & 8 & +100 & 0 & 1 & +100 \\
\hline & & & 3 & 0 & & & & & 2 & & & & & & 5 & \\
\hline $\begin{array}{l}\text { Montmorillo } \\
\text { nite }\end{array}$ & $\begin{array}{l}\mathrm{Na}_{0.2} \mathrm{Ca}_{0.1} \mathrm{Al}_{2} \mathrm{Si}_{4} \mathrm{O}_{10}(\mathrm{OH})_{2}( \\
\left.\mathrm{H}_{2} \mathrm{O}\right)_{10}\end{array}$ & 1 & 0 & -100 & 2 & 0 & -100 & 1 & 0 & -100 & 1 & 0 & -100 & 1 & 0 & -100 \\
\hline Plagioclase & $(\mathrm{Na}, \mathrm{Ca}) \mathrm{Al}(\mathrm{Al}, \mathrm{Si}) \mathrm{Si}_{2} \mathrm{O}_{8}$ & 3 & 1 & -63 & 3 & 1 & -61 & 8 & 1 & -86 & 2 & 1 & -36 & 3 & 1 & -63 \\
\hline K-feldspar & $\mathrm{KAISi}_{3} \mathrm{O}_{8}$ & 2 & 1 & -45 & 2 & 1 & -42 & 2 & 1 & -44 & 2 & 1 & -36 & 1 & 1 & 0 \\
\hline \multirow{2}{*}{ Wollastonite } & $\mathrm{CaSiO}_{3}$ & 0 & 1 & +10 & 0 & 0 & - & 0 & 0 & - & 0 & 0 & - & 0 & 0 & - \\
\hline & & & & 0 & & & & & & & & & & & & \\
\hline \multirow[t]{2}{*}{ Melilite } & $\mathrm{Ca}_{1.5} \mathrm{Na}_{0.5} \mathrm{Al}_{1.1} \mathrm{Mg}_{0.3} \mathrm{Fe}_{0.1} \mathrm{Si}$ & 0 & 1 & +10 & 0 & 1 & +100 & 0 & 1 & +100 & 0 & 0 & - & 0 & 1 & +100 \\
\hline & ${ }_{1.5} \mathrm{O}_{7}$ & & & 0 & & & & & & & & & & & & \\
\hline \multirow[t]{2}{*}{ Magnetite } & $\mathrm{Fe}_{3} \mathrm{O}_{4}$ & 0 & 1 & +10 & 0 & 1 & +100 & 0 & 1 & +100 & 0 & 1 & +100 & 0 & 1 & +100 \\
\hline & & & & 0 & & & & & & & & & & & & \\
\hline Lime & $\mathrm{CaO}$ & 1 & 0 & -100 & 1 & 0 & -100 & 1 & 0 & -100 & 2 & 0 & -100 & 1 & 0 & -100 \\
\hline Periclase & $\mathrm{MgO}$ & 1 & 0 & -100 & 1 & 0 & -100 & 1 & 0 & -100 & 1 & 0 & -100 & 1 & 0 & -100 \\
\hline Hematite & $\mathrm{Fe}_{2} \mathrm{O}_{3}$ & 6 & 3 & -45 & 6 & 2 & -61 & 8 & 1 & -86 & 7 & 1 & -82 & 5 & 2 & -56 \\
\hline Corundum & $\mathrm{Al}_{2} \mathrm{O}_{3}$ & 2 & 1 & -45 & 0 & 0 & -100 & 1 & 0 & -100 & 0 & 0 & - & 0 & 0 & - \\
\hline Anhydrite & $\mathrm{CaSO}_{4}$ & 3 & 1 & -63 & 4 & 1 & -71 & 8 & 1 & -86 & 4 & 1 & -68 & 4 & 1 & -72 \\
\hline Siderite & $\mathrm{FeCO}_{3}$ & 1 & 0 & -100 & 1 & 0 & -100 & 1 & 0 & -100 & 1 & 0 & -100 & 1 & 0 & -100 \\
\hline Calcite & $\mathrm{CaCO}_{3}$ & 11 & 0 & -100 & 3 & 0 & -100 & 5 & 0 & -100 & 3 & 0 & -100 & 17 & 0 & -100 \\
\hline Dolomite & $(\mathrm{Ca}, \mathrm{Mg}) \mathrm{CO}_{3}$ & 1 & 0 & -100 & 2 & 0 & -100 & 2 & 0 & -100 & 2 & 0 & -100 & 1 & 0 & -100 \\
\hline Ankerite & $\mathrm{Ca}(\mathrm{Fe}, \mathrm{Mg}) \mathrm{CO}_{3}$ & 1 & 0 & -100 & 2 & 0 & -100 & 1 & 0 & -100 & 1 & 0 & -100 & 1 & 0 & -100 \\
\hline
\end{tabular}


Appendix 5.D Thermodynamic equilibrium results

The designation "SALTA" in the figures indicates that it is a molten salt constituent.
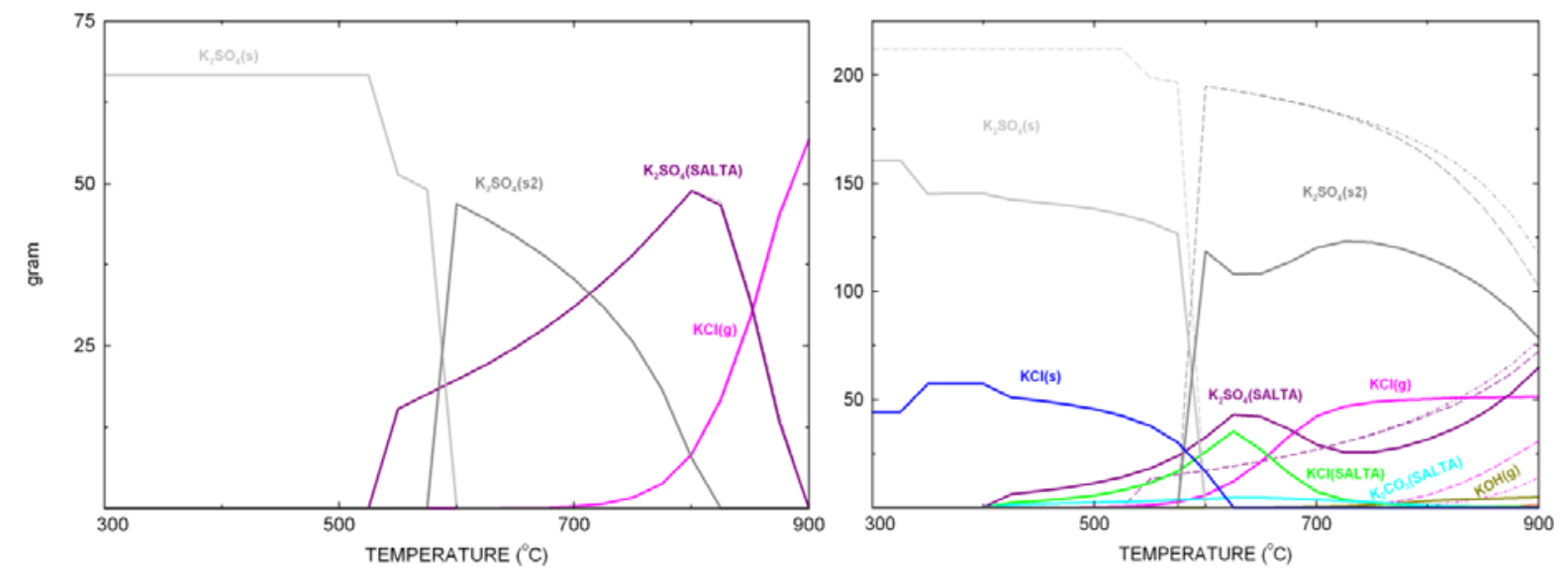

Figure 5.D.1 Thermodynamic equilibrium diagrams with different amounts of $\left(\mathrm{NH}_{4}\right)_{2} \mathrm{SO}_{4}$ addition ( $\quad 0 \mathrm{~g} \mathrm{MJ}^{-1}$, - - - $0.1 \mathrm{~g} \mathrm{MJ}^{-1}$ and -.-.- $1 \mathrm{~g} \mathrm{MJ}^{-1}$ addition); K-containing compounds. Left: $100 \%$ MBM-mix. Right: $100 \%$ wood.
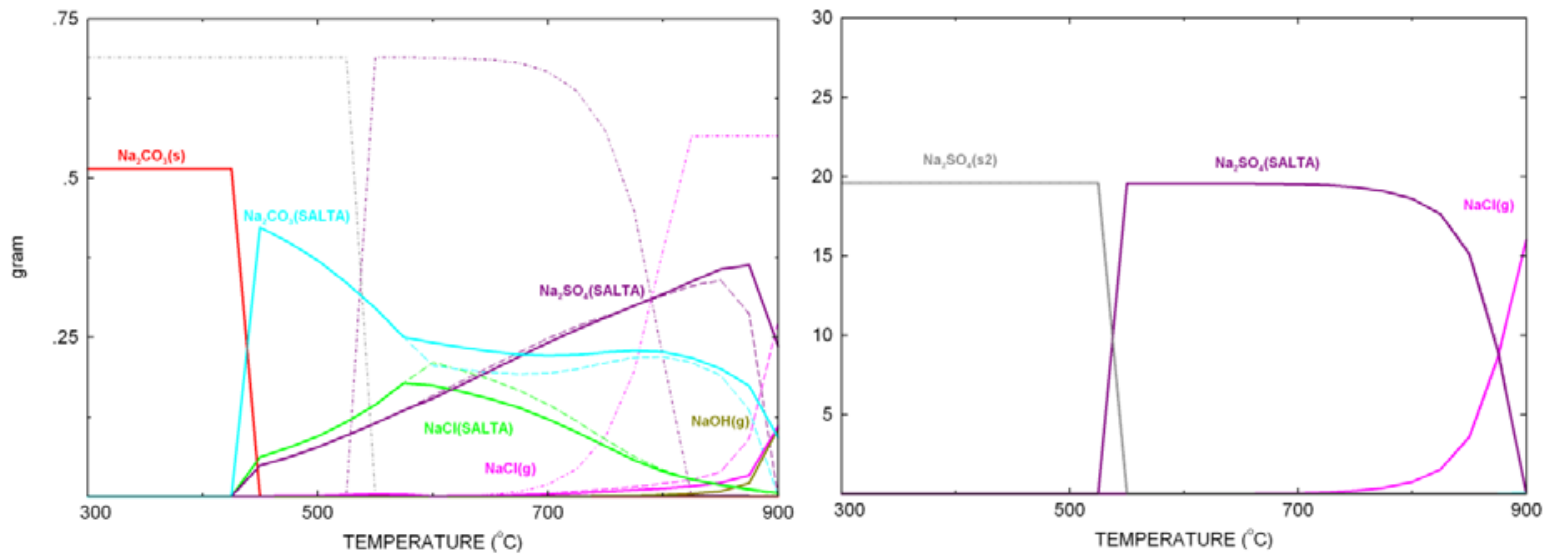

Figure 5.D.2 Thermodynamic equilibrium diagrams with different amounts of $\left(\mathrm{NH}_{4}\right)_{2} \mathrm{SO}_{4}$ addition ( $0 \mathrm{~g} \mathrm{MJ}^{-1}$, - - - $0.1 \mathrm{~g} \mathrm{MJ}^{-1}$ and -..- $1 \mathrm{~g} \mathrm{MJ}^{-1}$ addition); Na-containing compounds. Left: $100 \%$ sheanut-mix. Right: $100 \%$ MBM-mix. 

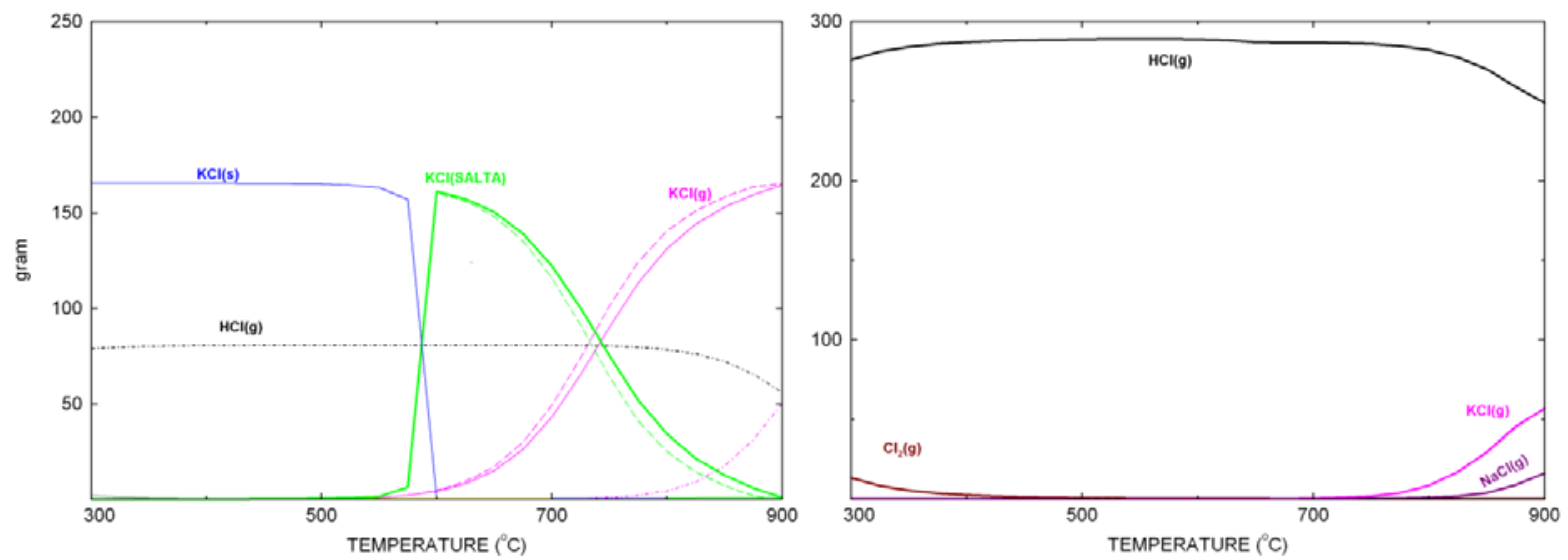

Figure 5.D.3 Thermodynamic equilibrium diagrams with different amounts of $\left(\mathrm{NH}_{4}\right)_{2} \mathrm{SO}_{4}$ addition ( $0 \mathrm{~g} \mathrm{MJ}^{-1}$, - - $0.1 \mathrm{~g} \mathrm{MJ}^{-1}$ and -.-.- $1 \mathrm{~g} \mathrm{MJ}^{-1}$ addition); Cl-containing compounds. Left: $100 \%$ sheanut-mix. Right: 100\% MBM-mix.

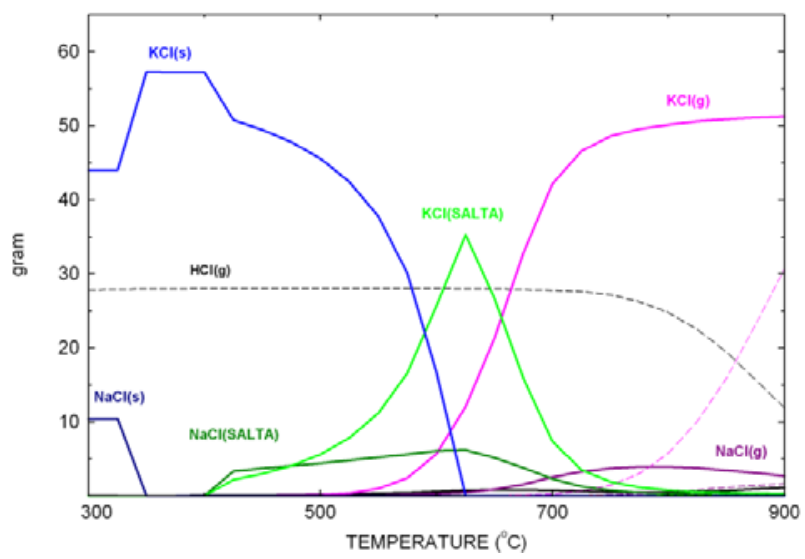

Figure 5.D.4 Thermodynamic equilibrium diagrams with different amounts of $\left(\mathrm{NH}_{4}\right)_{2} \mathrm{SO}_{4}$ addition ( $\_\mathrm{g} \mathrm{MJ}^{-1}$, - - $0.1 \mathrm{~g} \mathrm{MJ}^{-1}$ and -...- $1 \mathrm{~g} \mathrm{MJ}^{-1}$ addition); Cl-containing compounds. $100 \%$ wood. 


\section{Appendix to chapter 7}

Appendix 7.A Cr analyses

Table 7.A.1 Cr(VI) analyses of bottom and fly ashes from pf boilers

\begin{tabular}{|c|c|c|c|c|c|c|}
\hline coal & secondary fuel & $\begin{array}{l}\text { co-firing } \\
\%\end{array}$ & $\begin{array}{l}\text { type of } \\
\text { sample* }^{*}\end{array}$ & $\begin{array}{l}\mathrm{Cr}_{\text {tot }} \\
\mathrm{ppm}\end{array}$ & $\begin{array}{l}\mathrm{Cr}(\mathrm{VI}) / \\
\mathrm{Cr}_{\text {total }}(\%)\end{array}$ & $\begin{array}{l}\text { leachable } \\
\mathrm{Cr}(\mathrm{mg} / \mathrm{kg})\end{array}$ \\
\hline blend & \multirow{7}{*}{ none } & \multirow{7}{*}{0} & PFA & 171 & 6 & 6.2 \\
\hline blend & & & PFA-C & 150 & 6 & 3.8 \\
\hline blend & & & PFA-5 & 1650 & 8 & \\
\hline blend & & & PFA-C & 136 & 7 & \\
\hline blend & & & BA & 110 & 5 & \\
\hline blend & & & PFA-C & 144 & 6 & 5.9 \\
\hline blend & & & PFA-4 & 174 & 9 & \\
\hline blend & \multirow{3}{*}{ MBM, biomass mix } & 7 & PFA-C & 130 & 4 & \\
\hline blend & & 7 & PFA-5 & 180 & 2 & \\
\hline blend & & 9 & PFA-C & 120 & 3 & 1.1 \\
\hline blend & \multirow{3}{*}{$\begin{array}{l}\text { MBM, biomass } \\
\text { mix, wood, cacao } \\
\text { residue }\end{array}$} & \multirow{3}{*}{18} & $\mathrm{BA}$ & 88 & 2 & 0.6 \\
\hline blend & & & $\begin{array}{l}\mathrm{PFA}< \\
\text { deNOx** }\end{array}$ & 149 & 4 & \\
\hline blend & & & PFA-C & 139 & 4 & 2.5 \\
\hline Polish & $\begin{array}{l}\text { municipal sewage } \\
\text { sludge }\end{array}$ & 10 & PFA-C & 186 & 4 & 1.0 \\
\hline blend & \multirow{4}{*}{$\begin{array}{l}\text { sheanut, palm } \\
\text { kernel, cacao }\end{array}$} & \multirow{4}{*}{21} & PFA-1 & 182 & 6 & 2.0 \\
\hline blend & & & PFA-2 & 181 & 6 & \\
\hline blend & & & PFA-3 & 228 & 6 & \\
\hline blend & & & PFA-4 & 224 & 6 & \\
\hline blend & \multirow{3}{*}{ wood } & 7 & PFA-C & 166 & 16 & 15 \\
\hline blend & & 15 & PFA-C & 177 & 13 & 15 \\
\hline blend & & 28 & PFA-C & 182 & 12 & \\
\hline
\end{tabular}


Table 7.A.2 Cr(VI) analyses of fly ash from CFB

\begin{tabular}{|c|c|c|c|c|c|}
\hline Coal & secondary fuel & $\begin{array}{l}\text { biomass } \\
(\%)\end{array}$ & $\begin{array}{l}\text { type of } \\
\text { sample* }\end{array}$ & $\begin{array}{l}\text { Crtot } \\
\text { ppm }\end{array}$ & $\begin{array}{l}\% \\
\mathrm{Cr}(\mathrm{VI})\end{array}$ \\
\hline \multirow{2}{*}{ none } & municipal sewage & & CFB filter & & \\
\hline & sludge & 100 & ash & 135 & 4 \\
\hline \multirow{3}{*}{ none } & \multirow{4}{*}{ pruning, wood } & & BFB filter & & \\
\hline & & 100 & ash & 123 & 29 \\
\hline & & & BFB & & \\
\hline none & & 100 & ash & 90 & 41 \\
\hline
\end{tabular}

${ }^{*}$ CFB = Circulating Fluidized Bed; BFB = bubbling fluidized bed.

Table 7.A.3 Cr(VI) analyses of fly ash from gasifiers

\begin{tabular}{|c|c|c|c|c|c|}
\hline coal & secondary fuel & $\begin{array}{l}\text { co-firing } \\
\%\end{array}$ & $\begin{array}{ll}\text { type } & \text { of } \\
\text { sample* }^{*} & \end{array}$ & $\begin{array}{l}\text { Crtot } \\
\text { ppm }\end{array}$ & $\begin{array}{l}\% \\
\mathrm{Cr}(\mathrm{VI})\end{array}$ \\
\hline SAf/Col & none & 0 & CG-fly ash & 166 & 0 \\
\hline Colombian & none & 0 & CG-fly slag & 128 & 0 \\
\hline Colombian & none & 0 & CG-fly ash & 123 & 0 \\
\hline \multirow[t]{2}{*}{ Colombian } & wood & 20 & CG-fly ash & 103 & 0 \\
\hline & demolition & & BFBG & & \\
\hline none & wood & 100 & cyclone ash & 311 & 3 \\
\hline
\end{tabular}



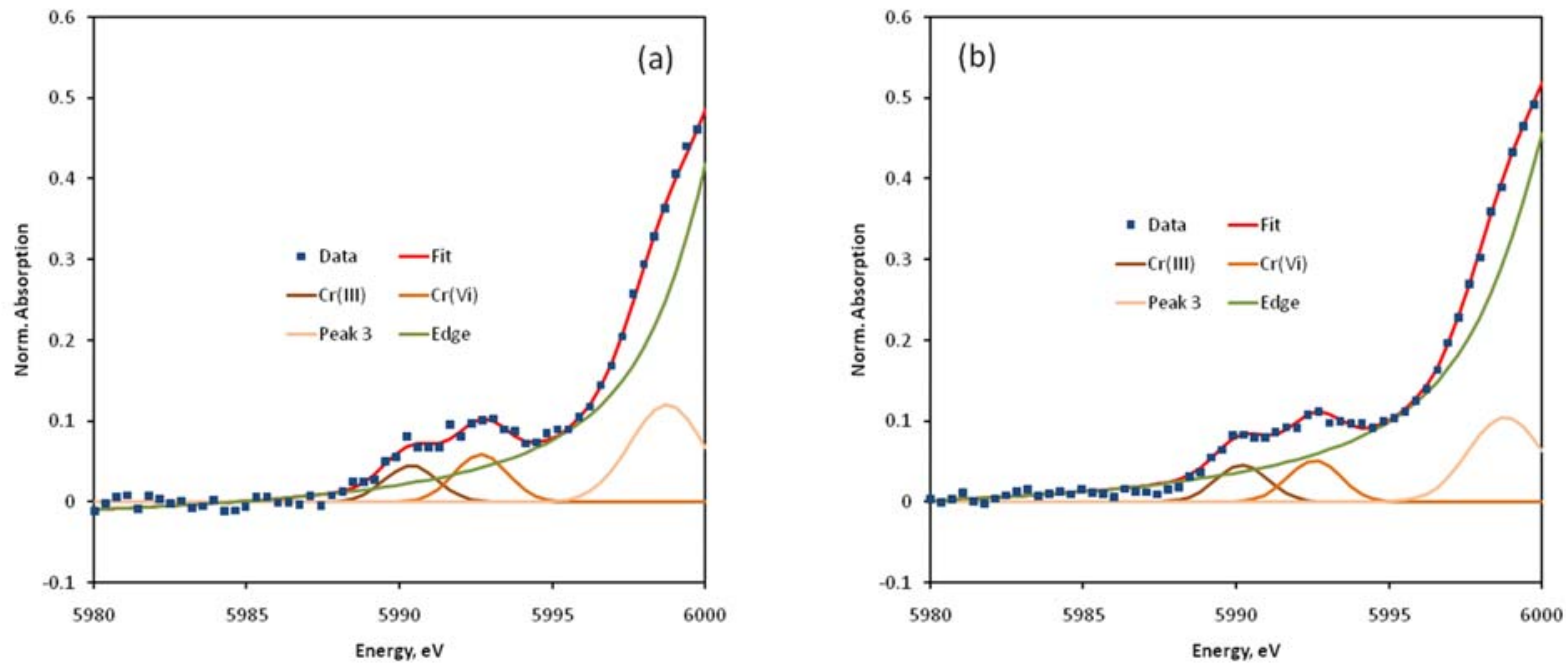

Figure 7.A.1 XANES spectra of bottom ash (a) and fly ash (b) (PF-BA and PFA-C) resulting from $18 \%$ co-firing of MBM-mix with coal. 
Appendix 7.B Details on thermodynamic calculations

Table 7.B.1 Details on thermodynamic calculations (input)

\begin{tabular}{|c|c|c|c|c|c|c|c|}
\hline & $\begin{array}{l}\text { coal } \\
\text { sheanut }\end{array}$ & $\begin{array}{l}+21 \% \\
\operatorname{mix}\end{array}$ & $\begin{array}{l}\text { coal + } \\
\operatorname{mix}\end{array}$ & $18 \% \mathrm{MBM}$ & $\begin{array}{l}\text { coal } \\
\text { wood }\end{array}$ & $+7-28 \%$ & coal \\
\hline & coal & sec. fuel & coal & sec. fuel & coal & sec. fuel & coal \\
\hline $\mathrm{C}(\%)$ & 70.4 & 47.84 & 73.0 & 45.10 & 67.41 & 50.60 & 71.05 \\
\hline $\mathrm{H}(\%)$ & 3.9 & 3.95 & 4.6 & 6.11 & 4.81 & 5.98 & 4.61 \\
\hline$N(\%)$ & 1.7 & 2.42 & 1.6 & 8.82 & 1.45 & 0.10 & 1.50 \\
\hline $\mathrm{S}(\%)$ & 0.2 & 0.22 & 0.4 & 0.49 & 0.24 & 0.01 & 0.69 \\
\hline $\mathrm{O}(\%)$ & 8.9 & 39.21 & 7.2 & 20.15 & 12.41 & 42.92 & 9.83 \\
\hline total water $(\%)$ & 6.9 & 2.24 & 9.0 & 4.12 & 9.86 & 5.20 & 9.95 \\
\hline Ash (\%) & 14.6 & 6.35 & 12.8 & 18.70 & 13.4 & 0.46 & 12.30 \\
\hline LHV (MJ/kg) & 25.2 & 18.17 & 25.2 & 17.67 & 24.91 & 18.34 & 25.21 \\
\hline $\mathrm{Al}(\%)$ & 1.47 & 0.05 & 1.19 & 0.01 & 1.35 & 0.00 & 1.08 \\
\hline $\mathrm{Ca}(\%)$ & 0.41 & 0.20 & 0.20 & 3.46 & 0.24 & 0.06 & 0.21 \\
\hline $\mathrm{Cl}(\%)$ & 0.0041 & 0.1050 & 0.0231 & 0.5840 & 0.0027 & 0.0110 & 0.0103 \\
\hline $\mathrm{Fe}(\%)$ & 0.24 & 0.17 & 0.34 & 0.11 & 0.19 & 0.00 & 0.36 \\
\hline $\mathrm{K}(\%)$ & 0.04 & 1.87 & 0.09 & 0.71 & 0.04 & 0.05 & 0.08 \\
\hline $\mathrm{Mg}(\%)$ & 0.10 & 0.30 & 0.06 & 0.08 & 0.08 & 0.01 & 0.09 \\
\hline $\mathrm{Na}(\%)$ & 0.01 & 0.01 & 0.03 & 0.46 & 0.02 & 0.00 & 0.03 \\
\hline $\mathrm{P}(\%)$ & 0.06 & 0.36 & 0.03 & 1.86 & 0.03 & 0.00 & 0.03 \\
\hline Si (\%) & 2.04 & 0.27 & 1.87 & 0.06 & 1.90 & 0.01 & 1.76 \\
\hline $\mathrm{Ti}(\%)$ & 0.09 & 0.00 & 0.09 & 0.00 & 0.13 & 0.00 & 0.07 \\
\hline $\mathrm{Cr}(\mathrm{ppm})$ & 31.0 & 4.74 & 22.5 & 6.55 & 22.0 & 0.23 & 24 \\
\hline
\end{tabular}

Indicated are the fuels as considered for input for the calculations. The relative input of coal and secondary fuel is based on the thermal heat input. Air is considered with the fuel for different equivalence ratio's $(\lambda)$ of which typical considered values are $0.8,1$ and 1.16 . 
Table 7.B.2 Details on thermodynamic calculations (output selection)

\begin{tabular}{|c|c|}
\hline $\begin{array}{l}\text { gaseous } \\
\text { compounds }\end{array}$ & 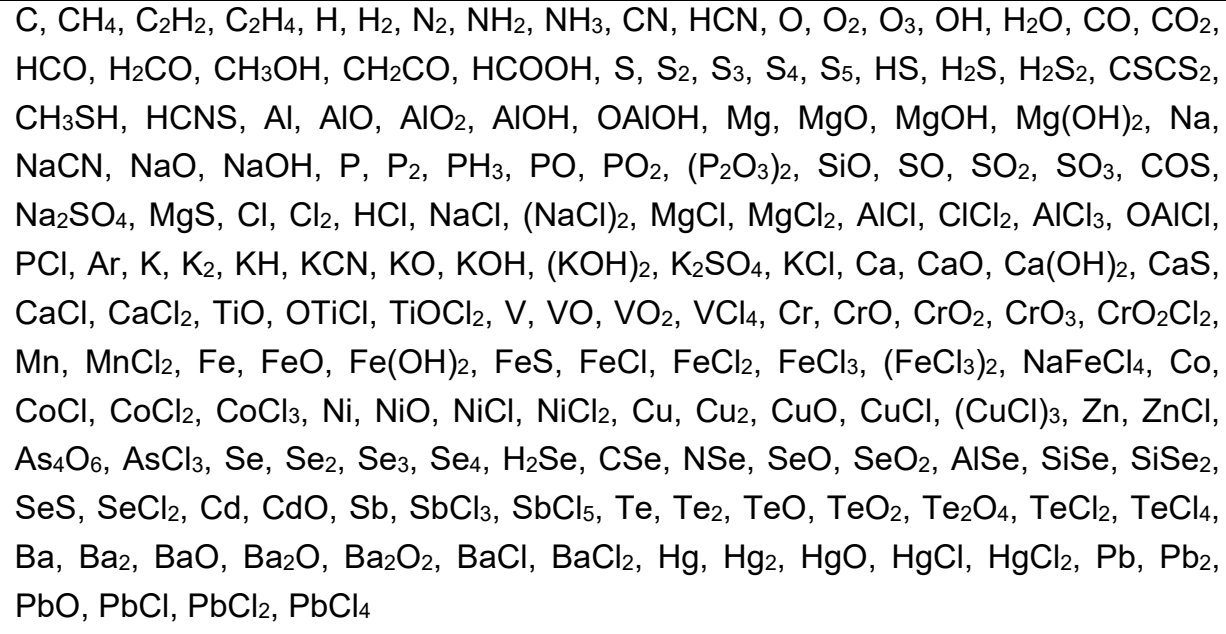 \\
\hline $\begin{array}{l}\text { solid } \\
\text { compounds }\end{array}$ & 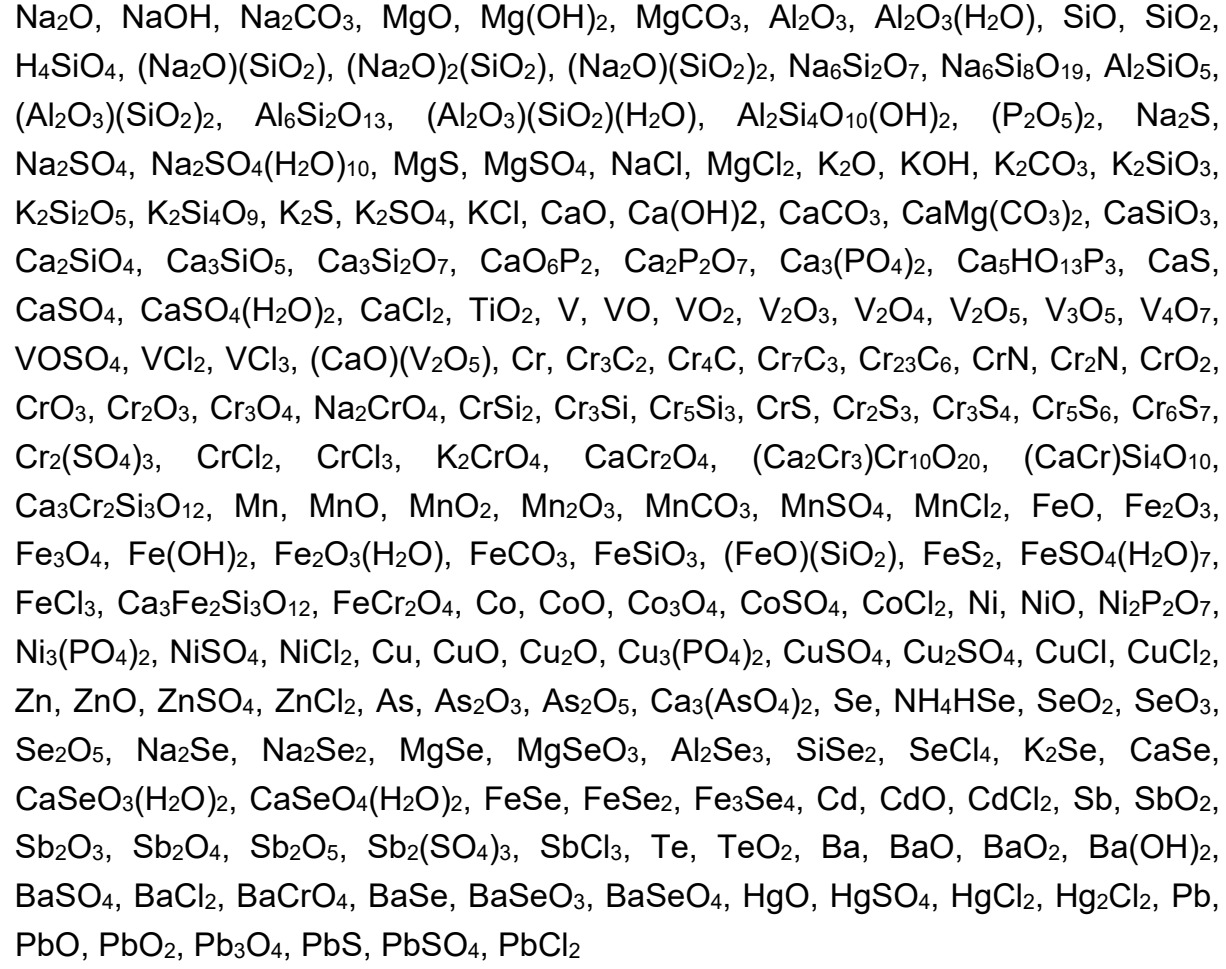 \\
\hline $\begin{array}{l}\text { solution } \\
\text { phases }\end{array}$ & SLAGD , SLAGE , SLAGF \\
\hline
\end{tabular}




\title{
NOMENCLATURE
}

\author{
a.r. as received \\ ASTM American Society for Testing and Materials. \\ BA Bottom Ash \\ BE Backscatter Electron \\ BEI Backscatter Electron Image \\ BFB Bubbling Fluidized Bed \\ BFBG Bubbling Fluidized Bed Gasifier \\ CCS Carbon Capture and Storage \\ CCSEM Computer-Controlled Scanning Electron Microscopy \\ CF Chemical Fractionation \\ CFB Circulating Fluidized Bed \\ CFD Computational Fluid Dynamics \\ CG Coal Gasification \\ d.a.f. dry ash free \\ EDS Energy Dispersive X-ray Spectroscopy \\ EDX Energy Dispersive X-ray Spectroscopy \\ ESP ElectroStatic Precipitator \\ EWC European Waste Catalogue \\ EXAFS Extended X-ray Absorption Fine-structure Spectroscopy \\ FA Fly Ash \\ FBC Fluidized Bed Combustion \\ FGET Furnace Gas Exit Temperature \\ HTA High Temperature Ashing \\ ICP Inductive Coupled Plasma \\ IPCC Intergovernmental Panel on Climate Change \\ LHV Lower Heating Value
}




$\begin{array}{ll}\text { LOWESS } & \text { Locally WEighted Scatterplot Smoothing } \\ \text { L/S } & \text { Liquid to Solid (ratio) } \\ \text { MBM } & \text { Meat and Bone Meal } \\ \text { MBMS } & \text { Molecular Beam Mass Spectrometry } \\ \text { OFA } & \text { Over Fire Air } \\ \text { pC } & \text { pulverized coal } \\ \text { pf } & \text { pulverized fuel } \\ \text { PFA } & \text { pulverized fuel fly ash } \\ \text { PID } & \text { proportional, integral, derivative } \\ \text { PSD } & \text { Particle Size Distribution } \\ \text { PRB } & \text { Powder River Basin } \\ \text { SE } & \text { Secondary Electron } \\ \text { SEI } & \text { Secondary Electron Image } \\ \text { SEM } & \text { Scanning Electron Microscopy } \\ \text { RE } & \text { Relative Enrichment } \\ \text { XANES } & \text { X-ray Absorption Near-Edge Spectroscopy } \\ \text { XAFS } & \text { X-ray Absorption Fine Structures } \\ \text { XRD } & \text { X-Ray Diffraction } \\ \text { XRF } & \text { X-Ray Fluorescence } \\ \end{array}$




\section{ACKNOWLEDGEMENTS}

First of all, l'd like to thank my promotor Prof. dr. ir. Gerrit Brem for our fruitful discussions and his encouragement. Special thanks to dr. ir. Ton Konings for your valuable advice and significant time spent on reviewing my research and motivating me to keep going.

This Thesis started as a request from a joint request of the Dutch power generating companies, represented by dr. Bart Dijkman. A special thanks these companies Electrabel, E.ON, EPZ, Essent and NUON for providing funding. The request was put into practise by dr. Nanno Bolt arranging a AIO position at University of Twente. Dr. Ruud Meij encouraged me to take up this position. Additional funding was obtained from the European Union, through the project NextGenPower. This project could not have started without the inspiring tips of dr. Kees van den Ende, the unrelenting effort of ir. Paul Welberg and the great helps of Prof. John Oakey. In addition, Ing. Kees Haasnoot provided me with the challenge of analysing the fouling problems at the CFB in Cuijk. Thanks to all!

A part of this Thesis is based on experimental work in power plants. A special thanks to Ing. Martin de Jong, Ing. Remco Bosgraaf, dr. Bill Cox and Adrian Metcalfe assisting me with that. And of course none of the work would have been possible without the support of the people at the Maasvlakte plant: Ing. Cees Korevaar, Eric Boender and Ing. Kurt Stam, and the Amer plant: dr. Wim Willeboer and ir. Emiel Van Dorp. All samples resulting from the trials have been prepared by Ing. René Leferink, who also assisted with the SEM investigations and the preparation of the SEM results. Again, thanks to all!

Furthermore, l'd like to thank dr. Bill Livingston and dr. Marcel Cremers for contributing to the review paper for the IEA. Thanks to Prof. dr. Frank Huggins for your valuable advice and for performing the XAFS analyses. Thanks to dr. Ronald van Eijk and Ing Henk te Winkel for your contribution on the $\mathrm{Cr}(\mathrm{VI})$ work; Henk, may you rest in piece. Thanks again to all the co-authors already mentioned before. Taha, thanks for your work on the combustion model and the implementation of my models in a CFD model: although it didn't lead to a chapter in this thesis, it provided me with a profound understanding of the modelling work.

I've had several technical discussions, advice on microscopy and modelling as well as review of concepts of parts of this thesis as well as a lot of encouragement by dr. ir. Klaas Agema and dr. dipl.-ing. Markus Schmitt. Klaas, Markus, thanks!

Last, but not least, my special thanks go to Desirée, my parents and friends for your everlasting support. 


\section{CURRICULUM VITAE}

The author Arthur Frank Stam was born on May 12, 1980 in Nijmegen, The Netherlands. After he obtained his Master's Degree in mechanical engineering at Delft University of Technology, he started working at KEMA. First he worked as a researcher on trace element speciation in combustion by-products and later as a technical consultant in the field of corrosion, slagging and fouling. After working as a project manager of the EU-project NextGenPower, he's currently employed as a business development manager for mechanized Non-Destructive Testing at DEKRA. 


\section{PUBLICATIONS}

Publications related to this thesis:

Stam AF, Brem G. Fouling in coal-fired boilers: Biomass co-firing, full conversions and use of additives - A thermodynamic approach. Fuel, 2019, 239, 1274-83.

Stam AF, Haasnoot K, Brem G. Superheater fouling in a BFB boiler firing wood-based fuel blends. Fuel 2014; 135:322-31.

Taha TJ, Stam AF, Stam K, Brem G. CFD modeling of ash deposition for co-combustion of MBM with coal in a tangentially fired utility boiler. Fuel Proc Technol, 2013, 114, 126-34.

Stam AF, Huggins FE. Estimating $\mathrm{Cr}(\mathrm{VI})$ in Coal-Derived Fly ash. Science Highlight, Stanford University, Stanford Synchrotron Radiation Lightsource, Jun 01, 2011.

Stam AF, Meij R, Te Winkel BH, Van Eijk RJ, Huggins FE, Brem G. Chromium Speciation in Coal and Biomass Co-Combustion Products, Env Sci Techn, 2011, 45, 2450-6.

Stam AF, Ploumen P, Brem G. Ash related aspects of oxy-combustion of coal and biomass: a thermodynamic approach. International Conference on Coal Utilization \& Fuel systems, Clearwater, USA, Jun 04, 2009.

Stam AF, Livingston WR, Cremers MFG, Brem G, Review of models and tools for slagging and fouling prediction for biomass co-combustion. IEA Task 32,Jan 01, 2009.

Stam AF, Brem G. Slagging Prediction of slagging with enhanced biomass co-firing in Dutch utility boilers using an engineering method. International Conference on Coal Utilization \& Fuel systems, Clearwater, USA, Jun 06, 2008.

Stam AF, Van Eijk RJ, Te Winkel BH. Environmental and health aspects of coal and biomass cocombustion ashes, World Of Coal Ash (WOCA) conference, Denver, USA, May 01, 2011.

Stam AF, Van Eijk RJ Cieplik MK. Effects of biomass co-firing on speciation and availability of trace elements. International Conference on Coal Utilization \& Fuel systems, Clearwater, USA, Jun 04, 2009.

Stam AF, Meij R, Te Winkel BH, Cieplik M. Predictions of the speciation of elements in coal ash with thermodynamic equilibrium calculations for advanced techniques in pf-coal-fired power plants co-firing biomass, 32nd International Conference on Coal Utilization \& Fuel systems, Clearwater, USA, Jun 15, 2007. 
Other selected publications:

Stam AF, Van der Gun S, Raas H, Van den Bos A. Corrosion in blast furnace gas fired power plants. Presented at BALTICA X, June 2016.

Stam AF. NextGenPower - A European project researching and demonstrating $\mathrm{Ni}$-alloys for application in power plants operating at $750^{\circ} \mathrm{C}$ steam temperature. 10th Liège Conference on Materials for Advanced Power Engineering

Stam AF. NextGenPower - Demonstration and component fabrication of nickel alloys and protective coatings for steam temperatures of $750^{\circ} \mathrm{C}$. Presented at the Seventh International Conference on Advances in Materials Technology for Fossil Power Plants, October 22 - 25 , 2013, Waikoloa, Hawaii, USA.

Stam AF, Raats PH, De Wolff JJ, Follmann PM, NanoGLOWA: Nano-structered membranes against global warming, POWER-GEN Europe Conference, Jun 06, 2008. 